\title{
Final Technical Report for Resource Confirmation Testing at the Raft River Geothermal Project, Cassia County, Idaho
}

DOE Award Number: DE-FC36-02AL68229

Recipient:

Project Title:

Project Director:

Team Members:
US Geothermal Inc.

Resource Confirmation Testing \& Demo of Generating Capacity, Raft River Project

Douglas Glaspey

Kevin Kitz, US Geothermal Inc; Doug Crea US Geothermal Inc;

Bill Teplow; Subir Sanyal, Geothermex Inc; David Faulder, SAIC 


\section{Executive Summary}

A Department of Energy “Financial Assistance Award” allowed U.S. Geothermal Inc. to sufficiently define the reservoir parameters at the Raft River geothermal project in Cassia County, Idaho to complete the first; privately owned, commercial, geothermal power plant in the State.

The Raft River geothermal project was originally developed by the Department of Energy as a demonstration of the viability of the geothermal resource and of binary cycle power plant technology. Five production wells and two injection wells were drilled which were used to operate a 5 MW power plant. In 2002 the property was acquired by U.S. Geothermal Inc. for commercial geothermal development. Late that year U.S. Geothermal Inc. was granted a "Financial Assistance Award" from the DOE to test the existing geothermal wells in order to assess and define the geothermal resource.

In compliance with the statement of objectives of the "Financial Assistance Award", flow and pressure build-up tests were conducted and analyzed on five existing geothermal wells at Raft River. Based on the results of those tests U.S. Geothermal initiated a six well drilling program in 2006 in an effort to obtain enough injection and production capacity to operate a 13 MW power plant. Two wells (RRGI-6 and RRGI-7) were deepened, two wells (RRGI-3 and RRGI-4) had new legs drilled to increase productivity, and two wells (RRGI-9 and RRGI-11) were drilled as new grass roots wells.

Analysis of additional flow, pressure build-up, and interference testing performed on some of the new and modified wells showed that there was sufficient capacity to complete the construction of a 13 MW, binary cycle power plant. U.S. Geothermal's Raft River Unit One power plant construction was completed in the fall of 2007, followed by initial startup and testing. The power plant went into commercial operation in January 2008 demonstrating the commercial feasibility of deeper, lower temperature geothermal resources in the western United States. 


\section{Objectives, Accomplishments, Activities}

When U.S. Geothermal acquired the Raft River Geothermal project in 2002, five production wells and two injection wells had been drilled and extensively tested by DOE in the late 1970's and early 1980's. However, the wells had been shut-in since that time; the condition and capacities of the wells after such a long period of inactivity was unknown.

The production zones from the Raft River wells were known to be deep (greater than $5000 \mathrm{ft}$.) and relatively low temperature (less than 300 degrees F). It was uncertain whether deep, low temperature geothermal wells could be economically developed for electrical power generation. Therefore the objectives stated in the application for the "Financial Assistance Award" were:

1) To test and assess the existing wells in order to define the geothermal resource.

2) To demonstrate that even deep, low temperature fields can be developed commercially in the western United States.

A testing and assessment program for the existing production wells was implemented in 2004. Flow and pressure build-up tests were conducted on all five existing production wells. The interpretation of the results of those tests was done by GeothermEx, Inc. and their detailed findings can be found in the section of this report entitled "Results from the Short-Term Well Testing Program at the Raft River Geothermal Field, Cassia Count, Idaho.” The first objective was met upon completion of this report. However, to meet the second objective an investment decision needed to be made. It was decided that the results of the testing program were encouraging enough to justify the investment of millions of dollars in a drilling program to expand the resource sufficiently for commercial development.

The expansion drilling program was initiated in August 2006 and completed in May 2007. During the program well RRGI-7 was deepened and converted from an injection well to a production well. Well RRGI-6 was deepened and retained as an injection well. The original leg of production well RRGI-4 was plugged off and a side track drilled. Well RRGI-3 was converted from a production well to an injection well by deepening the original leg and then drilling a second leg.

Wells RRGI-9 and 11 were drilled as grassroots wells. Well RRGI-11 was drilled with two legs and completed as an injection well. Well RRGI-9 was drilled with one leg and completed as a spare injection well.

An interference testing program was conducted in March 2007 which confirmed that sufficient production and injection capacity was available to supply a $13 \mathrm{MW}$ binary power plant. The detailed results of the interference test were preformed by SAIC, Inc. and can be found in the section of this report entitled "RRG-4 Flow and Pressure Build-up Test." 
Concurrently with the drilling program, construction of a $13 \mathrm{MW}$ binary power plant was started and construction was completed in the fall of 2007. Initial startup and testing followed completion and the power plant went into commercial operation in January 2008. Commercial operation of the power plant met the second objective of the "Financial Assistance Award."

In summary, both objectives of the "Financial Assistance Award" were met in the manner and using the techniques and activities originally envisioned. Although no new products or technologies were developed with this award, the major goal of demonstrating the commercial feasibility of power generation from deep, low temperature geothermal resources in the western United States was accomplished. 
RESULTS FROM THE SHORT-TERM WELL TESTING PROGRAM AT THE RAFT RIVER GEOTHERMAL FIELD, CASSIA COUNTY, IDAHO 


\section{CONTENTS}

2. DATA ANALYSIS METHODOLOGY

2.1 Power Available from the Fluid

2.2 Initial Well Productivity

2.3 Decline in Well Productivity with Time and due to Well Interference

2.4 Analysis of Flow Test and Pressure Build-up Data

3. RESULTS OF FLOW AND PRESSURE BUILD-UP TESTS

3.1 Initial Well Productivity

3.2 Initial Power Capacity $3-2$

3.3 Analysis of Pressure Build-up Data $3-2$

3.4 Forecast of Power Capacity Decline $3-3$

3.5 Sustainable Plant Capacity $3-4$

4. RESULTS OF FLUID SAMPLING AND ANALYSIS …….................................... 4-1

4.1 Sample Collection, Analyses and Reporting ..................................................... 4-1

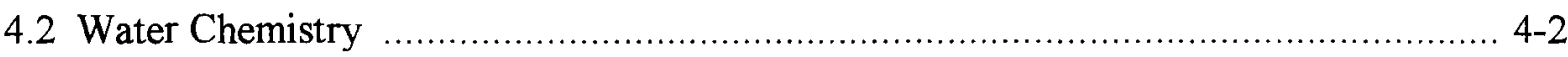

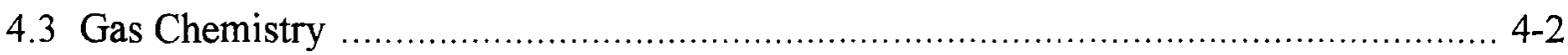

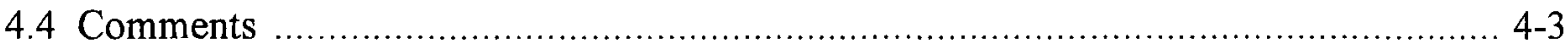

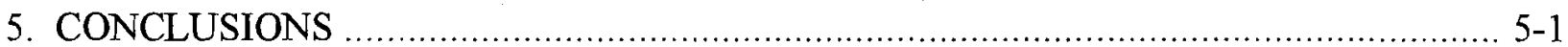

\section{TABLES}

FIGURES 


\section{ILLUSTRATIONS}

Tables

3.1 Pump Calculations for Well RRG-1

3.2 Pump Calculations for Well RRG-2

3.3 Pump Calculations for Well RRG-3

3.4 Pump Calculations for Well RRG-5

3.5 Results of Pressure Build-up Data Analysis

4.1 Chemical Analyses of Water Samples from Raft River Well Tests 2004

4.2 Aqueous Geothermometry of Samples from Raft River - Tests of 2004

4.3 Raft River - Analyses of Gases in Steam

$\underline{\text { Figures }}$

1.1 Production rate and pressure data - Well RRG-1

1.2 Production rate and temperature data - Well RRG-1

1.3 Production rate and pressure data - Well RRG-2

1.4 Production rate and temperature data - Well RRG-2

1.5 Production rate and pressure data - Well RRG-3

1.6 Production rate and temperature data - Well RRG-3

1.7 Production rate and pressure data - Well RRG-4

1.8 Production rate and temperature data - Well RRG-4

1.9 Production rate and pressure data - Well RRG-5

1.10 Production rate and temperature data - Well RRG-5 
1.11 Downhole summary plot - Raft River well RRG-1

1.11A Explanation for downhole summary plots

1.12 Downhole summary plot - Raft River well RRG-2

1.13 Downhole summary plot - Raft River well RRG-3

1.14 Downhole summary plot - Raft River well RRG-4

1.15 Downhole summary plot - Raft River well RRG-5

1.16 Static pressure vs. depth of production level of wells

2.1 Calculated fluid requirement vs. resource temperature

3.1 Well RRG-1 - power capacity vs. pump setting depth

3.2 Well RRG-2 - power capacity vs. pump setting depth

3.3 Well RRG-3 - power capacity vs. pump setting depth

3.4 Well RRG-5 - power capacity vs. pump setting depth

3.5 Pressure build-up data match (Cartesian coordinates) Well RRG-1

3.6 Pressure build-up data match (log-log plot) Well RRG-1

3.7 Pressure build-up data match (Cartesian coordinates) Well RRG-2

3.8 Pressure build-up data match (log-log plot) Well RRG-2

3.9 Pressure build-up data match (Cartesian coordinates) Well RRG-3

3.10 Pressure build-up data match (log-log plot) Well RRG-3

3.11 Pressure build-up data match (Cartesian coordinates) Well RRG-4

3.12 Pressure build-up data match (log-log plot) Well RRG-4

3.13 Pressure build-up data match (Cartesian coordinates) Well RRG-5

3.14 Pressure build-up data match (log-log plot) Well RRG-5 
3.15 Well RRG-1 - Flow rate vs. pump setting depth

3.16 Well RRG-1 - net power capacity vs. pump setting depth

3.17 Well RRG-2 - Flow rate vs. pump setting depth

3.18 Well RRG-2 - net power capacity vs. pump setting depth

3.19 Well RRG-3 - Flow rate vs. pump setting depth

3.20 Well RRG-3 - net power capacity vs. pump setting depth

3.21 Well RRG-5 - Flow rate vs. pump setting depth

3.22 Well RRG-5 - net power capacity vs. pump setting depth

3.23 Capacity Available from Existing Wells vs. Time 


\section{DATA COLLECTION AND PROCESSING}

Preparation for and execution of the production tests, and collection of test data, were carried out by U.S. Geothermal. GeothermEx personnel were on site during the entire test of well RRG-4 only, and assisted in the direction and data collection. GeothermEx personnel were on site during the entire flow portion of the tests conducted for RRG-3 and RRG-5, but were not present when the downhole tool was run or retrieved.

The production-testing set-up included:

- a flow tee installed on the wellhead above the master valve;

- a lubricator (to allow downhole tools to be run) on the wellhead;

- a flow line, consisting of flanged line pipe and a control valve, with ports for chemical sampling and measurement of temperature and pressure installed upstream and downstream of the valve;

- a separator/silencer (of low-emission atmospheric metering separator, or LEAMS, design);

- a weirbox, with a $90^{\circ} \mathrm{V}$-notch weir.

Fluid produced during each test was piped from the weirbox to the existing drilling sump adjacent to the well pad.

The test procedure for each of the 5 wells tested (RRG-1, RRG-2, RRG-3, RRG-4 and RRG-5) was as follows:

- With the well shut in, logging tools were run in the hole to bottom, making stops to measure the static temperature profile. The logging tools included two combination pressure/temperature sensors to provide redundant measurements, with on-board data 
loggers which recorded at intervals of 30 seconds (except in the case of RRG-1, where the interval was 5 seconds).

- The logging tools were pulled up and hung just above the flapper valve (except in RRG-4, which has no flapper valve and therefore the tools were hung near bottom, at 4,820 feet depth).

- The control valve was opened and the well was allowed to produce for a period ranging from 25 hours (in the cases of RRG-3 and RRG-4) to 60 hours (RRG-1).

- During the late part of the flow period, the tool was lowered below the flapper valve (throttling the well back briefly to minimize the risk of parting the wireline) and hung near the bottom of the well, measuring pressure and temperature at this depth for the remainder of the test.

- The well was shut in, and the tools left in the well to monitor pressure buildup for a period ranging from 24 hours (RRG-3) to 89 hours (RRG-4).

Measurements made during each test included:

- Wellhead temperature and pressure (measured on the flowline upstream of the control valve), typically recorded at intervals of 1 minute in the early part of the test and then increasing to 30 minutes.

- Water height above the weir, was recorded at the same intervals of the wellhead pressures. Several methods of measuring water height were implemented; the most reliable proved to be measurement of the length from the top of the weirbox to the water surface, upstream of the weir (and calculating the water height by subtracting the length to the water height when the box was full to the weir with no flow).

- Downhole pressure and temperature, monitored continuously throughout the test (at intervals of 30 seconds or less, as described above). 
Observations with respect to well behavior and test conditions were made and recorded as appropriate. Fluid samples for chemical analysis were collected at least once during the test of each well.

With the exception of RRG-4, each well was allowed to flow with its control valve fully open throughout the production period (except when throttling to move the tool through the flapper valve). RRG-4 quickly developed an intermittent, cyclical flow (with a period of about 40 minutes), which caused downhole pressures to fluctuate. In order to obtain stable conditions for pressure transient analysis, the well was throttle for approximately the last 2.5 hours of the production period to obtain a stable flow rate.

The flow rate of separated water passing through the weirbox was calculated using the standard equation for a V-notch weir. The rate of steam discharged from the separator (as a percentage of total flow) was calculated by assuming flashing to local atmospheric pressure of single-phase water originally at the flowing downhole temperature measured during the test. The total production rate was determined by adjusting the water flow rate based on the calculated lost steam fraction. Some water leakage from the LEAMS separator was observed during production; however, this leakage was estimated to be, at most, a few gpm, which is not significant compared with the overall uncertainty in the measurement of production rate.

The downhole tools were configured with two sensors to provide redundant information. However, one sensor failed during the program and duplicate data (Sensor A and B) was only collected for wells RRG-2, RRG-3 and RRG-5. Figure 1.1 shows the flow rate and downhole pressure histories of RRG-1 during the test. Similarly, Figure 1.2 shows the flow rate and downhole temperature histories of RRG-1 during the same test. Figures 1.3 and 1.4, Figures 1.5 and 1.6, Figures 1.7 and 1.8, and Figures 1.9 and 1.10 show similar test data from RRG-2, RRG3, RRG-4, and RRG-5, respectively. 


\section{GeothermEx, Inc.}

TELEPHONE: (510) 527-9876

FAX: (510) 527-8164

E-MAIL: mw@geothermex.com

Figures 1.11 through 1.15 show the downhole pressure and temperature profiles recorded in wells RRG-1, RRG-2, RRG-3, RRG-4 and RRG-5, respectively, prior to pressure build-up testing. Figure 1.16 is a plot of the measured static pressure at the top of the production interval versus the depth to the top of the production interval for each of the 5 wells. Extrapolating the linear trend of the pressure data points in Figure 1.16 to the surface indicates the existence of an artesian head of $140 \mathrm{psi}$ at the Raft River field. This significant artesian head allowed production of the wells for the flow test program at adequate rates without the need for pumping. 


\section{DATA ANALYSIS METHODOLOGY}

This section presents the quantitative methodology used to interpret the results of the flow and pressure build-up test program and make forecasts of well performance. Section 4 describes the fluid sampling and analysis conducted in conjunction with the flow test and interpretation of the resulting fluid chemistry database.

\subsection{Power Available from the Fluid}

It is possible to estimate the fluid requirement per kilowatt generation capacity, or kilowatt capacity available from a given fluid supply rate, from:

Electrical energy per $\mathrm{lb}$ of fluid $=\mathrm{e} \cdot \mathrm{W}_{\max }$

where $\mathrm{e}=$ utilization efficiency of the power plant, and

$\mathrm{W}_{\max }=$ maximum thermodynamically available work per $\mathrm{lb}$ of fluid.

$\mathrm{W}$ in equation (2.1) is derived from the First and Second Laws of Thermodynamics:

$$
\begin{aligned}
& \mathrm{dq}=c_{\mathrm{p}} \mathrm{dt} \\
& \mathrm{dW}_{\max }=\mathrm{dq}\left(1-\mathrm{T}_{\mathrm{o}} / \mathrm{T}\right)
\end{aligned}
$$

where $c_{p}=$ specific heat of water,

$$
\begin{aligned}
& \mathrm{T}=\text { resource temperature, and } \\
& \mathrm{T}_{\mathrm{o}}=\text { rejection temperature. }
\end{aligned}
$$

For calculation of power capacity, $\mathrm{T}_{\mathrm{o}}$ was assumed to be $60^{\circ} \mathrm{F}$ (average ambient temperature at Raft River) and T was measured for each well during the flow test (Figures 1.2, 1.4, 1.6, 1.8 and 1.10). For power generation from a resource at this temperature range, the binary-cycle 
technology must be used; for modern binary power plants, a value of 0.45 can be assumed for utilization efficiency. If the plant is water-cooled, with a cooling water temperature of $60^{\circ} \mathrm{F}$, the calculated capacities are reasonable. If the plant is air-cooled, $\mathrm{T}_{0}$ will be higher than $60^{\circ} \mathrm{F}$ in the summer and lower than $60^{\circ} \mathrm{F}$ in the winter; however, the average ambient temperature should still not be far from $60^{\circ} \mathrm{F}$.

From the above equations the fluid requirement per MW (gross) generation, not counting the parasitic load of production and injection pumps and power plant auxiliaries, was estimated; Figure 2.1 presents the calculated fluid requirement in gpm per MW (gross) versus resource temperature. Therefore, the next step in this analysis was to estimate the fluid production capacity of the wells, from which the parasitic power needed for pumping and the net power capacity at the wellhead could then be calculated.

\subsection{Initial Well Productivity}

The productive capacity of a geothermal well can be quantified by the parameter Productivity Index $(\mathrm{PI})$, which is defined as the total mass flow rate $(\mathrm{w})$ per unit pressure drawdown $(\Delta \mathrm{p})$, that is,

$$
\mathrm{PI}=\mathrm{w} / \Delta \mathrm{p}
$$

In the above definition $\Delta \mathrm{p}$ can be defined as:

$$
\Delta \mathrm{p}=\mathrm{p}_{\mathrm{i}}-\mathrm{p}
$$

where $p_{i}$ is the initial static pressure in the reservoir and $p$ is the flowing bottom hole pressure at the well, which will decline with time if the well is produced at a constant rate $w$. Therefore, $p$, and consequently PI, of a well flowing at a constant rate declines with time. This decline trend in PI is a function of the hydraulic properties and boundary conditions of the reservoir, and interference effect between wells (if more than one well is active). For such estimation it is 
customary to utilize the so-called Line-Source Solution of the partial differential equation describing transient pressure behavior in a porous medium filled with a single-phase fluid. This solution gives the production rate from a single well in an infinite system as:

$$
w=\frac{2 \pi(k h) \rho(\Delta p)}{\mu p_{D}}
$$

where $\mathrm{k}=$ reservoir permeability,

$\mathrm{h}=$ net reservoir thickness,

$\mathrm{kh}=$ reservoir flow capacity,

$\rho \quad=$ fluid density,

$\mu=$ fluid viscosity, and

$\mathrm{p}_{\mathrm{D}}=$ a dimensionless variable that is a function of time.

In equation $(2.6), p_{D}$ is given by:

$$
p_{D}=-\frac{1}{2} E i\left(\frac{-r_{D}^{2}}{4 t_{D}}\right)
$$

where $t_{D}=$ dimensionless time

$$
\begin{aligned}
& =\frac{(\mathrm{kh}) \mathrm{t}}{\left(\phi \mathrm{c}_{\mathrm{t}} \mathrm{h}\right) \mu \mathrm{r}_{\mathrm{w}}{ }^{2}} \\
\phi \mathrm{c}_{\mathrm{t}} \mathrm{h} & =\text { reservoir storage capacity, } \\
\mathrm{c}_{\mathrm{t}} & =\text { total compressibility of rock and fluid, }
\end{aligned}
$$


E-MAIL: mw@geothermex.com

$$
\begin{aligned}
\phi= & \text { reservoir porosity, } \\
r_{D}= & \text { dimensionless radius, } \\
r \quad= & \text { distance between the line source and the point at which the pressure is being } \\
& \text { considered (equal to wellbore radius if flowing wellbore pressure is being } \\
& \text { considered), } \\
r_{w=}^{=} & \text {wellbore radius, and } \\
t= & \text { time. }
\end{aligned}
$$

In equation (2.7), Ei represents the Exponential Integral, defined by

$$
\operatorname{Ei}(-x)=-\int_{x}^{\infty} \frac{e-u}{u} d u
$$

Equation (2.6) is true if the wellbore skin factor is zero, that is, the wellbore flow efficiency is $100 \%$, the well being neither damaged nor stimulated. If the skin factor is positive (that is, the wellbore is damaged), for the same flow rate $w$, there will be an additional pressure drop given by:

$$
\Delta \mathrm{p}_{\text {skin }}=\frac{\mathrm{w} \mu}{2 \pi(\mathrm{kh}) \rho} \cdot \mathrm{S}
$$

Productive geothermal wells usually display a negative skin factor, which implies a "stimulated" well (that is, the wellbore flow efficiency is greater than 100\%), because such wells intersect open fractures. 


\section{GeothermEx, Inc.}

\subsection{Decline in Well Productivity with Time and due to Well Interference}

From equations (2.4) through (2.9) it is seen that the PI of a well flowing by itself as defined here is independent of the production rate, and can be calculated as a function of time. The PI of a well declines with time, but the decline rate lessens continuously, and after a few months of flow the PI levels off substantially. If more than one well produce from the same reservoir, there will be interference between the wells, reducing the PIs of all wells. From equations (2.4) through (2.9) it is possible to calculate the pressure drawdown at a well, and therefore its PI, in response to both its own production plus the interference effect of simultaneous production from other wells in the field; this is accomplished by the mathematical process of "superposition in space" of the Line-Source Solution, as described below.

If $\mathrm{n}$ wells produce simultaneously, the PI of a well will decline with time according to:

$$
\mathrm{PI}=\frac{2 \pi(\mathrm{kh}) \rho \mathrm{w}}{\mu\left[\sum_{\mathrm{i}=1}^{\mathrm{n}} \mathrm{w}_{\mathrm{i}} \mathrm{p}_{\mathrm{Di}}\left(\mathrm{t}, \mathrm{r}_{\mathrm{i}}\right)+\mathrm{wS}\right]}
$$

and, from (2.7),

$$
p_{D i}\left(t, r_{i}\right)=-\frac{1}{2} E i\left(\frac{-\left(\phi c_{t} h\right) \mu r_{i}^{2}}{4(k h) t}\right)
$$

where $w_{i}$ and $S_{i}$ are the flow rate and skin factor, respectively, of well $I$, and $r_{i}$ is the distance between the subject well and well $i(i=1, \ldots n)$.

Equations (2.10) and (2.11) show that if all wells flow at the same rate, PI becomes independent of flow rate: 


$$
\mathrm{PI}=\frac{2 \pi(\mathrm{kh}) \rho}{\mu\left[\sum_{\mathrm{i}=1}^{\mathrm{n}} \mathrm{p}_{\mathrm{Di}}\left(\mathrm{t}, \mathrm{r}_{\mathrm{i}}\right)+\mathrm{S}\right]}
$$

Similarly, the mathematical process of "super position in time" of the Line-Source Solution can be used to calculate the pressure drawdown and PI when the flow rate is assumed to change with time.

In addition to flow-rate, skin factor, and diameter of the production well whose PI is being considered, the calculation requires the distance to and flow rate from (or injection into) each neighboring active well and estimates of several reservoir parameters. These input parameters are: viscosity and specific volume of the reservoir fluid, reservoir flow capacity (transmissivity), reservoir storage capacity (storativity) and initial reservoir pressure. While reservoir flow capacity and wellbore skin factor values can be estimated from short-term well tests, reservoir storage capacity cannot be estimated without the benefit of an interference test program. However, an average reservoir storage capacity value can be assumed for the calculations discussed below without introducing significant errors. Storage capacity values in the range of 0.001 to $0.1 \mathrm{ft} / \mathrm{psi}$ were reported from the interference tests conducted in the late $1970 \mathrm{~s}$ and early 1980s at Raft River; a mid-range value of $0.01 \mathrm{ft} / \mathrm{psi}$ was assumed for analysis in this report. The specific volume and viscosity of pure water can be used for calculation since the reservoir water at Raft River has a low salinity and low gas concentration. The next section describes the analysis methodology used to arrive at the values of reservoir transmissivity and wellbore skin factor from the flow and pressure build-up tests conducted.

\subsection{Analysis of Flow Test and Pressure-Build-up Data}

The initial productivity index of each well can be approximated as follows:

$$
\mathrm{PI}=\frac{\mathrm{w}}{\mathrm{p}_{\mathrm{s}}-\mathrm{p}_{\mathrm{f}}}
$$


TELEPHONE: (510) 527-9876

FAX: (510) $527-8164$

E-MAIL: mw@geothermex.com

where $\mathrm{w}=$ stabilized flow rate prior to shut-in,

$\mathrm{p}_{\mathrm{f}}=$ flowing wellbore pressure just prior to shut-in, and

$\mathrm{p}_{\mathrm{s}}=$ final build-up pressure

However, forecast of the decline in PI with time and due to interference between wells requires the use of equations (2.10) and (2.11); this, in turn, requires the estimation of reservoir flow capacity and skin factor.

The approach used here to estimate flow capacity and skin factor of a well was to match, by trial and error, the observed pressure build-up behavior of the well to that calculated according to the following mathematical model for wellbore pressure build-up versus time, taking into account the intertwined effects of skin factor and wellbore storage effects:

Pressure build-up:

$$
\mathrm{p}_{\mathrm{ws}}=\mathrm{p}_{\mathrm{i}}-\frac{\mathrm{w} \mu}{2 \pi(\mathrm{kh}) \rho}\left\{\mathrm{p}_{\mathrm{D}}\left(\left[\mathrm{t}_{\mathrm{p}}+\Delta \mathrm{t}\right]_{\mathrm{D}}\right)-\mathrm{p}_{\mathrm{D}}\left(\Delta \mathrm{t}_{\mathrm{D}}\right)\right\}
$$

where $p_{w s}=$ well pressure at a build-up time $\Delta t$,

$t_{p}=$ duration of production prior to shut-in,

$\mathrm{w}=$ average production rate prior to shut-in, and

$p_{D}$ is as described by $(2.7)$.

Skin Factor:

Defined by equation (2.9)

Wellbore Storage: 


$$
\mathrm{w}_{\mathrm{bh}}=\mathrm{w}\left[1-\mathrm{C}_{\mathrm{D}} \frac{\mathrm{d}}{\mathrm{dt}_{\mathrm{D}}} \mathrm{p}_{\mathrm{D}}\left(\mathrm{t}_{\mathrm{D}}, \mathrm{C}_{\mathrm{D}}\right)\right] \text {, }
$$

where $w_{b h}=$ flow rate from the reservoir to the bottom of the well even after the well has been shut-in at the wellhead,

$C_{D}=$ dimensionless wellbore storage

$$
=\frac{C}{2 \pi\left(\phi c_{t} h\right) r_{w}^{2}} \text {, and }
$$

$\mathrm{C}=$ wellbore storage coefficient (volume stored in the well per unit pressure increase).

Reservoir flow capacity, skin factor and wellbore storage estimates (in reservoir barrels per psi) were varied by trial and error until convergence was obtained between the measured and calculated pressure build-up behavior within an acceptable tolerance level.

One needs to estimate the maximum available pressure drawdown $(\Delta p)$ at a well before its maximum production rate can be calculated. Since the wells at Raft River will be pumped, the next step in the analysis was to estimate the maximum available drawdown for pumping of these wells and the parasitic load of this pumping. The next section therefore considers the intertwined issues related to well pumping and parasitic load.

\subsection{Well Pumping Issues}

In a pumped well, the water level must lie above the pump intake; otherwise the pump will cavitate. For any given pump setting depth, the maximum available pressure drawdown $(\Delta p)$ in a pumped well without the risk of cavitation can be estimated from:

$$
\Delta p=p_{i}-\left(h-h_{p}\right) G-p_{s a t}-p_{g a s}-p_{s u c}-p_{f r}-p_{s m}
$$

where $p_{i}=$ initial static reservoir pressure, 
E-MAIL: mw@geothermex.com

$\mathrm{h}=$ depth to production zone,

$h_{p}=$ pump setting depth,

$\mathrm{G}=$ hydrostatic gradient at production temperature,

$\mathrm{p}_{\mathrm{sat}}=$ fluid saturation pressure at production temperature,

$\mathrm{p}_{\text {gas }}=$ gas partial pressure,

$\mathrm{p}_{\mathrm{suc}}=$ net positive suction head required by pump,

$\mathrm{p}_{\mathrm{fr}}=$ pressure loss due to friction in well between $h$ and $h_{p}$, and

$\mathrm{p}_{\mathrm{sm}}=$ additional safety margin to ensure cavitation does not occur at pump intake

The pressure loss due to friction $\left(\mathrm{p}_{\mathrm{fr}}\right)$ in equation $(2.16)$ can be calculated as follows:

$$
p_{\mathrm{fr}}=\frac{f \rho v^{2}}{2 g_{c} d}\left(h-h_{p}\right),
$$

where $f=$ moody friction factor,

$$
\begin{aligned}
& \mathrm{v}=\text { fluid velocity in well, } \\
& \rho=\text { fluid density, } \\
& \mathrm{d}=\text { internal diameter of the wellbore, and } \\
& \mathrm{g}_{\mathrm{c}}=\text { gravitational unit conversion factor. }
\end{aligned}
$$

The value of $f$ in (2.17) can be calculated from:

$$
\mathrm{f}=\left[1.14-2 \log \left(\in / \mathrm{d}+9.35\left(\mathrm{f}^{-1 / 2}\right) / \mathrm{N}_{\mathrm{Re}}\right]^{-2}\right.
$$


where $\epsilon$ is relative roughness of the pipe.

In (2.18), $\mathrm{N}_{\mathrm{Re}}$ is Reynold's Number, given by:

$$
\mathrm{N}_{\mathrm{Re}}=\rho \mathrm{vd} / \mu
$$

where $\mu$ is fluid viscosity.

The maximum available pressure drawdown can be derived from equations (2.16) through (2.19).

The pump can be set as deep as 1,500 feet if a line shaft pump is used, but if an electric submersible pump is used it can be set considerably deeper. U.S. Geothermal proposes to utilize submersible pumps. Some of the above-mentioned parameters were specified by U.S. Geothermal based on their discussion with the pump manufacturers (Kevin Kitz, personal communication, October 1-4, 2004); these are described later. The remaining parameters in equation (2.16) were either known or measured, or estimated from the fluid characteristics. From the calculated value of the PI of a well and maximum allowable pressure drawdown, one can calculate, as a function of time, the maximum available production rate (w) given by:

$$
\mathrm{w}=(\mathrm{PI}) \cdot(\Delta \mathrm{p})
$$

The power required for pumping must be subtracted from the gross power available from the pumped well. The power required by a pump operating at the maximum allowable drawdown condition is given by:

$$
\text { Pumping power }=\left(w \cdot H / E_{p}+h_{p} \cdot L\right) / E_{m} \text {, }
$$

where $\mathrm{H}=$ total delivered head,

$\mathrm{L}=$ shaft horsepower loss per unit length, 


$$
\begin{aligned}
& E_{p}=\text { pump efficiency, and } \\
& E_{m}=\text { motor efficiency. }
\end{aligned}
$$

In equation (2.21), $\mathrm{H}$ is given by:

$$
H=\left(p_{d}-p_{s a t}-p_{\text {gas }}-p_{s m}\right) / G+h_{p}
$$

where $p_{d}=$ pump discharge pressure.

The following parameters were specified by U.S. Geothermal, and have been used as such in this analysis:

- Casing $\mathrm{ID}=8.75$ inches $(9-5 / 8$ inch $\mathrm{OD})$

- $p_{\text {gas }}+p_{\text {suc }}+p_{s m}=200$ feet of head ( $p_{\text {gas }}$ was determined as indicated in Section 4.3 and in footnotes to Tables 3.1 through 3.4 )

- $\mathrm{L}=0$

- $\mathrm{E}_{\mathrm{p}}=0.76$

- $E_{m}=0.88$

- $\mathrm{p}_{\mathrm{d}}=80$ psia for wells RRG-1, RRG-2 and RRG-5; 120 psia for RRG-3

- $\mathrm{hp}=$ no limit for RRG-1 and RRG-2; 1,165 feet for RRG-3; and 1,226 feet for RRG-5

- horsepower limit $=1,000$ for submersible pumps and 1,500 for line-shaft pumps. 


\section{RESULTS OF FLOW AND PRESSURE BUILD-UP TESTS}

This section presents the results of flow and pressure build-up tests conducted for each well; the results of fluid sampling and analysis are described in Section 4.

\subsection{Initial Well Productivity}

Based on the stabilized flow rate measured just prior to shut-in and the total pressure build-up following shut-in, the initial productivity index for each well was calculated using equation (2.13). The flow rate and pressure build-up data have been presented in Figures 1.1, 1.3, 1.5, 1.7 and 1.9 for RRG-1, RRG-2, RRG-3, RRG-4 and RRG-5, respectively. The estimates of initial PI were as follows:

\begin{tabular}{|c|c|}
\hline Well & $\frac{\text { Productivity }}{\underline{\text { Index }}} \underset{\text { (gpm/psi) }}{ }$ \\
\hline RRG-1 & 3.2 \\
\hline RRG-2 & 2.6 \\
\hline RRG-3 & 3.3 \\
\hline RRG-4 & 0.3 \\
\hline RRG-5 & 2.9 \\
\hline
\end{tabular}

The above table indicates that well RRG-4 has too low a PI to be considered commercial. The remaining 4 wells show eminently commercial and remarkably similar PI values. This observation implies that:

(a) the Raft River field has commercially attractive flow capacity; and 
(b) there is little influence of any specific faults or local geologic control on well productivity, implying a relatively low risk in well siting.

\subsection{Initial Power Capacity}

Table 3.1 presents the values of the parameters used (on the first page) and estimated flow rate (gallons per minute), gross power capacity (MW) and net power capacity (MW) versus pump setting depth (feet), on the second page, for well RRG-1 at the initial condition. The calculation follows the methodology presented in Sections 2.1 and 2.5. Figure 3.1 shows the initial gross capacity and initial net capacity (after deducting the parasitic load for pumping) as a function of pump setting depth for well RRG-1. Similar tabular information for wells RRG-2, RRG-3 and RRG-5 are shown in Tables 3.2,3.3 and 3.4, respectively. Figures 3.2, 3.3 and 3.4 present graphically the gross and net initial power capacities versus pump setting depth for wells RRG-2, RRG-3 and RRG-5, respectively. These calculations were not conducted for RRG-4 as this well was considered non-commercial.

The changes in well productivity with time and due to well interference can be calculated using the methodology presented in Sections 2.2 and 2.3; however, for this calculation one needs to estimate the reservoir flow capacity and skin factor for each well. This has been done from the analysis of the build-up test results (Figures 1.1 through 1.10) using the methodology presented in Section 2.4 .

\subsection{Analysis of Pressure Build-up Data}

For each well the observed pressure build-up behavior was matched, by trial and error, to that calculated from equations $(2.14),(2.9)$ and (2.15). The parameters varied in the trial-and-error matching process were: reservoir flow capacity, skin factor and wellbore storage. The goodness of the match was assessed from the ability to reach convergence and the calculated confidence intervals for the parameters. 
Figures 3.5 shows the match between the measured and calculated pressure build-up behavior for RRG-1; this match was obtained for a reservoir flow capacity of 34,000 md-ft and a skin factor value of 2.2. Figure 3.6 shows the same match for RRG-1 but on a log-log plot; the quality of the match is better discerned on a $\log -\log$ plot. Similarly, Figures 3.7 and 3.8, Figures 3.9 and 3.10, Figures 3.11 and 3.12, and Figures 3.13 and 3.14 show the pressure build-up data matches for wells RRG-2, RRG-3, RRG-4 and RRG-5, respectively.

Table 3.5 summarizes the relevant results obtained from the analysis of pressure build-up data for all wells. Table 3.5 also indicates the match quality, based on, the confidence interval achieved for the estimated parameters. Data from RRG-1 and RRG-4 allowed good matches and data from RRG-2 and RRG-3 allowed matches that are questionable, while the data from RRG-5 proved uninterpretable. However, it should be noted that for the wells with questionable or uninterpretable build-up behavior, one can still use the calculated initial PI values and normalize the information against those form wells RRG-1 and RRG-4, for which good matches were possible, to allow reasonable forecast of productivity decline with time and due to well interference. This exercise is present below.

\subsection{Forecast of Power Capacity Decline}

In estimating the effect of well interference on PI one has to estimate an effective reservoir-wide flow capacity, which is invariably higher than can be measured from short-term tests of single wells. Even if long-term interference testing involving multiple wells is conducted, the choice of a reservoir-wide flow capacity to be used for interference calculation can be rather subjective.

For this analysis, we considered the flow capacity of RRG-1, which has the highest value among the 5 wells, to be a reasonable, if not conservative, estimate of the reservoir-wide flow capacity. In interference tests conducted at Raft River in the late 1970s and early 1980s, reservoir flow capacity values as high as $200,000 \mathrm{md}$-ft were reported; however, reliability of those old results cannot be assessed with any confidence. For any well other than RRG-1, a "pseudo" skin factor value was calculated assuming a reservoir flow capacity of $34,000 \mathrm{md}-\mathrm{ft}$. The pseudo skin factor 
was calculated such that the initial PI of the well (for a reservoir flow capacity of $34,000 \mathrm{md}-\mathrm{ft}$ ) is the same as estimated in Section 3.1. Theses pseudo skin factor values are listed in Table 3.5.

Using an effective reservoir-wide flow capacity of $34,000 \mathrm{md}-\mathrm{ft}$, a reservoir storage capacity of $0.01 \mathrm{ft} / \mathrm{psi}$ (as assumed in Section 2.3) and the pseudo skin factor values listed in Table 3.5, the decline in PI of each well with time, taking into account the interference between the wells, was calculated using the methodology presented in Section 2.3. Then using the methodology presented in Section 2.5 and the assumptions listed in Tables 3.1 through 3.4, the decline in net power capacity of each well as a function of pump setting depth and time could be calculated with due recognition to the interference effect between the wells.

Figure 3.15 presents the forecast of decline in the net power capacity of well RRG-1 as a function of both pump setting depth and time. Figures $3.16,3.17$ and 3.18 present the same type of forecast for wells RRG-2, RRG-3 and RRG-5, respectively.

\subsection{Sustainable Plant Capacity}

Given the specified horsepower limits (1,000 for electric submersible and 1,500 for line-shaft pumps) we calculate the following range of pump setting depths using the methodology of section 2.5:

\begin{tabular}{|l|c|c|}
\hline Well & $\begin{array}{c}\text { Deepest Practical Setting } \\
\text { Depth for Electric } \\
\text { Submersible Pump (Ft) }\end{array}$ & $\begin{array}{c}\text { Deepest Practical Setting } \\
\text { Depth for Line-shaft Pump } \\
\text { (Ft) }\end{array}$ \\
\hline RRG-1 & 1,570 & 1,500 \\
\hline RRG-2 & 1,650 & 1,500 \\
\hline RRG-3 & 1,165 & 1,165 \\
\hline RRG-5 & 1,226 & 1,226 \\
\hline
\end{tabular}


For electrical submersible pumps the depth limit from the above table would be between 1,165 to 1,650 feet. For line-shaft pumps, for which US Geothermal has specified a maximum pump setting depth of 1,500 feet, the maximum practical pump setting depth would vary from 1,165 to 1,500 feet.

The above discussion shows that irrespective of pump technology to be used, pump setting depth for all practical purposes would range from 1,165 to 1,650 feet. Furthermore, electric submersible pumps would allow the deepest overall pump setting depths in the existing wells. Assuming the use of electrical submersible pumps, we estimate the initial MW capacity (after subtracting pump parasitic) as follows:

\begin{tabular}{|l|c|c|}
\hline Well & Pump Setting Depth (Ft) & Initial MW Capacity \\
\hline RRG-1 & 1,570 & 4.05 \\
\hline RRG-2 & 1,650 & 3.59 \\
\hline RRG-3 & 1,165 & 3.50 \\
\hline RRG-5 & 1,226 & $\underline{2.63}$ \\
\hline
\end{tabular}

Total:

13.77

Therefore, an initial capacity of $13.77 \mathrm{MW}$ (net) will be available at the plant inlet from the existing wells. Figure 3.23 shows the approximate calculated decline in this initial capacity with time over 20 years. Even assuming the need for as much as $20 \%$ of the capacity for plant auxiliaries and injection parasitic, the initial capacity should be sufficient to start a $10 \mathrm{MW}$ (net) plant. Figure 3.23 indicates that a make-up well will be needed one to two years after plant startup to maintain a $10 \mathrm{MW}$ (net) capacity at the busbar.

It is estimated that 3 or 4 good injection wells will be required for a $10 \mathrm{MW}$ (net) plant. The non-commercial producer RRG-4 was originally drilled as an injection well but was found to short-circuit fluids to RRG-1; therefore, this well cannot be used as is. It is likely that this well 
TELEPHONE: (510) 527-9876

FAX: (510) 527-8164

E-MAIL: mw@geothermex.com

can be reworked as an injector or producer. The two shallow existing wells RRG-6 and RRG-7 can be deepened or "forked" and used as injectors. Therefore, at least one new injection well will have to be drilled for a $10 \mathrm{MW}$ (net) project. The 3 existing potential injectors (RRG-4, RRG-6 and RRG-7) with appropriate reworking would be able to support about half of the 10 MW (net) capacity. 


\section{RESULTS OF FLUID SAMPLING AND ANALYSIS}

\subsection{Sample Collection, Analyses and Reporting}

During each well test, water and steam samples were obtained from the flow line near the wellhead by use of a portable steam-water sampling separator provided by GeothermEx. The first well test was sampled by GeothermEx, with training provided to U.S. Geothermal staff. Subsequent tests were sampled by U.S. Geothermal. Sample containers and chemical analyses were provided by Thermochem, Inc., of Santa Rosa, CA. Each well was sampled twice, except for RRG-4, which was sampled once. Samples of water and gases were also collected for government-funded isotope analyses at Lawrence Berkeley Laboratory: the analyses of these are not yet complete (as of October 18, 2004).

Water samples were collected from the portable separator and split into three portions: (a) unfiltered and untreated (for anions and $\mathrm{pH}$ ); (b) filtered ( 0.45 micron) and acidified (nitric acid) (for cations); and (c) filtered-diluted in 0.1 nitric acid (for silica). Steam samples were collected into evacuated containers that contained sodium hydroxide-cadmium chloride solution, which captures and preserves acidic gas components $\left(\mathrm{CO}_{2}, \mathrm{H}_{2} \mathrm{~S}\right)$ for wet chemical analysis and concentrates the non-reactive gas components for gas chromatographic analysis.

The steam fraction at steam-water sample separation conditions was calculated from the temperature in the portable separator and the enthalpy of total discharge at the wellhead, which was estimated from temperature logged downhole below the level of boiling (discounted by $1{ }^{\circ} \mathrm{C}$ for wellbore cooling).

Results of the analyses have been reported by Thermochem and these data have been integrated into GeothermEx's database of Raft River fluids chemistry previously reported in a technical report on the resource to U.S. Cobalt in August 2002. The new water analyses are reproduced herein as table 4.1 parts 1 to 3 , and aqueous geothermometer temperatures calculated from these 
TELEPHONE: (510) 527-9876

FAX: $(510)$ 527-8164

E-MAIL: mw@geothermex.com

are reproduced as table 4.2. The new gas/steam data are reproduced as table 4.3 , which also contains the small amount of previously available gas data.

\subsection{Water Chemistry}

The 2004 test water samples are in good agreement with chemical data obtained in the 1970s, confirming the presence in the reservoir of a sodium-chloride $(\mathrm{Na}-\mathrm{Cl})$ water which has lower salinity at wells along the range-front $(\mathrm{Cl} 650-875 \mathrm{mg} / \mathrm{kg})$, and higher salinity at wells in the basin ( $\mathrm{Cl} 2600 \mathrm{mg} / \mathrm{kg}$ at RRGE-3). At all wells, there is good agreement between measured downhole temperature and the silica (chalcedony) temperature, whereas higher cation (Na-K-Ca) temperatures suggest somewhat hotter conditions at greater depth.

The hottest well in terms of both measured downhole temperature and chemical geothermometry is the basin well RRGE-3: measured $144^{\circ} \mathrm{C}$ and $\mathrm{Na}-\mathrm{K}-\mathrm{Ca} 180-185^{\circ} \mathrm{C}$. The range-front wells are only slightly cooler in spite of a lower salinity: measured $139-141^{\circ} \mathrm{C}$ and $\mathrm{Na}-\mathrm{K}-\mathrm{Ca} 174-180^{\circ} \mathrm{C}$. By comparison, the version of the $\mathrm{Na}-\mathrm{K}-\mathrm{Ca}$ geothermometer being used herein has an uncertainty of about + or $-20^{\circ} \mathrm{C}$, although greater errors are possible.

\subsection{Gas Chemistry}

Gas data had not been obtained from well RRGE-3 prior to this flow test, and the better of the two samples collected shows gases in steam at $750 \mathrm{ppmw}$, and gases in total flow at $41 \mathrm{ppmw}$ (gases in the other sample were slightly diluted by brine carry-over in the portable separator). Hydrogen sulfide was $4.4 \mathrm{ppmw}$ in steam, and so less than $1 \mathrm{ppm}$ in total flow. The gas composition is $44-51$ vol.\% nitrogen $\left(\mathrm{N}_{2}\right)$, and $48-52$ vol.\% carbon dioxide $\left(\mathrm{CO}_{2}\right)$, which is about as expected from a reservoir of this temperature and composition.

None of the steam samples from the other wells, at the range-front, contained gases above reported detection limits of 30 ppmw at wells RRGE-1, RRGE-2 and RRGP-5, and 107 ppmw at RRGP-4 (a high limit most-likely due to small sample size and air contamination). These 


\section{GeothermEx, Inc.}

TELEPHONE: (510) 527-9876

FAX: (510) 527-8164

E-MAIL: mw@geothermex.com

detection limits are somewhat uncertain, because the samples generally contained some air contamination and additionally were probably contaminated by very roughly $10 \%$ to $25 \%$ brinecarryover from the portable separator (allowed by connection of the separator to a horizontal sampling port instead of a vertical one; a vertical port was used at RRGE-3). Carryover is estimated very approximately from the conductivity of the steam condensate measured before or after sample collection (details are in table 4.3).

Although brine contamination would dilute a steam sample and cause gases to be under-reported, it is improbable that the amount of brine contamination in any of the range-front steam samples was enough to mask a gas concentration anywhere close to the level measured at RRGE-3. The three steam samples obtained in the 1970s (one each from the BLM well, RRGE-1 and RRGE-2) showed gas/steam at $16-42 \mathrm{ppmw}$, so it is concluded that the range front wells have extremely low gas contents, probably about $30-40$ ppmw in steam at about $5 \%$ steam fraction, or less than 2 ppmw in total flow, and perhaps as high as about $60 \mathrm{ppmw}$ in steam.

\subsection{Comments}

The cause of the difference in chemistry between range front wells and basin wells remains incompletely understood, except that the range front wells may be producing fluids derived mostly on in part from basement rocks and/or diluted by recharge through mountains to the west, whereas the basin wells show the effects of fluids concentration within basin sediments.

Drilling and testing of wells in the one mile gap between RRGP-4 (range front chemistry) and RRGE-3 (basin chemistry) may provide data which will help explain the difference. It may be noted that samples obtained from RRGP-4 in the 1970s showed a range of Cl of 1370 to 2575 $\mathrm{mg} / \mathrm{kg}$, characteristic of the basin water type, or a mixture, whereas RRGP-4 has now produced $\mathrm{Cl}$ at $879 \mathrm{mg} / \mathrm{kg}$ (range front or slightly mixed water type). The RRGP-4 samples from the 1970s are not well-documented, and some may have been collected before the well was reworked and casing deepened in November 1979. Others may have been affected by prior injection into the well (although an undated sample with $1630 \mathrm{mg} / \mathrm{kg} \mathrm{Cl}$ was "assumed to be 
TELEPHONE: $(510) 527-9876$

FAX: (510) 527-8164

E-MAIL: mw@geothermex.com

representative of aquifer water."). In any case, the current chemistry of the well is consistent with the fact that only the very bottom 400 feet are open, and most or all of this interval is in basement rock. 


\section{CONCLUSIONS}

1. Four of the five existing wells are usable as commercial production wells without the need for any major rework.

2. The non-commercial well, RRG-4, should be studied for re-drilling a directional leg toward a more productive zone, which would provide capital savings over drilling a new production well from surface.

3. The wells exhibit an artesian head of $140 \mathrm{psi}$, and produce a very low salinity water, and with a very low dissolved gas content, at temperatures of $272^{\circ}$ to $300^{\circ} \mathrm{F}$.

4. The four commercially productive wells have attractive productivity index values (in the range of 2.6 to $3.3 \mathrm{gpm} / \mathrm{psi}$ initially); well RRG-4 is non-commercial.

5. The similarity of the productivity index values of all four productive wells indicates the absence of any major control of faults or local geological conditions on well productivity; this reduces well siting risk.

6. The effective reservoir flow capacity is on the order of 34,000 millidarcy-feet and the effective skin factor values of the wells range from 1.9 to 4.7 .

7. After one year of production, the net power capacity from the 4 wells (after subtracting the parasitic load of pumping) will be about $13 \mathrm{MW}$ for a pump setting depth of 1,500 feet to $20 \mathrm{MW}$ for a pump setting depth of 3,000 feet.

8. After 20 years of operation with fixed pump setting depths and without drilling make-up wells, net power capacity from the 4 wells (after subtracting the parasitic load for pumping) will vary from about $9.5 \mathrm{MW}$ for a 1,500 feet pump setting depth to $14.5 \mathrm{MW}$ for a 3,000 feet pump setting depth. 
9. For existing wells RRG-1, RRG-2, RRG-3 and RRG-5, the maximum available setting depths for electric submersible pumps are 1,570 feet, 1,650 feet, 1,165 feet and 1,226 feet, respectively. With these pump setting depths, the initial MW capacity (after subtracting the pump parasitic) will amount to $13.8 \mathrm{MW}$. Assuming a $20 \%$ reduction in net capacity at the busbar (for plant auxiliaries and injection parasitic), a $10 \mathrm{MW}$ (net) plant can be initially supported by the existing wells. However, a make-up production well will be required after one to two years of plant operation.

10. It is estimated that 3 or 4 good injection wells will be required for a $10 \mathrm{MW}$ (net) plant. The non-commercial producer RRG-4 and two shallow existing wells RRG-6 and RRG-7 can be reworked, deepened and "forked" and used as injectors. Therefore, at least one new injection well will have to be drilled for a $10 \mathrm{MW}$ (net) project. The 3 existing potential injectors (RRG-4, RRG-6 and RRG-7) would be able to support about half of the $10 \mathrm{MW}$ (net) capacity. 
Table 3.1. Pump Calculation for Well RRG-1

Input Parameters

Productivity index:

Static pressure at production level:

Depth to production level:

Density of produced water:

Vapor pressure at temperature of produced water:

Gas partial pressure*:

Pump suction pressure:

Pressure safety margin:

Relative roughness:

Casing ID:

Viscosity of produced water:

Pump discharge pressure:

Pump efficiency:

Motor efficiency:

Power loss per unit length of pump shaft:

Parasitic load factor:

Temperature of produced water:

Rejection temperature:

Average specific heat of water between $\mathrm{T}$ and $\mathrm{T} 0$ :

Utilization factor:

Number of wells:

Surface pipeline length:

Surface pipeline ID:

Increase in net elevation in pipeline run:
$3.2 \mathrm{gpm} / \mathrm{psi}$

1,650 psia

3,630 feet

$57.77 \mathrm{lb} / \mathrm{ft}^{3}$

53.26 psia

$1.95 \mathrm{psi}$

68 psi

$10 \mathrm{psi}$

0.0006 feet

8.75 inches

$0.2 \mathrm{cp}$

80 psia

0.76

0.88

$0 \mathrm{hp} / \mathrm{ft}$

0

$285^{\circ} \mathrm{F}$

$60 \quad{ }^{\circ} \mathrm{F}$

$1 \mathrm{BTU} / \mathrm{lb} /{ }^{\circ} \mathrm{F}$

0.45

1

0 feet

0 inches

0 feet

*Maximum likely value, based on $\mathrm{CO}_{2} / \mathrm{stm}=10 \mathrm{mg} / \mathrm{kg}, \mathrm{N}_{2} / \mathrm{stm}=35 \mathrm{mg} / \mathrm{kg}$ (actual gases in 2004 were " $<\mathrm{DL}$ of $30 \mathrm{ppm}$ ", but data from 1970s imply possibly $30-40 \mathrm{ppm}$, to maybe $60 \mathrm{ppm}$ ) 
Table 3.1. Pump Calculation for Well RRG-1 (continued)

Results

\begin{tabular}{|c|c|c|c|c|c|c|c|}
\hline \multirow{2}{*}{$\begin{array}{c}\text { Depth } \\
\text { (feet) }\end{array}$} & \multirow{2}{*}{$\begin{array}{c}\text { Drawdown } \\
\text { (feet) }\end{array}$} & \multicolumn{2}{|c|}{ Flow Rate } & \multirow{2}{*}{$\begin{array}{l}\text { Head } \\
\text { (feet) }\end{array}$} & \multicolumn{3}{|c|}{ Gross } \\
\hline & & $(\mathrm{gpm})$ & $(\mathrm{lb} / \mathrm{hr})$ & & MW used & $\mathrm{MW}$ & Net MW \\
\hline 3,630 & $1,516.8$ & $4,853.9$ & $2,249,199$ & $3,497.4$ & 4.431 & 11.281 & 6.850 \\
\hline 3,530 & $1,466.6$ & $4,693.3$ & $2,174,816$ & $3,397.4$ & 4.162 & 10.908 & 6.746 \\
\hline 3,430 & $1,417.8$ & $4,537.1$ & $2,102,407$ & $3,297.4$ & 3.905 & 10.545 & 6.640 \\
\hline 3,330 & $1,370.1$ & $4,384.5$ & $2,031,689$ & $3,197.4$ & 3.660 & 10.190 & 6.531 \\
\hline 3,230 & $1,323.6$ & $4,235.5$ & $1,962,654$ & $3,097.4$ & 3.425 & 9.844 & 6.419 \\
\hline 3,130 & $1,278.0$ & $4,089.7$ & $1,895,115$ & $2,997.4$ & 3.200 & 9.505 & 6.305 \\
\hline 3,030 & $1,233.4$ & $3,946.9$ & $1,828,949$ & $2,897.4$ & 2.985 & 9.173 & 6.188 \\
\hline 2,930 & $1,189.6$ & $3,806.9$ & $1,764,041$ & $2,797.4$ & 2.780 & 8.848 & 6.068 \\
\hline 2,830 & $1,146.6$ & $3,669.3$ & $1,700,291$ & $2,697.4$ & 2.584 & 8.528 & 5.944 \\
\hline 2,730 & $1,104.3$ & $3,534.0$ & $1,637,602$ & $2,597.4$ & 2.396 & 8.214 & 5.817 \\
\hline 2,630 & $1,062.7$ & $3,400.8$ & $1,575,887$ & $2,497.4$ & 2.217 & 7.904 & 5.687 \\
\hline 2,530 & $1,021.7$ & $3,269.6$ & $1,515,064$ & $2,397.4$ & 2.046 & 7.599 & 5.553 \\
\hline 2,430 & 981.2 & $3,140.1$ & $1,455,057$ & $2,297.4$ & 1.883 & 7.298 & 5.415 \\
\hline 2,330 & 941.3 & $3,012.2$ & $1,395,794$ & $2,197.4$ & 1.728 & 7.001 & 5.273 \\
\hline 2,230 & 901.8 & $2,885.7$ & $1,337,208$ & $2,097.4$ & 1.580 & 6.707 & 5.127 \\
\hline 2,130 & 862.7 & $2,760.6$ & $1,279,234$ & $1,997.4$ & 1.439 & 6.416 & 4.977 \\
\hline 2,030 & 824.0 & $2,636.7$ & $1,221,812$ & $1,897.4$ & 1.306 & 6.128 & 4.822 \\
\hline 1,930 & 785.6 & $2,513.9$ & $1,164,883$ & $1,797.4$ & 1.179 & 5.843 & 4.663 \\
\hline 1,830 & 747.5 & $2,392.0$ & $1,108,390$ & $1,697.4$ & 1.060 & 5.559 & 4.499 \\
\hline 1,730 & 709.6 & $2,270.9$ & $1,052,279$ & $1,597.4$ & 0.947 & 5.278 & 4.331 \\
\hline 1,630 & 672.1 & $2,150.8$ & 996,625 & $1,497.4$ & 0.841 & 4.999 & 4.158 \\
\hline 1,530 & 634.7 & $2,031.0$ & 941,116 & $1,397.4$ & 0.741 & 4.720 & 3.979 \\
\hline 1,430 & 597.4 & $1,911.7$ & 885,832 & $1,297.4$ & 0.647 & 4.443 & 3.796 \\
\hline 1,330 & 560.2 & $1,792.7$ & 830,722 & $1,197.4$ & 0.560 & 4.167 & 3.606 \\
\hline 1,230 & 523.1 & $1,674.1$ & 775,735 & $1,097.4$ & 0.480 & 3.891 & 3.411 \\
\hline 1,130 & 486.1 & $1,555.6$ & 720,821 & 997.4 & 0.405 & 3.615 & 3.210 \\
\hline 1,030 & 449.1 & $1,437.1$ & 665,931 & 897.4 & 0.337 & 3.340 & 3.003 \\
\hline 930 & 412.0 & $1,318.6$ & 611,013 & 797.4 & 0.274 & 3.065 & 2.790 \\
\hline 830 & 375.0 & $1,199.9$ & 556,014 & 697.4 & 0.218 & 2.789 & 2.570 \\
\hline 730 & 337.8 & $1,080.9$ & 500,882 & 597.4 & 0.169 & 2.512 & 2.344 \\
\hline 630 & 300.5 & 961.5 & 445,560 & 497.4 & 0.125 & 2.235 & 2.110 \\
\hline 530 & 263.0 & 841.6 & 389,964 & 397.4 & 0.087 & 1.956 & 1.869 \\
\hline 430 & 225.3 & 721.0 & 334,099 & 297.4 & 0.056 & 1.676 & 1.620 \\
\hline 330 & 187.4 & 599.6 & 277,862 & 197.4 & 0.031 & 1.394 & 1.363 \\
\hline 230 & 149.2 & 477.3 & 221,187 & 97.4 & 0.012 & 1.109 & 1.097 \\
\hline 130 & 110.6 & 353.9 & 164,001 & -2.6 & 0.000 & 0.823 & 0.823 \\
\hline 30 & 71.6 & 229.2 & 106,229 & -102.6 & -0.006 & 0.533 & 0.539 \\
\hline
\end{tabular}


Table 3.2. Pump Calculation for Well RRG-2

Input Parameters

Productivity index:

Static pressure at production level:

$2.6 \mathrm{gpm} / \mathrm{psi}$

Depth to production level:

1,900 psia

Density of produced water:

4,220 feet

Vapor pressure at temperature of produced water:

$57.67 \mathrm{lb} / \mathrm{ft}^{3}$

Gas partial pressure*:

55.8 psia

Pump suction pressure:

$1.95 \mathrm{psi}$

68 psi

Pressure safety margin:

$10 \mathrm{psi}$

Relative roughness:

Casing ID:

0.0006 feet

Viscosity of produced water:

8.75 inches

Pump discharge pressure:

$0.2 \mathrm{cp}$

Pump efficiency:

80 psia

Motor efficiency:

0.76

0.88

Power loss per unit length of pump shaft:

Parasitic load factor:

Temperature of produced water:

$0 \mathrm{hp} / \mathrm{ft}$

0

$288{ }^{\circ} \mathrm{F}$

Rejection temperature:

$60{ }^{\circ} \mathrm{F}$

Average specific heat of water between $\mathrm{T}$ and $\mathrm{T} 0$ :

$1 \mathrm{BTU} / \mathrm{lb} /{ }^{\circ} \mathrm{F}$

Utilization factor:

0.45

Number of wells:

Surface pipeline length:

Surface pipeline ID:

Increase in net elevation in pipeline run:

0 feet

0 inches

0 feet

*Maximum likely value, based on $\mathrm{CO}_{2} / \mathrm{stm}=10 \mathrm{mg} / \mathrm{kg}, \mathrm{N}_{2} / \mathrm{stm}=35 \mathrm{mg} / \mathrm{kg}$ (actual gases in 2004 were " $<$ DL of 30 ppm", but data from 1970s imply possibly $30-40 \mathrm{ppm}$, to maybe $60 \mathrm{ppm}$ ) 
Table 3.2. Pump Calculation for Well RRG-2 (continued)

\begin{tabular}{|c|c|c|c|c|c|c|c|}
\hline \multirow{2}{*}{$\begin{array}{l}\text { Depth } \\
\text { (feet) }\end{array}$} & \multirow{2}{*}{$\begin{array}{c}\text { Drawdown } \\
\text { (feet) }\end{array}$} & \multicolumn{2}{|c|}{ Flow Rate } & \multirow{2}{*}{$\begin{array}{l}\text { Head } \\
\text { (feet) }\end{array}$} & \multicolumn{3}{|c|}{ Gross } \\
\hline & & $(\mathrm{gpm})$ & $(\mathrm{lb} / \mathrm{hr})$ & & MW used & MW & Net MW \\
\hline 4,220 & $1,764.3$ & $4,587.2$ & $2,121,942$ & $4,080.8$ & 4.878 & 10.898 & 6.019 \\
\hline 4,120 & $1,715.1$ & $4,459.5$ & $2,062,882$ & $3,980.8$ & 4.626 & 10.594 & 5.968 \\
\hline 4,020 & $1,667.1$ & $4,334.5$ & $2,005,036$ & $3,880.8$ & 4.383 & 10.297 & 5.914 \\
\hline 3,920 & $1,619.9$ & $4,211.8$ & $1,948,319$ & $3,780.8$ & 4.150 & 10.006 & 5.856 \\
\hline 3,820 & $1,573.5$ & $4,091.3$ & $1,892,562$ & $3,680.8$ & 3.924 & 9.720 & 5.795 \\
\hline 3,720 & $1,528.0$ & $3,973.0$ & $1,837,827$ & $3,580.8$ & 3.707 & 9.438 & 5.731 \\
\hline 3,620 & $1,483.3$ & $3,856.6$ & $1,783,995$ & $3,480.8$ & 3.498 & 9.162 & 5.664 \\
\hline 3,520 & $1,439.2$ & $3,742.1$ & $1,731,003$ & $3,380.8$ & 3.297 & 8.890 & 5.593 \\
\hline 3,420 & $1,395.8$ & $3,629.2$ & $1,678,796$ & $3,280.8$ & 3.103 & 8.622 & 5.519 \\
\hline 3,320 & $1,353.0$ & $3,517.9$ & $1,627,319$ & $3,180.8$ & 2.916 & 8.357 & 5.441 \\
\hline 3,220 & $1,310.8$ & $3,408.1$ & $1,576,522$ & $3,080.8$ & 2.736 & 8.097 & 5.360 \\
\hline $3 ; 120$ & $1,269.1$ & $3,299.7$ & $1,526,358$ & $2,980.8$ & 2.563 & 7.839 & 5.276 \\
\hline 3,020 & $1,227.8$ & $3,192.5$ & $1,476,784$ & $2,880.8$ & 2.397 & 7.584 & 5.188 \\
\hline 2,920 & $1,187.1$ & $3,086.5$ & $1,427,756$ & $2,780.8$ & 2.237 & 7.332 & 5.096 \\
\hline 2,820 & $1,146.7$ & $2,981.6$ & $1,379,236$ & $2,680.8$ & 2.083 & 7.083 & 5.000 \\
\hline 2,720 & $1,106.8$ & $2,877.7$ & $1,331,184$ & $2,580.8$ & 1.935 & 6.837 & 4.901 \\
\hline 2,620 & $1,067.2$ & $2,774.8$ & $1,283,566$ & $2,480.8$ & 1.794 & 6.592 & 4.798 \\
\hline 2,520 & $1,027.9$ & $2,672.7$ & $1,236,346$ & $2,380.8$ & 1.658 & 6.349 & 4.691 \\
\hline 2,420 & 989.0 & $2,571.4$ & $1,189,490$ & $2,280.8$ & 1.528 & 6.109 & 4.580 \\
\hline 2,320 & 950.3 & $2,470.8$ & $1,142,968$ & $2,180.8$ & 1.404 & 5.870 & 4.466 \\
\hline 2,220 & 911.9 & $2,370.9$ & $1,096,746$ & $2,080.8$ & 1.286 & 5.633 & 4.347 \\
\hline 2,120 & 873.7 & $2,271.6$ & $1,050,796$ & $1,980.8$ & 1.173 & 5.397 & 4.224 \\
\hline 2,020 & 835.7 & $2,172.8$ & $1,005,088$ & $1,880.8$ & 1.065 & 5.162 & 4.097 \\
\hline 1,920 & 797.8 & $2,074.4$ & 959,592 & $1,780.8$ & 0.963 & 4.928 & 3.965 \\
\hline 1,820 & 760.2 & $1,976.5$ & 914,281 & $1,680.8$ & 0.866 & 4.695 & 3.830 \\
\hline 1,720 & 722.6 & $1,878.9$ & 869,125 & $1,580.8$ & 0.774 & 4.464 & 3.690 \\
\hline 1,620 & 685.2 & $1,781.5$ & 824,099 & $1,480.8$ & 0.687 & 4.232 & 3.545 \\
\hline 1,520 & 647.8 & $1,684.4$ & 779,173 & $1,380.8$ & 0.606 & 4.002 & 3.395 \\
\hline 1,420 & 610.5 & $1,587.4$ & 734,320 & $1,280.8$ & 0.530 & 3.771 & 3.241 \\
\hline 1,320 & 573.3 & $1,490.6$ & 689,514 & $1,180.8$ & 0.459 & 3.541 & 3.082 \\
\hline 1,220 & 536.0 & $1,393.8$ & 644,725 & $1,080.8$ & 0.393 & 3.311 & 2.919 \\
\hline 1,120 & 498.8 & $1,296.9$ & 599,926 & 980.8 & 0.331 & 3.081 & 2.750 \\
\hline 1,020 & 461.5 & $1,200.0$ & 555,089 & 880.8 & 0.275 & 2.851 & 2.575 \\
\hline 920 & 424.2 & $1,102.9$ & 510,185 & 780.8 & 0.224 & 2.620 & 2.396 \\
\hline 820 & 386.8 & $1,005.6$ & 465,184 & 680.8 & 0.178 & 2.389 & 2.211 \\
\hline 720 & 349.2 & 908.1 & 420,056 & 580.8 & 0.137 & 2.157 & 2.020 \\
\hline 620 & 311.6 & 810.2 & 374,769 & 480.8 & 0.102 & 1.925 & 1.823 \\
\hline 520 & 273.8 & 711.9 & 329,291 & 380.8 & 0.071 & 1.691 & 1.620 \\
\hline 420 & 235.8 & 613.1 & 283,588 & 280.8 & 0.045 & 1.456 & 1.412 \\
\hline 320 & 197.6 & 513.7 & 237,626 & 180.8 & 0.024 & 1.220 & 1.196 \\
\hline 220 & 159.1 & 413.7 & 191,365 & 80.8 & 0.009 & 0.983 & 0.974 \\
\hline 120 & 120.4 & 313.0 & 144,770 & -19.2 & -0.002 & 0.743 & 0.745 \\
\hline 20 & 81.3 & 211.4 & 97,797 & -119.2 & -0.007 & 0.502 & 0.509 \\
\hline
\end{tabular}


Table 3.3. Pump Calculation for Well RRG-3

Input Parameters

Productivity index:

Static pressure at production level:

$3.3 \mathrm{gpm} / \mathrm{psi}$

Depth to production level:

1,860 psia

Density of produced water:

4,230 feet

Vapor pressure at temperature of produced water:

$57.31 \mathrm{lb} / \mathrm{ft}^{3}$

Gas partial pressure*:

67.01 psia

Pump suction pressure:

$14.65 \mathrm{psi}$

Pressure safety margin:

Relative roughness:

Casing ID:

Viscosity of produced water:

Pump discharge pressure:

Pump efficiency:

55 psi

$10 \mathrm{psi}$

0.0006 feet

8.75 inches

$0.2 \cdot \mathrm{cp}$

120 psia

Motor efficiency:

0.76

Power loss per unit length of pump shaft:

Parasitic load factor:

Temperature of produced water:

Rejection temperature:

Average specific heat of water between $\mathrm{T}$ and $\mathrm{T} 0$ :

0.88

$0 \mathrm{hp} / \mathrm{ft}$

0

$300 \quad{ }^{\circ} \mathrm{F}$

$60{ }^{\circ} \mathrm{F}$

Utilization factor:

$1 \mathrm{BTU} / \mathrm{lb} /{ }^{\circ} \mathrm{F}$

Number of wells:

Surface pipeline length:

Surface pipeline ID:

Increase in net elevation in pipeline run:

0.45

1

0 feet

0 inches

0 feet

*Based on sample of 19 May 2004: 752 ppm gas/stm @ steam fraction 0.055 
Table 3.3. Pump Calculation for Well RRG-3 (continued)

Results

\begin{tabular}{|c|c|c|c|c|c|c|c|}
\hline \multirow{2}{*}{$\begin{array}{l}\text { Depth } \\
\text { (feet) }\end{array}$} & \multirow{2}{*}{$\begin{array}{c}\text { Drawdown } \\
\text { (feet) }\end{array}$} & \multicolumn{2}{|c|}{ Flow Rate } & \multirow{2}{*}{$\begin{array}{l}\text { Head } \\
\text { (feet) }\end{array}$} & \multicolumn{3}{|c|}{ Gross } \\
\hline & & $(\mathrm{gpm})$ & $(\mathrm{lb} / \mathrm{hr})$ & & MW used & MW & Net MW \\
\hline 4,230 & $1,713.3$ & $5,654.2$ & $2,599,190$ & $4,163.0$ & 6.096 & 14.625 & 8.529 \\
\hline 4,130 & $1,660.0$ & $5,478.1$ & $2,518,232$ & $4,063.0$ & 5.764 & 14.170 & 8.406 \\
\hline 4,030 & $1,608.2$ & $5,307.3$ & $2,439,752$ & $3,963.0$ & 5.447 & 13.728 & 8.281 \\
\hline 3,930 & $1,558.0$ & $5,141.7$ & $2,363,591$ & $3,863.0$ & 5.144 & 13.299 & 8.156 \\
\hline 3,830 & $1,509.2$ & $4,980.5$ & $2,289,526$ & $3,763.0$ & 4.854 & 12.883 & 8.029 \\
\hline 3,730 & $1,461.7$ & $4,823.6$ & $2,217,380$ & $3,663.0$ & 4.576 & 12.477 & 7.901 \\
\hline 3,630 & $1,415.3$ & $4,670.5$ & $2,146,991$ & $3,563.0$ & 4.309 & 12.081 & 7.771 \\
\hline 3,530 & $1,369.9$ & $4,520.9$ & $2,078,217$ & $3,463.0$ & 4.054 & 11.694 & 7.639 \\
\hline 3,430 & $1,325.6$ & $4,374.5$ & $2,010,926$ & $3,363.0$ & 3.810 & 11.315 & 7.505 \\
\hline 3,330 & $1,282.1$ & $4,231.1$ & $1,945,001$ & $3,263.0$ & 3.575 & 10.944 & 7.369 \\
\hline 3,230 & $1,239.5$ & $4,090.4$ & $1,880,333$ & $3,163.0$ & 3.351 & 10.580 & 7.230 \\
\hline 3,130 & $1,197.6$ & $3,952.2$ & $1,816,822$ & $3,063.0$ & 3.135 & 10.223 & 7.088 \\
\hline 3,030 & $1,156.5$ & $3,816.4$ & $1,754,377$ & $2,963.0$ & 2.928 & 9.872 & 6.943 \\
\hline 2,930 & $1,115.9$ & $3,682.7$ & $1,692,913$ & $2,863.0$ & 2.730 & 9.526 & 6.795 \\
\hline 2,830 & $1,076.0$ & $3,550.9$ & $1,632,349$ & $2,763.0$ & 2.541 & 9.185 & 6.644 \\
\hline 2,730 & $1,036.8$ & $3,421.5$ & $1,572,863$ & $2,663.0$ & 2.360 & 8.850 & 6.491 \\
\hline 2,630 & 997.9 & $3,293.3$ & $1,513,901$ & $2,563.0$ & 2.186 & 8.518 & 6.333 \\
\hline 2,530 & 959.5 & $3,166.5$ & $1,455,626$ & $2,463.0$ & 2.020 & 8.191 & 6.171 \\
\hline 2,430 & 921.5 & $3,041.1$ & $1,397,977$ & $2,363.0$ & 1.861 & 7.866 & 6.005 \\
\hline 2,330 & 883.9 & $2,916.9$ & $1,340,893$ & $2,263.0$ & 1.709 & 7.545 & 5.835 \\
\hline 2,230 & 846.6 & $2,793.9$ & $1,284,317$ & $2,163.0$ & 1.565 & 7.227 & 5.662 \\
\hline 2,130 & 809.6 & $2,671.8$ & $1,228,193$ & $2,063.0$ & 1.427 & 6.911 & 5.483 \\
\hline 2,030 & 772.9 & $2,550.5$ & $1,172,469$ & $1,963.0$ & 1.297 & 6.597 & 5.301 \\
\hline 1,930 & 736.4 & $2,430.1$ & $1,117,091$ & $1,863.0$ & 1.172 & 6.286 & 5.113 \\
\hline 1,830 & 700.1 & $2,310.3$ & $1,062,011$ & $1,763.0$ & 1.055 & 5.976 & 4.921 \\
\hline 1,730 & 663.9 & $2,191.0$ & $1,007,179$ & $1,663.0$ & 0.944 & 5.667 & 4.724 \\
\hline 1,630 & 627.9 & $2,072.1$ & 952,544 & $1,563.0$ & 0.839 & 5.360 & 4.521 \\
\hline 1,530 & 592.0 & $1,953.6$ & 898,059 & $1,463.0$ & 0.740 & 5.053 & 4.313 \\
\hline 1,430 & 556.1 & $1,835.3$ & 843,675 & $1,363.0$ & 0.648 & 4.747 & 4.099 \\
\hline 1,330 & 520.3 & $1,717.1$ & 789,342 & $1,263.0$ & 0.562 & 4.441 & 3.880 \\
\hline 1,230 & 484.5 & $1,598.9$ & 735,013 & $1,163.0$ & 0.482 & 4.136 & 3.654 \\
\hline 1,130 & 448.7 & $1,480.6$ & 680,635 & $1,063.0$ & 0.408 & 3.830 & 3.422 \\
\hline 1,030 & 412.8 & $1,362.1$ & 626,158 & 963.0 & 0.340 & 3.523 & 3.184 \\
\hline 930 & 376.7 & $1,243.3$ & 571,529 & 863.0 & 0.278 & 3.216 & 2.938 \\
\hline 830 & 340.6 & $1,124.0$ & 516,692 & 763.0 & 0.222 & 2.907 & 2.685 \\
\hline 730 & 304.3 & $1,004.1$ & 461,590 & 663.0 & 0.172 & 2.597 & 2.425 \\
\hline 630 & 267.7 & 883.5 & 406,162 & 563.0 & 0.129 & 2.285 & 2.157 \\
\hline 530 & 230.9 & 762.1 & 350,344 & 463.0 & 0.091 & 1.971 & 1.880 \\
\hline 430 & 193.8 & 639.7 & 294,069 & 363.0 & 0.060 & 1.655 & 1.595 \\
\hline 330 & 156.4 & 516.1 & 237,263 & 263.0 & 0.035 & 1.335 & 1.300 \\
\hline 230 & 118.5 & 391.2 & 179,838 & 163.0 & 0.017 & 1.012 & 0.995 \\
\hline 130 & 80.2 & 264.8 & 121,731 & 63.0 & 0.004 & 0.685 & 0.681 \\
\hline 30 & 41.4 & 136.7 & 62,831 & -37.0 & -0.001 & 0.354 & 0.355 \\
\hline
\end{tabular}

GeothermEx, Inc. 2004 
Table 3.4. Pump Calculation for Well RRG-5

Input Parameters

Productivity index:

Static pressure at production level:

Depth to production level:

Density of produced water:

Vapor pressure at temperature of produced water:

Gas partial pressure*:

Pump suction pressure:

Pressure safety margin:

Relative roughness:

Casing ID:

Viscosity of produced water:

Pump discharge pressure:

Pump efficiency:

Motor efficiency:

Power loss per unit length of pump shaft:

Parasitic load factor:

Temperature of produced water:

Rejection temperature:

Average specific heat of water between $\mathrm{T}$ and $\mathrm{T} 0$ :

Utilization factor:

Number of wells:

Surface pipeline length:

Surface pipeline ID:

Increase in net elevation in pipeline run:

$2.9 \mathrm{gpm} / \mathrm{psi}$

1,560 psia

3,490 feet

$58.16 \mathrm{lb} / \mathrm{ft}^{3}$

43.25 psia

$2.18 \mathrm{psi}$

67 psi

$10 \mathrm{psi}$

0.0006 feet

8.75 inches

$0.2 \mathrm{cp}$

80 psia

0.76

0.88

$0 \mathrm{hp} / \mathrm{ft}$

0

$272{ }^{\circ} \mathrm{F}$

$60{ }^{\circ} \mathrm{F}$

$1 \mathrm{BTU} / \mathrm{lb} /{ }^{\circ} \mathrm{F}$

0.45

1

0 feet

0 inches

0 feet

*Maximum likely value, based on $\mathrm{CO}_{2} / \mathrm{stm}=10 \mathrm{mg} / \mathrm{kg}, \mathrm{N}_{2} / \mathrm{stm}=35 \mathrm{mg} / \mathrm{kg}$ (actual gases in 2004 were " $<$ DL of 30 ppm", but data from 1970s imply possibly $30-40 \mathrm{ppm}$, to maybe $60 \mathrm{ppm}$ ) 
Table 3.4. Pump Calculation for Well RRG-5 (continued)

Results

\begin{tabular}{|c|c|c|c|c|c|c|c|}
\hline \multirow{2}{*}{$\begin{array}{c}\text { Depth } \\
\text { (feet) }\end{array}$} & \multirow{2}{*}{$\begin{array}{c}\text { Drawdown } \\
\text { (feet) }\end{array}$} & \multicolumn{2}{|c|}{ Flow Rate } & \multirow{2}{*}{$\begin{array}{l}\text { Head } \\
\text { (feet) }\end{array}$} & \multicolumn{3}{|c|}{ Gross } \\
\hline & & (gpm) & $(\mathrm{lb} / \mathrm{hr})$ & & MW used & MW & Net MW \\
\hline 3,490 & $1,437.6$ & $4,169.1$ & $1,944,919$ & $3,384.9$ & 3.709 & 8.768 & 5.060 \\
\hline 3,390 & $1,389.7$ & $4,030.3$ & $1,880,182$ & $3,284.9$ & 3.479 & 8.477 & 4.997 \\
\hline 3,290 . & $1,342.9$ & $3,894.4$ & $1,816,796$ & $3,184.9$ & 3.260 & 8.191 & 4.931 \\
\hline 3,190 & $1,296.9$ & $3,761.1$ & $1,754,592$ & $3,084.9$ & 3.049 & 7.910 & 4.861 \\
\hline 3,090 & $1,251.8$ & $3,630.2$ & $1,693,551$ & $2,984.9$ & 2.848 & 7.635 & 4.787 \\
\hline 2,990 & $1,207.4$ & $3,501.6$ & $1,633,555$ & $2,884.9$ & 2.655 & 7.365 & 4.710 \\
\hline 2,890 & $1,163.8$ & $3,375.1$ & $1,574,523$ & $2,784.9$ & 2.470 & 7.099 & 4.628 \\
\hline 2,790 & $1,120.8$ & $3,250.5$ & $1,516,379$ & $2,684.9$ & 2.294 & 6.836 & 4.543 \\
\hline 2,690 & $1,078.4$ & $3,127.6$ & $1,459,052$ & $2,584.9$ & 2.125 & 6.578 & 4.453 \\
\hline 2,590 & $1,036.6$ & $3,006.3$ & $1,402,476$ & $2,484.9$ & 1.963 & 6.323 & 4.360 \\
\hline 2,490 & 995.3 & $2,886.5$ & $1,346,588$ & $2,384.9$ & 1.809 & 6.071 & 4.262 \\
\hline 2,390 & 954.5 & $2,768.1$ & $1,291,331$ & $2,284.9$ & 1.662 & 5.822 & 4.160 \\
\hline 2,290 & 914.1 & $2,650.8$ & $1,236,649$ & $2,184.9$ & 1.522 & 5.575 & 4.053 \\
\hline 2,190 & 874.0 & $2,534.7$ & $1,182,490$ & $2,084.9$ & 1.389 & 5.331 & 3.942 \\
\hline 2,090 & 834.3 & $2,419.7$ & $1,128,803$ & $1,984.9$ & 1.262 & 5.089 & 3.827 \\
\hline 1,990 & 795.0 & $2,305.5$ & $1,075,540$ & $1,884.9$ & 1.142 & 4.849 & 3.707 \\
\hline 1,890 & 755.9 & $2,192.1$ & $1,022,654$ & $1,784.9$ & 1.028 & 4.611 & 3.582 \\
\hline 1,790 & 717.0 & $2,079.5$ & 970,101 & $1,684.9$ & 0.921 & 4.374 & 3.453 \\
\hline 1,690 & 678.4 & $1,967.4$ & 917,837 & $1,584.9$ & 0.820 & 4.138 & 3.318 \\
\hline 1,590 & 640.0 & $1,855.9$ & 865,819 & $1,484.9$ & 0.724 & 3.903 & 3.179 \\
\hline 1,490 & 601.7 & $1,744.9$ & 814,004 & $1,384.9$ & 0.635 & 3.670 & 3.035 \\
\hline 1,390 & 563.5 & $1,634.2$ & 762,352 & $1,284.9$ & 0.552 & 3.437 & 2.885 \\
\hline 1,290 & 525.4 & $1,523.7$ & 710,820 & $1,184.9$ & 0.474 & 3.205 & 2.730 \\
\hline 1,190 & 487.4 & $1,413.4$ & 659,369 & $1,084.9$ & 0.403 & 2.973 & 2.570 \\
\hline 1,090 & 449.4 & $1,303.2$ & 607,956 & 984.9 & 0.337 & 2.741 & 2.404 \\
\hline 990 & 411.4 & $1,193.0$ & 556,540 & 884.9 & 0.277 & 2.509 & 2.232 \\
\hline 890 & 373.3 & $1,082.7$ & 505,079 & 784.9 & 0.223 & 2.277 & 2.054 \\
\hline 790 & 335.2 & 972.2 & 453,529 & 684.9 & 0.175 & 2.045 & 1.870 \\
\hline 690 & 297.0 & 861.4 & 401,847 & 584.9 & 0.132 & 1.812 & 1.679 \\
\hline 590 & 258.7 & 750.2 & 349,986 & 484.9 & 0.096 & 1.578 & 1.482 \\
\hline 490 & 220.2 & 638.6 & 297,902 & 384.9 & 0.065 & 1.343 & 1.278 \\
\hline 390 & 181.5 & 526.3 & 245,543 & 284.9 & 0.039 & 1.107 & 1.068 \\
\hline 290 & 142.5 & 413.4 & 192,858 & 184.9 & 0.020 & 0.869 & 0.849 \\
\hline 190 & 103.3 & 299.7 & 139,795 & 84.9 & 0.007 & 0.630 & 0.624 \\
\hline 90 & 63.8 & 185.0 & 86,295 & -15.1 & -0.001 & 0.389 & 0.390 \\
\hline
\end{tabular}


Table 3.5. Results of Pressure Build-up Data Analysis

\begin{tabular}{|l|c|c|c|c|}
\hline Well & $\begin{array}{c}\text { Reservoir Flow } \\
\text { Capacity (md-ft) }\end{array}$ & Skin Factor & Match Quality & $\frac{\text { Pseudo Skin }}{\text { Factor* }}$ \\
\hline RRG-1 & 34,000 & 2.2 & Good & 2.2 \\
\hline RRG-2 & 11,500 & -5.1 & Questionable & 4.7 \\
\hline RRG-3 & 4,000 & -7.3 & Questionable & 1.9 \\
\hline RRG-4 & 3,200 & -3.5 & Good & - \\
\hline RRG-5 & \multicolumn{3}{|c|}{ Uninterpretable } & 3.3 \\
\hline
\end{tabular}

* Assuming a flow capacity of $34,000 \mathrm{md}-\mathrm{ft}$. 
Table 4.1. Chemical Analyses of Water Samples from Raft River Well Tests 2004 - part 1

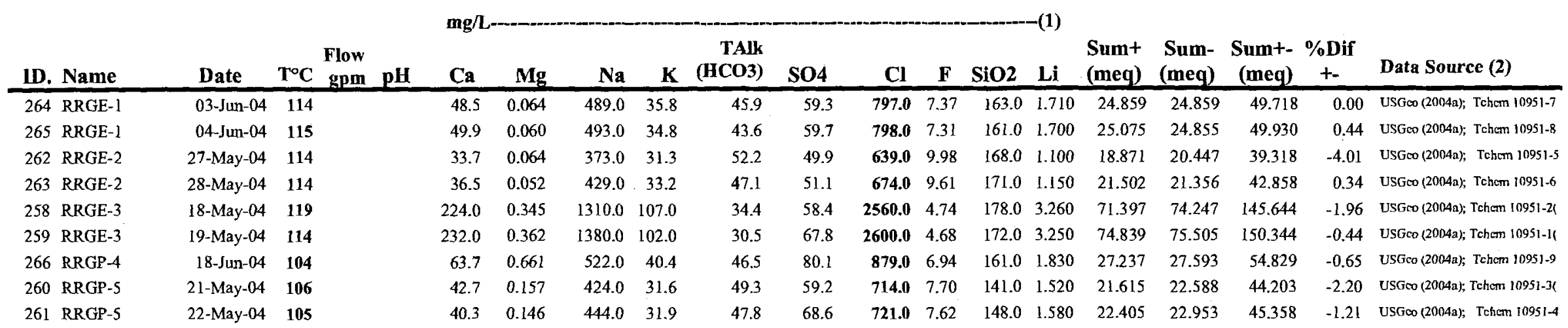

Notes:

1) A negtive sign on an $\mathrm{mg} / \mathrm{L}$ value indicates less than (i.e. less than detection limit).

2) Citations in this part of table may be truncated. See complete citations and list of references in part 3 . 
Table 4.1. Chemical Analyses of Water Samples from Raft River Well Tests 2004 - part 2

\begin{tabular}{|c|c|c|c|c|c|c|c|c|c|c|c|c|}
\hline \multirow{2}{*}{\multicolumn{2}{|c|}{ ID. Name }} & \multicolumn{8}{|c|}{ 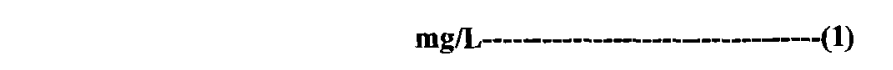 } & \multirow{2}{*}{$\begin{array}{r}\text { Ec } \\
\text { micro-S } \\
\end{array}$} & \multirow{2}{*}{$\begin{array}{l}\text { Stable Isotopes } \\
\text { o/oo (SMOW) } \\
\text { dD d180 }\end{array}$} & \multirow[b]{2}{*}{ Data Source (2) } \\
\hline & & Date & $\mathbf{T}^{\circ} \mathbf{C}$ & Map location & $\mathrm{Cl}$ & $\mathbf{F e}$ & B & As & $\mathrm{Sr}$ & & & \\
\hline 264 & RRGE-1 & 03-Jun-04 & 114 & & 797 & & 0.21 & & & & & USGeo (2004a); Tchem 10951-7(Aug 9/04); Tchem 10960-5 (Aug 9/04) \\
\hline 265 & RRGE-I & 04-Jun-04 & 115 & & 798 & & 0.29 & & & & & USGeo (2004a); Tchem 10951-8(Aug 9/04); Tchem 10960-6 (Aug 9/04) \\
\hline & RRGE-2 & 27-May-04 & 114 & & 639 & & 0.18 & & & & & USGeo (2004a); Tchem 10951-5(Aug 9/04); Tchem 10960-3 (Aug 9/04) \\
\hline & RRGE-2 & 28-May-04 & 114 & & 674 & & 0.22 & & & & & USGeo (2004a); Tchem 10951-6(Aug 9/04); Tchem 10960-4 (Aug 9/04) \\
\hline & RRGE-3 & 18-May-04 & 119 & $15 S-26 \mathrm{E}-25 \mathrm{bdal}$ & 2560 & & 0.52 & & & & & USGeo (2004a); Tchem 10951-2(Aug 9/04); Tchem 10960-1 (Aug 9/04) \\
\hline & RRGE-3 & 19-May-04 & 114 & 15S-26E-25bdal & 2600 & -0.31 & 0.49 & 0.01 & 5.47 & & & USGeo (2004a); Tchem 10951-1(Aug 9/04); Tchem 10952-1 (Aug 9/04) \\
\hline & RRGP-4 & 18-Jun-04 & 104 & & 879 & & 0.33 & & & & & USGeo (2004a); Tchem 10951-9(Aug 9/04); Tchem 10960-7 (Aug 9/04) \\
\hline & RRGP-5 & 21-May-04 & 106 & & 714 & & 0.20 & & & & & USGeo (2004a); Tchem 10951-3(Aug 9/04); Tchem 10960-2 (Aug 9/04) \\
\hline 261 & RRGP-5 & 22-May-04 & 105 & & 721 & -0.31 & 0.20 & 0.00 & 1.06 & & & USGeo (2004a); Tchem 1095!-4(Aug 9/04); Tchem 10952-2(Aug 9/04) \\
\hline
\end{tabular}

Notes:

1) A negtive sign on an $\mathrm{mg} / \mathrm{L}$ value indicates less than (i.e. less than detection limit).

2) Citations in this part of table may be truncated. See complete citations and list of references in part 3. 

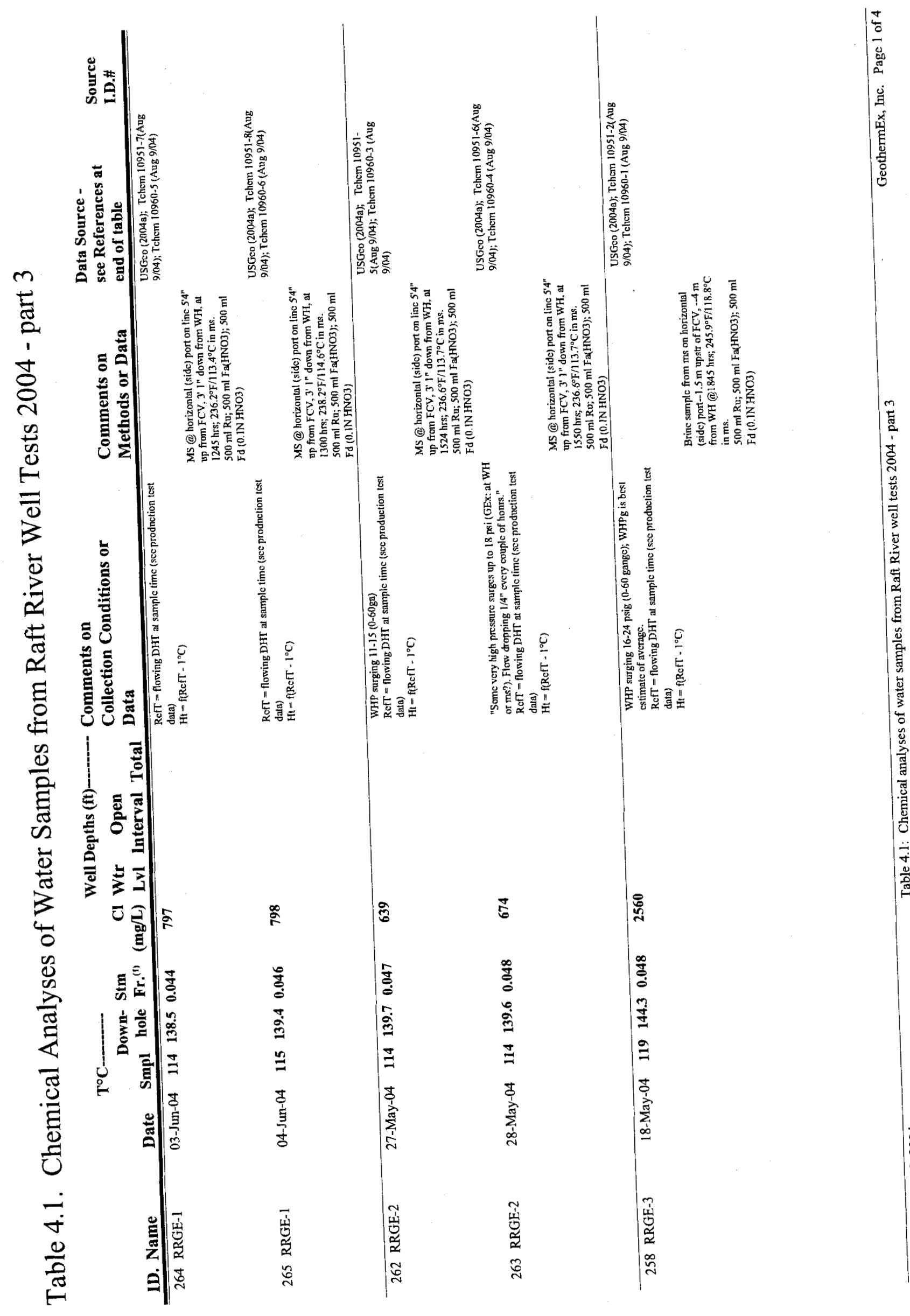
Table 4.1: Chemical analyses of water samples from Raft River well tests 2004 - part 3

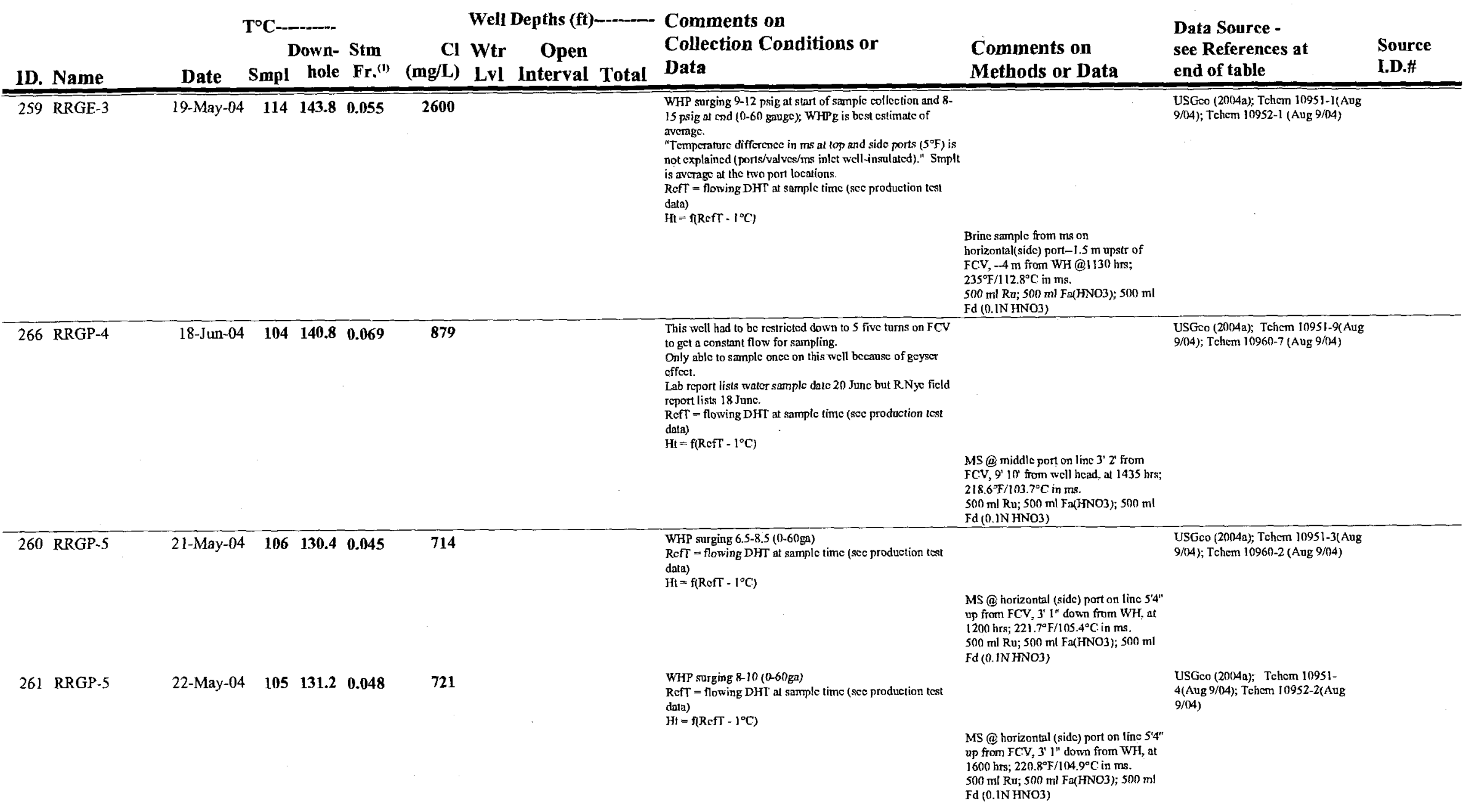


Table 4.1: Chemical analyses of water samples from Raft River well tests 2004 - part 3

\begin{tabular}{|c|c|c|c|c|c|c|c|c|c|c|c|}
\hline \multirow[b]{2}{*}{ 1D. Name } & \multirow[b]{2}{*}{ Date } & \multicolumn{2}{|c|}{ T'C-.-...- } & \multirow[b]{2}{*}{$\begin{array}{l}\text { Stm } \\
\text { Fr. }^{(1)}\end{array}$} & \multicolumn{3}{|c|}{ Well Depths (ft) } & \multirow{2}{*}{$\begin{array}{l}\text { Comments on } \\
\text { Collection Conditions or } \\
\text { Data }\end{array}$} & \multirow[b]{2}{*}{$\begin{array}{l}\text { Comments on } \\
\text { Methods or Data }\end{array}$} & \multirow[b]{2}{*}{$\begin{array}{l}\text { Data Source - } \\
\text { see References at } \\
\text { end of table }\end{array}$} & \multirow[b]{2}{*}{$\begin{array}{l}\text { Source } \\
\text { I.D.\# }\end{array}$} \\
\hline & & Smpl & $\begin{array}{l}\text { own- } \\
\text { hole }\end{array}$ & & $\begin{array}{r}\mathrm{Cl} \\
(\mathrm{mg} / \mathrm{L})\end{array}$ & $\begin{array}{lr}\text { Wtr } & \text { Open } \\
\text { Lvl Interval }\end{array}$ & Total & & & & \\
\hline
\end{tabular}

(1) Steam fraction at Sample temperature, calculated using total flow enthalpy

\section{References (to entire Raft River chemistry database)}

Allen \& Chaney (1979) Allen, C.A. and RE. Chaney, 1979. Geochemical modeling at Raft River. Geothermal Resources Council, Transactions, Vol. 3, pp. 1-4.

Allen (1977) Allen, 1977. Preliminary chemical evaluation of the Raft River area - CAA-G02-77. EG\&G Idaho interoffice correspondence, C.A. Allen to R.C. Stoker, 8 April 1977. 19 pages including tables and figures. Note: the document contains inconsistent values for alkalinity and some values have an unclear basis (as caco3 or as hco3?)

Campbell et al. (1981) Campbell, D.A., A.R Sinclair, R.J. Hanold and O.J. Vetter, 1981. A review of the geothermal reservoir well stimulation program. Proceedings, International Conference on Geothermal Drilling and Completion Technology, January 21-23, 1981, Albuquerque, NM. Sandia National Labortory, SNL Report \#SAND 81-0036C.

Crosthwaite (1976) Crosthwaite, E.G., 1976. Basic data from 5 core holes, Raft River geothermal area, Cassia County, ldaho. U.S. Geological Survey Open-File Report 76-665.

Dolenc et al. (1981) Dolenc, M.R. L.C. Hull, S.A. Mizell and others, 1981. Raft River Geoscience Case Study. EG\&G ldaho, EGG-2125. Prepared for the U.S. Department of Energy, Idaho Operations Office and ldaho National Engineering Laboratory. Volume 1 (145 pages) and Volume 11 (Appendices, 158 pages). Chemical data are in Table 32 and in Appendix D.

Kunze and Turner (1979) Kunze, J.F. and J.R. Turner, 1979. An evaluation of reservoir engineering and the fluid supply and injection system of the Raft River geothermal pilot plant, Tasks 2.2 and 7.0. U.S. Department of Energy contract DE-AC07-791D11802 with the Geothermal Power Development Group, June 27, 1979-Revised July 27, 1979. Prepared by Jay F. Kunze, Consultant and James R. Turner, ldaho Power Co., assisted by Don Carson, Raft River Rural Electric Cooperative, Inc.

McAtee \& Williams (1978a McAtee, R.E. and R.L. Williams, 1978a. Results, chemical data evaluation from the flow test on RRGI-6, test plan FET-12A-78. Photocopy of report from November 9, 1978 flow test. No date. 3 pages including table.

McAtee \& Williams (1979a McAtee, R.E. and R.L. Williams, 1979a. Results, chemical data from the flow test on RRGP-4AB, test plan FET-10B-78. Photocopy, EG\&G interoffice correspondence, R.E. McAtee to D. Goldman, January 5, 1979. 5 pages including table and cover.

McAtce \& Williams (1979b McAtee, R.E. and R.L. Williams, 1979b. Results, chemical data collected during the 18-hour flow test of RRGP-5, FET-14A-78. Photocopy, EG\&G interoffice correspondence, R.E. McAtee to D. Goldman, January 5, 1979. 4 pages including table and cover.

McAtee \& Williams (1979c McAtee, R.E. and R.L. Williams, 1979c. Results, chemical data evaluation from the flow well RRGE-2, injecting in well RRGl-6 for 72 -hours, test plan FET-22B-79. Photocopy of report from November 10-12, 1979 flow test. No date. 6 pages including table and figure.

Nathenson et al (1982) Nathenson, M., N.L. Nehring, E.G. Crosthwaite, R.S. Harmon, C. Janik and J. Borthwick, 1982. Chemical and light-stable isotope characteristics of waters from the Raft River geothernal area and environs, Cassia County, 1dahn; Box Elder County, Utah Geothermics, Vol.11, No.4, pp. 215-237.

Nathenson et.al. (1980) Nathenson, M., T.C. Urban, W. H. Diment and N.L. Nehring, 1980. Temperatures, heat flow, and water chemistry from drill holes in the Raft River geothermal system, Cassia County, Idaho. U.S. Geological Survey Open-File Report 80-2001.

Overton et al. (1979) Overton, H.L., R.E. Chaney, RE. McAtee and D.L. Graham, 1979. Geochemical modeling of the Raft River geothermal field EG\&G ldaho, EGG-2004, UC-66B. Prepared for the U.S.Department of Energy, ldaho Operations Office and ldaho National Engineering Laboratory. 


\section{Table 4.1: Chemical analyses of water samples from Raft River well tests 2004 - part 3}

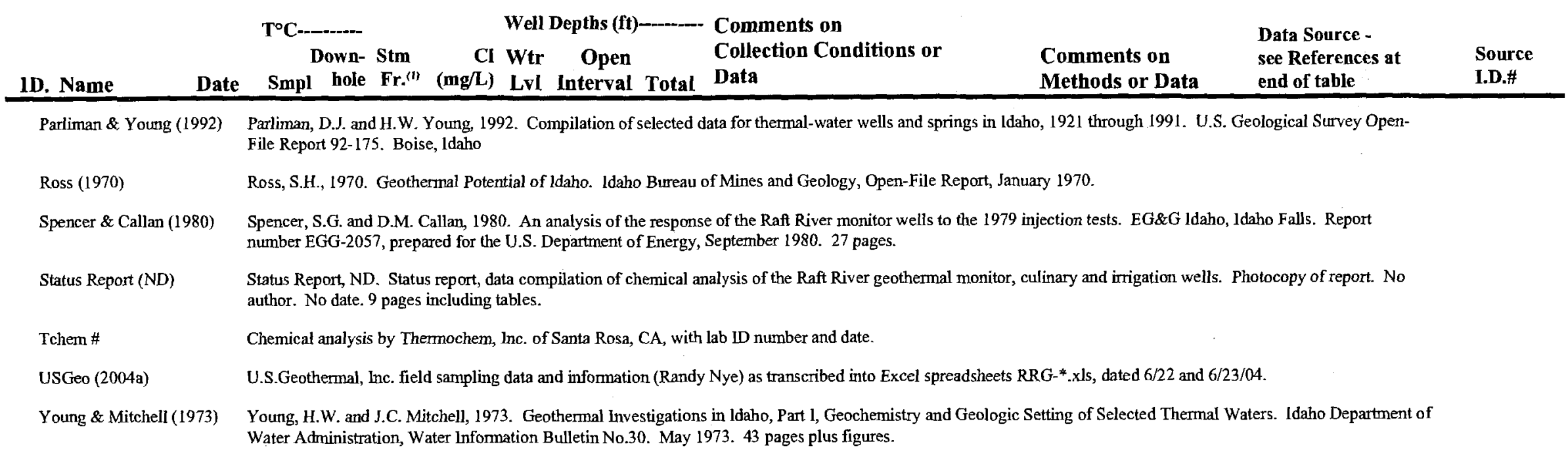




\section{Table 4.2. Aqueous Geothermometry of Samples from Raft River - Tests of 2004}

\begin{tabular}{|c|c|c|c|c|c|c|c|c|c|c|c|c|c|c|c|c|c|c|c|c|}
\hline \multirow[b]{3}{*}{ ID. } & \multirow[b]{3}{*}{ Name } & \multirow[b]{3}{*}{ Date } & \multicolumn{13}{|c|}{ Geothermometers, ${ }^{\circ} \mathrm{C}^{(1)}$} & \multirow{2}{*}{\multicolumn{2}{|c|}{$\begin{array}{c}\text { Na-K-Ca-Mg } \\
4^{\circ}-340^{\circ}\end{array}$}} & \multirow{3}{*}{$\begin{array}{c}\mathrm{Na} / \mathrm{K} \\
(\mathrm{F}) \\
>150^{\circ}\end{array}$} & \multirow{3}{*}{ 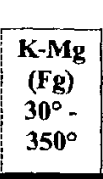 } & \multirow[b]{3}{*}{ Comments } \\
\hline & & & \multicolumn{3}{|c|}{ Flow $\quad \mathrm{T}^{\circ} \mathrm{C}-$} & \multirow[b]{2}{*}{$\begin{array}{c}\mathrm{Cl} \\
\mathrm{mg} / \mathrm{l}\end{array}$} & \multicolumn{2}{|c|}{$\begin{array}{c}\text { Quartz } \\
0^{\circ}-330^{\circ}\end{array}$} & \multicolumn{2}{|c|}{$\begin{array}{c}\text { Chalcedony } \\
0^{\circ}-250^{\circ}\end{array}$} & \multirow{2}{*}{$\begin{array}{l}\text { Amor } \\
0^{\circ}- \\
250^{\circ}\end{array}$} & \multicolumn{2}{|c|}{$\mathrm{Na}-\mathrm{K}-\mathrm{Ca}$} & \multicolumn{2}{|c|}{$4^{\circ}-340^{\circ}$} & & & & & \\
\hline & & & $\begin{array}{l}\text { Flow } \\
\text { gpm }\end{array}$ & Smpl & $\begin{array}{l}\text { Down- } \\
\text { hole }\end{array}$ & & $\begin{array}{l}0^{\circ}-3 \\
\text { Con. }\end{array}$ & $\begin{array}{l}30^{\circ} \\
\text { Ad. }\end{array}$ & Con. & Ad. & & $\begin{array}{l}\text { SQ- } \\
\text { CaNa }\end{array}$ & $\begin{array}{l}B= \\
4 / 3\end{array}$ & $\begin{array}{l}B= \\
1 / 3\end{array}$ & \begin{tabular}{|l|} 
Final \\
Temp \\
\end{tabular} & $\begin{array}{c}\text { R- } \\
\text { factor }\end{array}$ & \begin{tabular}{|l|l} 
Final \\
Temp
\end{tabular} & & & \\
\hline 264 & RRGE-I & 03-Jun-04 & & 114 & 139 & 797 & 167 & 159 & 143 & 137 & 44 & 1.64 & 150 & 175 & 175 & 0 & 175 & 192 & 175 & $\begin{array}{l}\text { RefT = flowing DHT at sample time (sec } \\
\text { production lest data) } \\
\left.\text { Hit }=\text { f(RefT }-1^{\circ} \mathrm{C}\right)\end{array}$ \\
\hline 265 & RRGE-1 & 04-Jun-04 & & 115 & 139 & 798 & 166 & 158 & 142 & 136 & 43 & 1.65 & 148 & 173 & 173 & 0 & 173 & 189 & 175 & 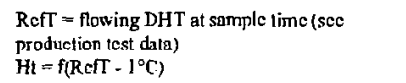 \\
\hline 262 & RRGE-2 & 27-May-04 & & 114 & 140 & 639 & 169 & 161 & 146 & 138 & 45 & 1.79 & 151 & 180 & 180 & 0 & 180 & 202 & 170 & 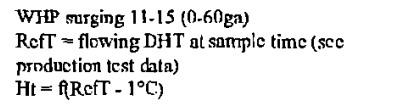 \\
\hline 263 & RRGE-2 & 28-May-04 & & 114 & 140 & 674 & 170 & 162 & 147 & 140 & 46 & 1.62 & 153 & 178 & 178 & 0 & 178 & 196 & 176 & 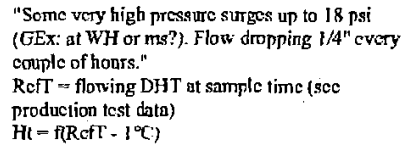 \\
\hline 258 & RRGE-3 & 18-May-04 & & 119 & 144 & 2560 & 173 & 164 & 150 & 142 & 49 & 1.31 & 170 & 185 & 185 & 0 & 185 & 200 & 185 & 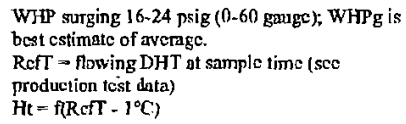 \\
\hline 259 & RRGE-3 & 19-May-04 & & 114 & 144 & 2600 & 170 & 162 & 147 & 140 & 47 & 1.27 & 167 & 180 & 180 & 0 & 180 & 192 & 182 & 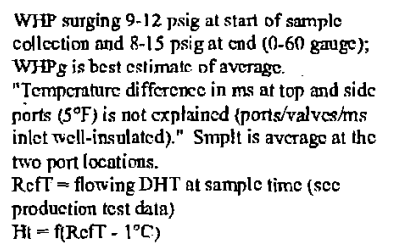 \\
\hline 266 & RRGP.4 & 18-Jun-04 & & 104 & 141 & 879 & 166 & 158 & 142 & 136 & 43 & 1.76 & 148 & 176 & 176 & 1 & 176 & 196 & 139 & 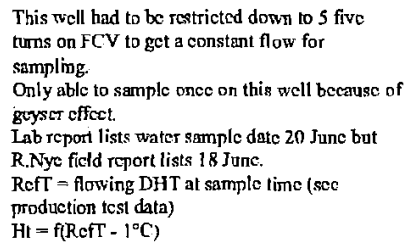 \\
\hline 260 & RRGP-5 & 21-May-04 & & 106 & 130 & 714 & 158 & 151 & 133 & 128 & 35 & 1.77 & 146 & 174 & 174 & 0 & 174 & 193 & 155 & 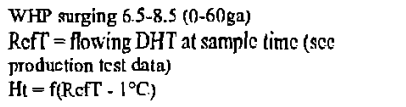 \\
\hline 261 & RRGP-5 & 22-May-04 & & 105 & 131 & 721 & 161 & 154 & 136 & 131 & 38 & 1.64 & 149 & 174 & 174 & 0 & 174 & 190 & 156 & $\begin{array}{l}\text { WHP surging 8-10 (20-60ga) } \\
\text { RefT = flowing DHT at sample time (sce } \\
\text { production tost data) } \\
\text { Ht }=\text { f(RefT }-1^{\circ} \mathrm{C} \text { ) }\end{array}$ \\
\hline
\end{tabular}




\section{Table 4.2 : Aqueous geothermometry of samples from Raft River - tests of 2004}

\begin{tabular}{|c|c|c|c|c|c|c|c|c|c|c|c|c|c|c|c|c|c|c|}
\hline \multirow[b]{3}{*}{ ID. Name } & \multirow[b]{3}{*}{ Date } & \multicolumn{8}{|c|}{ Geothermometers, ${ }^{\circ} \mathrm{C}^{(1)}$} & & & & & \multirow{2}{*}{\multicolumn{2}{|c|}{\begin{tabular}{|c|} 
Na-K-Ca-Mg \\
$4^{\circ}-340^{\circ}$ \\
\end{tabular}}} & \multirow{3}{*}{$\begin{array}{c}\mathbf{N a} / \mathbf{K} \\
(\mathbf{F}) \\
>150^{\circ}\end{array}$} & \multirow{3}{*}{$\begin{array}{c}\text { K-Mg } \\
\text { (F } \mathbf{F g}) \\
30^{\circ}- \\
350^{\circ}\end{array}$} & \multirow[b]{3}{*}{ Comments } \\
\hline & & \multicolumn{3}{|c|}{$\mathbf{T}^{\circ} \mathrm{C}$} & \multirow[b]{2}{*}{$\underset{\mathrm{mg} / \mathrm{l}}{\mathrm{Cl}}$} & \multirow{2}{*}{$\begin{array}{c}\text { Quartz } \\
0^{\circ}-\mathbf{3 3 0}\end{array}$} & \multirow{2}{*}{\multicolumn{2}{|c|}{$\begin{array}{l}\text { Chalcedony } \\
0^{\circ}-250^{\circ} \\
\text { Con. Ad. }\end{array}$}} & \multirow{2}{*}{$\begin{array}{c}\text { Amor } \\
0^{\circ}- \\
250^{\circ}\end{array}$} & \multicolumn{2}{|c|}{$\mathrm{Na}-\mathrm{K}-\mathrm{Ca}$} & \multicolumn{2}{|c|}{$4^{\circ}-340^{\circ}$} & & & & & \\
\hline & & $\begin{array}{l}\text { Flow } \\
\text { gpm }\end{array}$ & Smpl & $\begin{array}{l}\text { Down- } \\
\text { hole }\end{array}$ & & & & & & $\begin{array}{c}\mathrm{SQ}- \\
\mathrm{CaNa}\end{array}$ & $\begin{array}{l}B= \\
4 / 3\end{array}$ & $\begin{array}{l}B= \\
1 / 3\end{array}$ & $\begin{array}{l}\text { Final } \\
\text { Temp }\end{array}$ & $\begin{array}{c}R- \\
\text { factor }\end{array}$ & $\begin{array}{l}\text { Final } \\
\text { Temp }\end{array}$ & & & \\
\hline
\end{tabular}

\section{References:}

1) Henley, R.W., Truesdell, A.H., Barton, P.B.Jr., 1984, Fluid-Mineral Equilibria in Hydrothermal Systems. Reviews in Economic Geology, Vol.1. Society of Economic Geologists. The Economic Geology Publishing Company, El Paso Texas USA.

Quarta: quartz geothermometer of Foumier and Potter Con. $=$ conductive

Ad. $=$ adiabatic, for waters boiling at $100^{\circ} \mathrm{C}$

Chalcedony: chalcedony geothermometer of Fournier Con. $=$ conductive

Ad. = adiabatic, for waters boiling at $100^{\circ} \mathrm{C}$

Amor (amorphous silica): amorphous silica geothermometer of Fournier

Na-K-Ca: Na-K-Ca geothermometer of Fournier and Trusdell

$\mathrm{SQ}-\mathrm{CaNa}=$ factor square $\operatorname{root}(\mathrm{Ca}) / \mathrm{Na}$

$B 13=$ temperature for factor $B=4 / 3$

$\mathrm{B} 43=$ temperature for factor $\mathrm{B}=1 / 3$

Final Temperature $=\mathrm{B} 43$ or B13, according to rules for B and SQ-CaNa

Na-K-Ca-Mg: Na-K-Ca-Mg geothermometer of Foumier and Truesdell

Factor $\mathrm{R}(\mathrm{Mg}, \mathrm{K}, \mathrm{Ca})=$ relative concentration of $\mathrm{Mg}$, the applicable range is $5-50$.

Final Temperature = final result, according to rules for application of Factor $R$.

$\mathrm{Na}-\mathrm{K}(\mathrm{F}): \mathrm{Na} / \mathrm{K}$ geothermometer of Fournier

2) Fournier, R.O., 1990, The interpretation of Na-K-Mg relations in geothermal waters. Geothermal Resources Council Transactions, vol.14, part II, pp. 1421 - 1425. August 1990.

$\mathrm{K}-\mathrm{Mg}(\mathrm{Fg}): \mathrm{K}-\mathrm{Mg}$ geothermometer of Fournier (equations corrected by GeothermEx) 


\section{Table 4.3. Raft River - Analyses of Gases in Steam ${ }^{(1)(2)}$}

\begin{tabular}{|c|c|c|c|c|c|c|c|c|c|c|c|c|c|c|c|c|}
\hline \multirow{2}{*}{ Name } & \multirow{2}{*}{$\begin{array}{l}\text { Date } \\
\text { Time }\end{array}$} & \multirow{2}{*}{$\begin{array}{l}\text { WHP } \\
\text { psig }\end{array}$} & \multirow{2}{*}{$\begin{array}{c}S m p l \\
T^{\circ} \mathrm{C}\end{array}$} & \multirow{2}{*}{$\begin{array}{c}\mathrm{Ht} \\
\mathrm{J} / \mathrm{gm} \\
\text { Stm Fr }\end{array}$} & \multirow{2}{*}{$\begin{array}{c}\text { Gas/steam } \\
\mathrm{m} / 1000 \mathrm{~m} \\
p p m w\end{array}$} & \multirow{2}{*}{$\begin{array}{l}\text { Smpl H2s } \\
\text { \% air } \quad \text { ppmw }\end{array}$} & \multicolumn{9}{|c|}{ Dry Gas vol.\% } & \multirow{2}{*}{$\begin{array}{l}\text { Data Source(s) } \\
\text { Well status } \\
\text { Sampling methods } \\
\text { Comments on data }\end{array}$} \\
\hline & & & & & & & $\mathrm{CO} 2$ & $H 2 S$ & NH3 & $A r$ & $N 2$ & $\mathrm{CH} 4$ & $\mathrm{H} 2$ & $\mathrm{O} 2$ & Sum & \\
\hline \multirow[t]{4}{*}{ BLM } & & & & & $\begin{array}{c}0.010 \\
16\end{array}$ & 1.9 & 1.187 & & & 1.250 & 96.692 & & 0.871 & 0.000 & 100.0 & $\begin{array}{l}\text { Allen (1977)-Appendix; depth from Overton et al (1979), } \\
\text { Campbell et al (1981) }\end{array}$ \\
\hline & & & & & & & & & & & & & & & & $\begin{array}{l}\text { No date; hot well; Allen (1977) describes depth as less than } \\
500 \mathrm{ft} \text {; Overton et al (1979) lists same chemistry as Allen } \\
\text { (1977) and shows a map with depth } 1500 \mathrm{~m} \text { ( } 4922 \mathrm{ft}) \text {. } \\
\text { Cambell et al (1981) shows a map with well depth } 4924 \mathrm{ft} \\
\text { but no chemistry. }\end{array}$ \\
\hline & & & & & & & & & & & & & & & & air-correction by GeothermEx \\
\hline & & & & & & & & & & & & & & & & $\begin{array}{l}\text { gases converted from standard cc/L (conversion factor } \\
1 /(22.414 * 55.56) \text { ) }\end{array}$ \\
\hline \multirow[t]{4}{*}{ RRGE-1 } & & & & & $\begin{array}{c}0.027 \\
42\end{array}$ & 1.9 & 5.852 & & & 1.484 & 92.266 & & 0.306 & 0.000 & 100.0 & $\begin{array}{l}\text { Allen (1977)-Tb1 } 4 \text { and Appendix; Status Report } \\
\text { (ND)Kunze \& Tunner (1979)(completion and T data) }\end{array}$ \\
\hline & & & & & & & & & & & & & & & & $\begin{array}{l}\text { Averaged data; csd to } 3625 \mathrm{ft} \text {; completed March } 1975 \text {; } \\
296^{\circ} \mathrm{F} / 146.7^{\circ} \mathrm{C} \text { at } 4632 \mathrm{ft}\end{array}$ \\
\hline & & & & & & & & & & & & & & & & air-correction by GeothermEx \\
\hline & & & & & & & & & & & & & & & & $\begin{array}{l}\text { gases converted from standard cc/L (conversion factor } \\
1 /\left(22.414^{* 55.56)}\right.\end{array}$ \\
\hline \multirow[t]{4}{*}{ RRGE-1 } & $\begin{array}{l}\text { 03-Jun-04 } \\
\text { 13:00 }\end{array}$ & 18 & $114.4^{\circ}$ & $\begin{array}{c}578 \\
0.044\end{array}$ & -30 & & & & & & & & & & & $\begin{array}{l}\text { USGeo (2004a); Tchem 10951-7(Aug 9/04); Tchem 10960- } \\
\text { S (Aug 9/04) }\end{array}$ \\
\hline & & & & & & & & & & & & & & & & $\begin{array}{l}\text { Ref } \Gamma=\text { flowing } D H T \text { at sample time (see production test } \\
\text { data) } \\
H_{t}=f\left(\text { Ref } T-1^{\circ} \mathrm{C}\right)\end{array}$ \\
\hline & & & & & & & & & & & & & & & & $\begin{array}{l}\text { MS @, horizontal (side) port on line } 5^{\circ} 4^{\prime \prime} \text { up from FCV, } 3^{\prime} 1^{\prime \prime} \\
\text { down from WH, at } 1330 \mathrm{hrs} ; 239.6^{\circ} \mathrm{F} / 1153^{\circ} \mathrm{C} \text { in ms. }\end{array}$ \\
\hline & & & & & & & & & & & & & & & & $\begin{array}{l}\text { Condensate Ec } 450 \text { micromho, brine contamination } \\
\text { probable. Lab report: } 391 \text { gm of condensate in sample, } 0.87 \\
\text { STP ml of air, headspace at <0.50 psiaSTP }\end{array}$ \\
\hline \multirow[t]{3}{*}{ RRGE-1 } & $\begin{array}{l}\text { 04-Jun-04 } \\
13: 45\end{array}$ & 18 & $114.7^{\circ}$ & $\begin{array}{c}582 \\
0.046\end{array}$ & -29 & & & & & & & & & & & $\begin{array}{l}\text { USGeo (2004a); Tchem 10951-8(Aug 9/04); Tchem 10960- } \\
6 \text { (Aug 9/04) }\end{array}$ \\
\hline & & & & & & & & & & & & & & & & $\begin{array}{l}\text { RefT }=\text { flowing DHT at sample time (see production test } \\
\text { data) } \\
\mathrm{Ht}=\mathrm{f}\left(\mathrm{RefT}-1^{\circ} \mathrm{C}\right)\end{array}$ \\
\hline & & & & & & & & & & & & & & & & $\begin{array}{l}\text { MS @ horizontal (side) port on line } 5^{\prime} 4^{\prime \prime} \text { up from } F C V, 3^{\prime} 1^{\prime \prime} \\
\text { down from WH, at } 1350 \mathrm{hrs} ; 2384^{\circ} \mathrm{F} / 147^{\circ} \mathrm{C} \text { in ms. }\end{array}$ \\
\hline
\end{tabular}




\section{Table 4.3: Raft River - analyses of gases in steam (I)(2)}

\begin{tabular}{|c|c|c|c|c|c|c|c|c|c|c|c|c|c|c|c|c|}
\hline \multirow{2}{*}{ Name } & \multirow{2}{*}{$\begin{array}{l}\text { Date } \\
\text { Time } \\
\end{array}$} & \multirow{2}{*}{$\begin{array}{l}\text { WHP S } \\
\text { psig } \\
\end{array}$} & \multirow{2}{*}{$\begin{array}{c}\text { Smpl } \\
T^{\circ} \mathrm{C}\end{array}$} & \multirow{2}{*}{$\begin{array}{c}\mathrm{Ht} \\
\mathrm{J} / \mathrm{gm} \\
\text { Stm Fr }\end{array}$} & \multirow{2}{*}{$\begin{array}{c}\text { Gas/steam } \\
\mathrm{m} / 1000 \mathrm{~m} \\
\text { ppmw } \\
\end{array}$} & \multirow{2}{*}{$\begin{array}{l}\text { Smpl H2S } \\
\text { \% a air ppmw }\end{array}$} & \multirow[b]{2}{*}{$\mathrm{CO} 2$} & \multirow[b]{2}{*}{$\mathrm{H} 2 \mathrm{~S}$} & \multirow[b]{2}{*}{$\mathrm{NH3}$} & \multicolumn{3}{|c|}{ Dry Gas vol\% } & & & & \multirow{2}{*}{$\begin{array}{l}\text { Data Source(s) } \\
\text { Well status } \\
\text { Sampling methods } \\
\text { Comments on data }\end{array}$} \\
\hline & & & & & & & & & & $A r$ & $N 2$ & $\mathrm{CH}_{4}$ & $\mathrm{H}^{2}$ & 02 & Sum & \\
\hline & & & & & & & & & & & & & & & & $\begin{array}{l}\text { Condensate Ec } 600 \text { micromho, brine contamination } \\
\text { probable. Lab report: } 451 \text { gm of condensate in sample, } 0.94 \\
\text { STP ml of air, headspace at }<0.50 \text { psiaSTP. }\end{array}$ \\
\hline \multirow[t]{4}{*}{ RRGE-2 } & & & & & $\begin{array}{c}0.028 \\
25\end{array}$ & 6.1 & 5.095 & & & 1.708 & 89.767 & & 3.380 & 0.000 & 100.0 & $\begin{array}{l}\text { Allen (1977)-Tbl } 4 \text { and Appendix; Status Report (ND); } \\
\text { Kunze and Turner (1979)(completion \& T data) }\end{array}$ \\
\hline & & & & & & & & & & & & & & & & 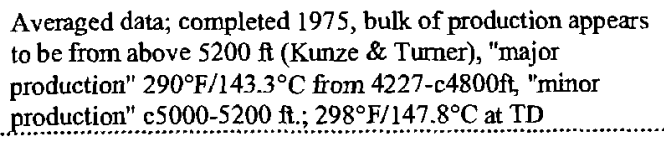 \\
\hline & & & & & & & & & & & & & & & & air-correction by GeothermEx \\
\hline & & & & & & & & & & & & & & & & $\begin{array}{l}\text { gases converted from standard cc/L (conversion factor } \\
1 /\left(22.414^{*} 55.56\right) \text { ); apparent error in tabulation - reported } \\
\text { total NCGmkm is }>>\text { sum of components }\end{array}$ \\
\hline \multirow[t]{4}{*}{ RRGE-2dpm } & $\begin{array}{l}\text { 27-May-04 } \\
15: 45\end{array}$ & 13 & $114.2^{\circ}$ & $\begin{array}{c}584 \\
0.047\end{array}$ & -30 & & & & & & & & & & & $\begin{array}{l}\text { USGeo (2004a); Tchem 1095!-5(Aug 9/04); Tchem } \\
10960-3 \text { (Aug } 9 / 04 \text { ) }\end{array}$ \\
\hline & & & & & & & & & & & & & & & & $\begin{array}{l}\text { WHP surging } 11-15 \text { (0-60ga) } \\
\text { RefT = flowing DHT at sample time (see production test } \\
\text { data) } \\
\left.\text { Ht }=\text { f(RefT }-1^{\circ} \mathrm{C}\right)\end{array}$ \\
\hline & & & & & & & & & & & & & & & & $\begin{array}{l}\text { MS @ horizontal (side) port on line } 5^{\prime} 4^{\prime \prime} \text { up from } F C V, 3^{\prime} l^{\prime \prime} \\
\text { down from WH, at } 1600 \mathrm{hrs} ; 2384^{\circ} / 117^{\circ} \mathrm{C} \text { in ms. }\end{array}$ \\
\hline & & & & & & & & & & & & & & & & $\begin{array}{l}\text { Condensate Ec } 450 \text { micromho, brine contamination } \\
\text { probable. Lab reportt } 418 \mathrm{gm} \text { of condensate in sample, } 0.53 \\
\mathrm{STP} \text { ml of air, headpace at }<0.50 \text { psiasTP. }\end{array}$ \\
\hline \multirow[t]{4}{*}{ RRGE-2dpn } & $\begin{array}{l}\text { 28-May-04 } \\
\text { 16:15 }\end{array}$ & 11 & $113.7^{\circ}$ & $\begin{array}{c}583 \\
0.048\end{array}$ & -30 & & & & & & & & & & & $\begin{array}{l}\text { USGeo (2004); Tchem 10951-6(Aug 9/04); Tchem } 10960 \\
4 \text { (Aug 9/04) }\end{array}$ \\
\hline & & & & & & & & & & & & & & & & $\begin{array}{l}\text { "Some very high pressure surges up to } 18 \mathrm{psi} \text { (GEx: at WH } \\
\text { or ms?). Flow dropping } 1 / 4 \text { " every couple of hours." } \\
\text { RefT }=\text { flowing DHT at sample time (see production test } \\
\text { data) } \\
\mathrm{Ht}=\mathrm{f}\left(\mathrm{RefT}-1^{\circ} \mathrm{C}\right)\end{array}$ \\
\hline & & & & & & & & & & & & & & & & $\begin{array}{l}\text { MS @ horizontal (side) port on line } 5^{\prime} 4^{\prime \prime} \text { up from FCV, } 3^{\prime} l^{1} \\
\text { down from WH, at } 1630 \mathrm{hs} ; 2366^{\circ} / 1137^{\circ} \mathrm{C} \text { in } \mathrm{ms}\end{array}$ \\
\hline & & & & & & & & & & & & & & & & $\begin{array}{l}\text { Condensate Ec } 300 \text { micromho, brine contamination } \\
\text { probable. Lab report: } 375 \text { gm of condensate in sample, } 0.47\end{array}$ \\
\hline
\end{tabular}


Table 4.3: Raft River - analyses of gases in steam (1)(2)

\begin{tabular}{|c|c|c|c|c|c|c|c|c|c|c|c|c|c|c|c|c|c|}
\hline \multirow{2}{*}{ Name } & \multirow{2}{*}{$\begin{array}{l}\text { Date } \\
\text { Time }\end{array}$} & \multirow{2}{*}{$\begin{array}{l}\text { WHT } \\
\text { psig }\end{array}$} & \multirow{2}{*}{$\begin{array}{l}\text { Smpl } \\
T^{\circ} \mathrm{C}\end{array}$} & \multirow{2}{*}{$\begin{array}{c}\mathbf{H t} \\
\mathbf{J} / \mathrm{gm} \\
\text { Stm Fr }\end{array}$} & \multirow{2}{*}{\begin{tabular}{c} 
Gassteam \\
\hdashline $\mathbf{m} / 1000 \mathrm{~m}$ \\
$p_{p m w}$
\end{tabular}} & \multirow{2}{*}{$\begin{array}{l}\text { Smpl } \\
\text { Smair }\end{array}$} & \multirow{2}{*}{$\begin{array}{c}H 2 S \\
p p m w\end{array}$} & \multicolumn{9}{|c|}{ Dry Gas vol\% } & \multirow{2}{*}{$\begin{array}{l}\text { Data Source(s) } \\
\text { Well status } \\
\text { Sampling methods } \\
\text { Comments on data }\end{array}$} \\
\hline & & & & & & & & $\mathrm{CO} 2$ & $\mathrm{H} 2 \mathrm{~S}$ & $N H 3$ & $A r$ & $N 2$ & $\mathrm{CH} 4$ & $\mathrm{H} 2$ & 02 & Sum & \\
\hline & & & & & & & & & & & & & & & & & STP ml of air headspace at $<0.50$ psiasTP \\
\hline \multirow[t]{4}{*}{ RRGE-3rW } & $\begin{array}{l}\text { 18-May-04 } \\
\text { 19:00 }\end{array}$ & 20 & $118.5^{\circ}$ & $\begin{array}{c}603 \\
0.048\end{array}$ & $\begin{array}{c}0.298 \\
590\end{array}$ & 2.7 & 4.13 & 47.800 & 0.733 & -1.600 & 1.090 & 50.800 & 0.229 & 0.870 & 0.000 & 101.5 & $\begin{array}{l}\text { USGeo (2004); Tchem 10951-2(Aug 9/04); Tchem 10960- } \\
1 \text { (Aug 9/04) }\end{array}$ \\
\hline & & & & & & & & & & & & & & & & & $\begin{array}{l}\text { WHP surging } 16-24 \mathrm{psig}(0-60 \text { gauge); WHPg is best } \\
\text { estimate of average. } \\
\text { RefT = flowing DHT at sample time (see production test } \\
\text { data) } \\
\mathrm{Ht}=\mathrm{f}\left(\mathrm{RefT}-1^{\circ} \mathrm{C}\right)\end{array}$ \\
\hline & & & & & & & & & & & & & & & & & $\begin{array}{l}\text { Steam sample from ms on vertical (top) port }-1.5 \mathrm{~m} \text { upstr of } \\
\mathrm{FCV},-4 \mathrm{~m} \text { from WH@1930hrs; } 244.7^{\circ} \mathrm{F} / 118.2^{\circ} \mathrm{C}\end{array}$ \\
\hline & & & & & & & & & & & & & & & & & $\begin{array}{l}\text { Could not avoid surges of brine into steam (condensate } \mathrm{Ec} \\
>600 \text { micromho). Brine contamination probable. Lab } \\
\text { reports } 384 \text { gm condensate in sample, headspace at } 6.53 \\
\text { psisasTP }\end{array}$ \\
\hline \multirow[t]{4}{*}{ RRGE-3Tw } & $\begin{array}{l}\text { 19-May-04 } \\
11: 00\end{array}$ & 12 & $114.1^{\circ}$ & $\begin{array}{c}601 \\
0.055\end{array}$ & $\begin{array}{c}0.376 \\
751\end{array}$ & 20.5 & 4.43 & 51.500 & 0.623 & 1.380 & 1.020 & 44.300 & 0.221 & 0.940 & 0.000 & 100.0 & $\begin{array}{l}\text { USGeo (2004a); Tchem 10951-1(Aug 9/04); Tchem 10952- } \\
1 \text { (Aug 9/04) }\end{array}$ \\
\hline & & & & & & & & & & & & & & & & & $\begin{array}{l}\text { WHP surging } 9-12 \text { psig at start of sample collection and } 8 \text { - } \\
15 \text { psig at end }(0-60 \text { gauge); WHPg is best estimate of } \\
\text { average. } \\
\text { "Temperature difference in ms at top and side ports }\left(5^{\circ} \mathrm{F}\right) \text { is } \\
\text { not explained (ports/valves/ms inlet well-insulated)." Smplt } \\
\text { is average at the two port locations. } \\
\text { RefT }=\text { flowing DHT at sample time (see production test } \\
\text { data) } \\
\text { Ht }=f\left(R e f T-1^{\circ} \mathrm{C}\right)\end{array}$ \\
\hline & & & & & & & & & & & & & & & & & $\begin{array}{l}\text { Steam sample from ms on vertical (top) port }-1.5 \mathrm{~m} \text { upstr of } \\
\text { FCV }-4 \mathrm{~m} \text { from WH @1040hrs; } 240^{\circ} \mathrm{F} / 1155^{\circ} \mathrm{C}\end{array}$ \\
\hline & & & & & & & & & & & & & & & & & $\begin{array}{l}\text { Condensate Ec } 30 \text { micromho (no brine contamination } \\
\text { indicated) } \\
\text { "Sample is more yellow then yesterday. Closed flask when } \\
\text { no longer being sucked in. About } 60 \text { to } 70 \% \text { full with } \\
\text { liquid." } \\
\text { Lab reports } 337 \text { gm condensate in sample, headspace at }\end{array}$ \\
\hline RRGP-4rw & $\begin{array}{l}\text { 18-Jun- } 04 \\
14: 40\end{array}$ & 4 & $103.6^{\circ}$ & $\begin{array}{c}588 \\
0.069\end{array}$ & -107 & & & & & & & & & & & & $\begin{array}{l}\text { USGeo (2004a); Tchem 10951-9(Aug 9/04); Tchem } 10960 \text {. } \\
\text { 7(Aug 9/04) }\end{array}$ \\
\hline
\end{tabular}




\section{Table 4.3: Raft River - analyses of gases in steam ${ }^{(1)(2)}$}

\begin{tabular}{|c|c|c|c|c|c|c|c|c|c|c|c|c|c|c|c|c|}
\hline \multirow{2}{*}{ Name } & \multirow{2}{*}{$\begin{array}{l}\text { Date } \\
\text { Time }\end{array}$} & \multirow{2}{*}{$\begin{array}{c}\text { WHP } \\
\text { psig } \\
\end{array}$} & \multirow{2}{*}{$\begin{array}{l}\text { Simpl } \\
T^{\circ} \mathrm{C}\end{array}$} & \multirow{2}{*}{$\begin{array}{c}\mathrm{Ht} \\
\mathrm{J} / \mathrm{gm} \\
\text { Stm } \mathrm{Fr}\end{array}$} & \multirow{2}{*}{$\begin{array}{c}\text { Gadsteam } \\
\mathrm{m} / 1000 \mathrm{~m} \\
\mathrm{ppmw}\end{array}$} & \multirow{2}{*}{ Smpl } & \multirow[b]{2}{*}{$\mathrm{CO} 2$} & \multirow[b]{2}{*}{$\mathrm{H} 2 \mathrm{~S}$} & \multicolumn{4}{|c|}{ Dry Gas vol\% } & & & & \multirow{2}{*}{$\begin{array}{l}\text { Data Source(s) } \\
\text { Well status } \\
\text { Sampling methods } \\
\text { Comments on data }\end{array}$} \\
\hline & & & & & & & & & NH3 & $A r$ & $\mathrm{N2}$ & $\mathrm{CH} 4$ & $\mathrm{H} 2$ & 02 & Sum & \\
\hline & & & & & & & & & & & & & & & & $\begin{array}{l}\text { This well had to be restricted down to } 5 \text { five turns on FCV } \\
\text { to get a constant flow for sampling. } \\
\text { Only able to sample once on this well because of geyser } \\
\text { effect. } \\
\text { Lab report lists water sample date } 20 \text { June but R.Nye field } \\
\text { report lists } 18 \text { June. } \\
\text { RefT }=\text { flowing DHT at sample time (see production test } \\
\text { data) } \\
\mathrm{Ht}=\mathrm{f}\left(\mathrm{RefT}-1^{\circ} \mathrm{C}\right)\end{array}$ \\
\hline & & & & & & & & & & & & & & & & $\begin{array}{l}\text { Ms @ middle port on line } 3^{\prime} 2^{\prime} \text { from } \mathrm{FCV}, 9^{\prime} 10^{\prime} \text { from well } \\
\text { head, at } 1443 \mathrm{hrs} ; 218.3^{\circ} \mathrm{F} / 103.5^{\circ} \mathrm{C} \text { in ms. Very little } \\
\text { pressure and flow through ms and cooling coil; was only } \\
\text { able to fill bottle } 1 / 2 \text { full. }\end{array}$ \\
\hline & & & & & & & & & & & & & & & & $\begin{array}{l}\text { Condensate Ec } 400 \text { micromho, brine contamination } \\
\text { probable. Lab report: } 225 \text { gm of condensate in sample, } \\
482.10 \text { STP ml of air, headspace at }<0.50 \text { psiaSTP. }\end{array}$ \\
\hline \multirow[t]{4}{*}{ RRGP-5rw } & \multirow[t]{4}{*}{$\begin{array}{l}\text { 21-May-04 } \\
12: 30\end{array}$} & \multirow[t]{4}{*}{8} & \multirow[t]{4}{*}{$105.6^{\circ}$} & \multirow[t]{4}{*}{$\begin{array}{c}544 \\
0.045\end{array}$} & \multirow[t]{4}{*}{-30} & & & & & & & & & & & $\begin{array}{l}\text { USGeo (2004a); Tchem 10951-3(Aug 9/04); Tchem 10960- } \\
2 \text { (Aug 9/04) }\end{array}$ \\
\hline & & & & & & & & & & & & & & & & $\begin{array}{l}\text { WHP surging 6.5-8.5 (0-60ga) } \\
\text { RefT = flowing DHT at sample time (see production test } \\
\text { data) } \\
\mathrm{Ht}=\mathrm{f}\left(\mathrm{RefT}-1^{\circ} \mathrm{C}\right)\end{array}$ \\
\hline & & & & & & & & & & & & & & & & $\begin{array}{l}\text { MS @ horizontal (side) port on line } 5^{\prime} 4^{\prime \prime} \text { up from FCV, } 3^{\prime} 1^{\prime \prime} \\
\text { down from WH, at } 1245 \mathrm{hrs} ; 222.3^{\circ} \mathrm{F} / 105.7^{\circ} \mathrm{C} \text { in ms. }\end{array}$ \\
\hline & & & & & & & & & & & & & & & & $\begin{array}{l}\text { Condensate Ec } 200 \text { micromho, brine contamination } \\
\text { probable. Lab report: } 421 \text { gm of condensate and } 0.65 \text { STP } \\
\text { ml of air in sample, headspace at }<0.50 \text { psiaSTP. }\end{array}$ \\
\hline \multirow[t]{4}{*}{ RRGP-Srw } & \multirow[t]{4}{*}{$\begin{array}{l}\text { 22-May-04 } \\
16: 30\end{array}$} & \multirow[t]{4}{*}{9} & \multirow[t]{4}{*}{$105.0^{\circ}$} & \multirow[t]{4}{*}{$\begin{array}{c}547 \\
0.048\end{array}$} & \multirow[t]{4}{*}{-30} & & & & & & & & & & & $\begin{array}{l}\text { USGeo (2004a); Tchem 10951-4(Aug 9/04); Tchem } \\
\text { 10952-2(Aug 9/04) }\end{array}$ \\
\hline & & & & & & & & & & & & & & & & $\begin{array}{l}\text { WHP surging } 8-10(0-60 \mathrm{ga}) \\
\text { RefT }=\text { flowing DHT at sample time (see production test } \\
\text { data) } \\
\mathrm{Ht}=\mathrm{f}\left(\mathrm{RefT}-1^{\circ} \mathrm{C}\right)\end{array}$ \\
\hline & & & & & & & & & & & & & & & & $\begin{array}{l}\text { MS @ horizontal (side) port on line } 5^{\prime} 4^{\prime \prime} \text { up from FCV, 3' 1" } \\
\text { down from WH, at } 1710 \mathrm{hrs} ; 221.2^{\circ} \mathrm{F} / 105.1^{\circ} \mathrm{C} \text { in ms. }\end{array}$ \\
\hline & & & & & & & & & & & & & & & & Condensate Ec 400 micromho, brine contamination \\
\hline
\end{tabular}




\section{Table 4.3: Raft River - analyses of gases in steam (I)(2)}

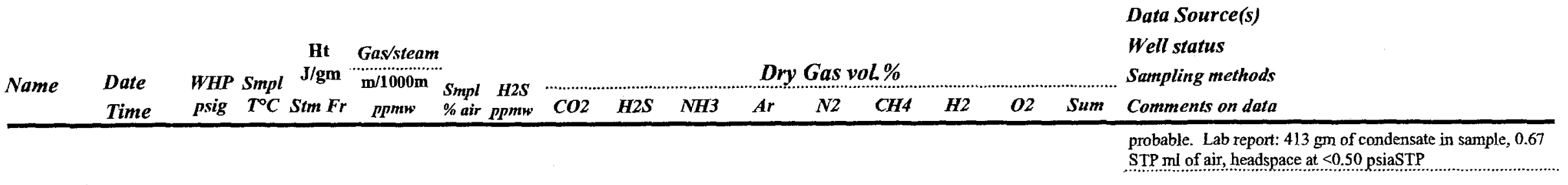

(1) After calculated removal of air contamination on the basis of measured oxygen concentration

(2) Negative numbers indicate values less than (e.g. -30 indicates $<30$ ) 
TELEPHONE: (510) 527-9876

FAX: (510) 527-8164

E-MAIL: mw@geothermex.com

\section{FIGURES}




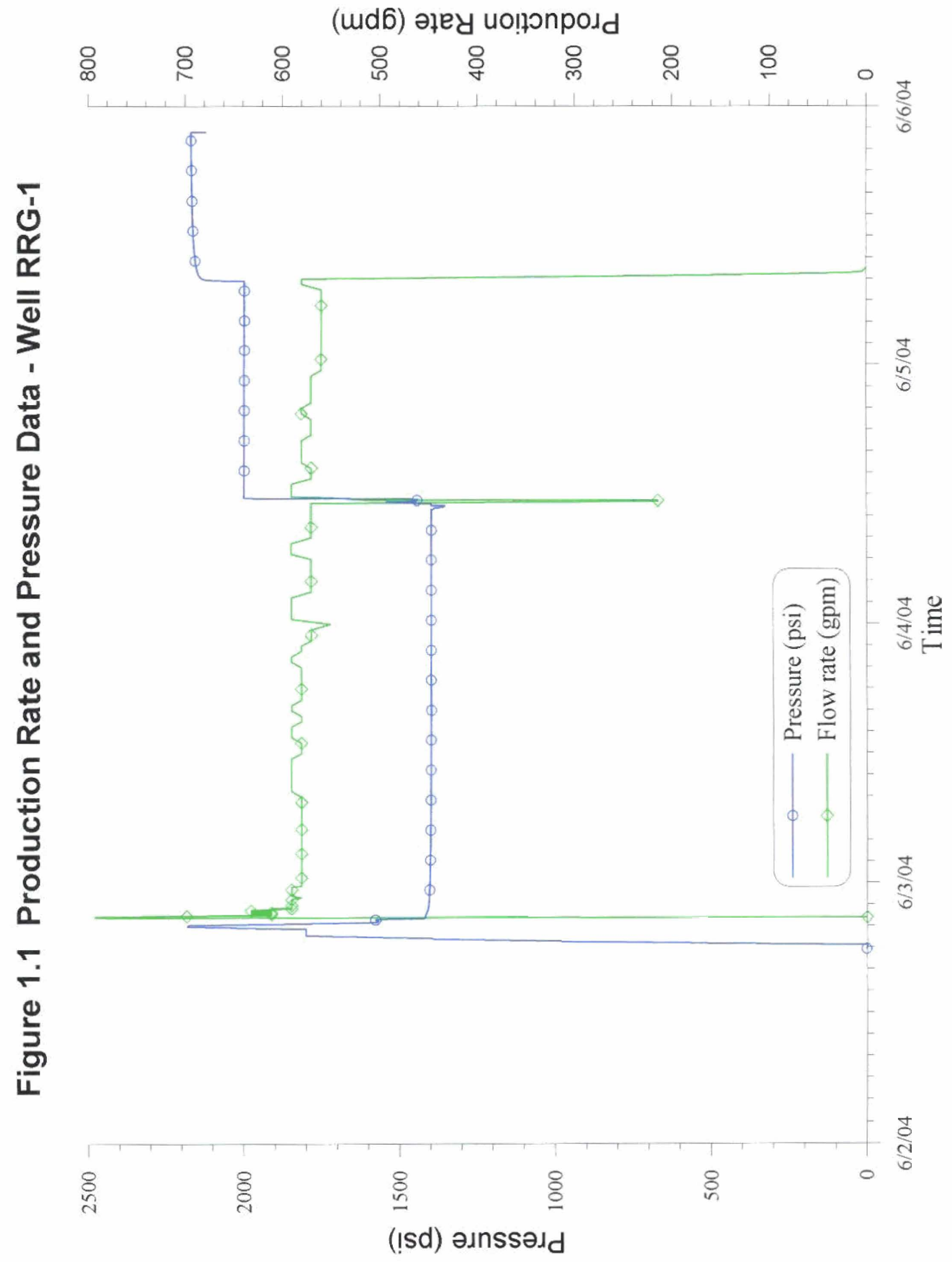




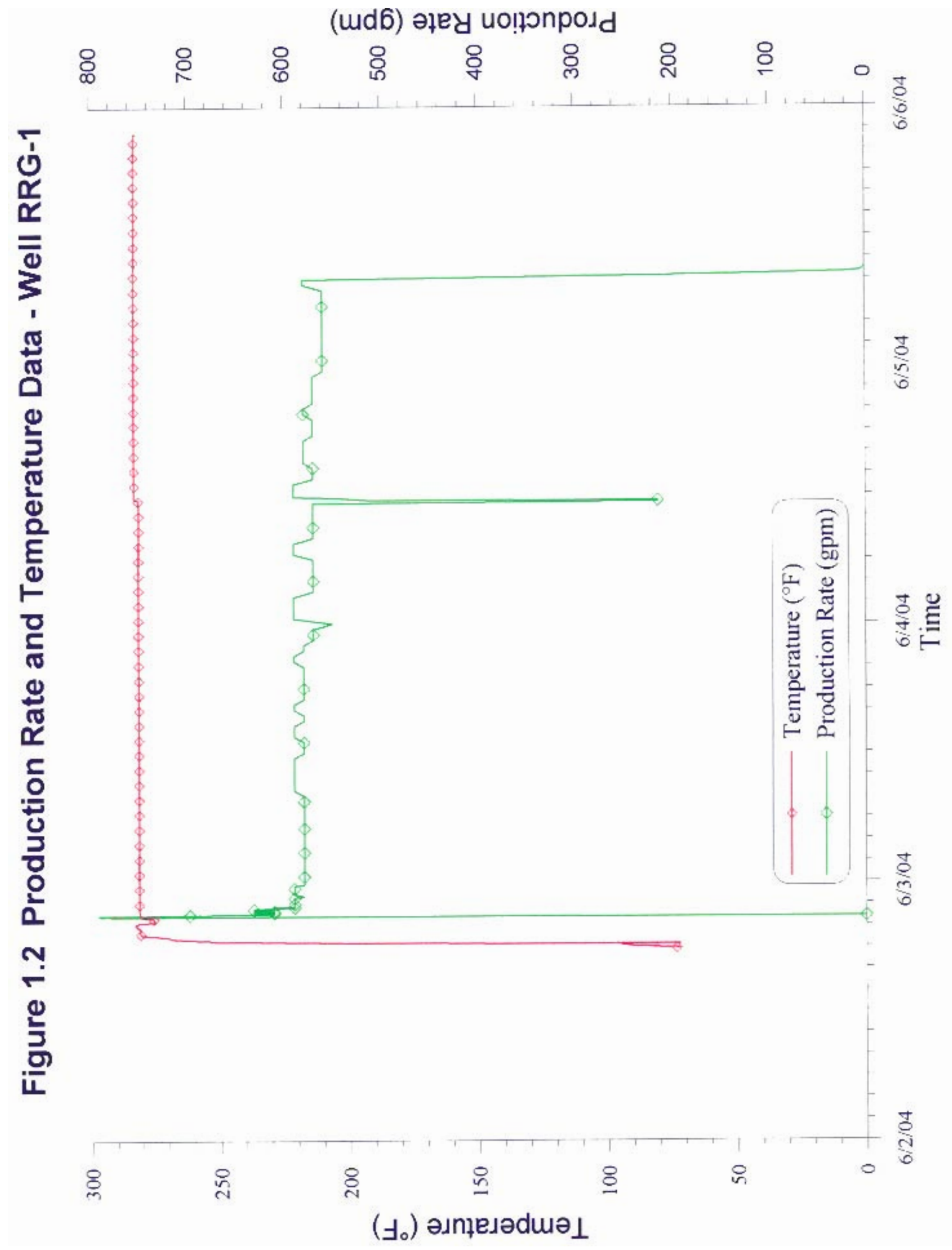




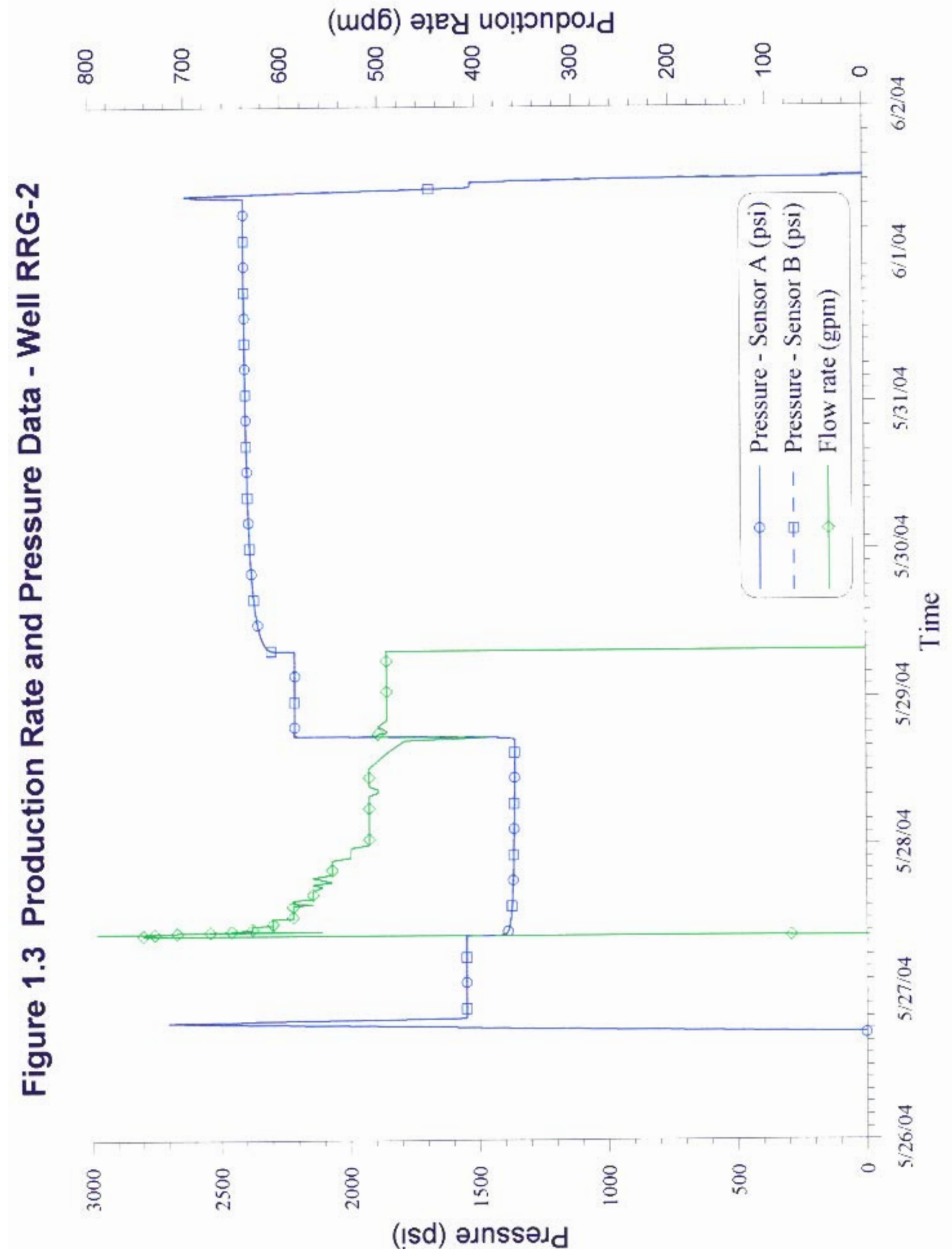




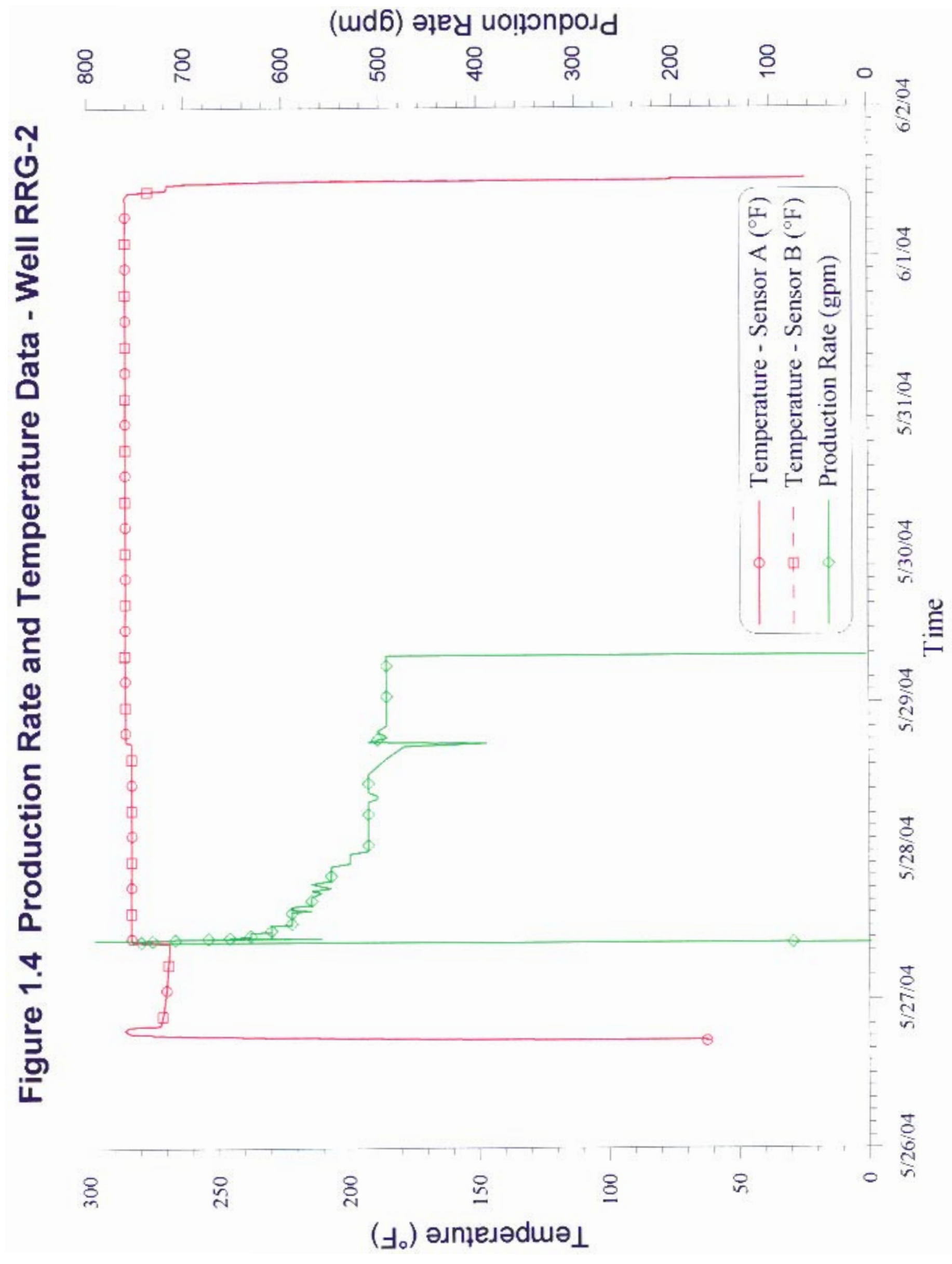


(mad6) əłey uo!̣onpodd

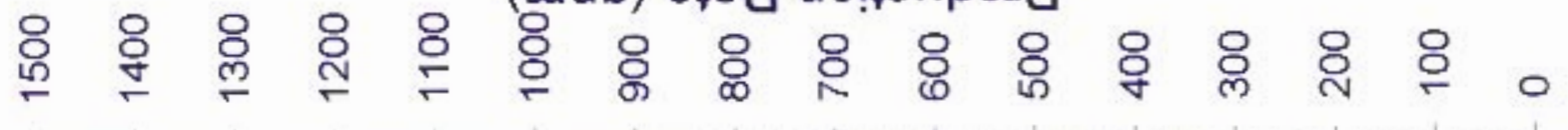

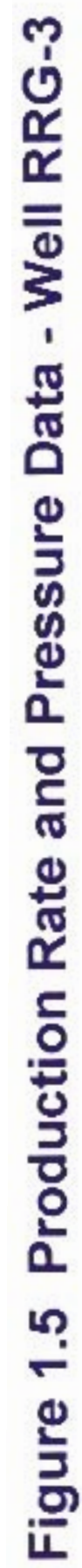

(大)

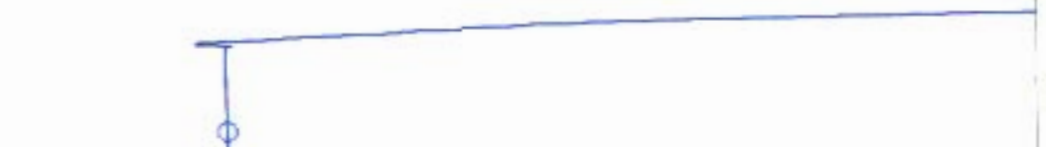

है

$<m$

官

ڤ

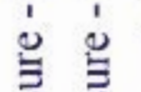

苟产芳

造运这
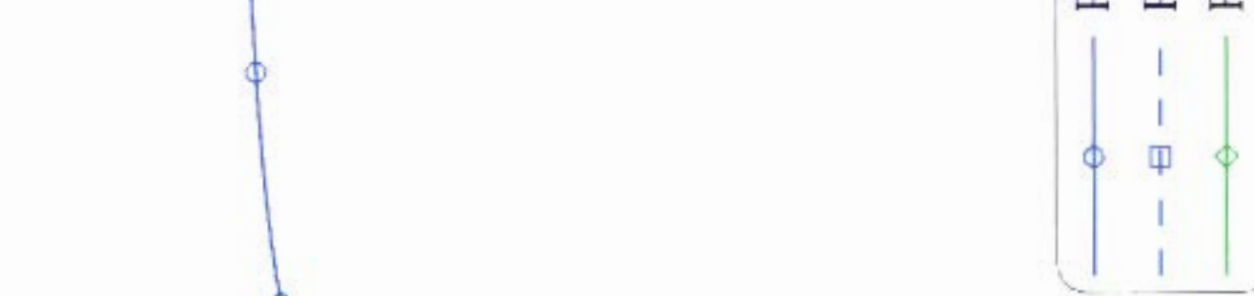

$\frac{2}{2}$

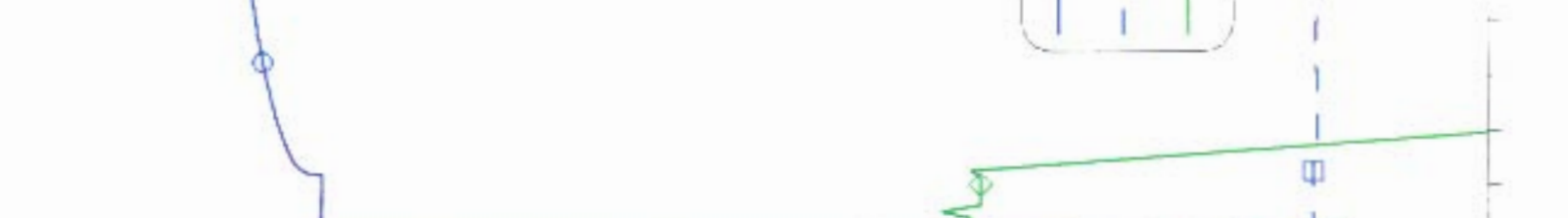

รั

总

‡

邑

8

号

$\frac{\vec{D}}{\frac{D}{2}}$

(!sd) əגnssəגd 
(md6) әңеy uo!̣onpodd

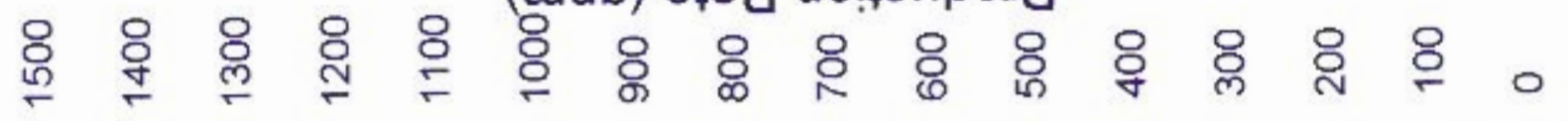

$n$
0
0
$=$

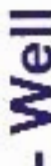

(1)

ธ

(1)

른

T)

(1)

틀

을

तิ

\%

$\frac{5}{3}$

$\stackrel{\circ}{-}$

d

כ

은
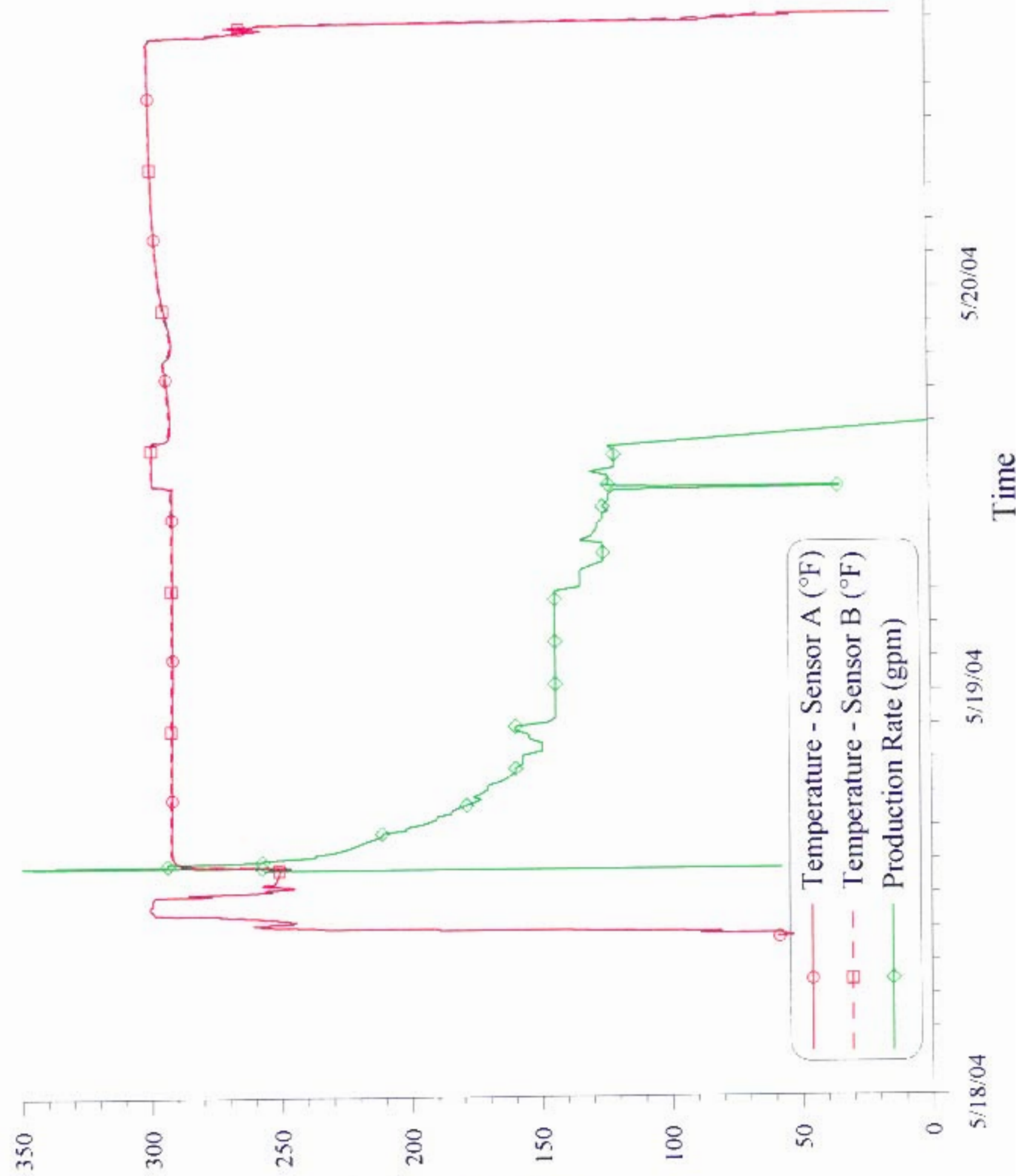

$\left(\exists_{0}\right)$ əגกฺฺ 


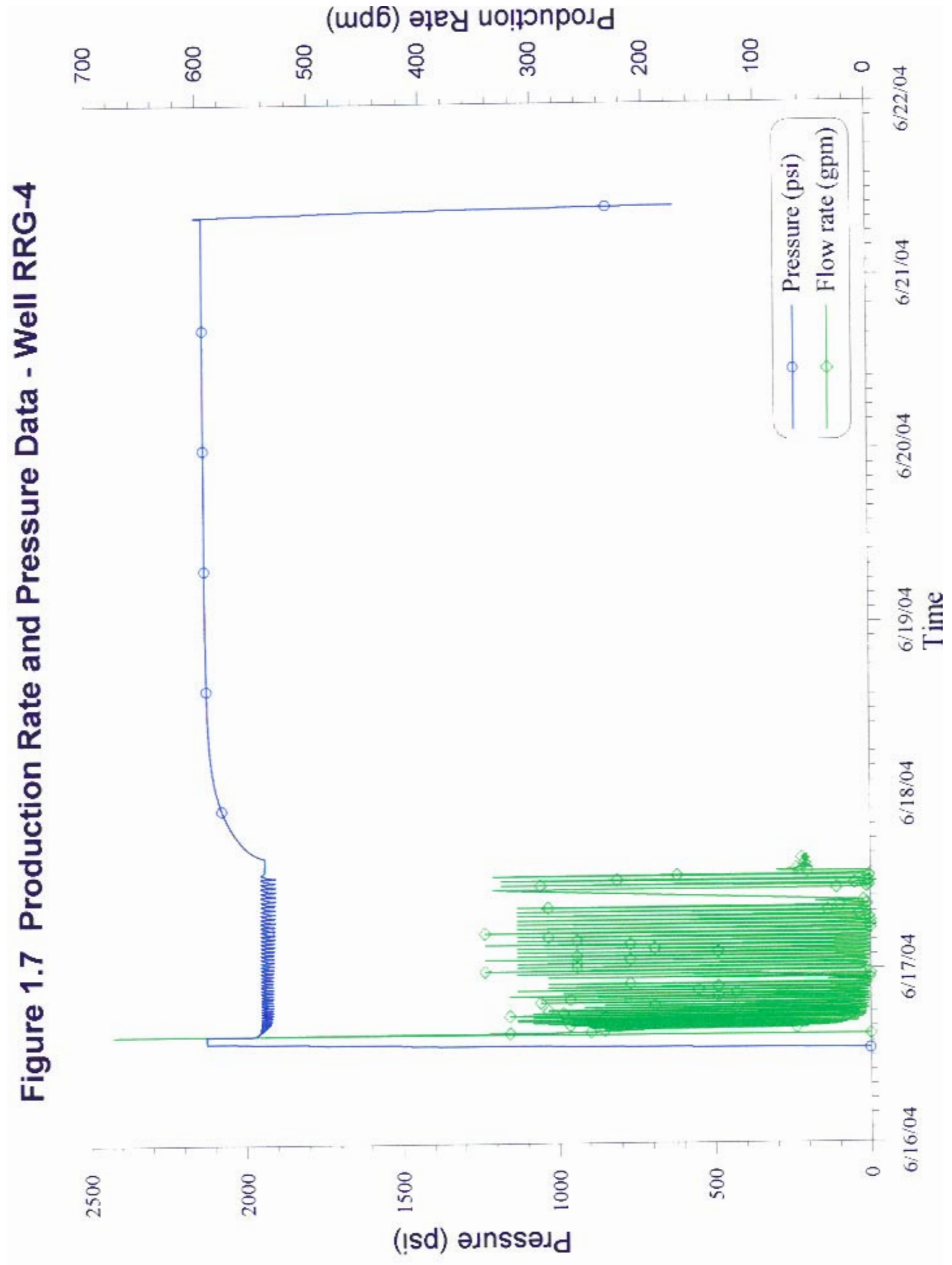




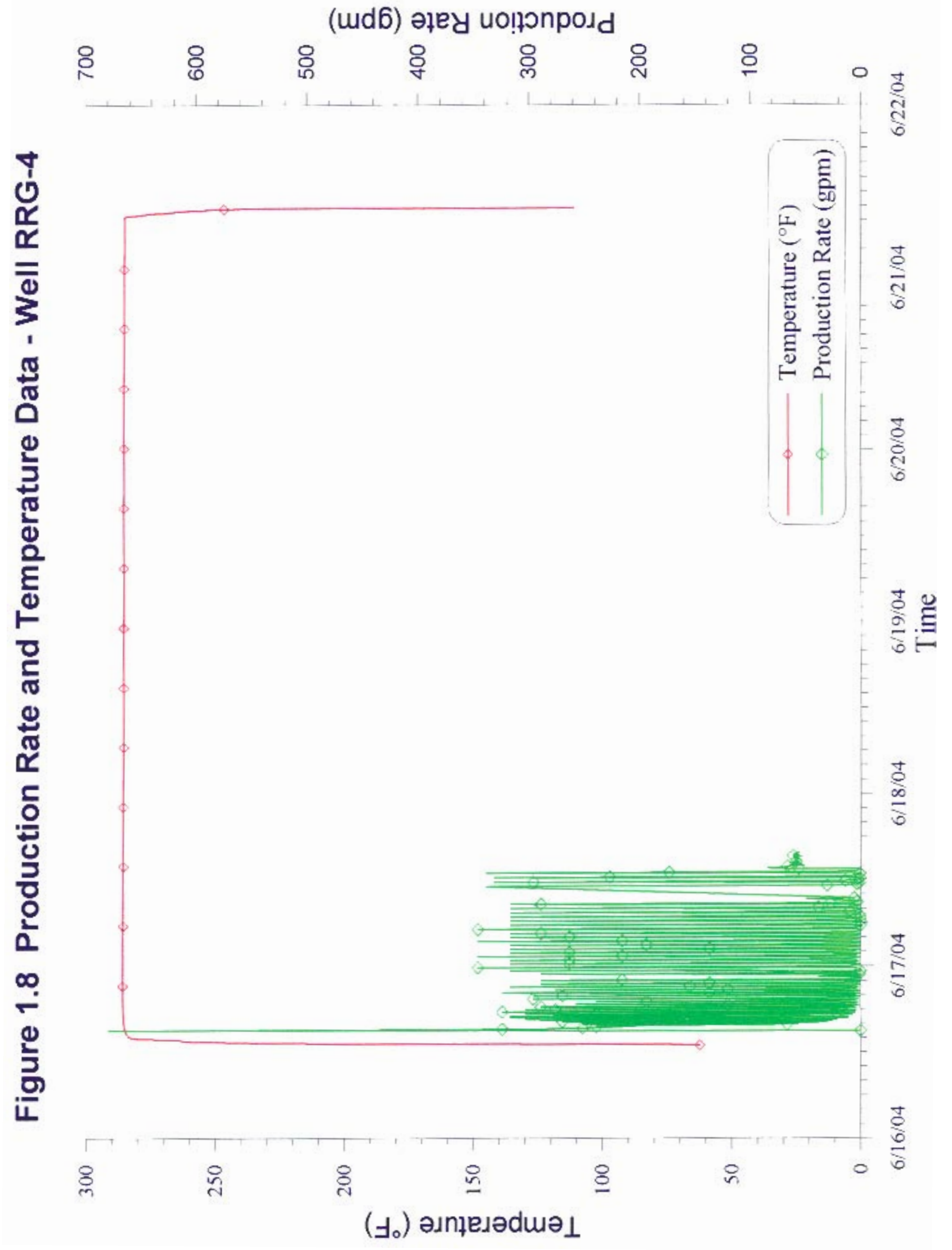




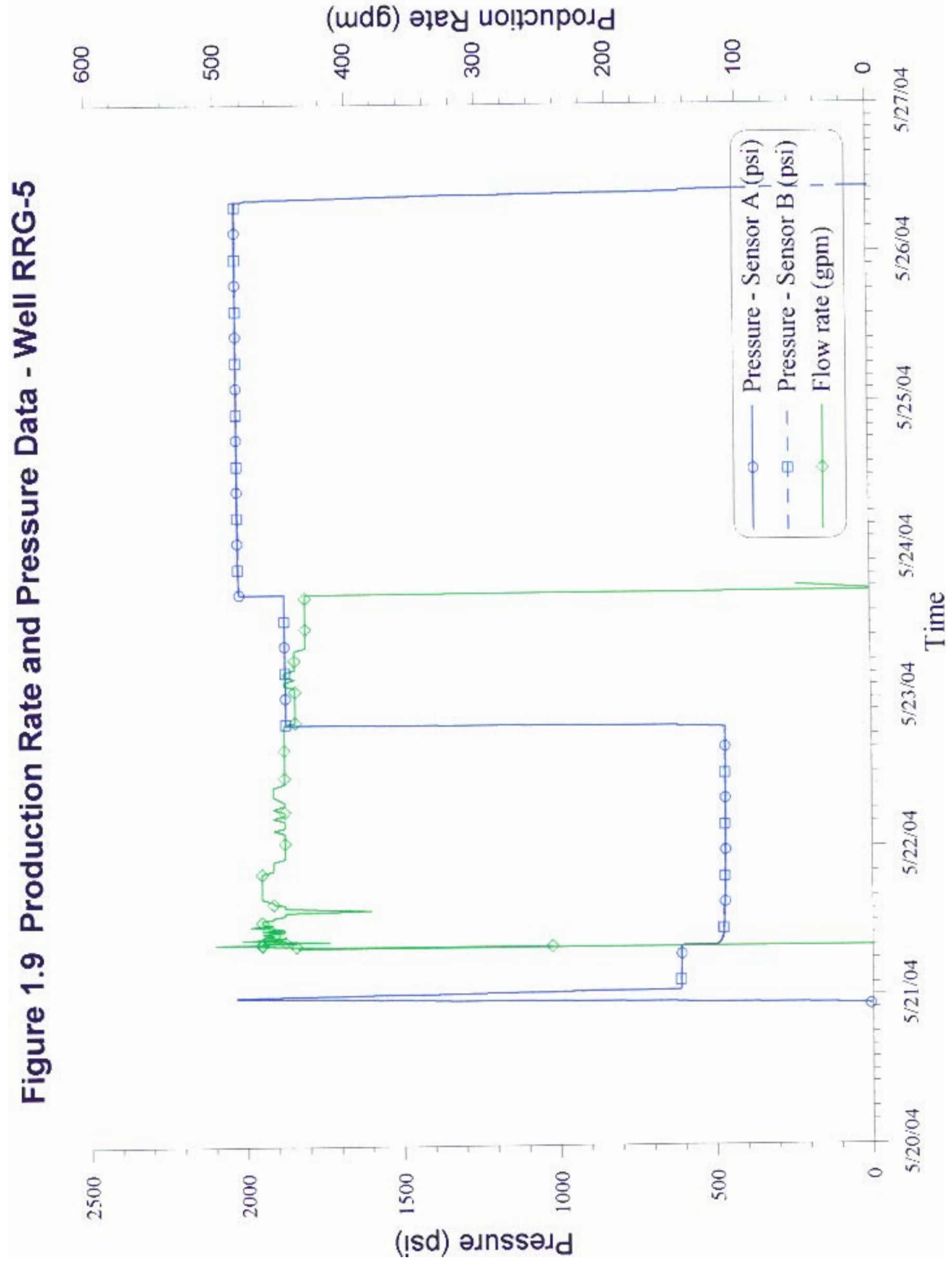




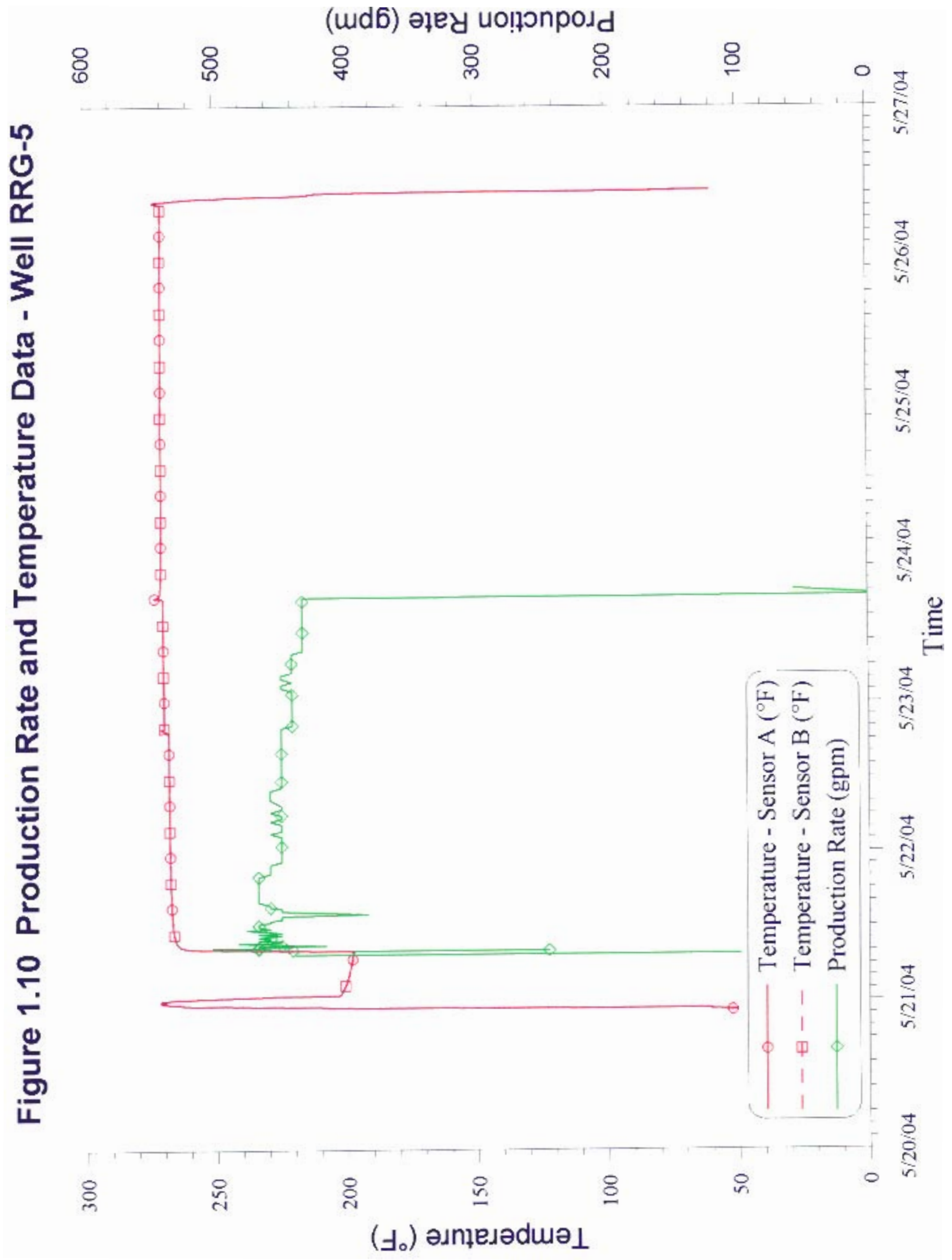


Figure 1.11: Downhole Summary Plot - Raft River Well RRG-1

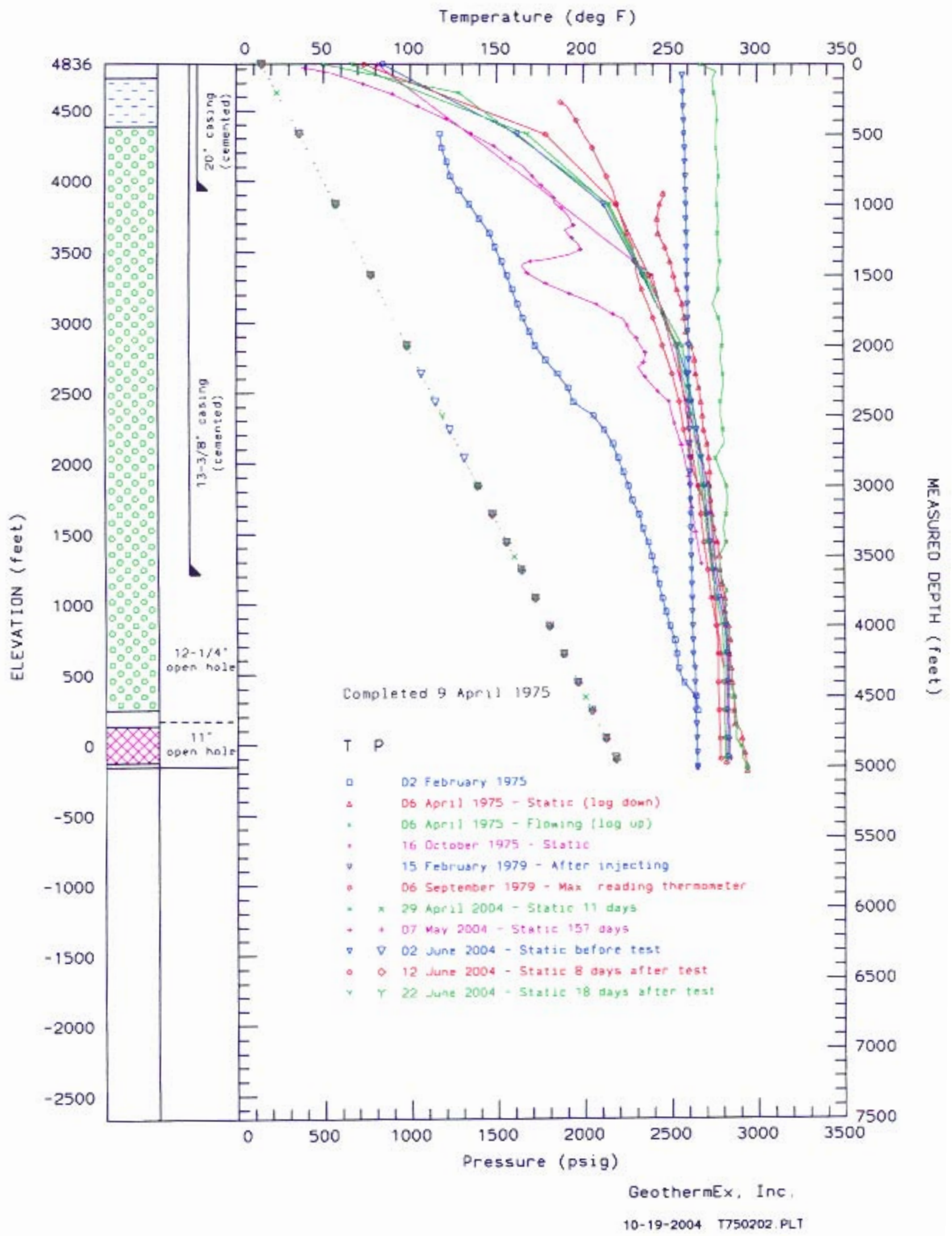


Figure 1.11A: Explanation for Downhole Summary Plots

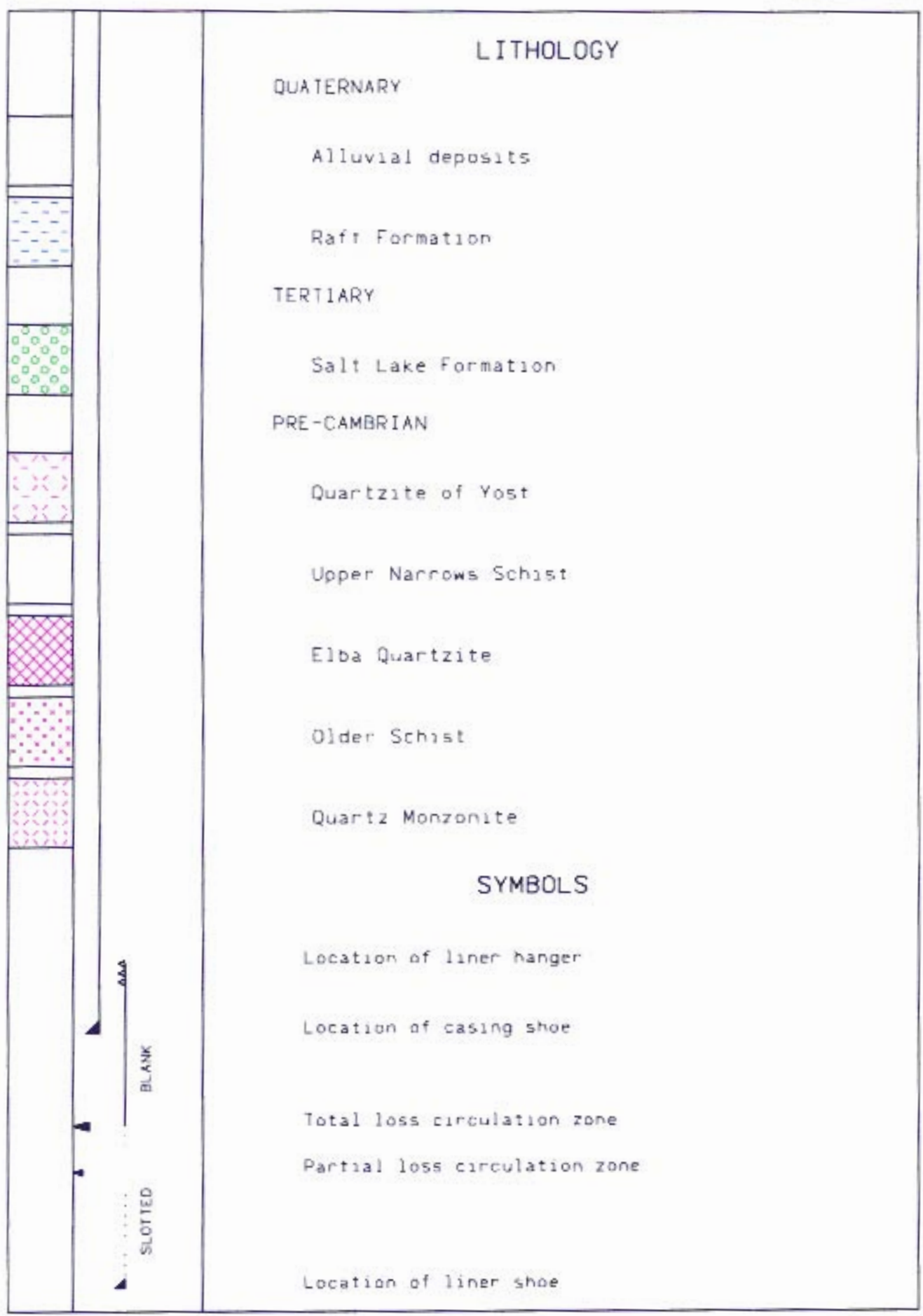

GeothermEx, Inc.

10-19-2004 F: DUNAY P.T 
Figure 1.12: Downhole Summary Plot - Raft River Well RRG-2

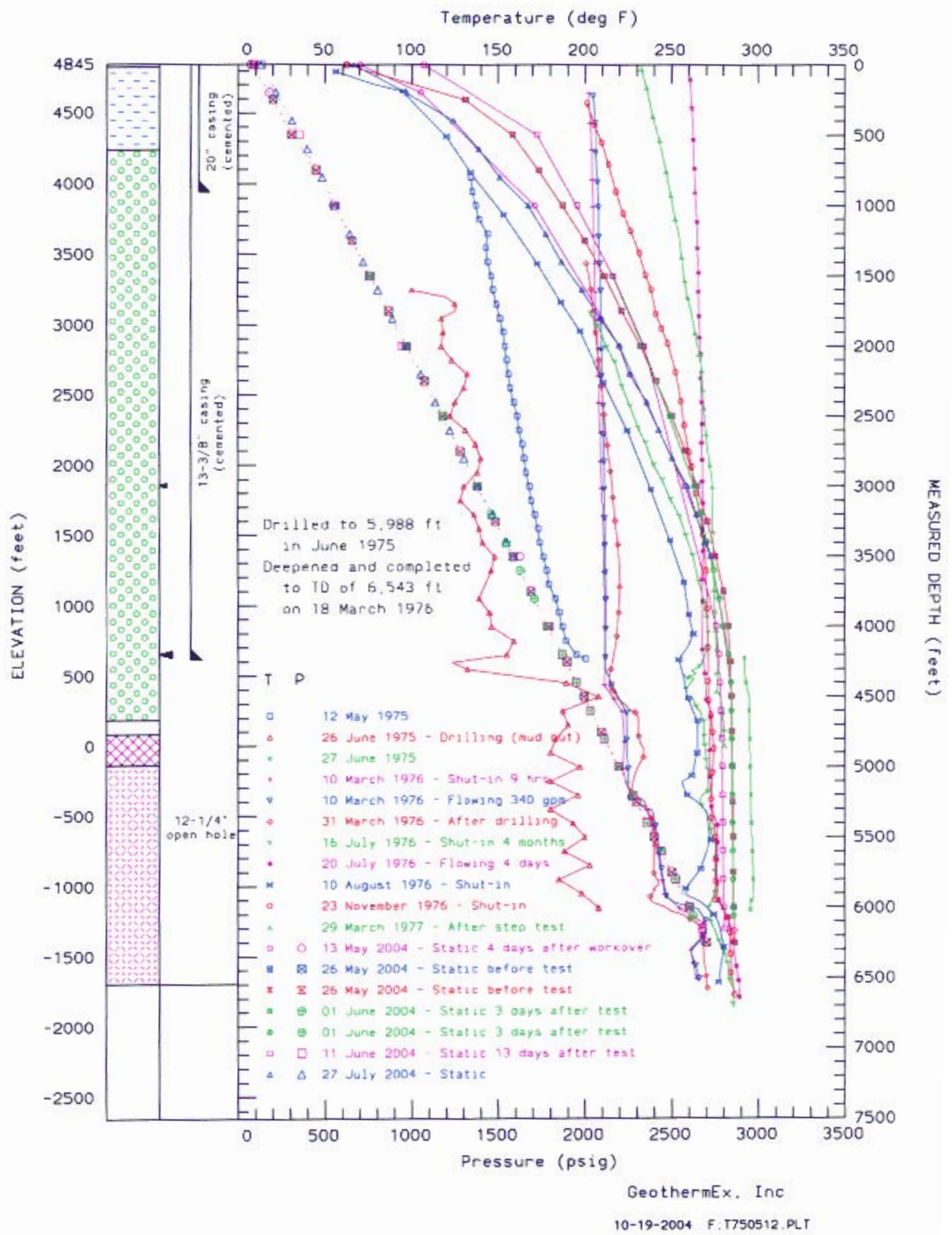


Figure 1.13. Downhole Summary Plot - Raft River Well RRG-3

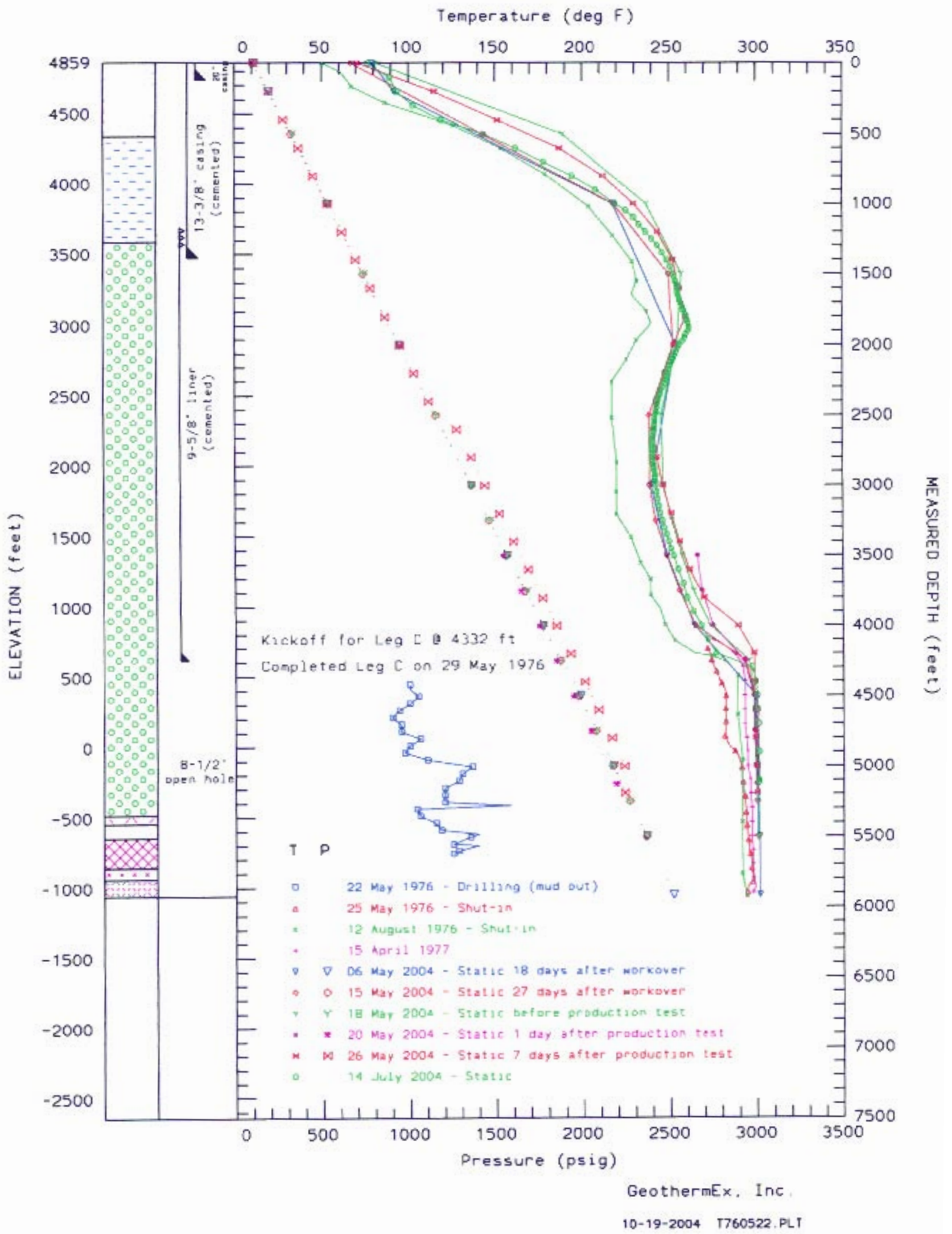


Figure 1 14. Downhole Summary Plot - Raft River Well RRG-4

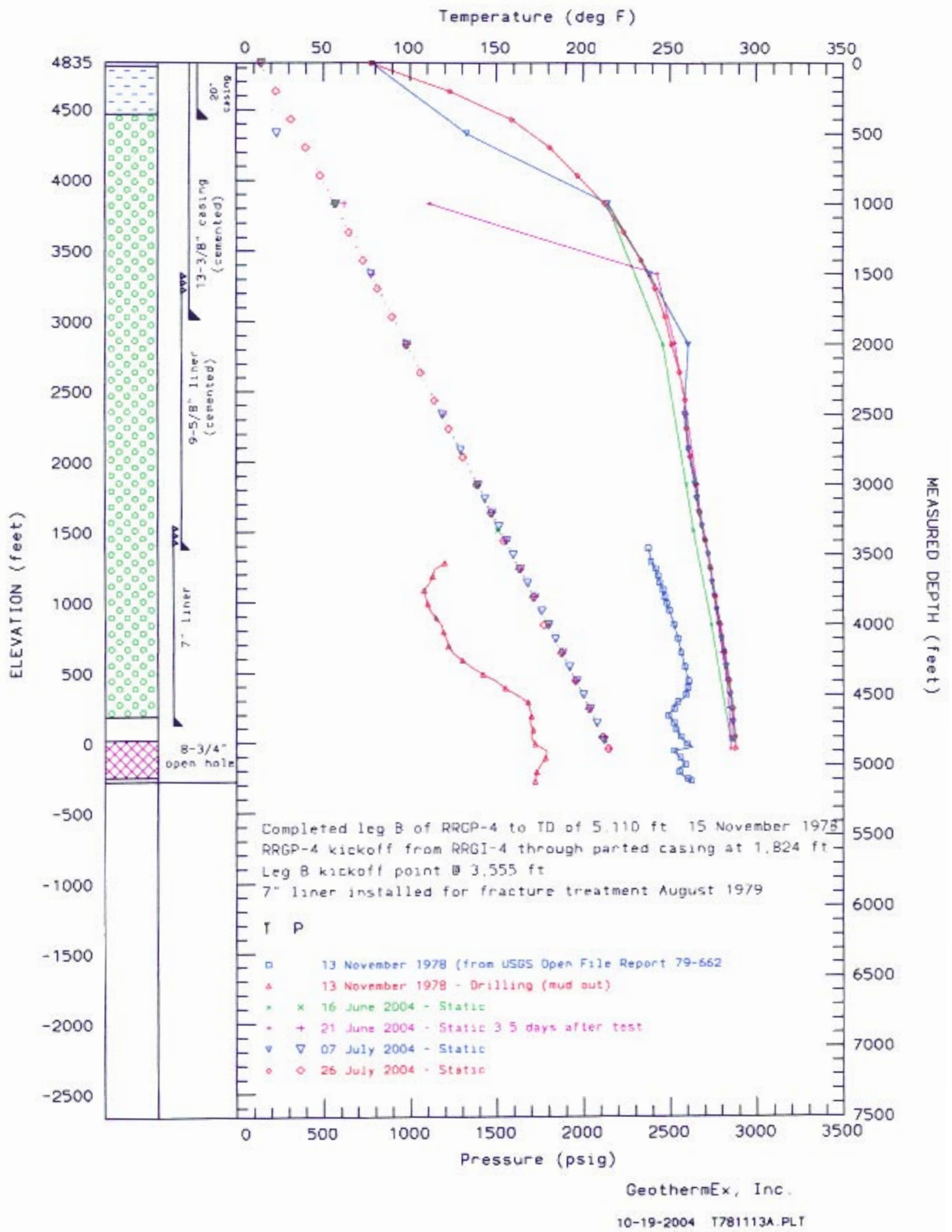


Figure 1.15: Downhole Summary Plot - Raft River Well RRG-5

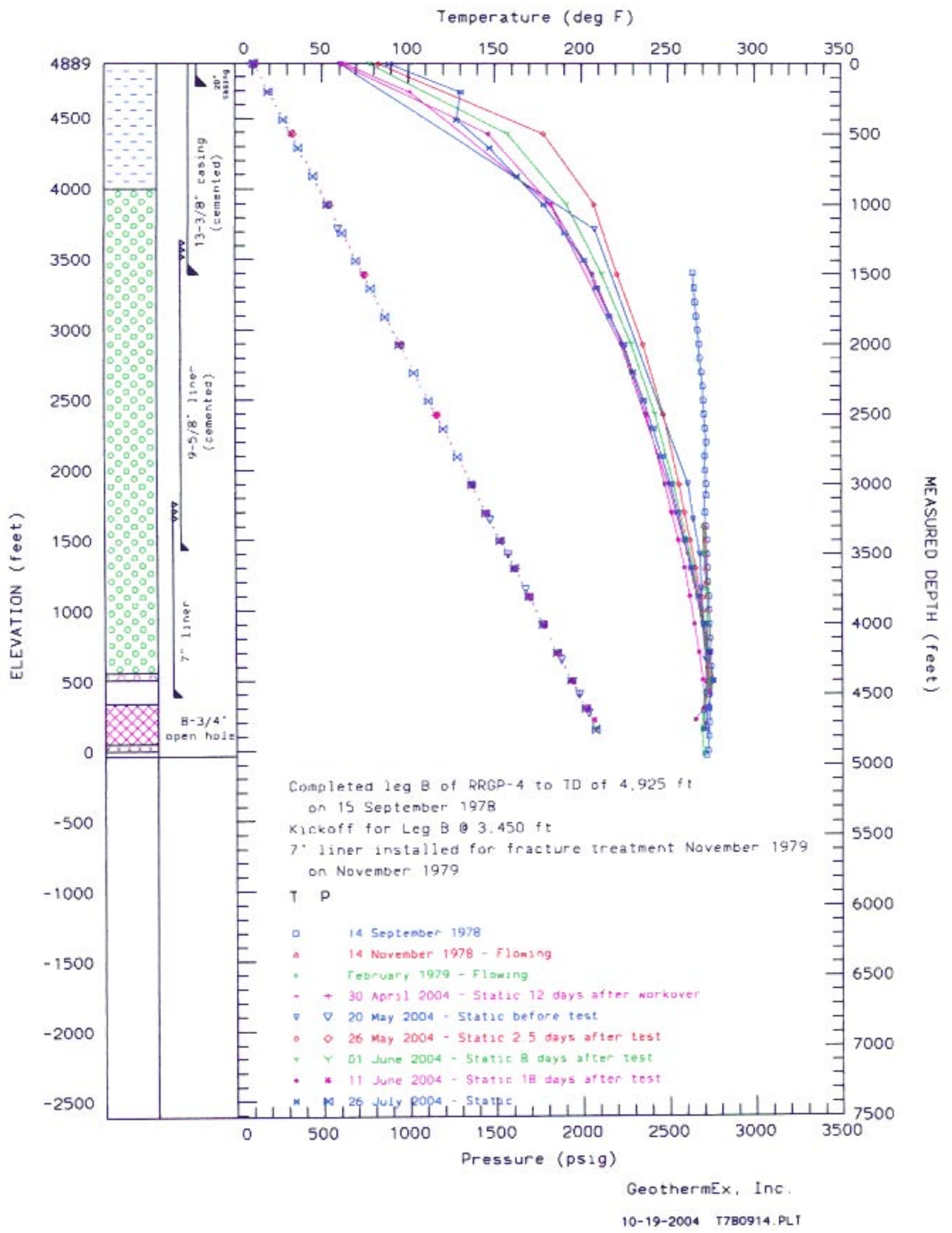




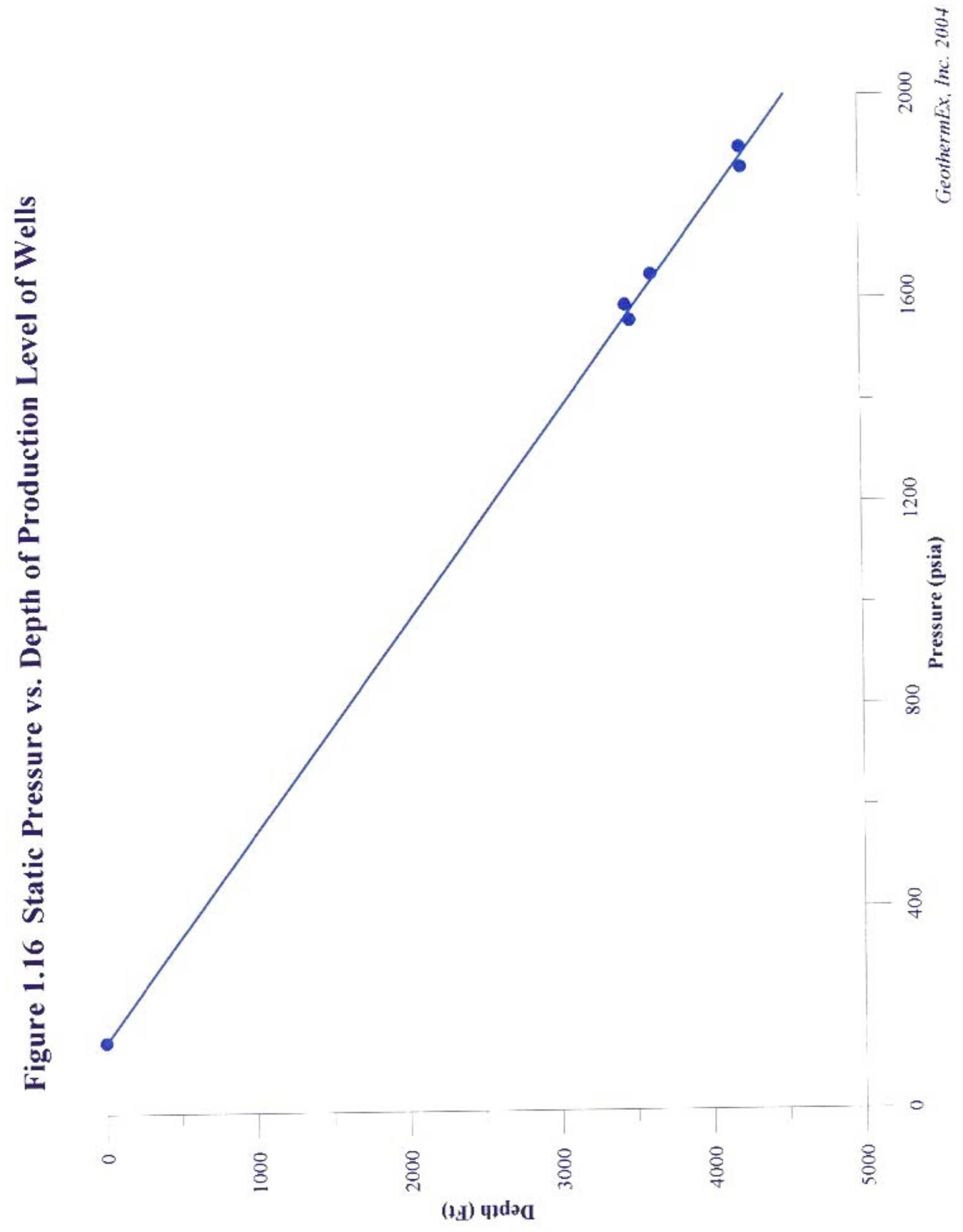



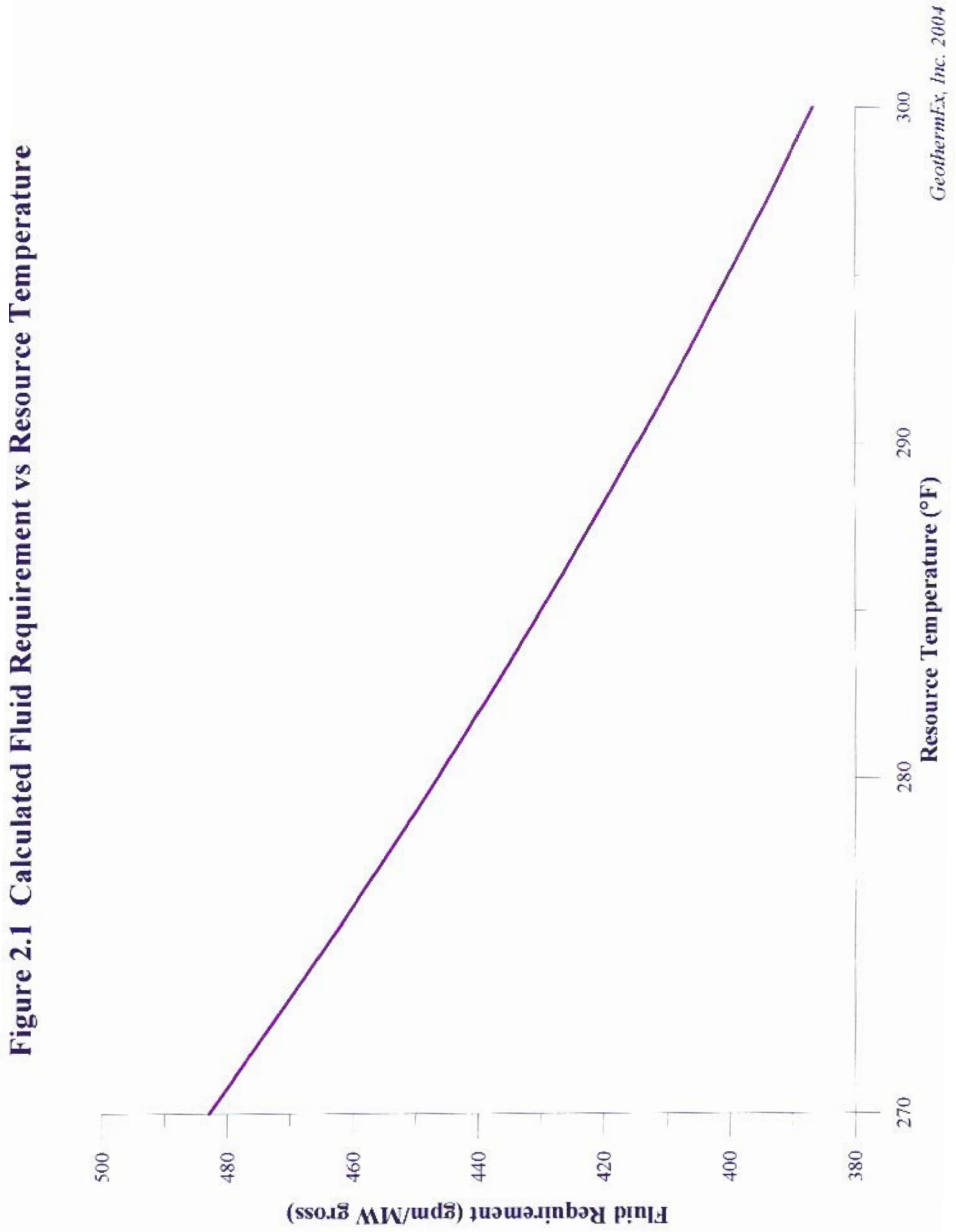


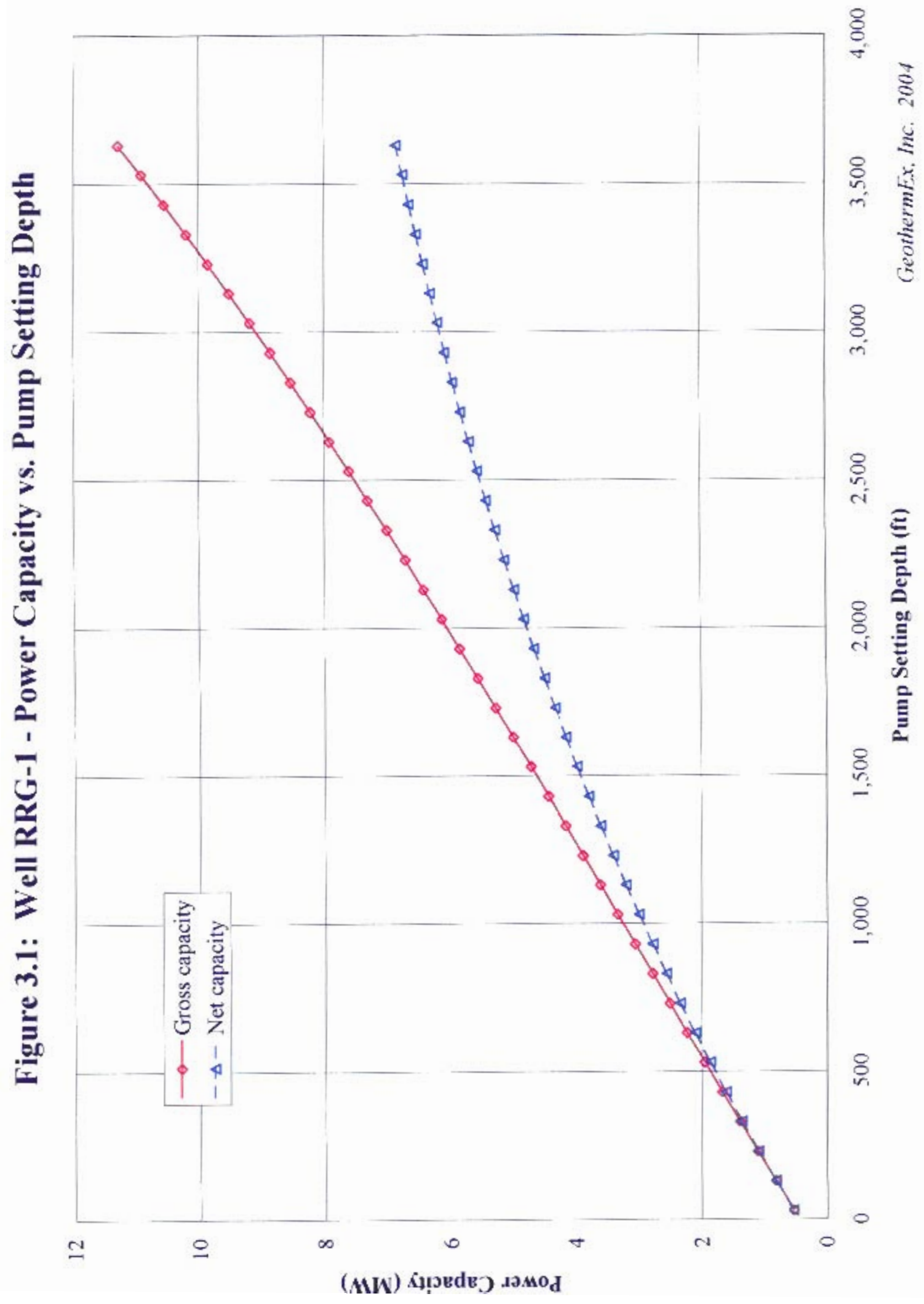




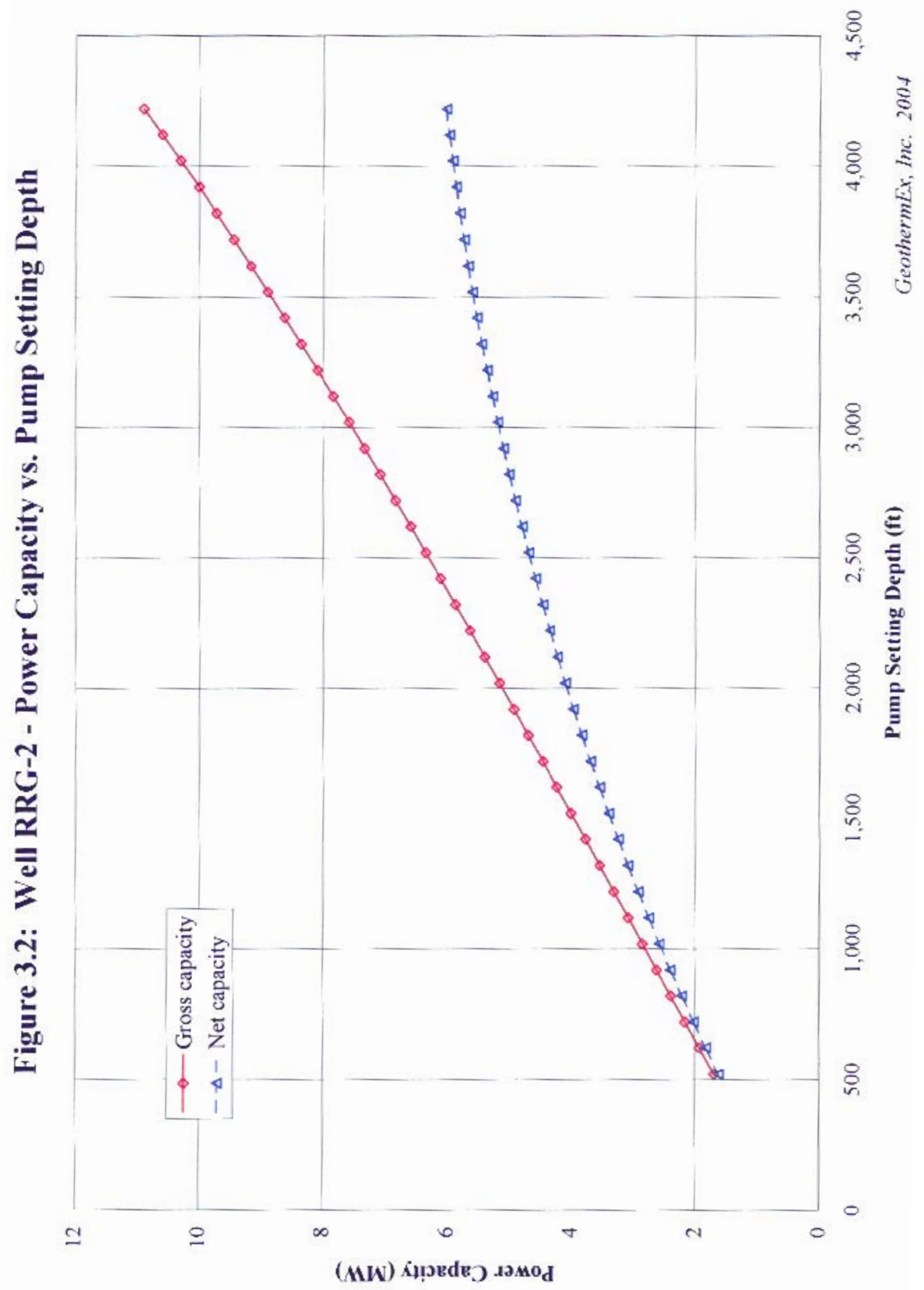




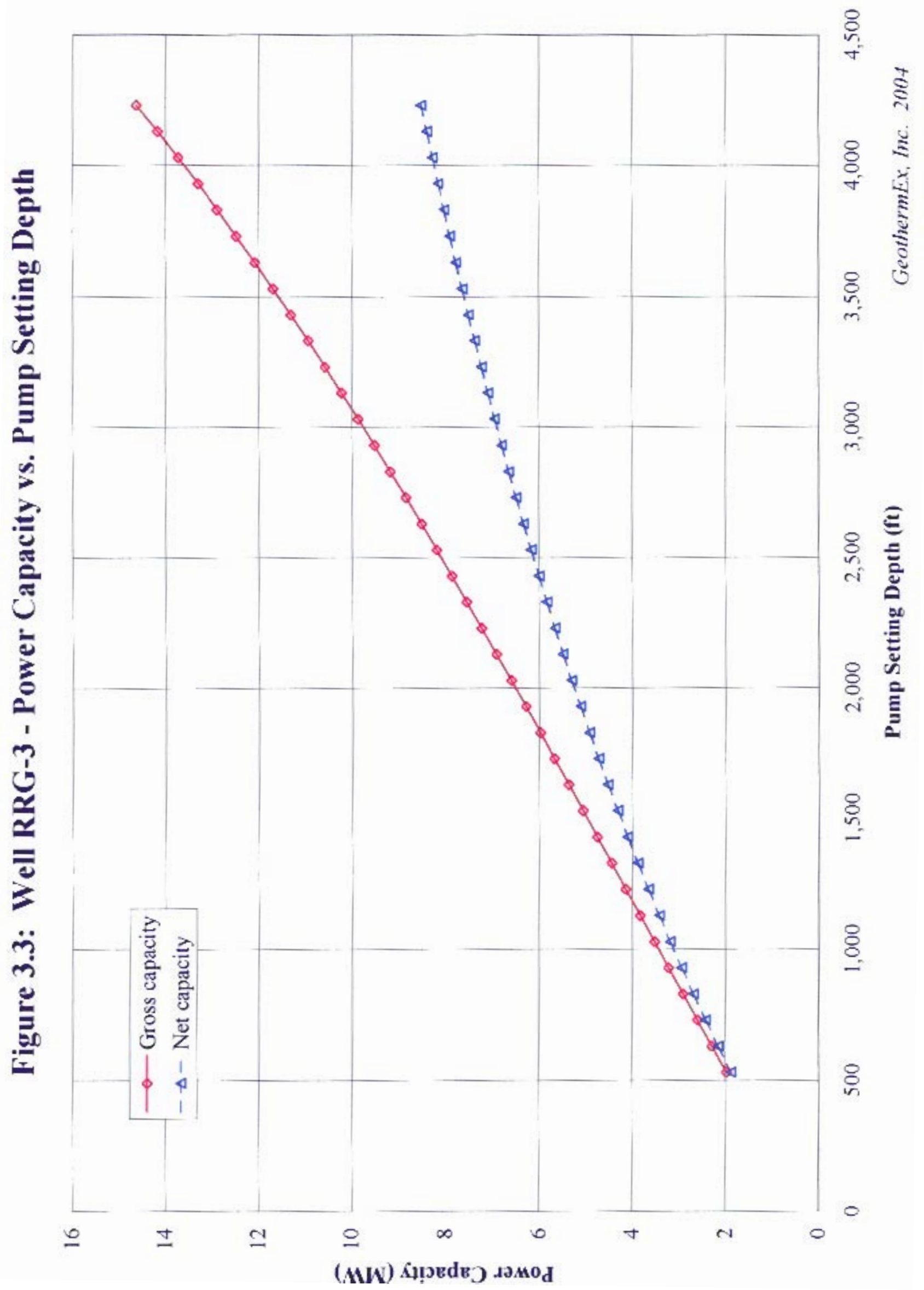




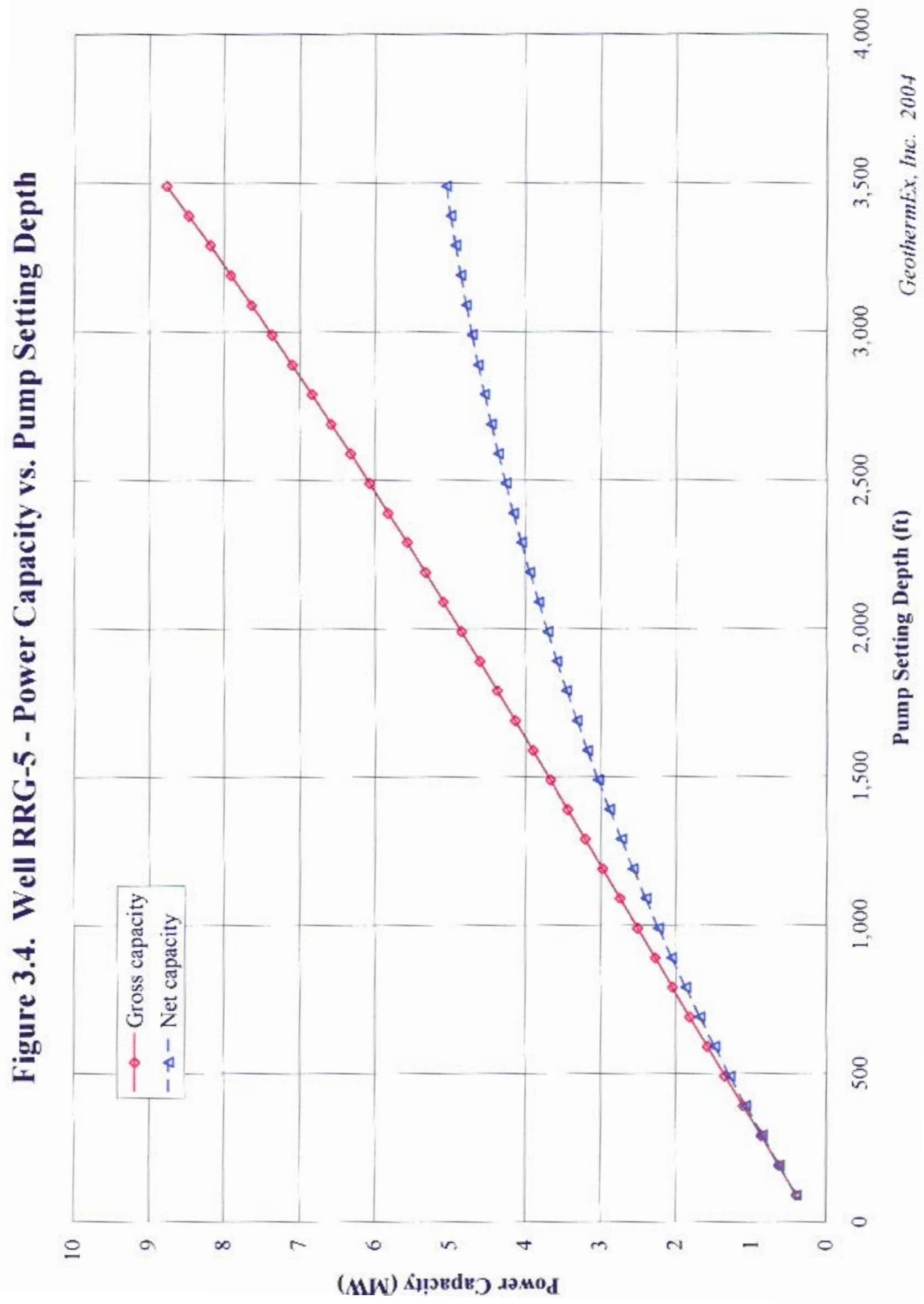




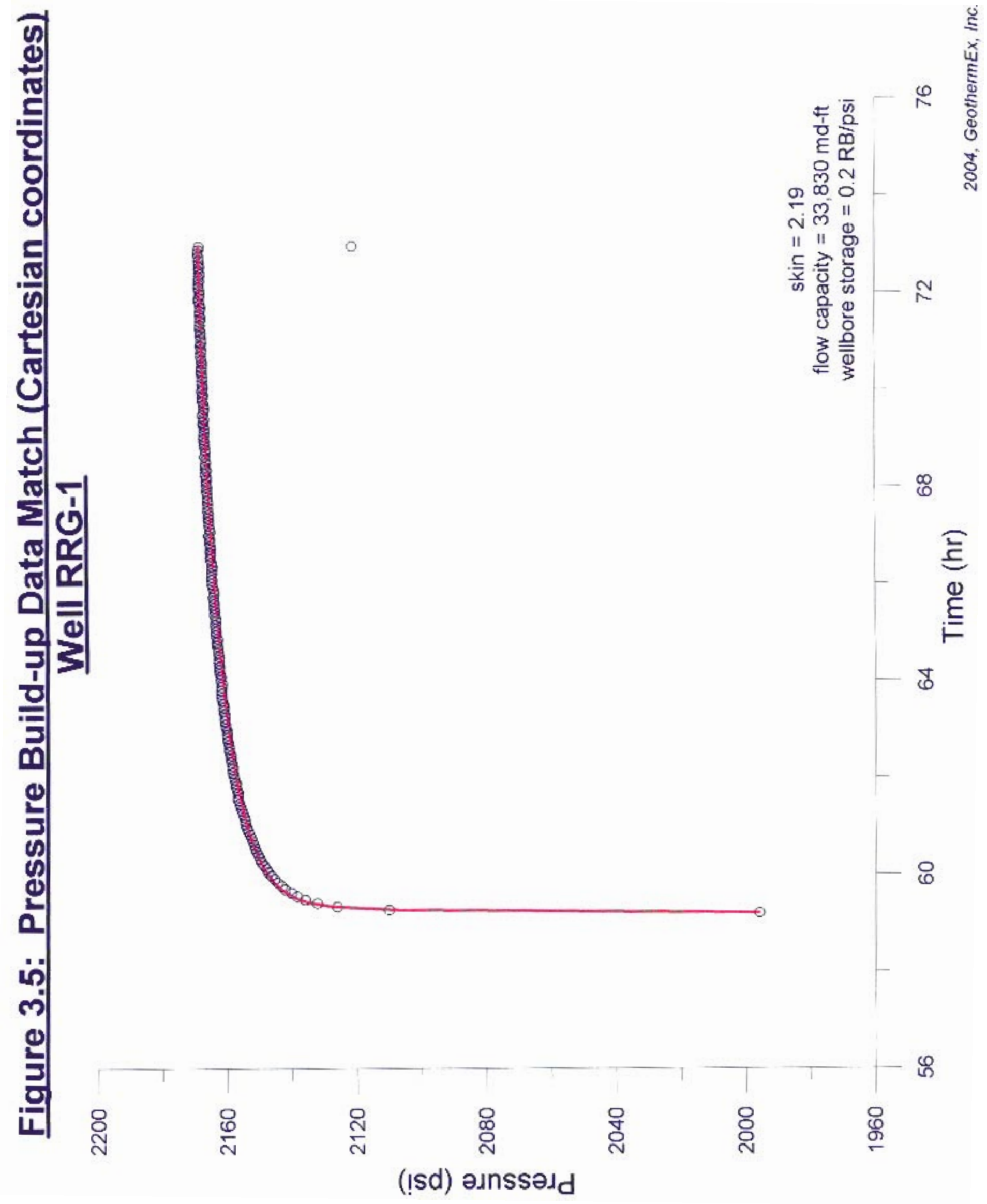



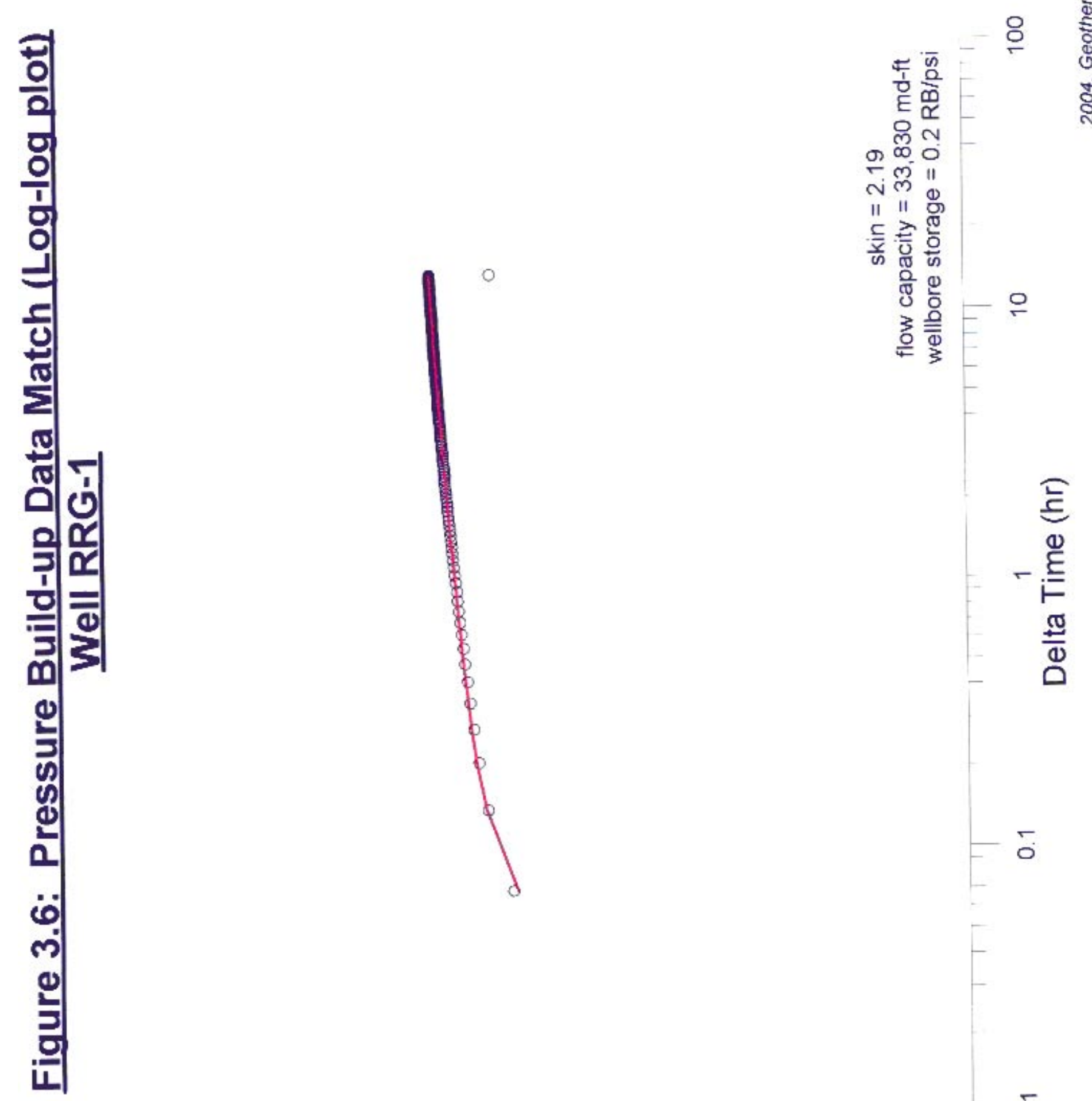

जल

त ल

11 2

क्ष的

응 ํㅣㅇ

으 으

은

들

$-\stackrel{\mathscr{E}}{E}$

$\stackrel{\Phi}{ \pm}$

\&

우

-

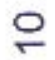

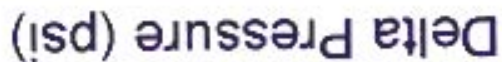




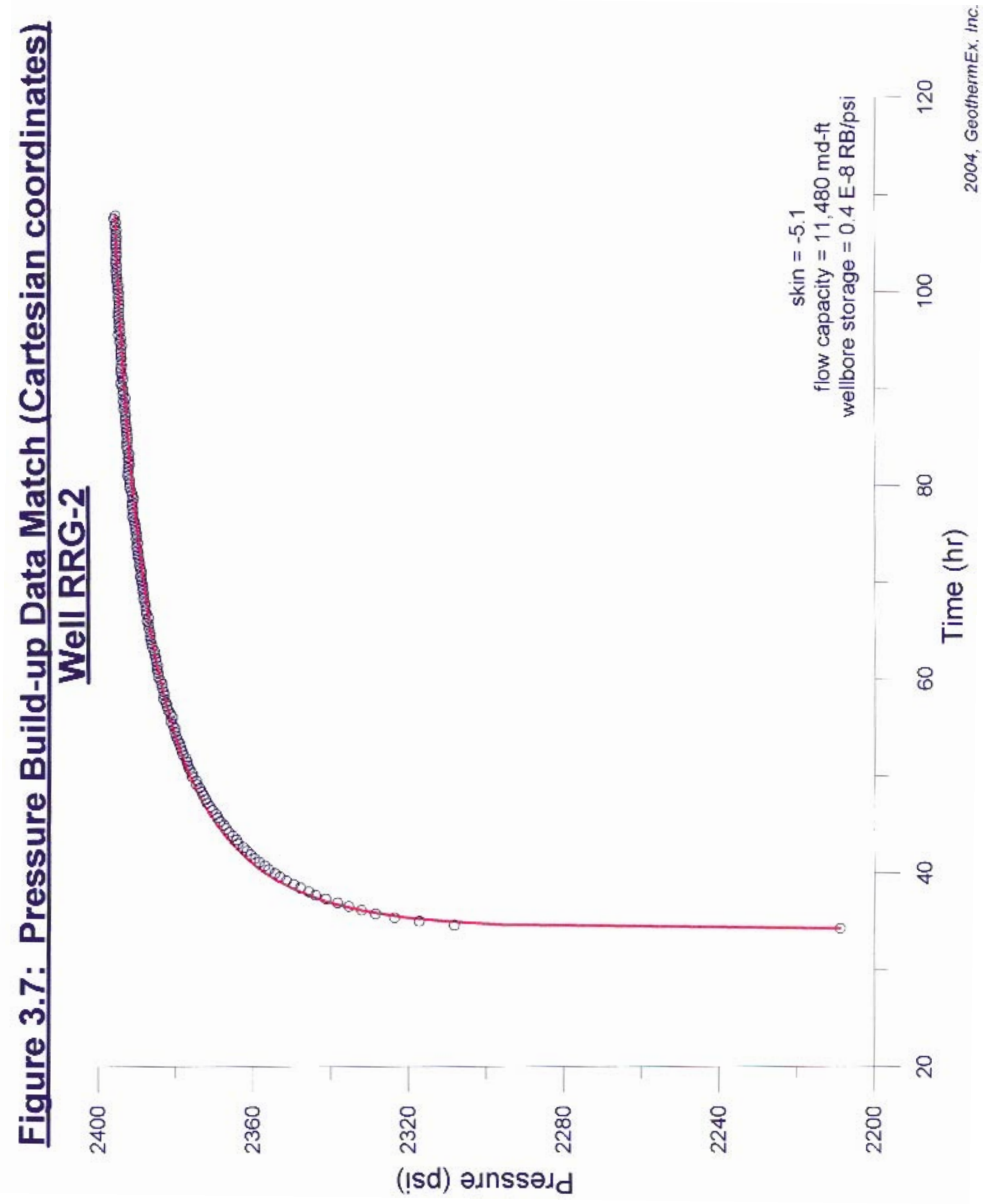



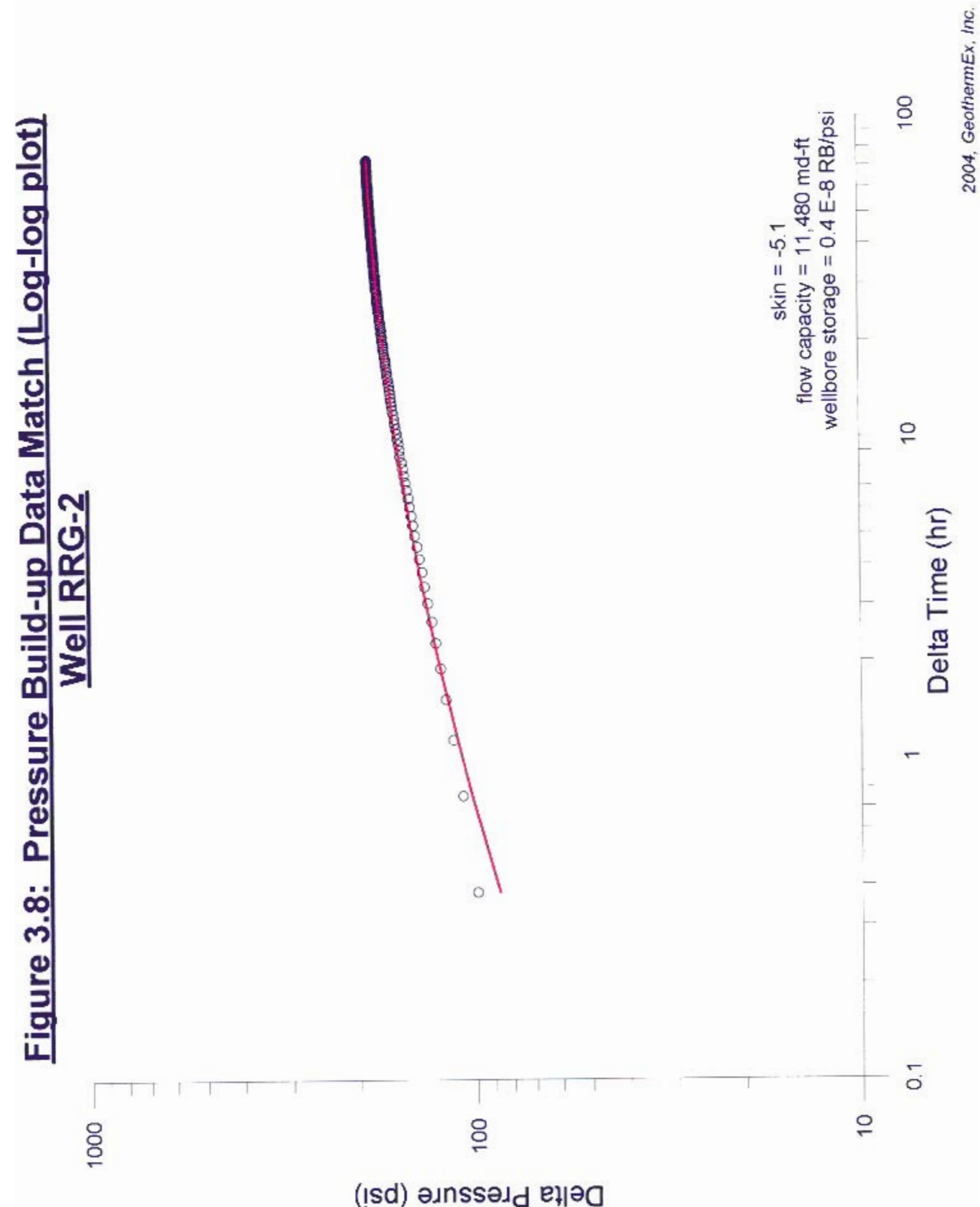


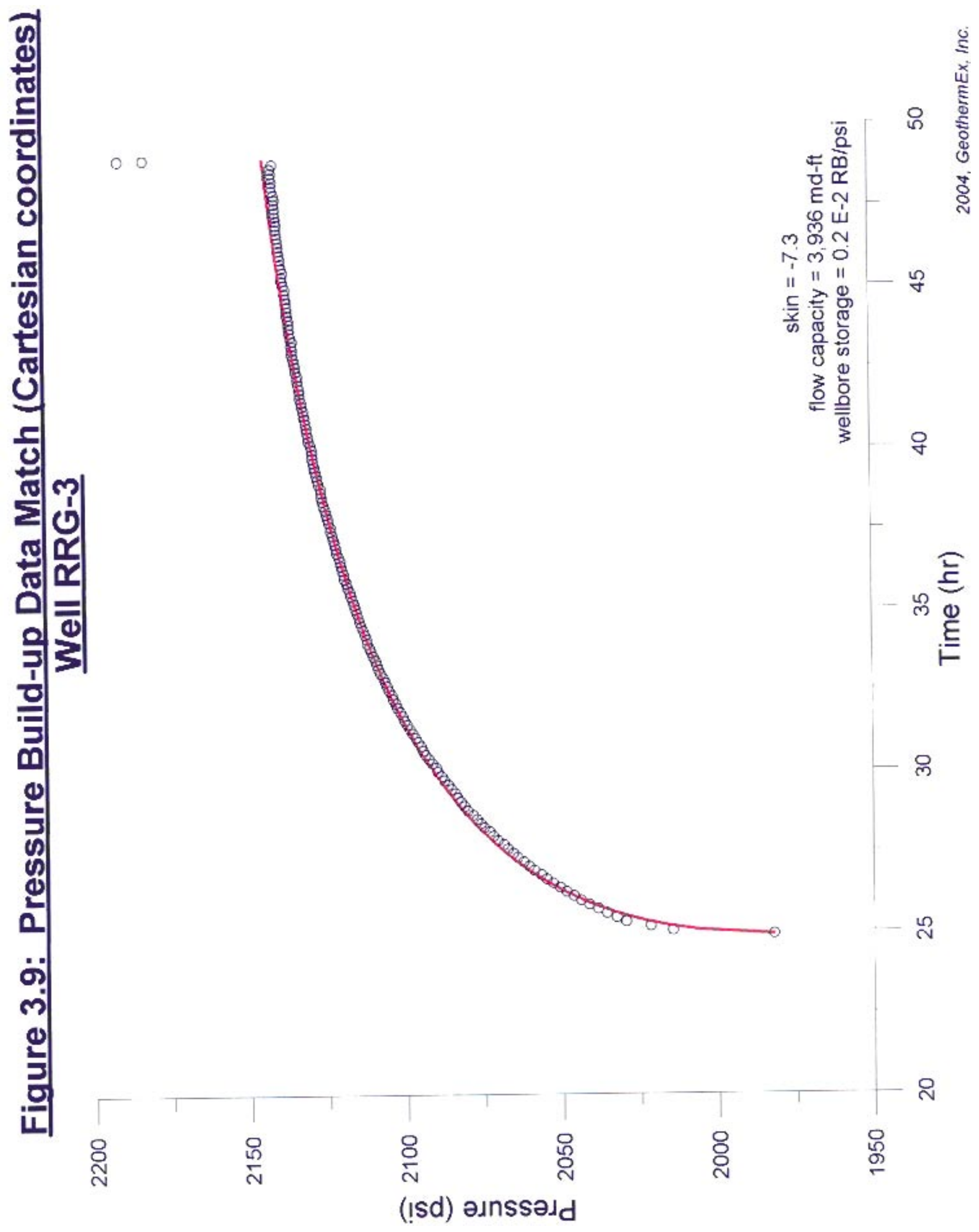




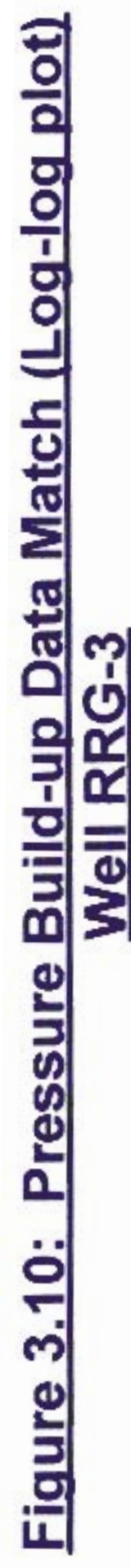

$\infty$

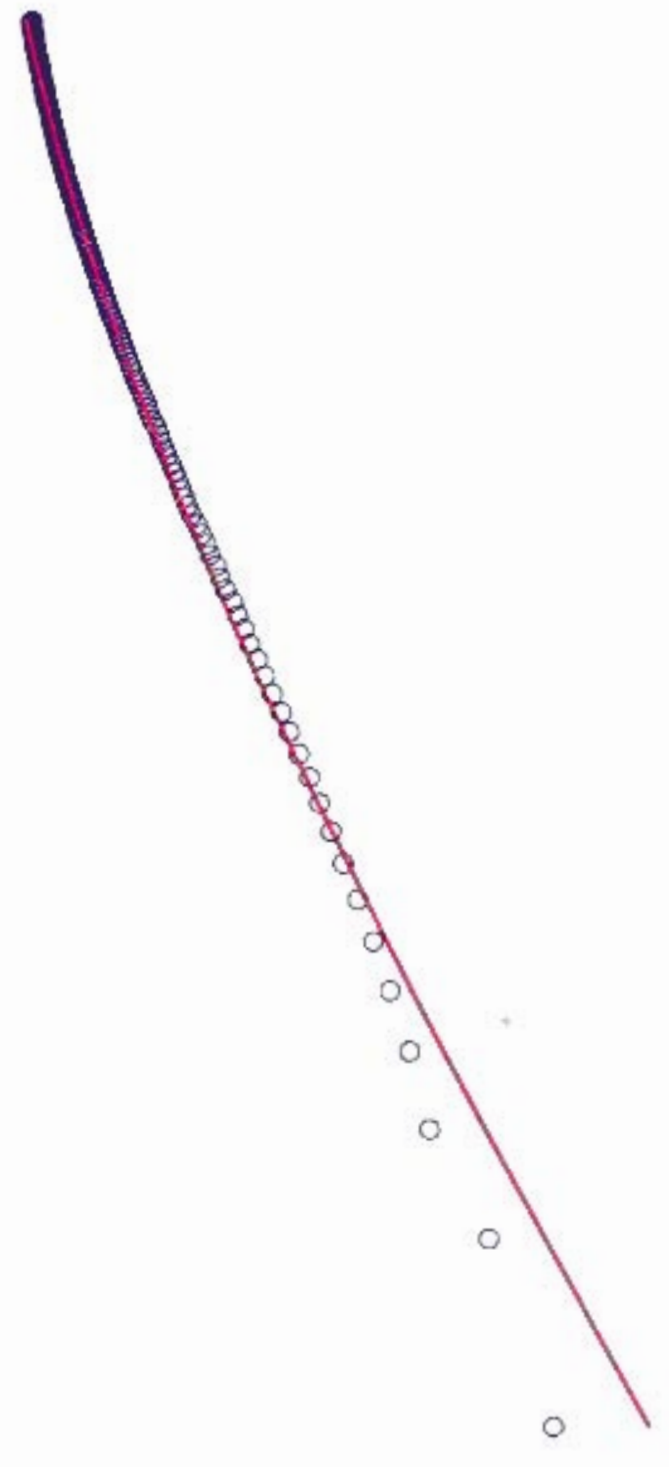

\&

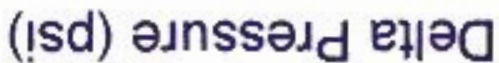

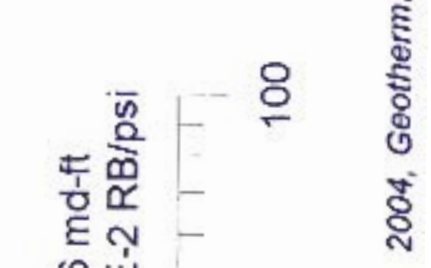

๓

जि०

IIIII

c $\geq$

등

은 옹

तु क

उ.

은 음

으

들

है

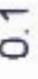

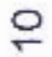




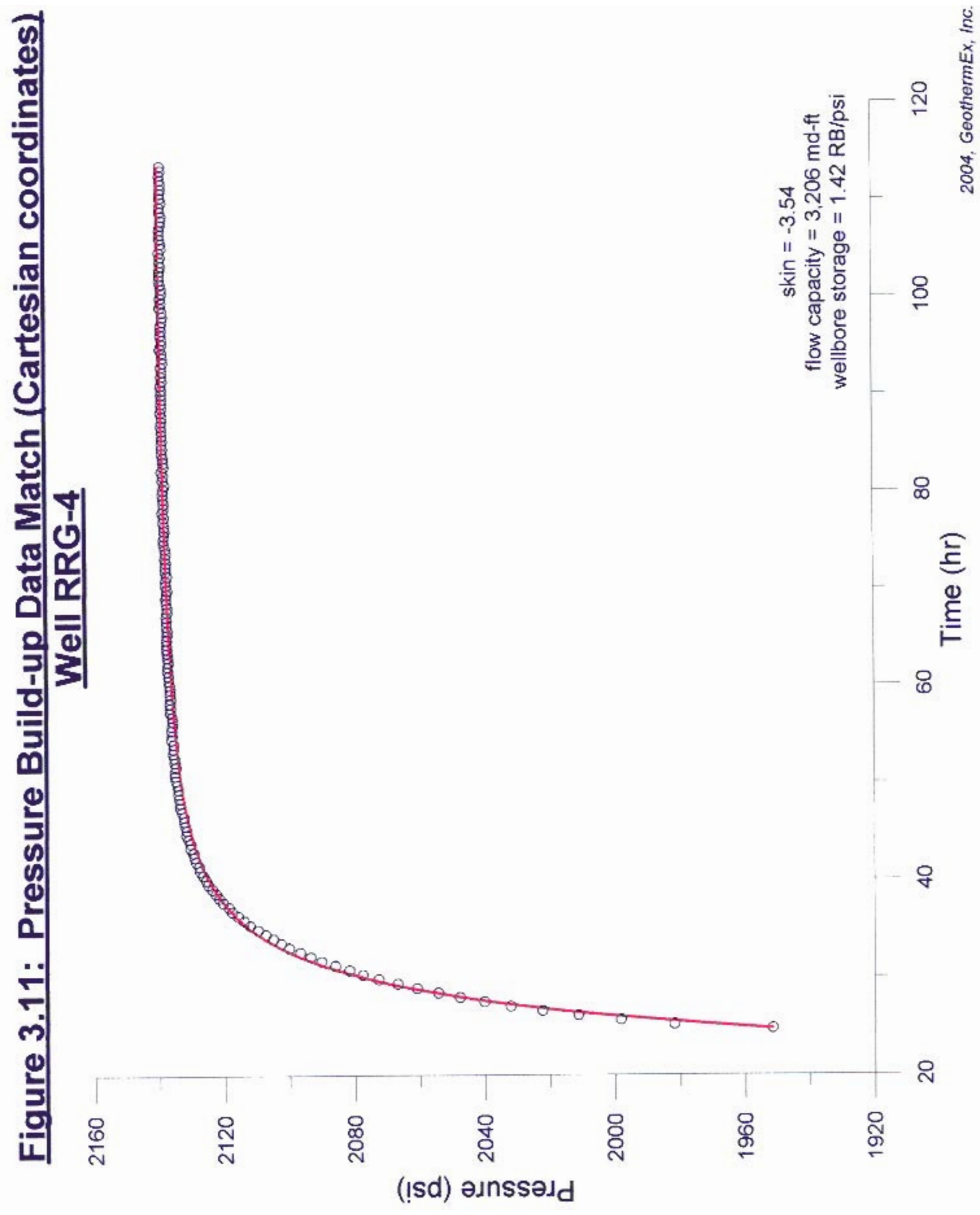



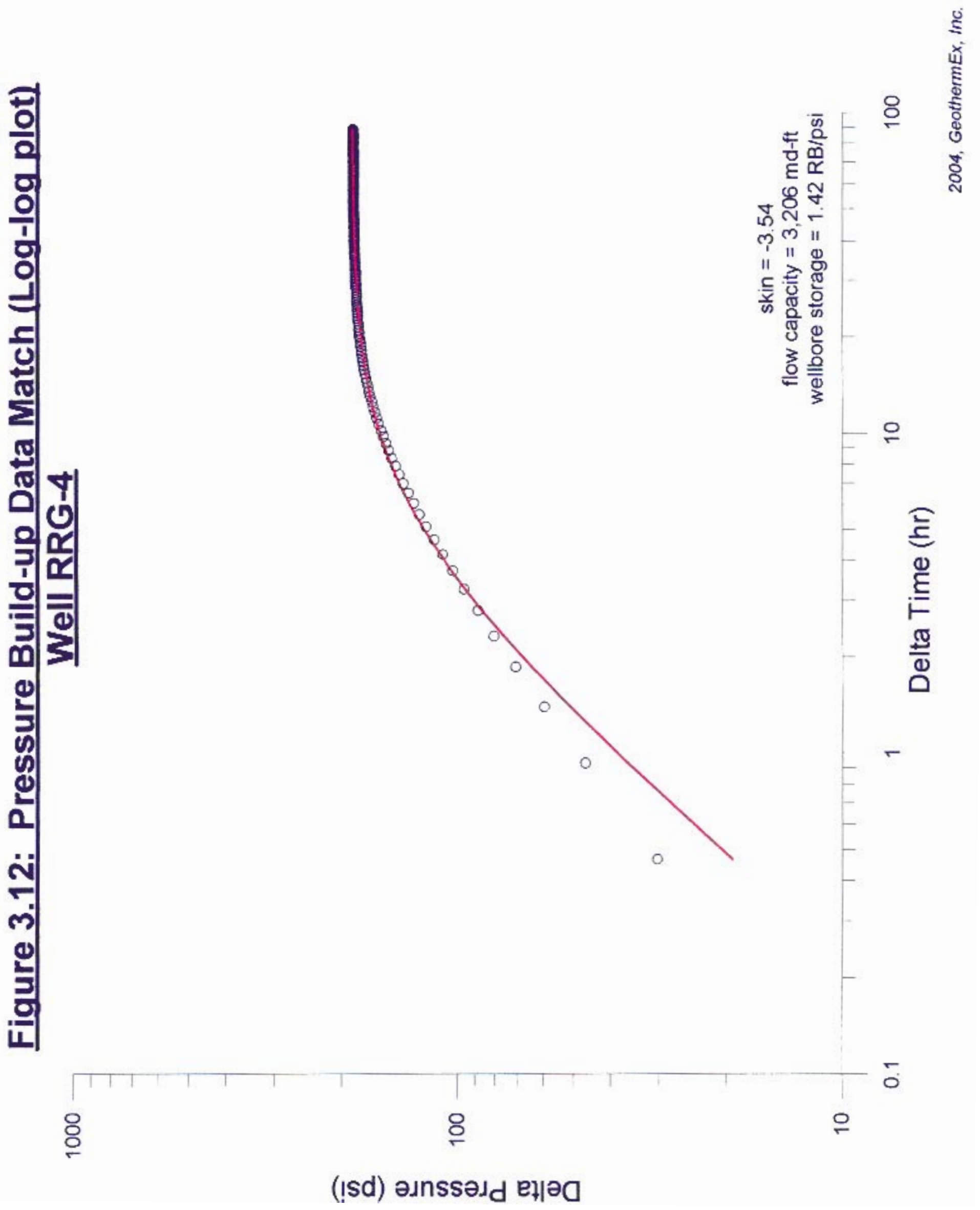


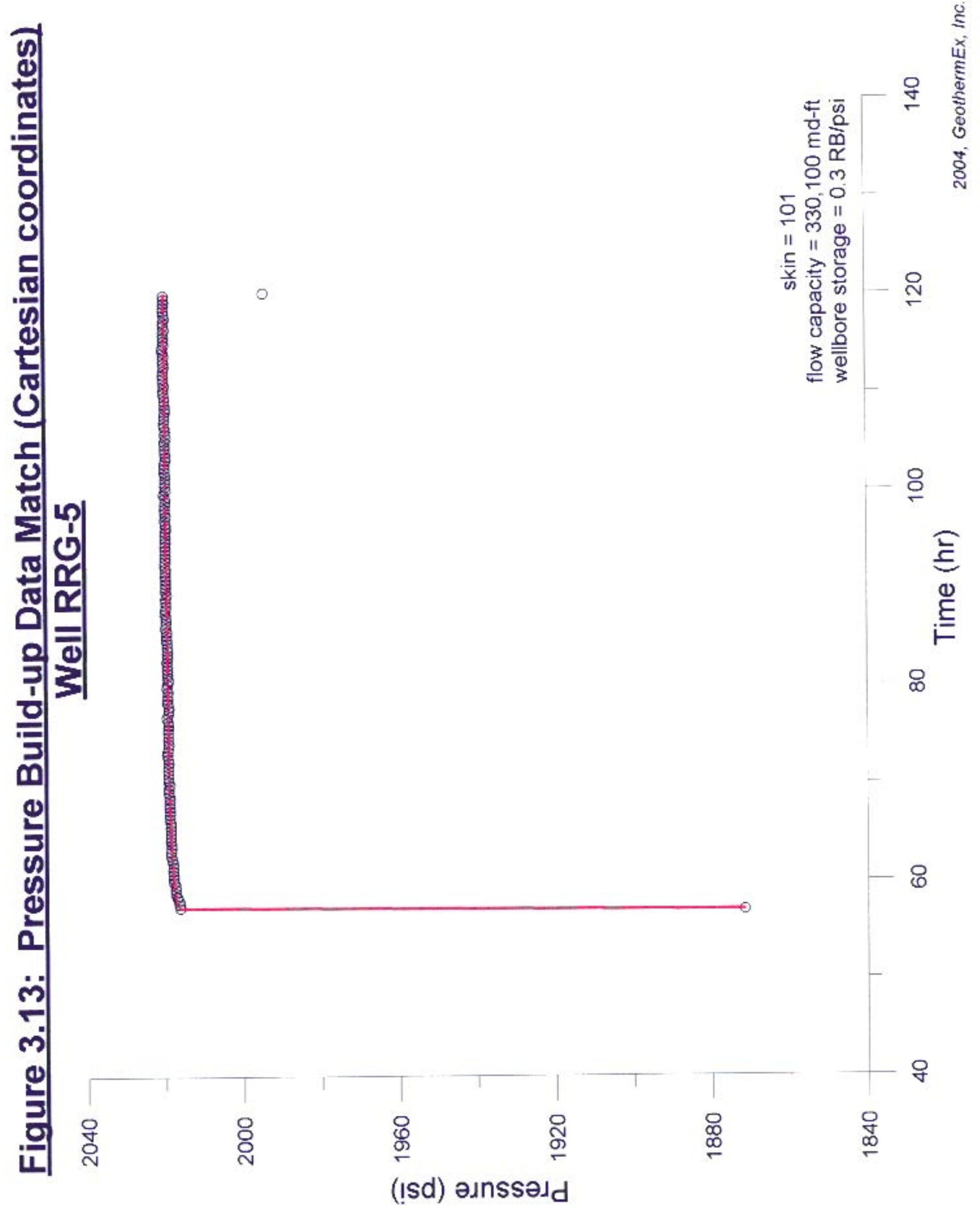



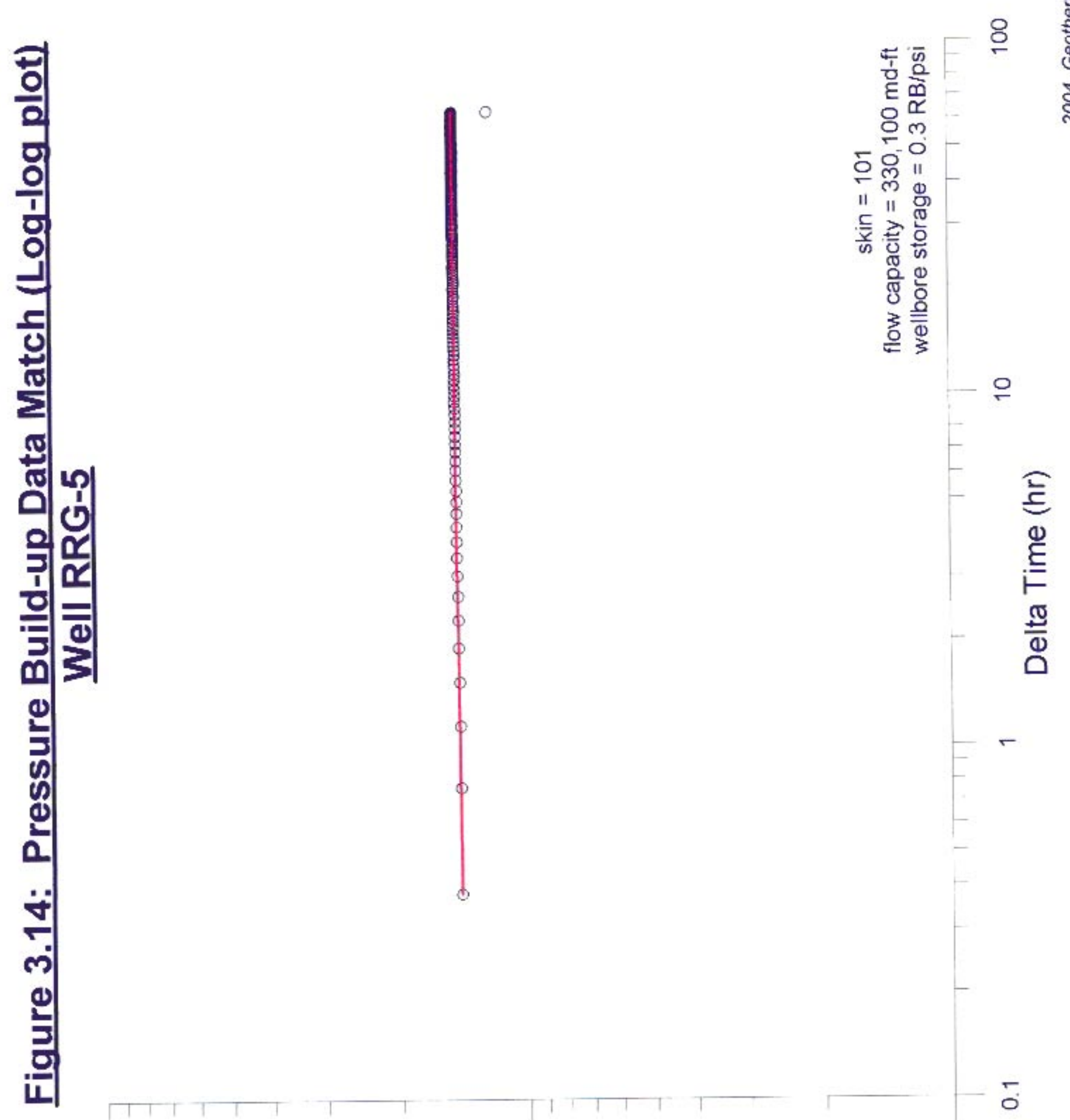

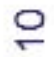

들

트

$\frac{\Phi}{ \pm}$

号

웅

(Isd) əJnssəدd 래리 


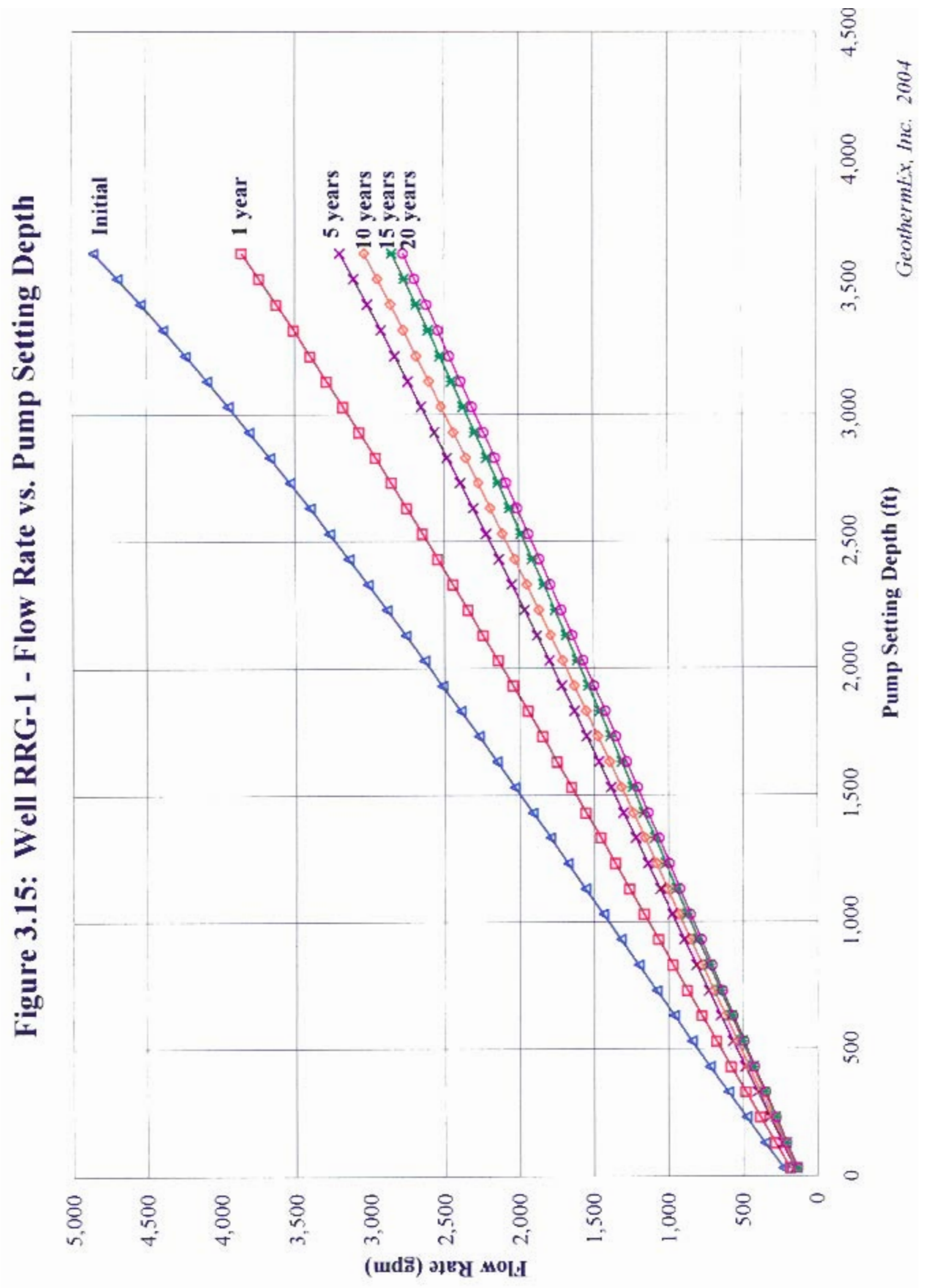




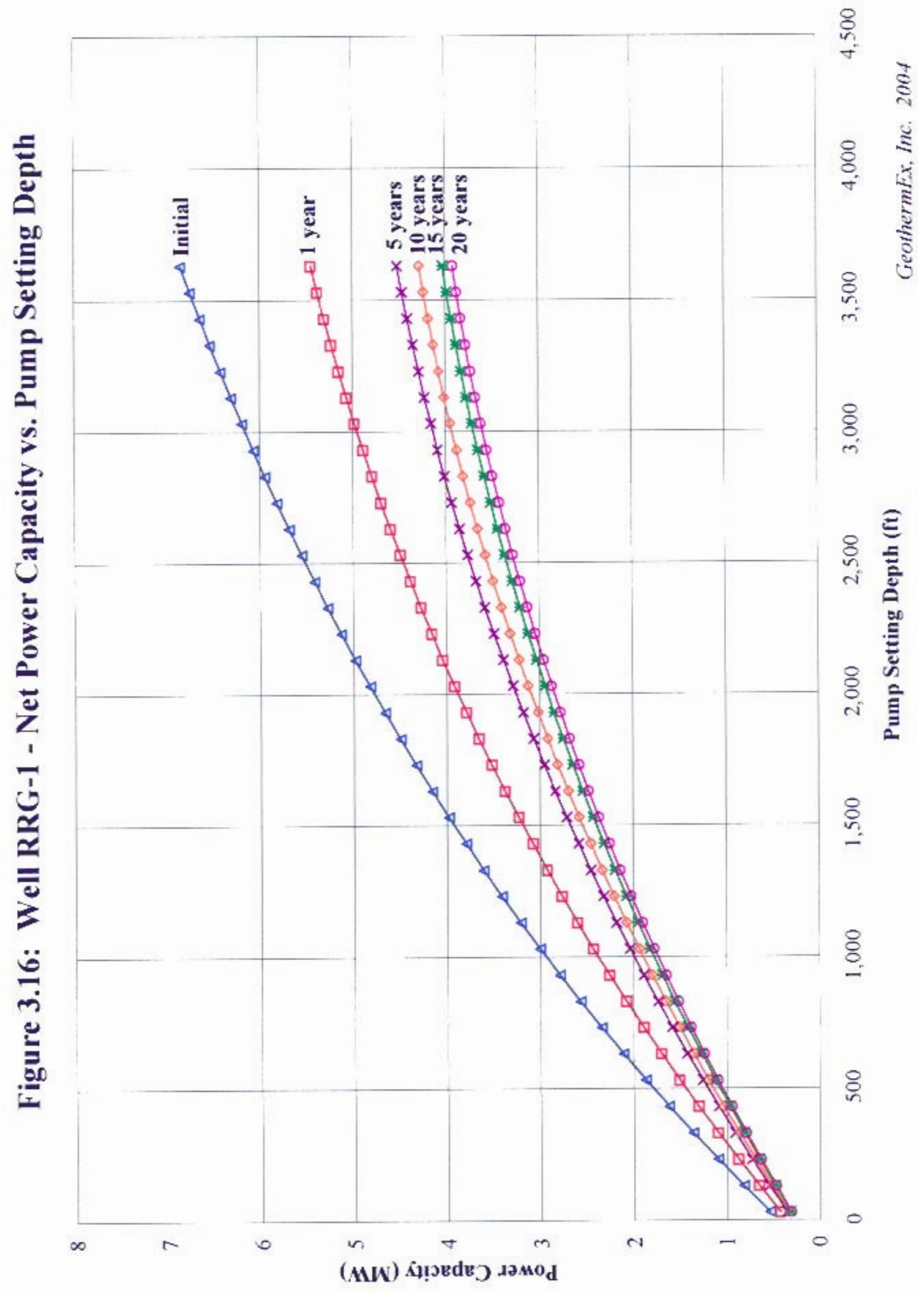




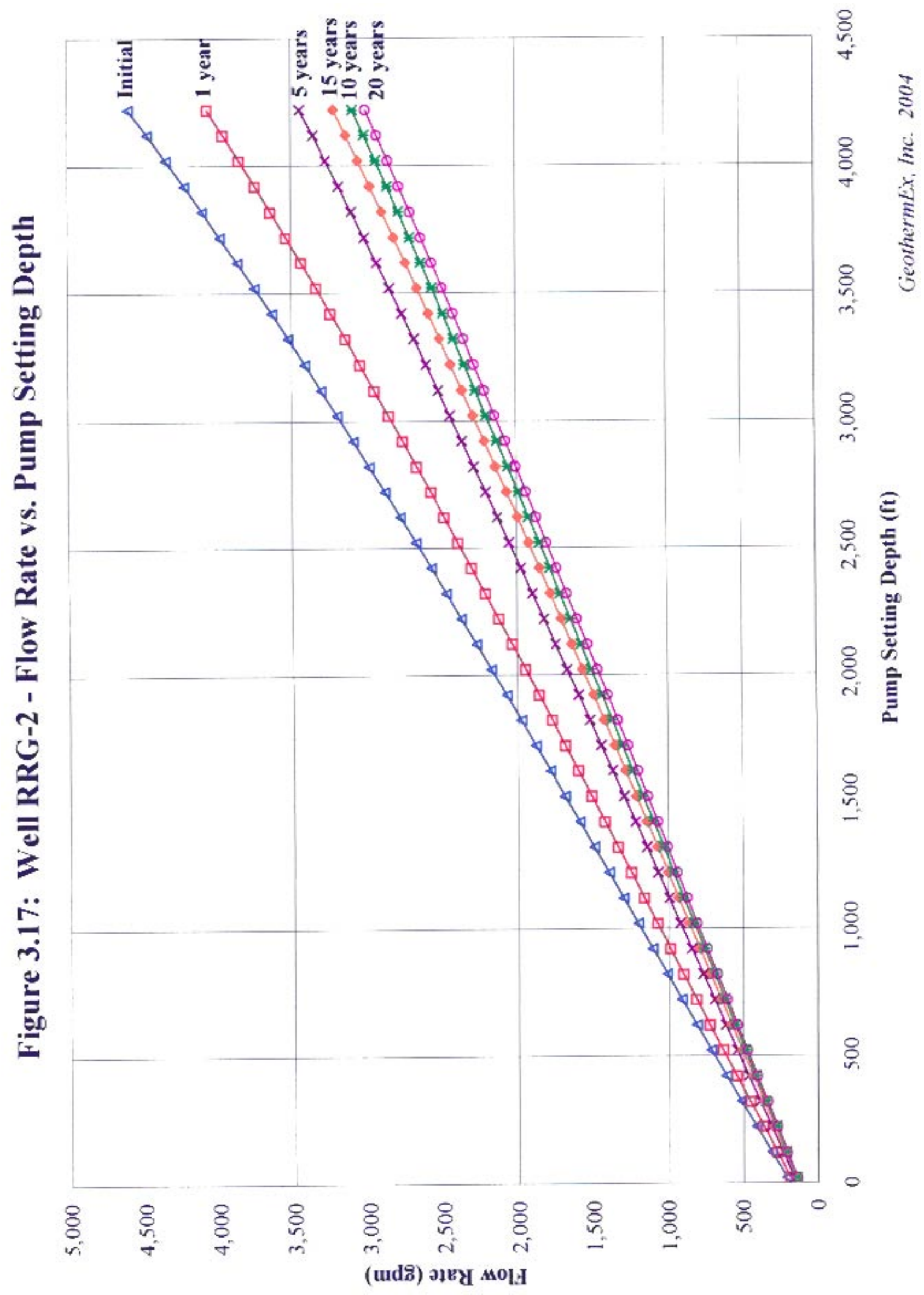




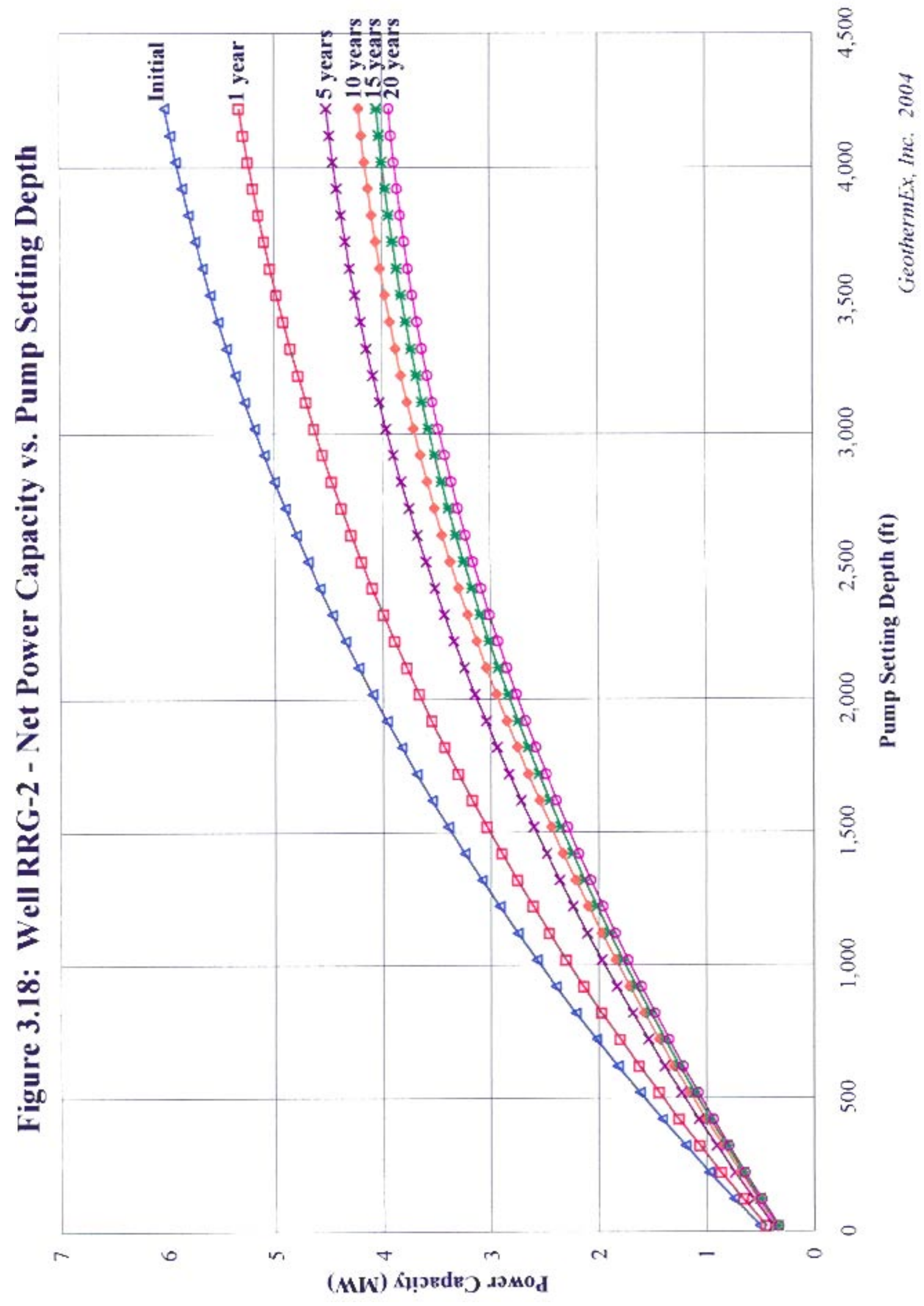




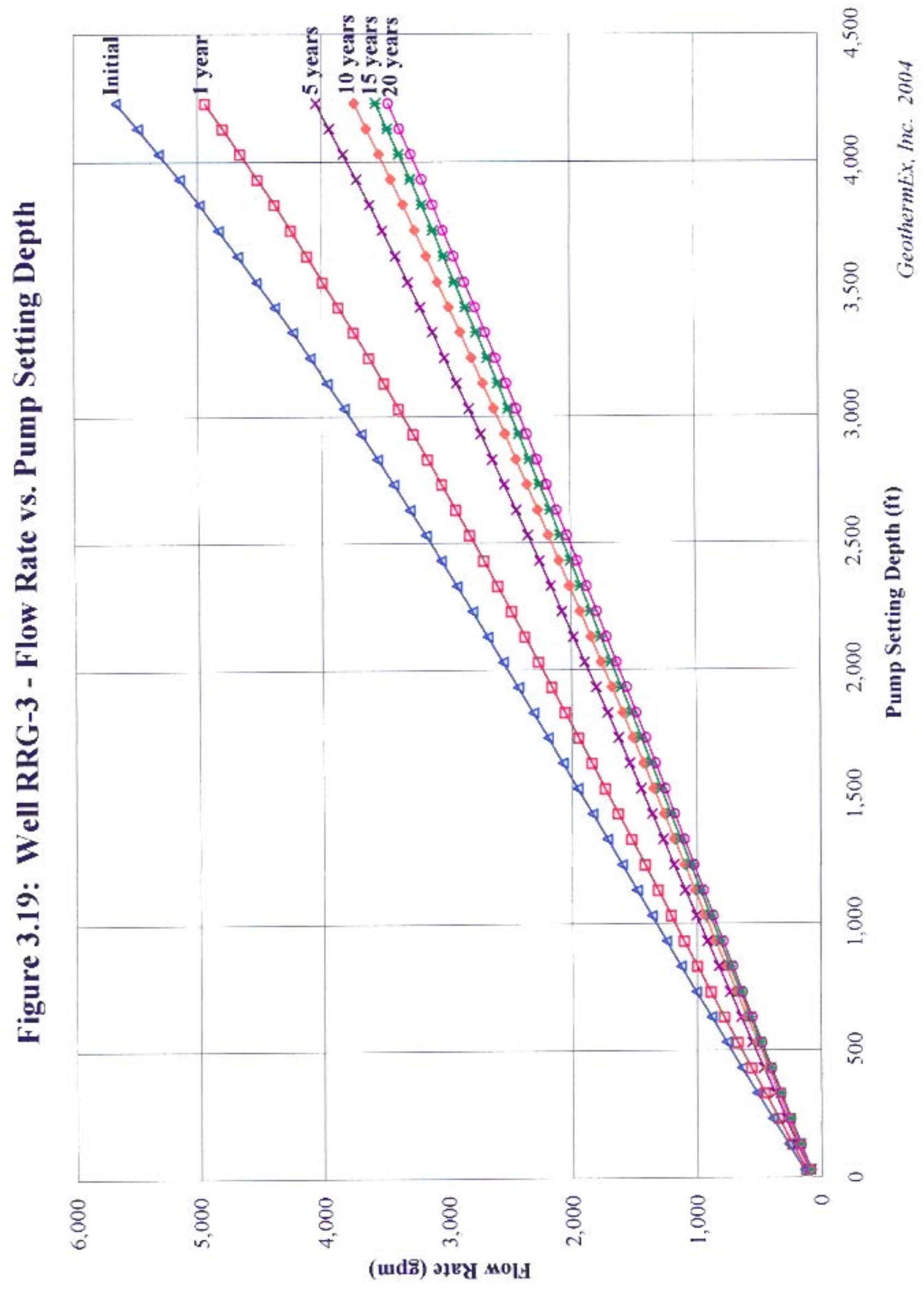




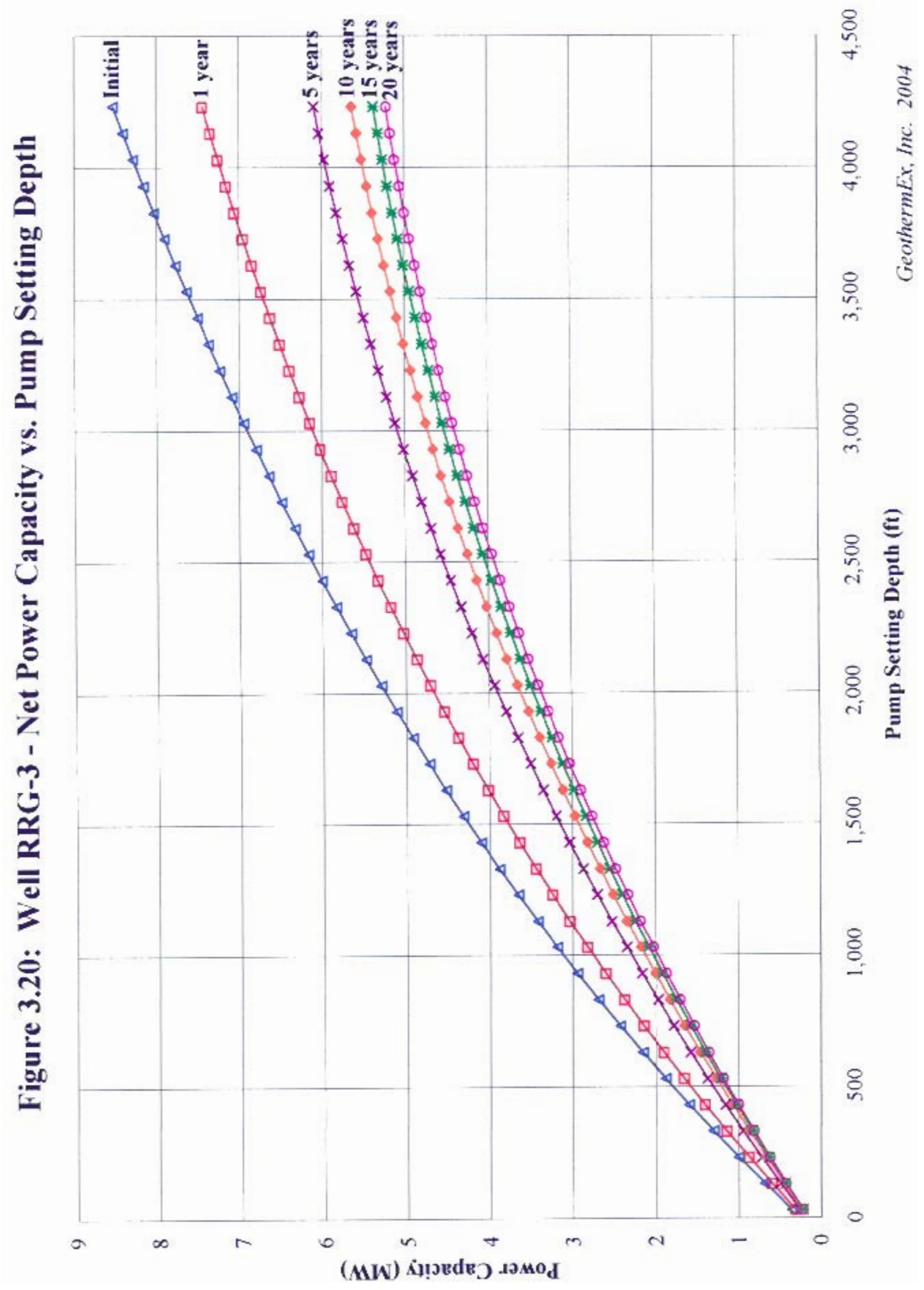




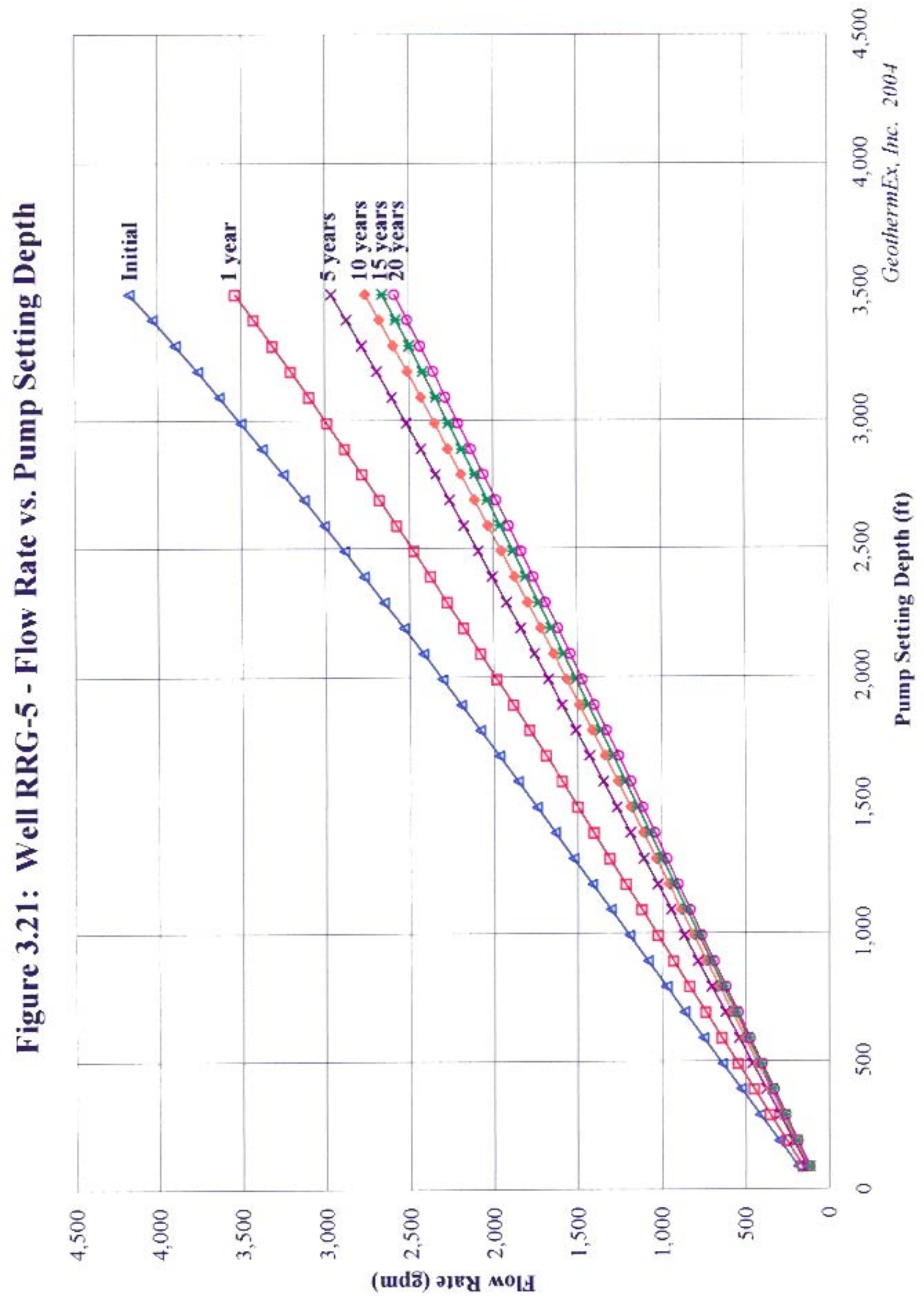




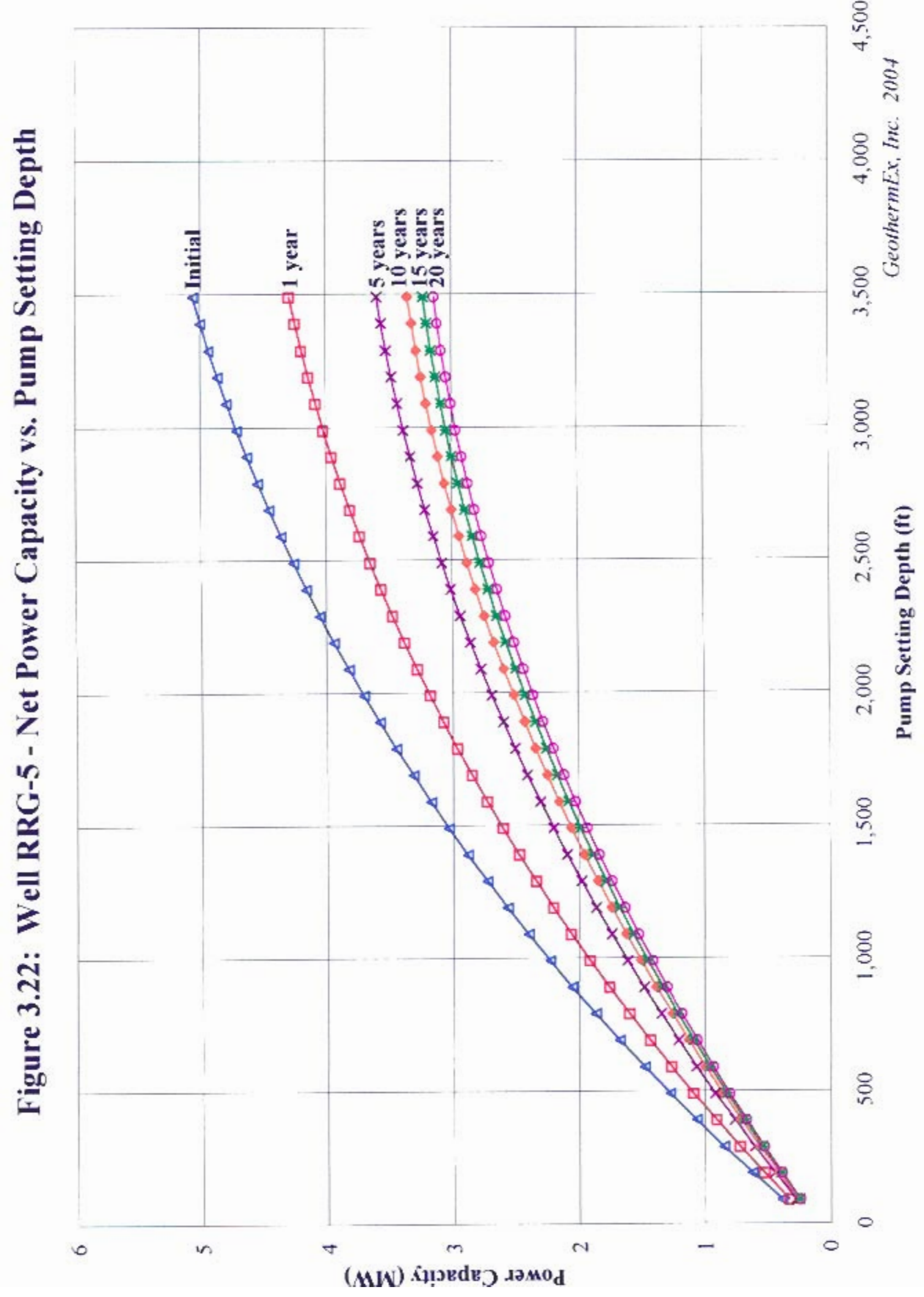



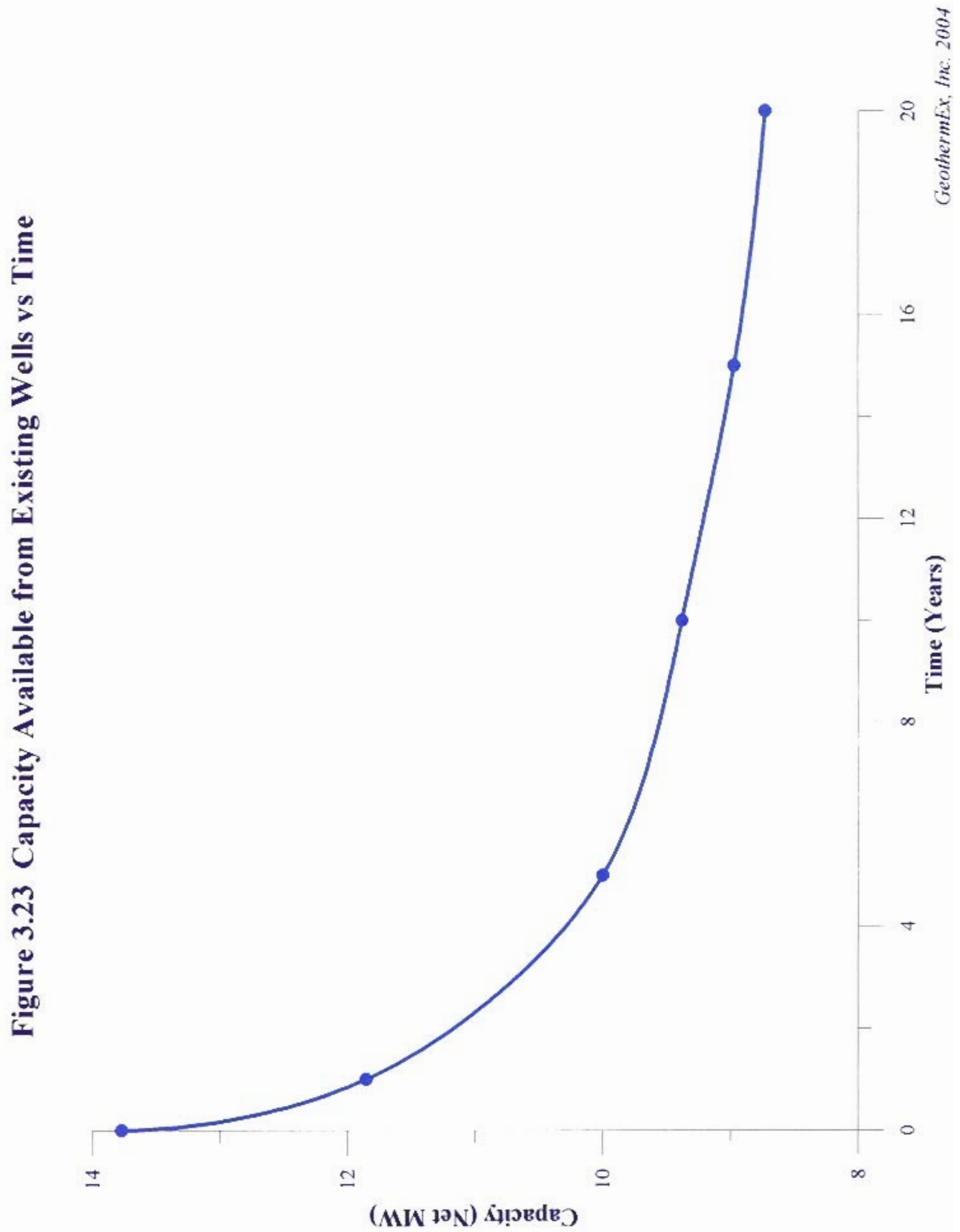


\title{
RESULTS FROM THE SHORT-TERM WELL TESTING \\ PROGRAM AT THE RAFT RIVER GEOTHERMAL
}

\author{
FIELD, CASSIA COUNTY, IDAHO
}

\author{
for \\ US Geothermal, Inc. \\ Boise, Idaho
}

by

GeothermEx, Inc.

Richmond, California

OCTOBER 2004 
RRG-4 FLOW AND PRESSURE BUILD-UP TEST 


\section{RRG-4 Flow and Pressure Buildup Test}

\section{Introduction and Summary}

A 75.5 hour flow test of RRG-4 followed by a 138-hour pressure buildup was conducted March 14 to 23, 2006. Wells RRG-1, RRG-2, RRG-5, and RRG-11 were instrumented for pressure interference measurement during the flow test. The memo presents the pressure transient results of the flow test and the four pressure observation wells.

\section{Flow Test Results}

The rate history is presented below in Figure 1 . The well flow rate was restricted to $1800 \mathrm{gpm}$ due to surface equipment limitations. The flow duration was 75.75 hours with an average flowrate of $1,681 \mathrm{gpm}$ and a cumulative production of 7,614,400 gallons.

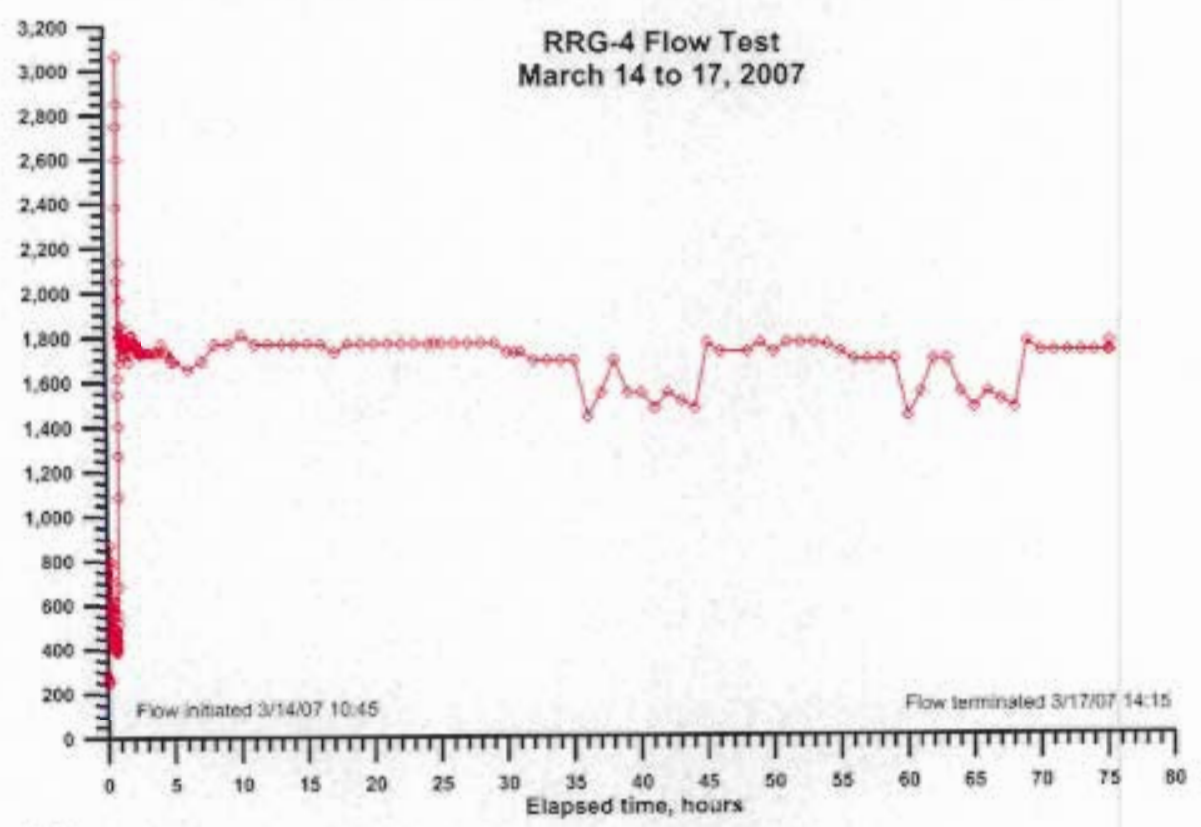

Figure 1-RRGE-4 flow rate history, March 14 to $17,2007$.

\section{Pressure Drawdown}

The pressure/temperature tool was set at $4,500 \mathrm{ft} \mathrm{MD}$ for the first part of the test and then reset at $2,850 \mathrm{ft} \mathrm{MD}$ for the duration of the flow test. The pressure data was adjusted for a datum at 4,500 $\mathrm{ft}$ from the change in tool setting depth for the transient analysis. A flowing traverse of the well was made using the pressure/temperature tool to measure the flowing well temperatures for determination of the stagnation enthalpy for flow rate and flash calculations. The flowing temperature was from $278.2^{\circ} \mathrm{F}$ to $279.6^{\circ} \mathrm{F}$.

The pressure drawdown and buildup response was analyzed using a homogenous radial flow model and a finite conductivity fracture in a dual porosity system. The pressure buildup data clearly shows the presence of a constant pressure boundary with the pressure derivative declining after about four hours into the test. The results are summarized below and the Saphir program output is in Appendix A. 
Homogeneous flow model

$$
\begin{aligned}
& k h=77,000 \mathrm{mD}-\mathrm{ft} \\
& \text { skin }=-3.53 \\
& \mathrm{C}=0.00299 \mathrm{bbl} / \mathrm{psi} \\
& \mathrm{L}=15,000 \mathrm{ft} \text { to constant pressure fault }
\end{aligned}
$$

The homogeneous flow model analysis was conducted to determine if infinite acting radial flow behavior was present. The pressure transient response is poorly characterized by this flow model so another flow model was used.

Finite conductivity, dual porosity flow model

$$
\begin{aligned}
& k h=63,950 \mathrm{mD}-\mathrm{ft} \\
& \text { Omega }=1 \mathrm{E}-4 \\
& \text { Lambda }=2.96 \mathrm{E}-7 \\
& \mathrm{C}=2.9 \mathrm{E}-4 \mathrm{bbl} / \mathrm{psi} \\
& \mathrm{X}_{\mathrm{f}}=50 \mathrm{ft} \\
& \mathrm{Fc}=13,950 \mathrm{md}-\mathrm{ft} \\
& \mathrm{L}=2,200 \mathrm{ft} \text { to a constant pressure fault }
\end{aligned}
$$

The finite conductivity, dual porosity flow model is consistent with the general geologic model and is considered to be the preferred analysis.

\section{Pressure Buildup}

As in the pressure drawdown test, the pressure/temperature tool was set at $2,850 \mathrm{ft} \mathrm{MD}$. The pressure buildup response was again analyzed using a homogenous radial flow model and a finite conductivity fracture and a dual porosity system. The pressure data clearly shows the presence of a constant pressure boundary distant from the well with the pressure derivative declining after about four hours into the pressure buildup.

Homogeneous flow model

$$
\begin{aligned}
& k h=92,850 \mathrm{mD}-\mathrm{ft} \\
& \text { skin }=-5.78 \\
& \mathrm{C}=2.13 \mathrm{E}-4 \mathrm{bbl} / \mathrm{psi} \\
& \mathrm{L}=3,690 \mathrm{ft} \text { to constant pressure fault }
\end{aligned}
$$

Finite conductivity, dual porosity flow model

$$
\begin{aligned}
& k h=95,550 \mathrm{mD}-\mathrm{ft} \\
& \text { Omega }=0.00265 \\
& \text { Lambda }=1.7 \mathrm{E}-5 \\
& \mathrm{C}=3.35 \mathrm{E}-5 \mathrm{bbl} / \mathrm{psi} \\
& \mathrm{X}_{\mathrm{f}}=5 \mathrm{ft} \\
& \mathrm{Fc}=1,390 \mathrm{md}-\mathrm{ft} \\
& \mathrm{L}=1,130 \mathrm{ft} \text { to a constant pressure fault }
\end{aligned}
$$

\section{Discussion}

The finite conductivity dual porosity flow regime is preferred from geologic considerations. Leg $\mathrm{C}$ is targeted into the Bridge fault zone and intersected zones of lost circulation during drilling. A 
comparison of the pressure drawdown and pressure buildup pressure transient results using the finite conductivity, dual porosity model are in very good agreement and indicate a reservoir $k h$ of about $95,000 \mathrm{mD}-\mathrm{ft}$ from the pressure buildup test. RRGE-4, leg $\mathrm{C}$ is completed into a fracture system with a fracture permeability of $1,390 \mathrm{mD}$ - $\mathrm{ft}$ and a very short apparent fracture half-length of about $5 \mathrm{ft}$. A constant pressure feature is noted about $1130 \mathrm{ft}$ away from the well. The productivity index from the pressure buildup is estimated at $12.38 \mathrm{gpm} / \mathrm{psi}$. A comparison of the finite conductivity model results with the measured data is presented in Figure 2.

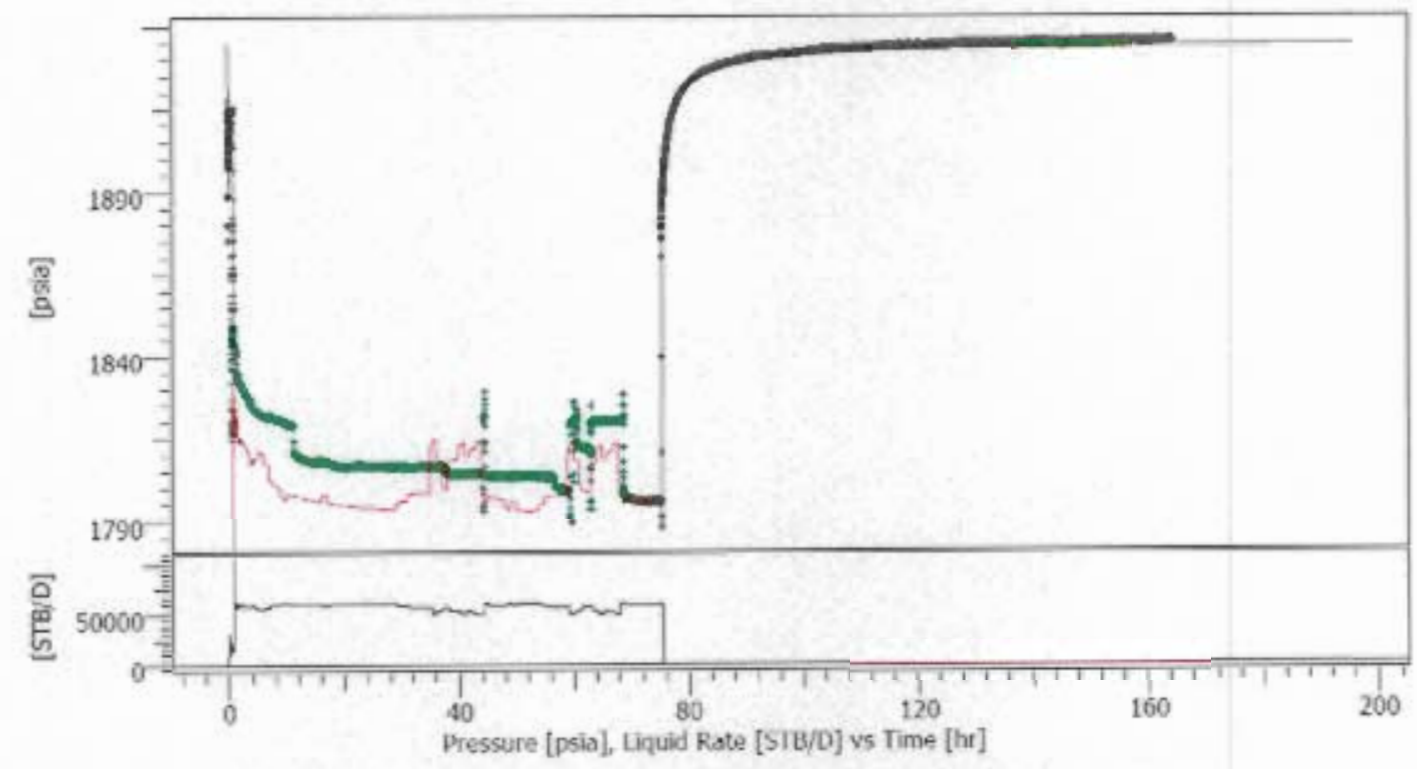

Figure 2 - Comparison of measured and finite conductivity analytic model results from buildup.

\section{RRG-4 Temperature Surveys}

Two temperature surveys where taken during the test program, the March $13^{\text {th }}$ survey before the start of the flow and the second survey on March 21 at the completion of the pressure buildup test. These two surveys are presented below in Figure 2. 


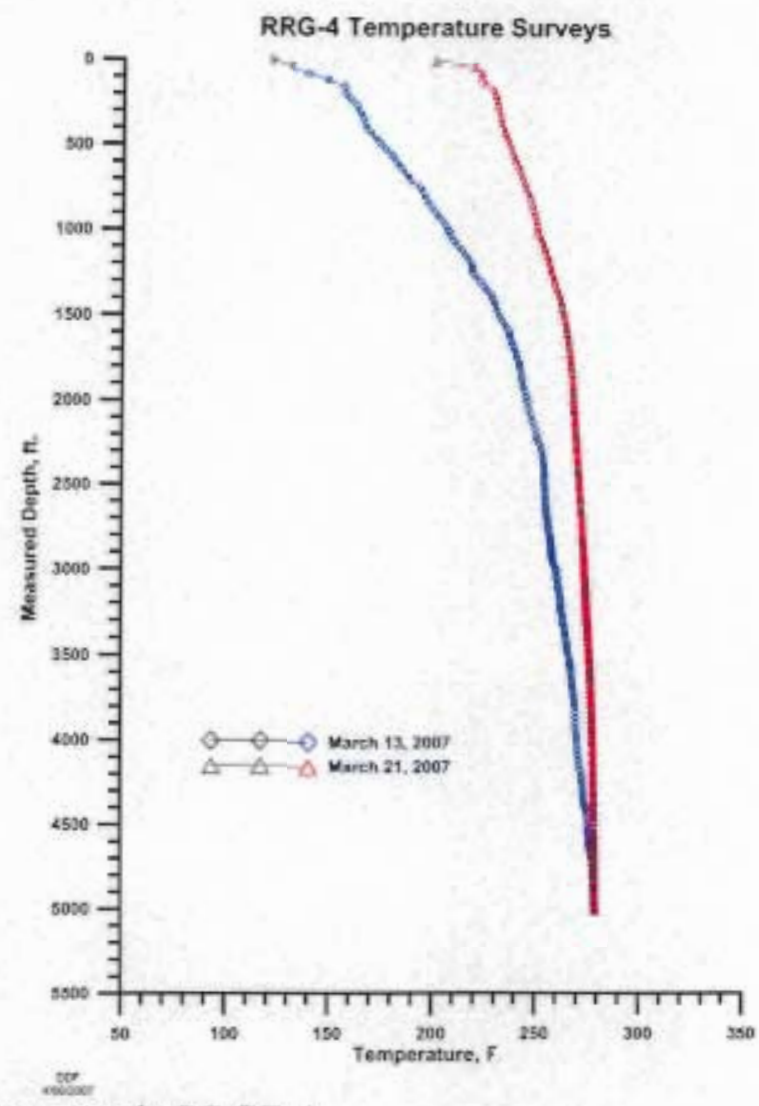

Figure 2 - Temperature surveys in RRGE-4.

The initial survey shows some character in profile and is generally correlative with the Salt Lake formation. The static surveys before and after the test with temperature converge at approximately 4700 feet, probably the primary feed in the Bridge fault zone. During the production test, the stabilized measured temperature was $\sim 278.0^{\circ} \mathrm{F}$, set at $2,850 \mathrm{ft} \mathrm{MD}$.

\section{Pressure Interference Results}

Pressure interference was measured in RRG-1, RRG-2, RRG-5, and RRG-11 in response to RRG-4, the active well. The estimate of interwell distances from the active well, RRG-4, is somewhat problematic due to the multiple legs in each well, the active portion of the reservoir exposed in the wellbore, and such. However, for this exercise, the interwell distances are estimated from a map view and the approximate centroid of the well legs. The observation pressures where measured for approximately 210 hours, Figure 3, with three wells clear showing pressure response to both the start and termination of production in RRG-4. In general, RRG-1, RRG-2, and RRG-5 showed clear and rapid response to the start and termination of production in RRG-4. This is consistent with all three wells completion in the Bridge fault zone, a high permeability and low storage structural feature. Pressure tool response in RRG-11 exhibited fairly rapid pressure response to the start of the flow test, but no response to the shut-in of RRG4 , raising questions as to tool reliability during the testing program. The pressure fall-off analysis is presented for completeness, however, the results are suspect.

The interference data was analyzed using a homogeneous or line source solution for flow in a radial system and a line source in a finite conductivity fractured media. Both solutions provide information on the interwell rescrvoir properties between the flowing well and the observation 
wells. The interference test results are consistent with RRG-4 sharing the same high permeability (structural) feature as RRG-1, RRG-2, and RRG-5 in the presence of a constant pressure boundary located several thousand of feet away. RRG-1, the closest well to RRG-4 exhibited clear and rapid response to rate changes in RRG-4 and had achieved almost full pressure recovery at the end of the 135 hour pressure buildup period suggesting closer proximity to a fault upflow zone than the other two wells.

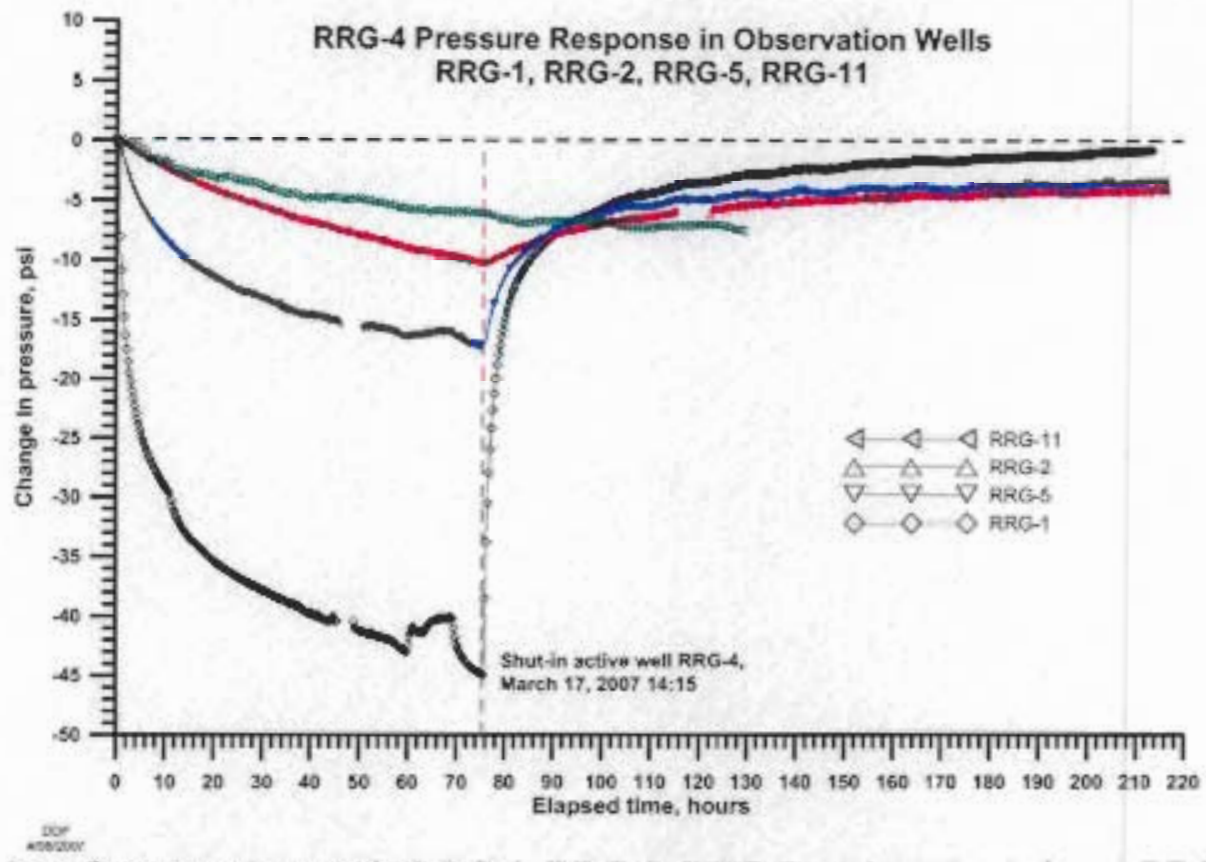

Figure 3 - Interference pressures in RRG-1, RRG-2, RRG-5, and RRG-11 due to RRG-4.

Table 1. Observation well interference pressure response to active well RRG-4.

\begin{tabular}{|l|r|r|r|r|r|r|}
\hline & $\begin{array}{c}\text { Estimated } \\
\text { distance to } \\
\text { RRG-4, ft }\end{array}$ & $\begin{array}{c}\text { Datum, } \\
\text { ft, MD }\end{array}$ & $\begin{array}{c}\text { Pressure } \\
\text { at datum, } \\
\text { psi }\end{array}$ & $\begin{array}{c}\text { First } \\
\text { interference } \\
\text { time, hours }\end{array}$ & $\begin{array}{c}\text { Maximum } \\
\text { pressure } \\
\text { change, psi }\end{array}$ & Comments \\
\hline RRG-1 & 1,570 & 3,450 & $1,567.442$ & 0.0639 & -44.92 & \\
\hline RRG-2 & 6,000 & 5,000 & $2,185.220$ & 1.652 & -10.64 & \\
\hline RRG-5 & 2,360 & 4,780 & $2,034.861$ & 0.4000 & -17.50 & \\
\hline RRG-11 & 6,000 & 0 & 51.675 & 0.3000 & -7.54 & $\begin{array}{l}\text { No response to } \\
\text { RRG-4 shut-in }\end{array}$ \\
\hline
\end{tabular}

Table 2. Interference pressure transient results.

\begin{tabular}{|l|r|r|r|r|r|}
\hline & \multicolumn{1}{|c|}{ RRG-1 } & \multicolumn{1}{c|}{ RRG-2 } & \multicolumn{1}{c|}{ RRG-5 } & \multicolumn{1}{|c|}{ RRG-11 } \\
\hline Homogeneous Flow Model & \multicolumn{4}{|c|}{ Pressure drawdown flow period } \\
\hline $\mathrm{p}_{\mathrm{i}, \mathrm{psi}}$ & 1567.51 & 2185.28 & 2034.86 & 51.675 \\
\hline $\mathrm{kh}, \mathrm{mD}-\mathrm{ft}$ & 133,960 & 202,190 & 201,680 & 102,700 \\
\hline$\phi \mathrm{h}, \mathrm{ft}$ & 2.82 & 21.7 & 25.1 & 51.4 \\
\hline $\mathrm{L}, \mathrm{ft}$ & $3.75 \mathrm{E}+5$ & 28,400 & 502,000 & 25,000 \\
\hline Boundary condition & $\begin{array}{r}\text { Constant } \\
\text { pressure }\end{array}$ & $\begin{array}{r}\text { Constant } \\
\text { pressure }\end{array}$ & $\begin{array}{r}\text { Constant } \\
\text { pressure }\end{array}$ & $\begin{array}{r}\text { Constant } \\
\text { pressure }\end{array}$ \\
\hline Two Porosity Slab Model & \multicolumn{5}{|c|}{ Pressure drawdown flow period } \\
\hline kh & 120,600 & 136,070 & 183,990 & 98,060 \\
\hline
\end{tabular}




\begin{tabular}{|c|c|c|c|c|}
\hline$\phi h, f t$ & 10.8 & 29.4 & 29.1 & 221 \\
\hline Lambda & 0.00217 & $2.55 \mathrm{E}-8$ & $1.84 \mathrm{E}-4$ & $1.33 \mathrm{E}-14$ \\
\hline Omega & 0.00447 & 0.0477 & 0.689 & 0.196 \\
\hline $\mathrm{L}, \mathrm{ft}$ & 995,000 & 94,700 & 281,000 & 35,200 \\
\hline Homogeneous Flow Model & \multicolumn{4}{|c|}{ Pressure buildup flow period } \\
\hline $\mathrm{p}_{\mathrm{i}}, \mathrm{psi}$ & 1563.9 & 2184.12 & 2031.2 & $\mathrm{n} / \mathrm{a}$ \\
\hline $\mathrm{kh}, \mathrm{mD}-\mathrm{ft}$ & 296,760 & 373,240 & 140,510 & $\mathrm{n} / \mathrm{a}$ \\
\hline$\phi \mathrm{h}, \mathrm{ft}$ & 3.79 & 28.4 & 31.8 & $\mathrm{n} / \mathrm{a}$ \\
\hline $\mathrm{L}, \mathrm{ft}$ & 183 & 5000 & 3650 & $\mathrm{n} / \mathrm{a}$ \\
\hline Boundary condition & $\begin{array}{l}\text { Constant } \\
\text { pressure }\end{array}$ & No flow & $\begin{array}{c}\text { Constant } \\
\text { pressure }\end{array}$ & $\begin{array}{l}\text { Constant } \\
\text { pressure }\end{array}$ \\
\hline Two Porosity Slab Model & \multicolumn{4}{|c|}{ Pressure buildup flow period } \\
\hline $\mathrm{kh}$ & 64,550 & 136,070 & 161,640 & $\mathrm{n} / \mathrm{a}$ \\
\hline$\phi h, f t$ & 5.74 & 31.3 & 31.6 & $\mathrm{n} / \mathrm{a}$ \\
\hline Lambda & $3.68 \mathrm{E}-5$ & $2.55 \mathrm{E}-8$ & $5.4 \mathrm{E}-5$ & $\mathrm{n} / \mathrm{a}$ \\
\hline Omega & 0.00171 & 0.0477 & 0.0392 & $\mathrm{n} / \mathrm{a}$ \\
\hline $\mathrm{L}, \mathrm{ft}$ & 3,750 & 94,700 & 4,540 & $\mathrm{n} / \mathrm{a}$ \\
\hline
\end{tabular}

The Saphir plots and analysis are attached in Appendix A.

\section{Discussion of Test Results}

The interference results for RRG- 11 are presented for completeness, though there is concern the pressure tool had drift and was not responding to the pressure transient. The interference results will address only wells RRG-1, RRG-2, and RRG-5. These three wells are completed in the Bridge fault zone show fault conductivities of ranging from 64,000 to 184,000 md- $\mathrm{ft}$. The interference storage indicates fault porosity of 1 to $3 \%$ consistent with fault porosities. RRG-1, RRG-2, and RRG-5 all used a constant pressure boundary from 3700 to $4500 \mathrm{ft}$ distant with the finite conductivity analysis. 


\section{Temperature Surveys of Observation Wells}
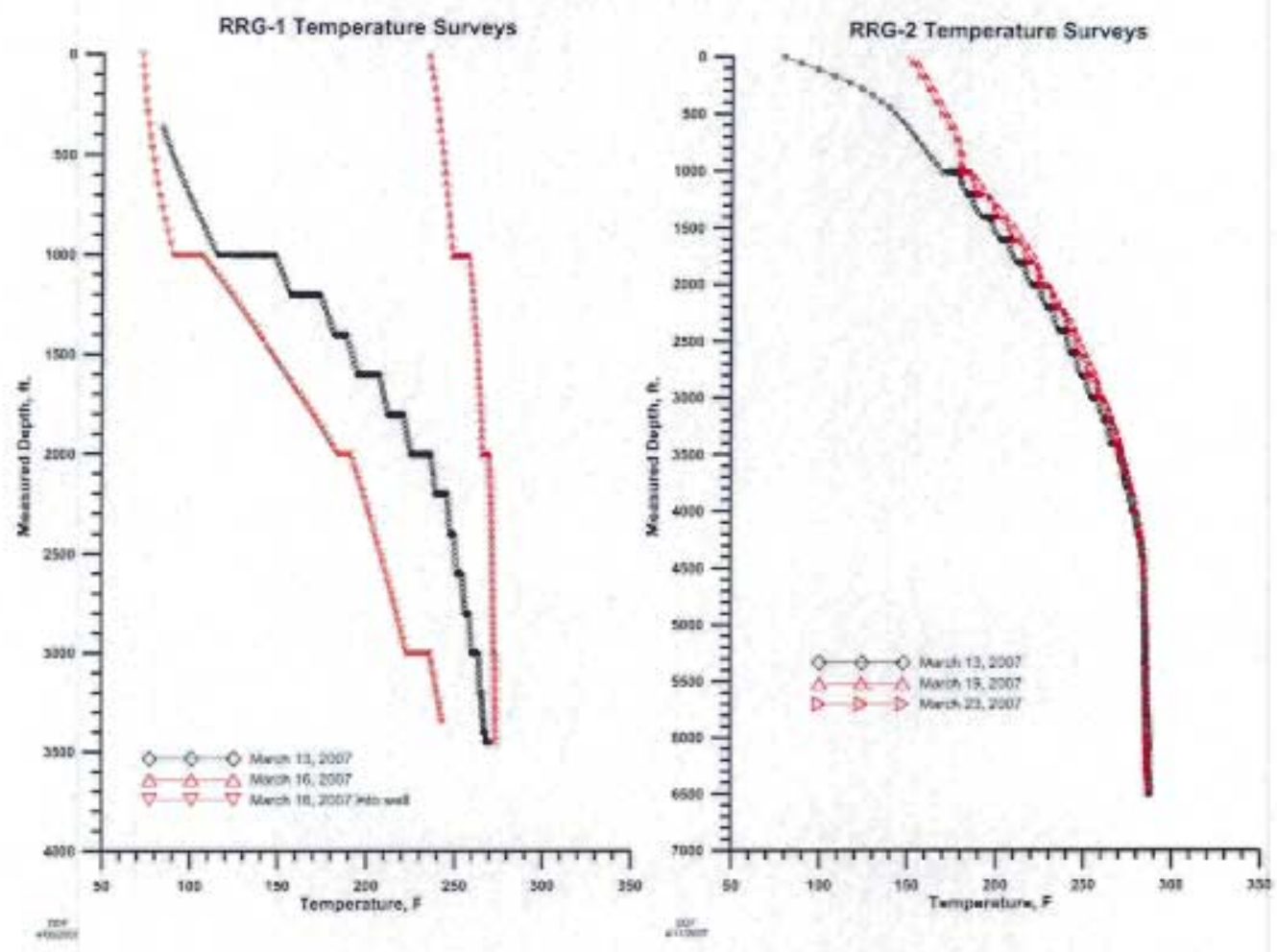

Figure 4-RRG-1 temperature surveys.

Figure 5-RRG-2 temperature surveys.

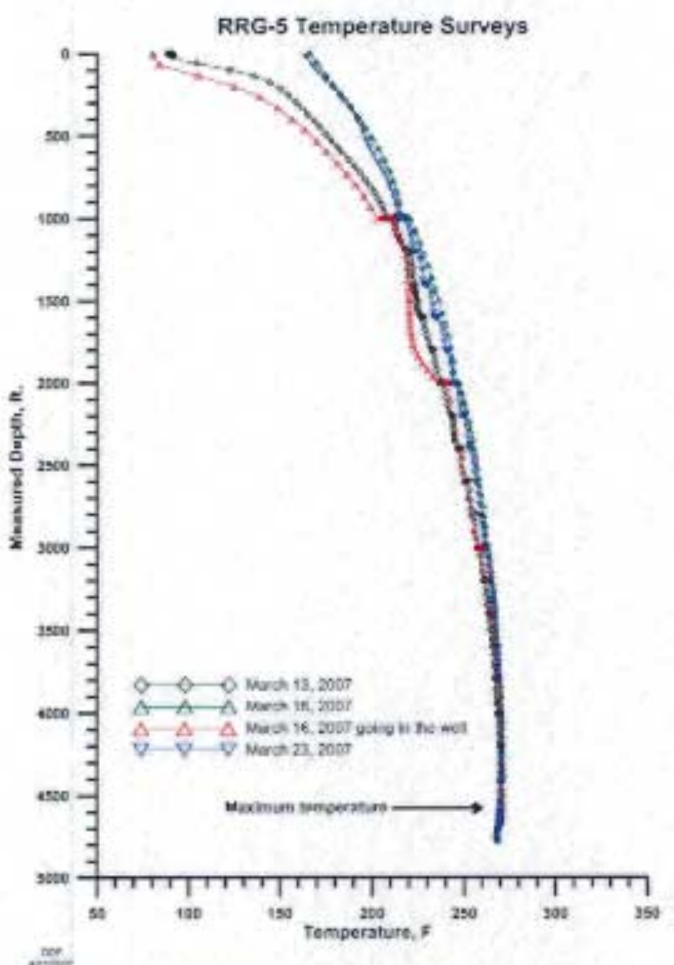

Figure 6-RRG-5 temperature surveys. 


\section{Discussion of Observation Well Temperature Surveys}

The temperature survey of RRG-1 is rather blocky, as the tool had some temperature lag. The tool stops during surveying the well are very noticeable. The surveys exhibit very poor repeatability. The temperature survey of RRG-2 has much better tool response but some temperature drift during the March $13^{\text {th }}$ survey. Below $4,000 \mathrm{ft} \mathrm{MD}$ there is very good agreement between the three temperature surveys. RRG-5 temperature surveys are in very good agreement with the March 16 survey going into the well exhibiting some anomalous behavior from about 1,200 to $2,000 \mathrm{ft} \mathrm{MD}$.

D.D. Faulder, P.E.

SAIC

April 11, 2007 
Appendix A - Saphir

RRG-4 pressure transient results

Interference results for:

RRG-1

RRG-2

RRG-5

RRG-11 


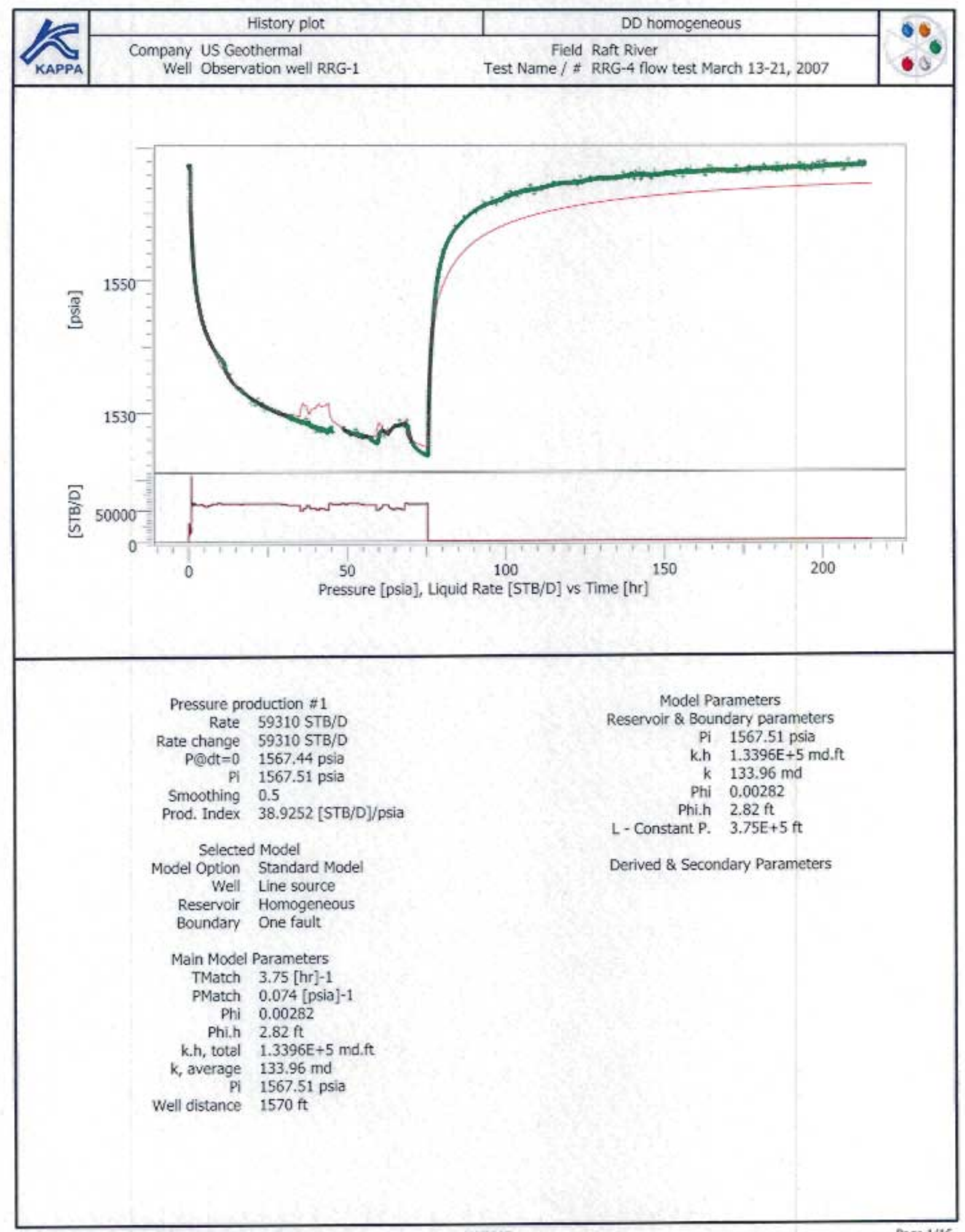




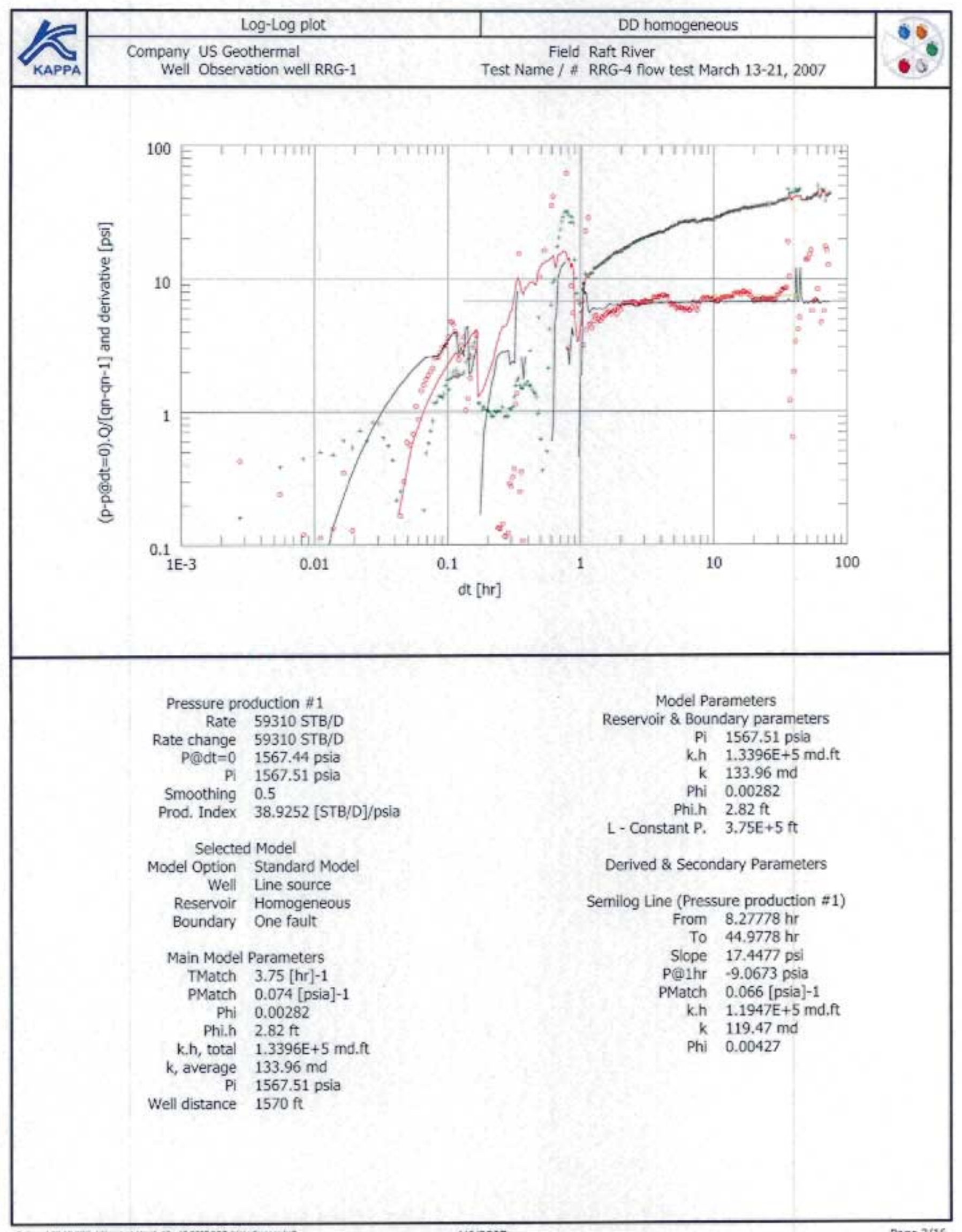

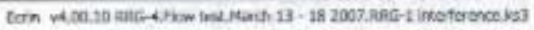




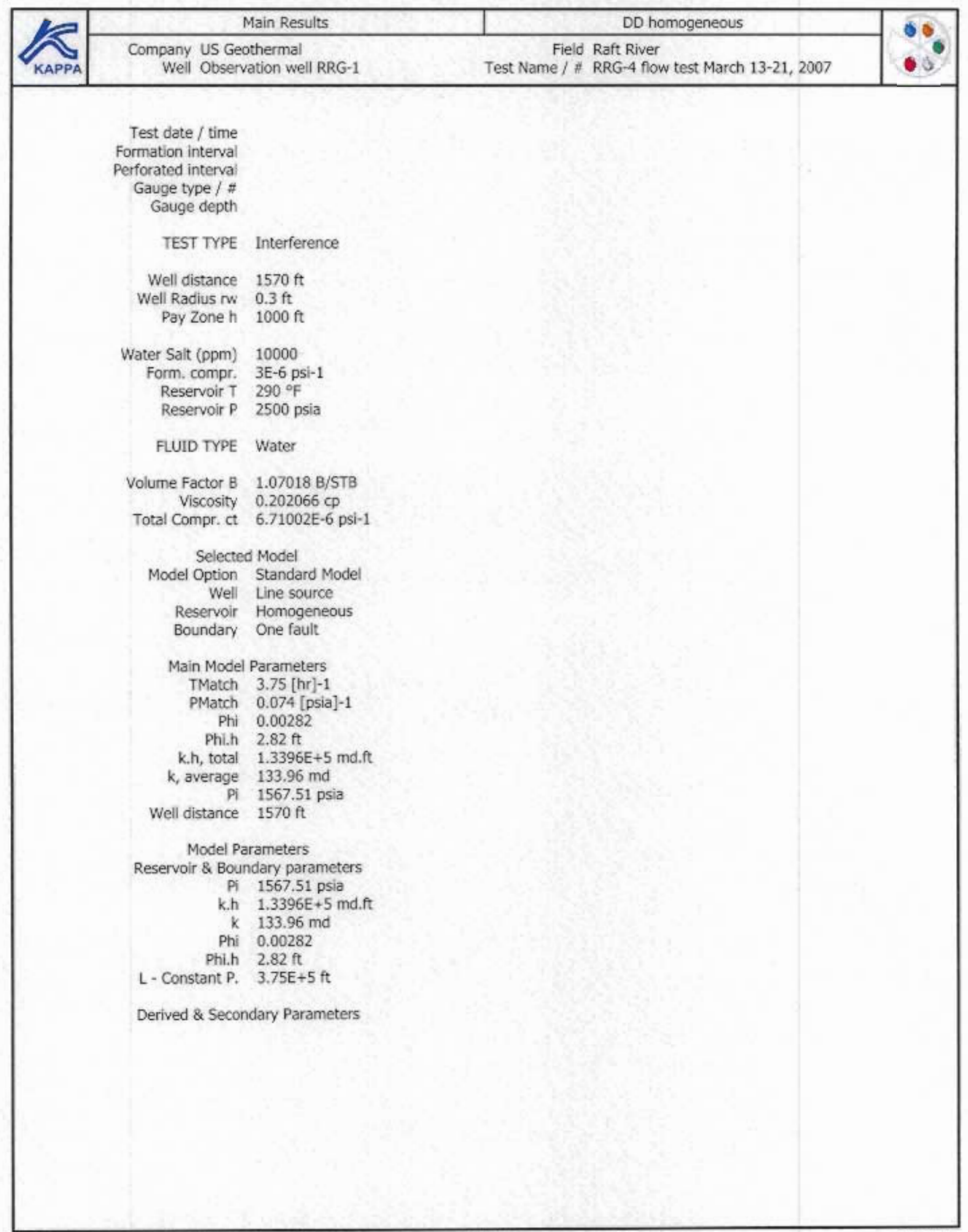




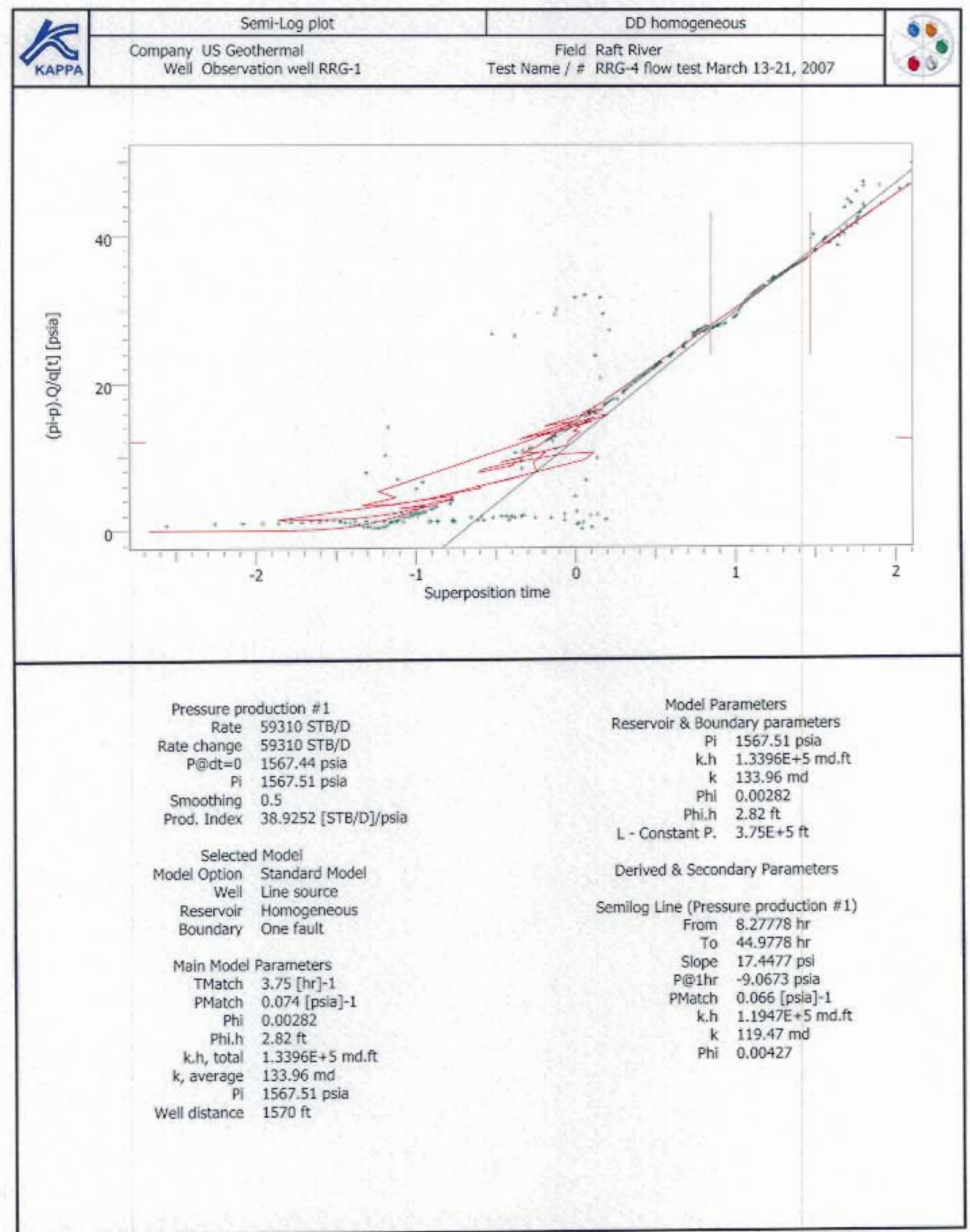




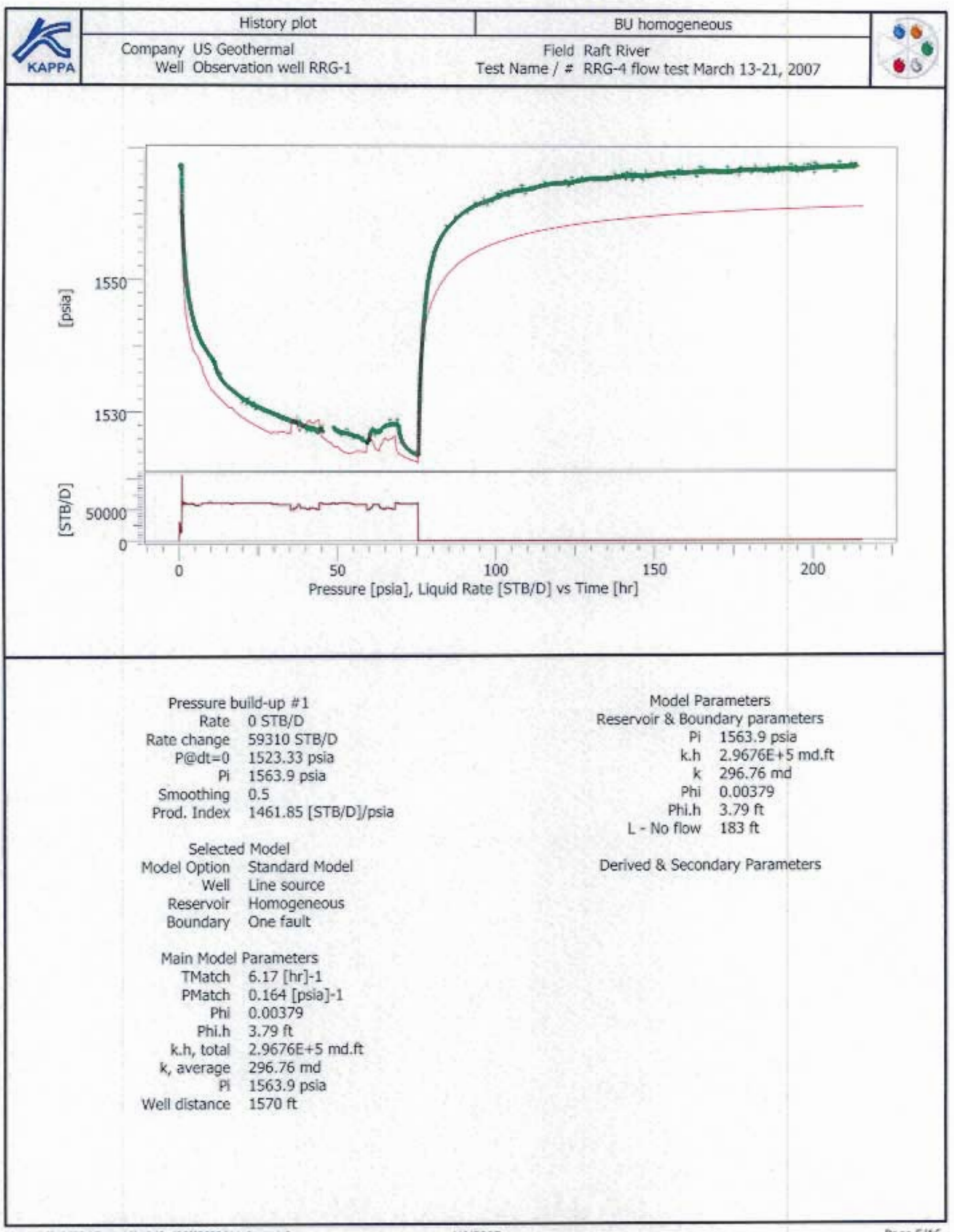




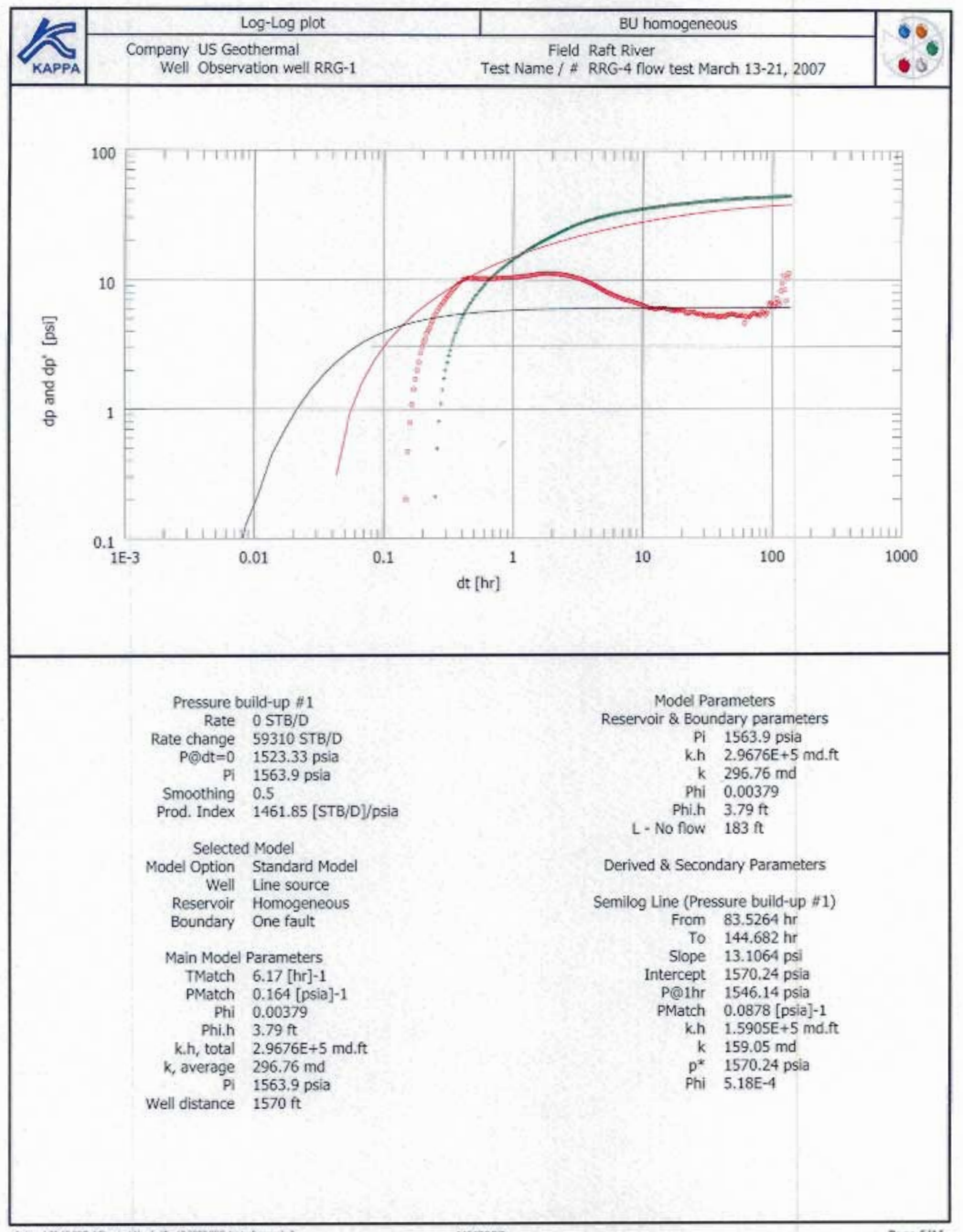




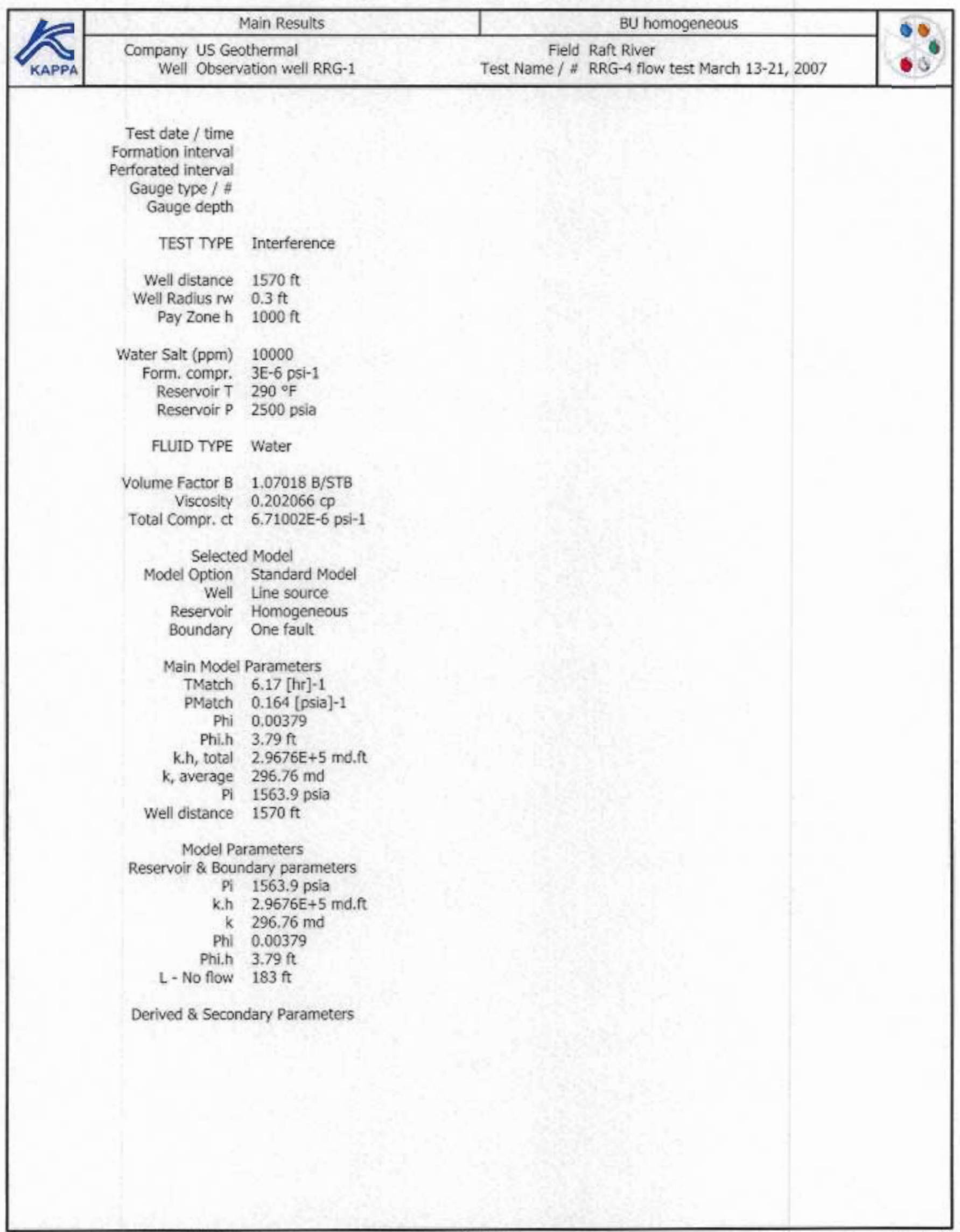




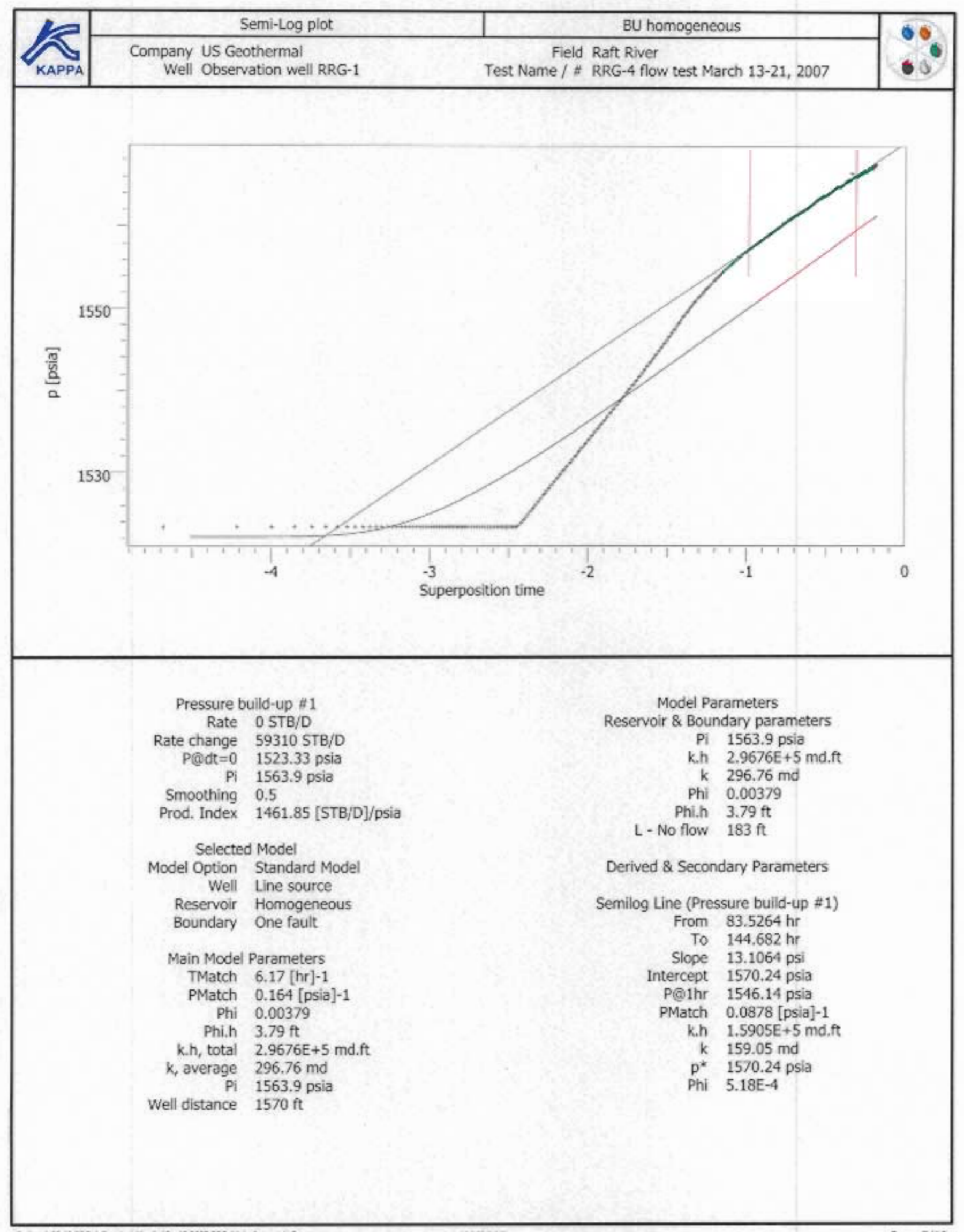




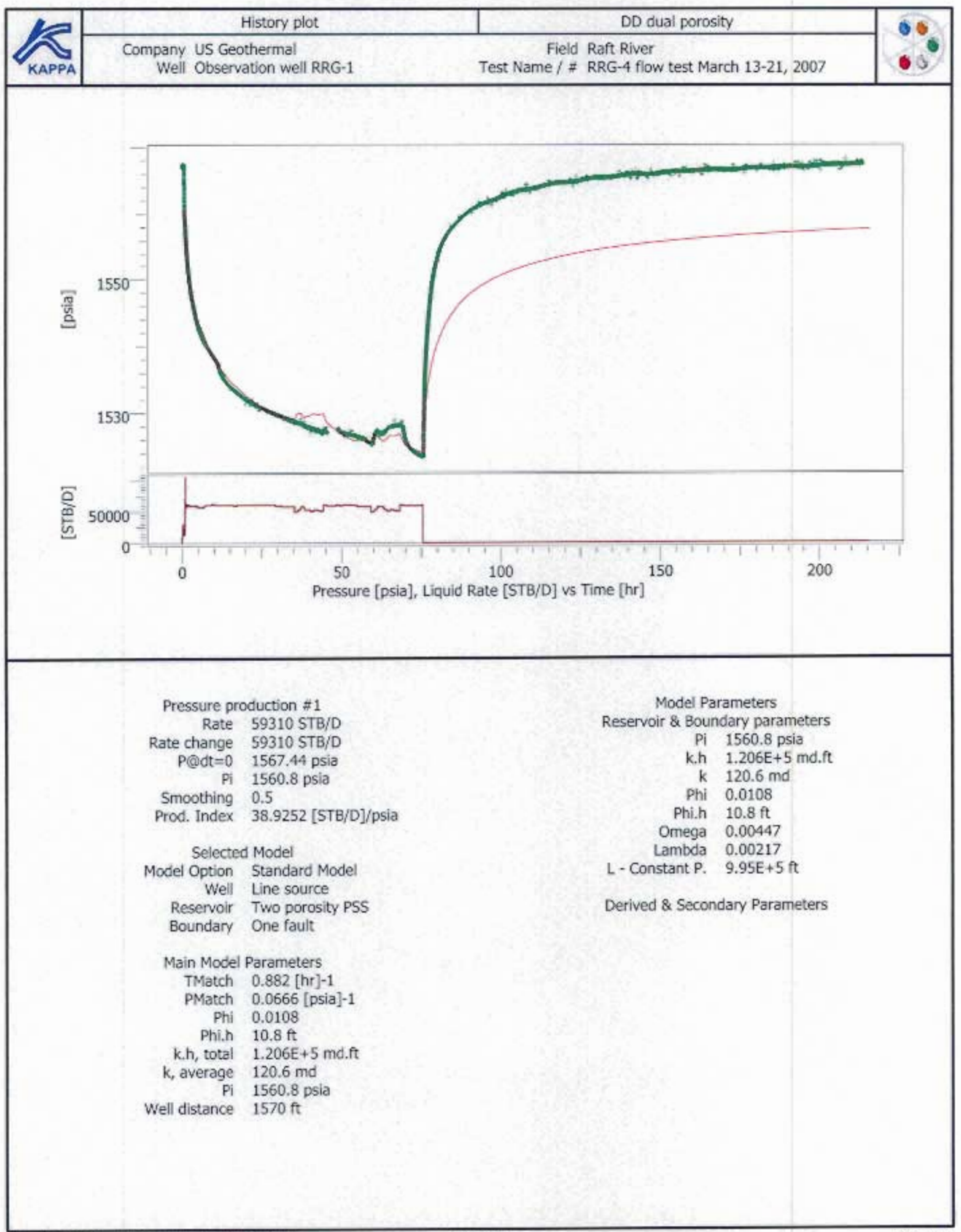




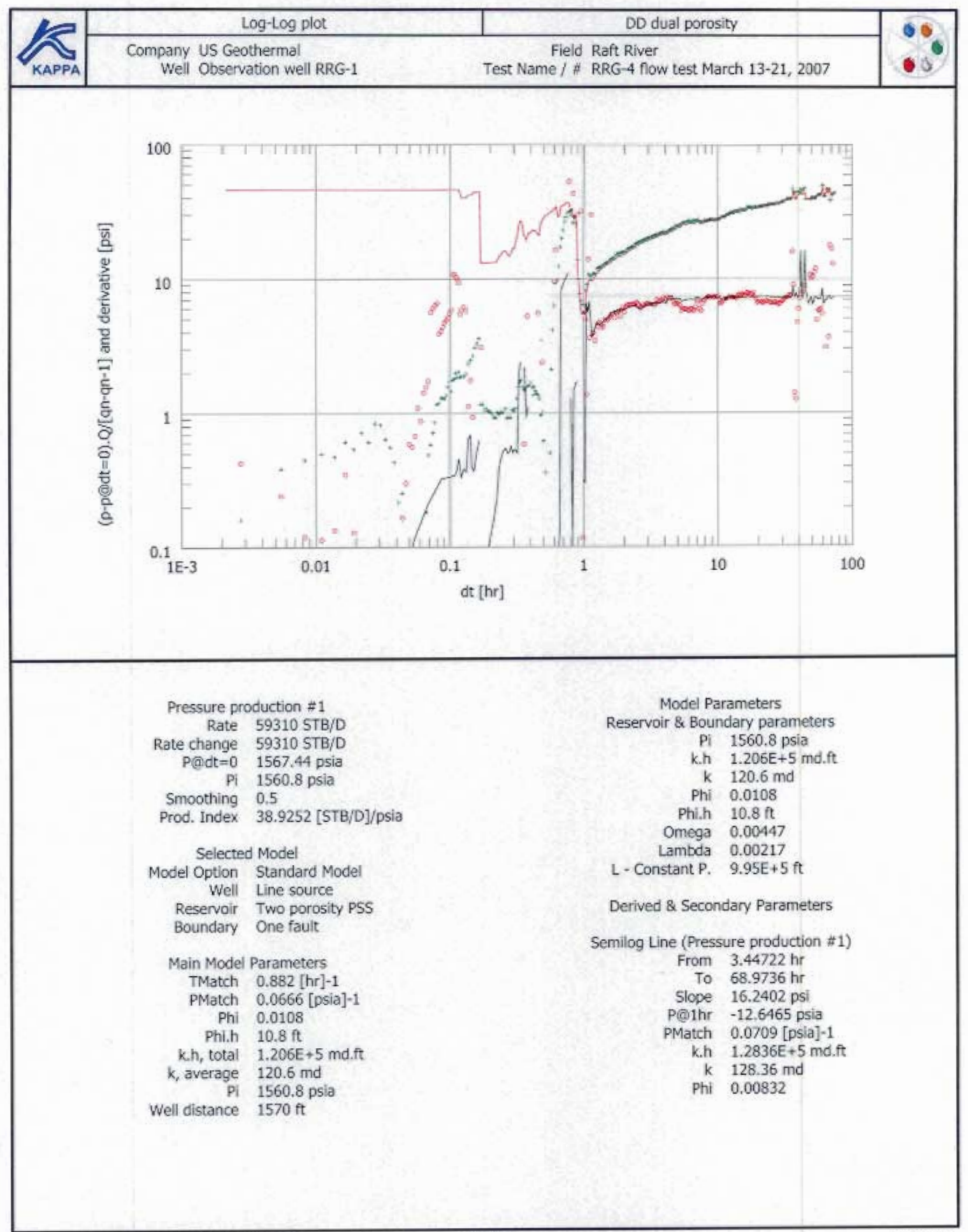




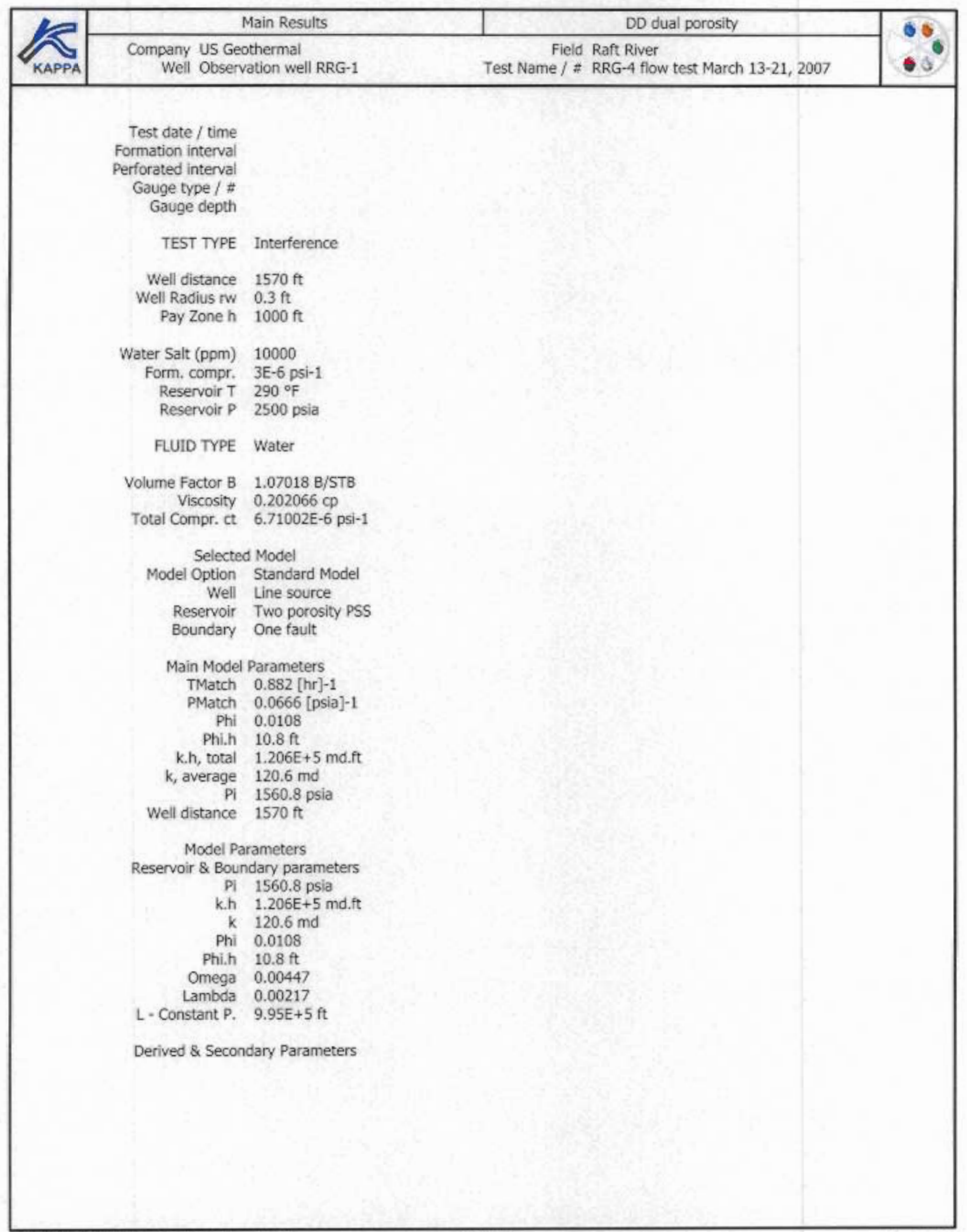




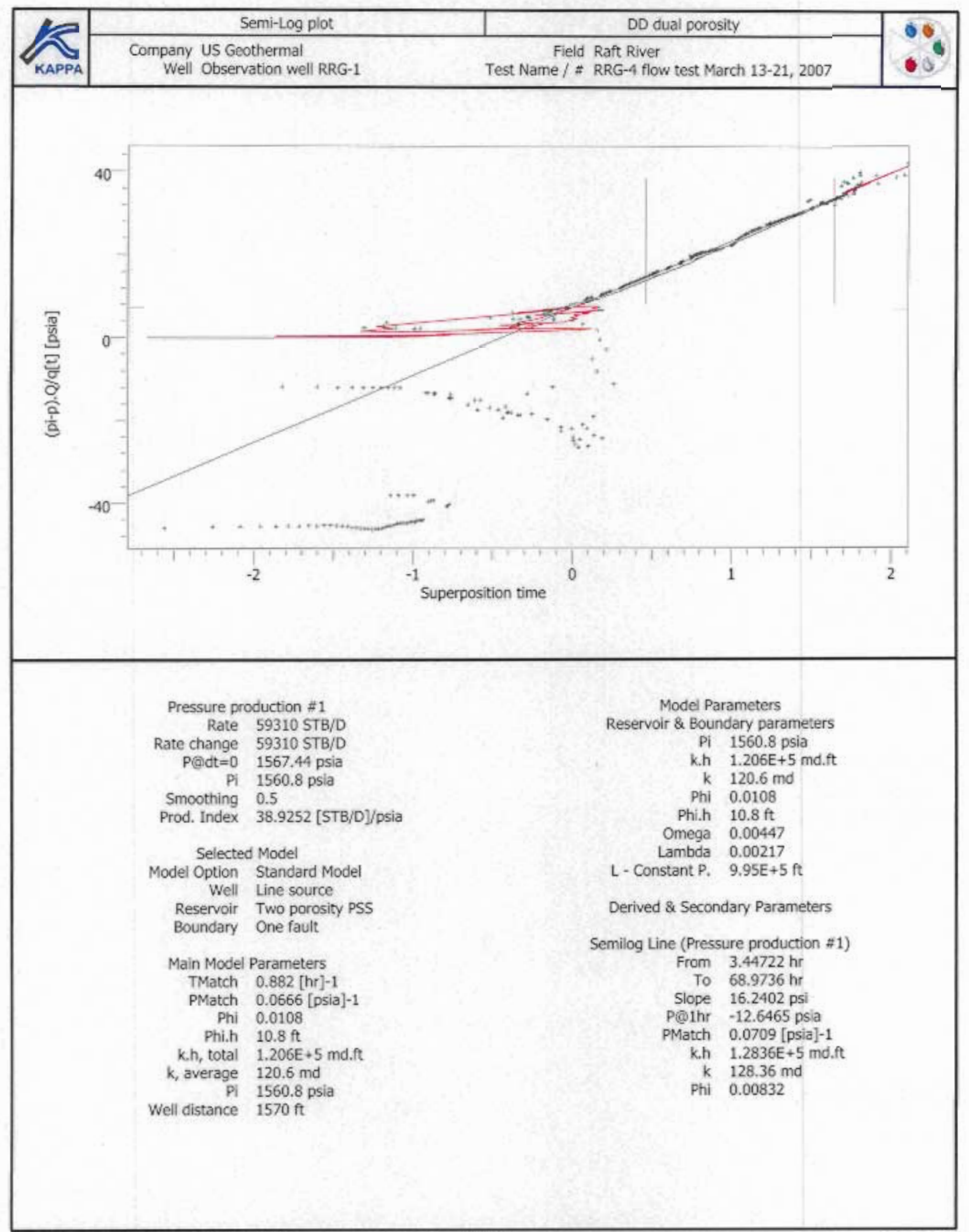




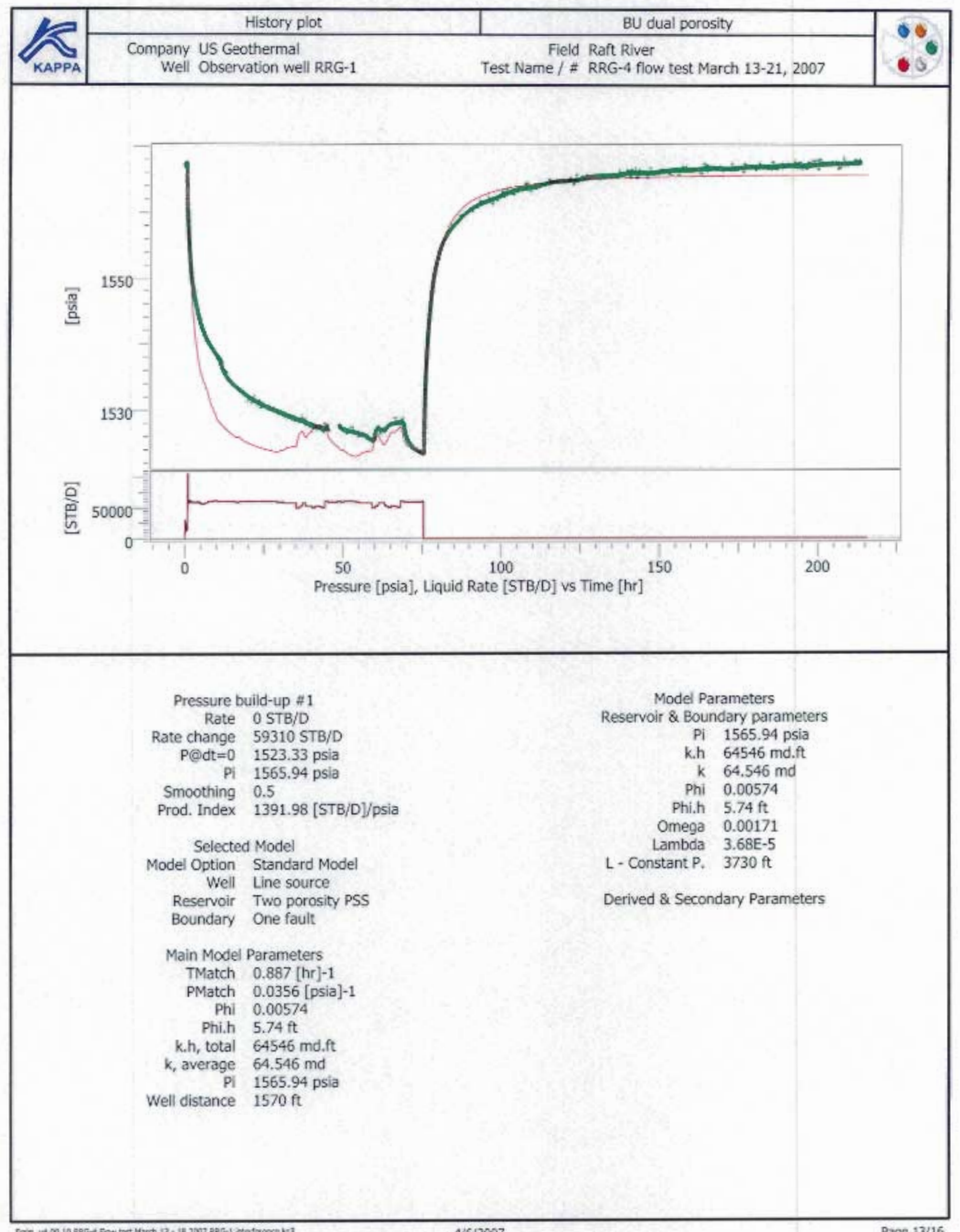




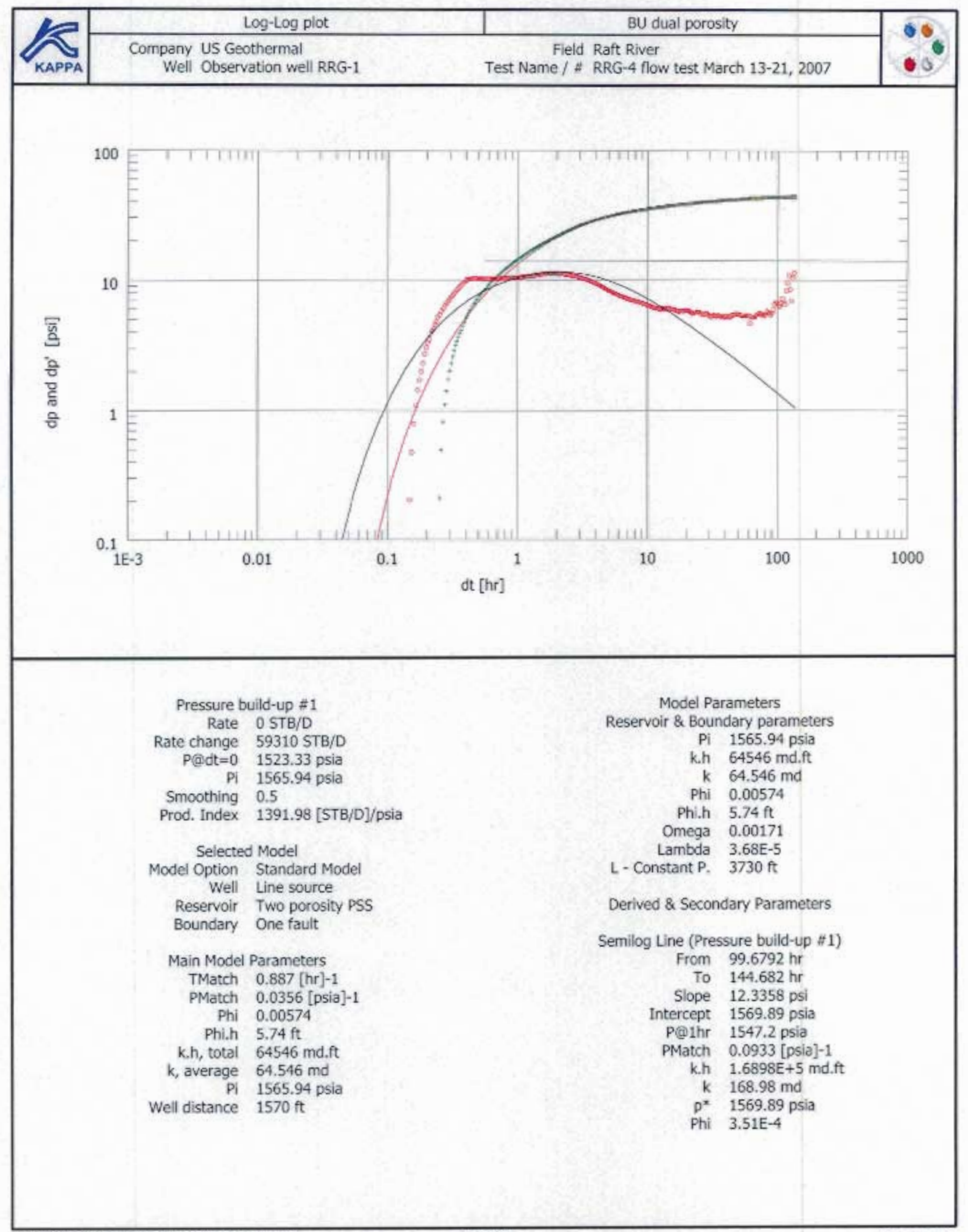




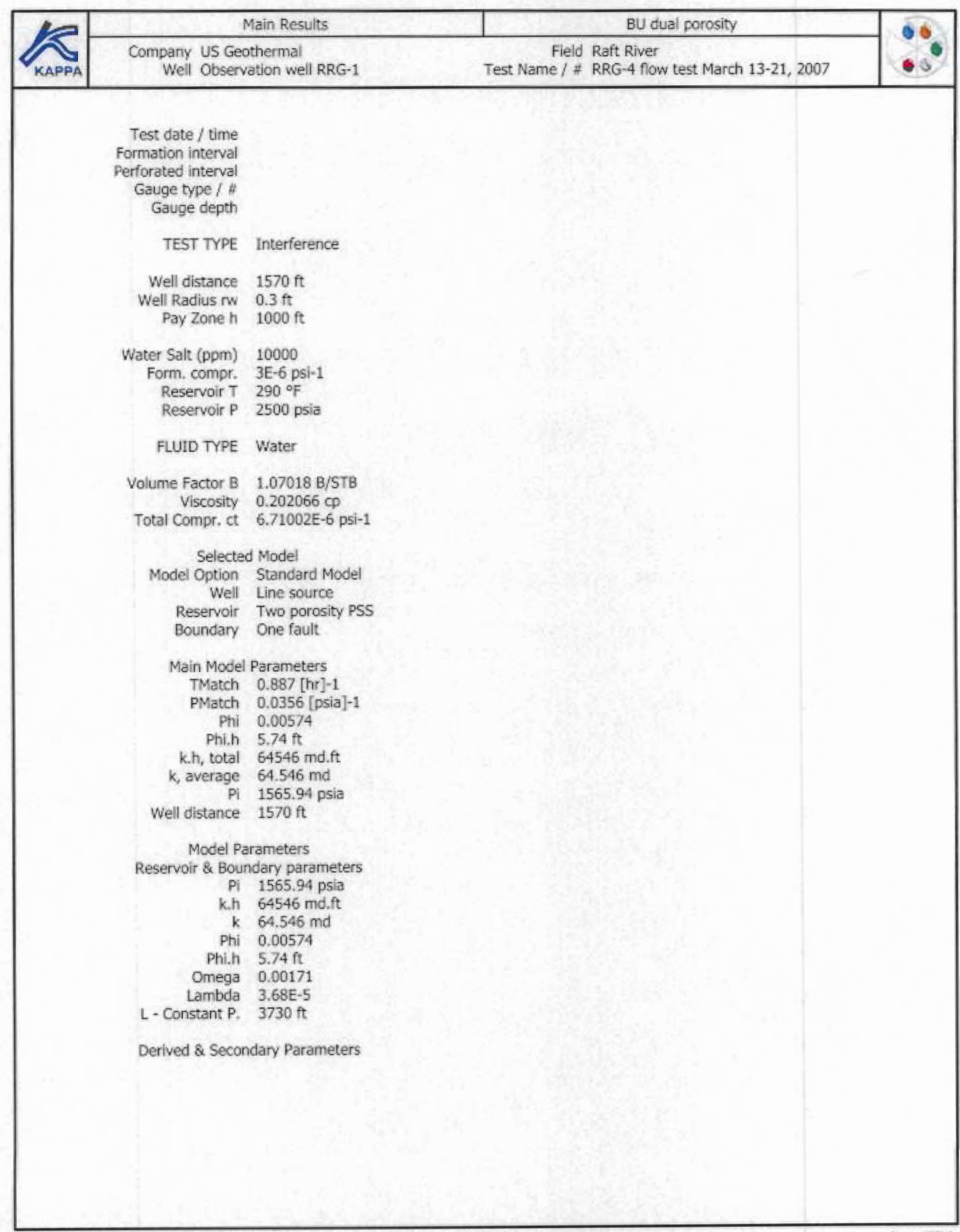




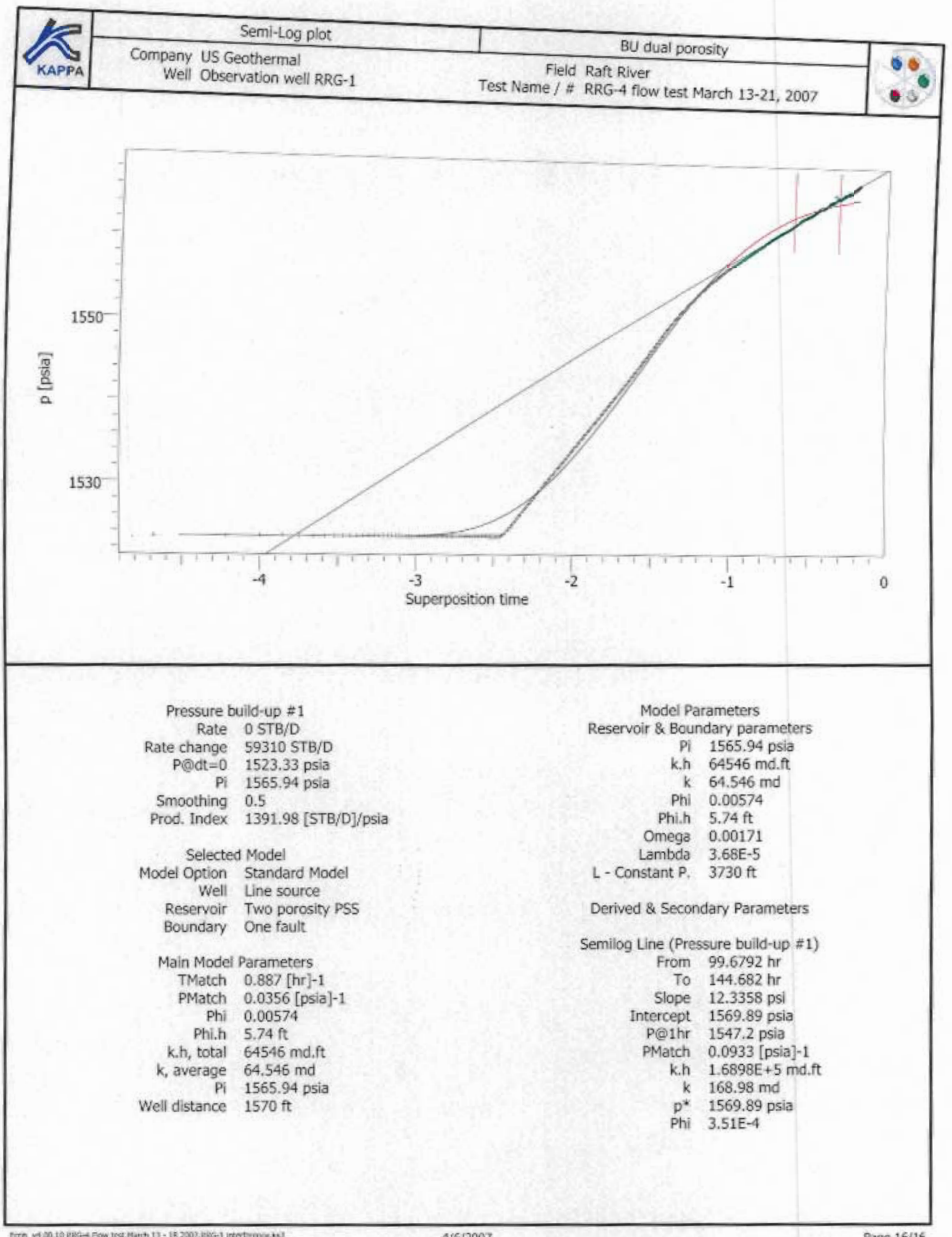




\begin{tabular}{|c|c|c|}
\hline \multicolumn{2}{|c|}{ History plot } & DD homogeneous \\
\cline { 2 - 4 } & $\begin{array}{c}\text { Company US Geothermal } \\
\text { Well Observation well RRG-2 }\end{array}$ & Test Name / \# RRG River flow test \\
\hline
\end{tabular}

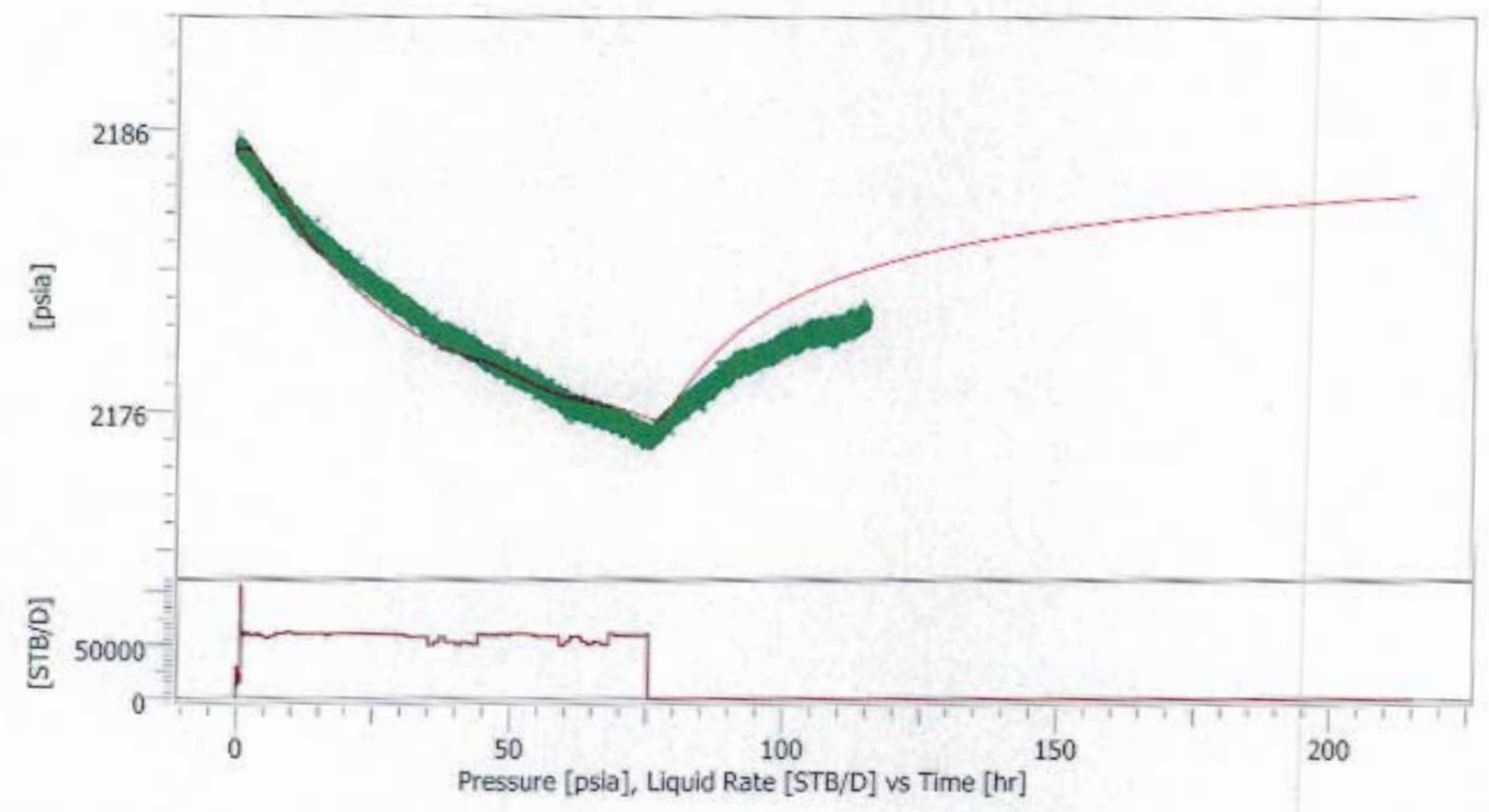

Pressure production $\# 1$

$\begin{aligned} & \text { Rate } 59310 \text { STB/D } \\ & \text { Rate change } 59310 \text { STB/D } \\ & \text { P@dt=0 } 2185.28 \text { psia } \\ & \text { Pi } 2185.28 \text { psia } \\ & \text { Smoothing } 1 \\ & \text { Prod. Index } 27.2636 \text { [STB/D]/psia } \\ & \text { Selected Model } \\ & \text { Model Option Standard Model } \\ & \text { Well Line source } \\ & \text { Reservoir Homogeneous } \\ & \text { Boundary } \text { One fault } \\ & \text { Main Model Parameters } \\ & \text { TMatch } 0.0502 \text { [hr]-1 } \\ & \text { PMatch } 0.112 \text { [psia]-1 } \\ & \text { Phi } 0.0217 \\ & \text { Phi.h } 21.7 \mathrm{ft} \\ & \text { k.h, total } 2.0219 \mathrm{E}+5 \mathrm{md} . \mathrm{ft} \\ & \text { k, average } 202.19 \text { md } \\ & \text { Pi } 2185.28 \mathrm{psia} \\ & \text { Well distance } 6000 \mathrm{ft}\end{aligned}$

Model Parameters Reservoir \& Boundary parameters

$$
\begin{array}{rl}
\text { Pi } & 2185.28 \text { psia } \\
k . h & 2.0219 \mathrm{E}+5 \text { md.ft } \\
k & 202.19 \text { md } \\
\text { Phi } & 0.0217 \\
\text { Phi.h } & 21.7 \mathrm{ft}
\end{array}
$$

L - Constant P. $\quad 28400 \mathrm{ft}$

Derived \& Secondary Parameters 


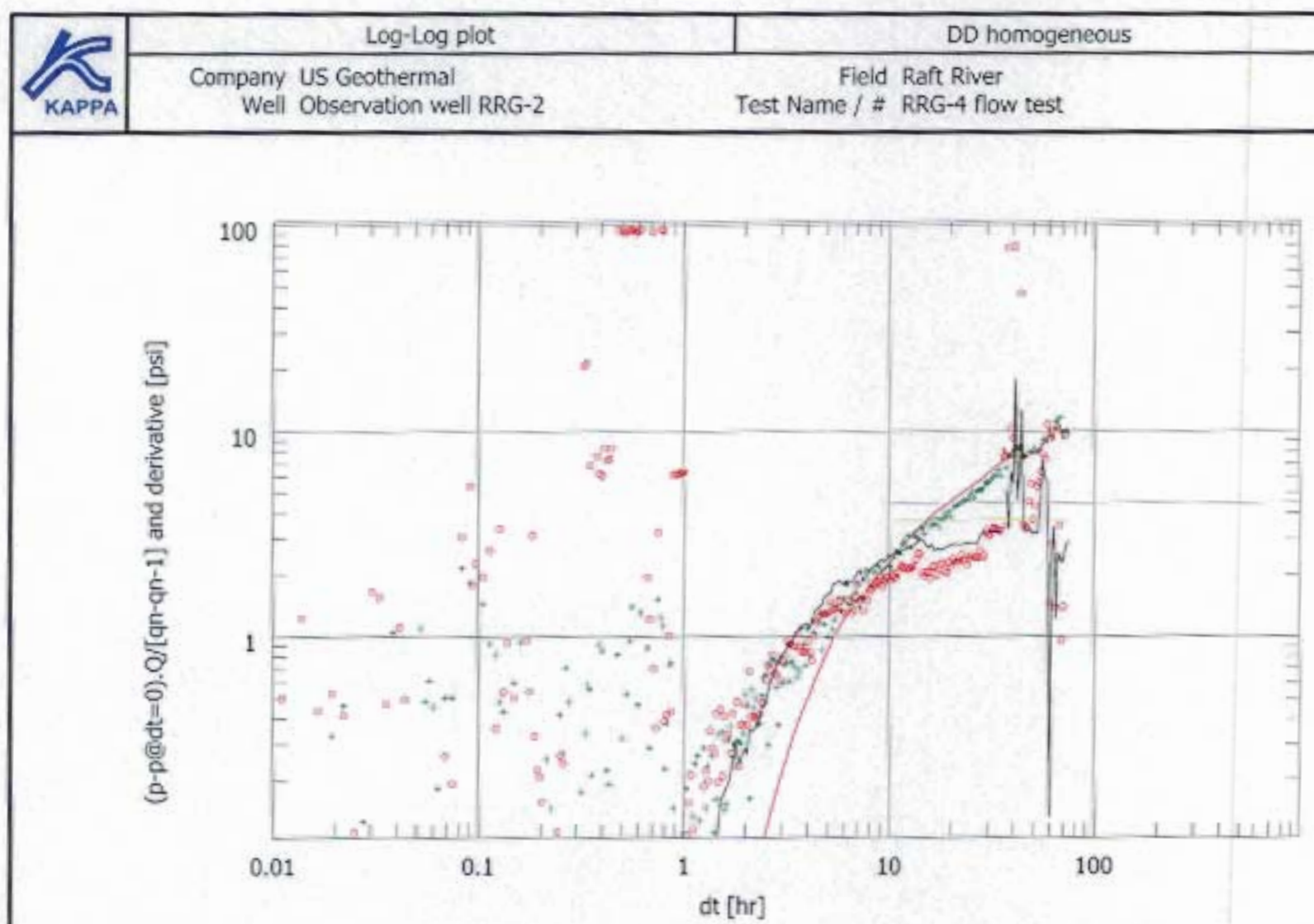

Pressure production \#1

$\begin{aligned} \text { Rate } & 59310 \text { STB/D } \\ \text { Rate change } & 59310 \text { STB/D } \\ \text { P@dt=0 } & 2185.28 \text { psia } \\ \text { Pi } & 2185.28 \text { psia } \\ \text { Smoothing } & 1 \\ \text { Prod. Index } & 27.2636[\text { STB/D } / \text { psia }\end{aligned}$

Selected Model

Model Option Standard Model

Well Line source

Reservoir Homogeneous

Boundary One fault

Main Model Parameters

TMatch $0.0502[\mathrm{hr}]-1$

PMatch 0.112 [psia]-1

Phi 0.0217

Phi.h $21.7 \mathrm{ft}$

k.h, total $2.0219 E+5 \mathrm{md} . \mathrm{ft}$

$k$, average 202.19 md

Pi 2185.28 psia

Well distance $6000 \mathrm{ft}$
Model Parameters

Reservoir \& Boundary parameters

$$
\begin{array}{rl}
\text { Pi } & 2185.28 \text { psia } \\
k . h & 2.0219 E+5 \text { md.ft } \\
k & 202.19 \text { md } \\
\text { Phi } & 0.0217
\end{array}
$$

Phi.h $21.7 \mathrm{ft}$

L - Constant P. $28400 \mathrm{ft}$

Derived \& Secondary Parameters

Semilog Line (Pressure production \#1)

$$
\begin{array}{rl}
\text { From } & 10.4111 \mathrm{hr} \\
\text { To } & 74.3222 \mathrm{hr} \\
\text { Slope } & 8.47124 \mathrm{psi} \\
\text { P(9) 1hr } & -16.8222 \mathrm{psia} \\
\text { PMatch } & 0.136 \text { [psia] }-1 \\
\text { k.h } & 2.4607 \mathrm{E}+5 \text { md.ft } \\
k & 246.07 \text { md } \\
\text { Phi } & 0.0176
\end{array}
$$




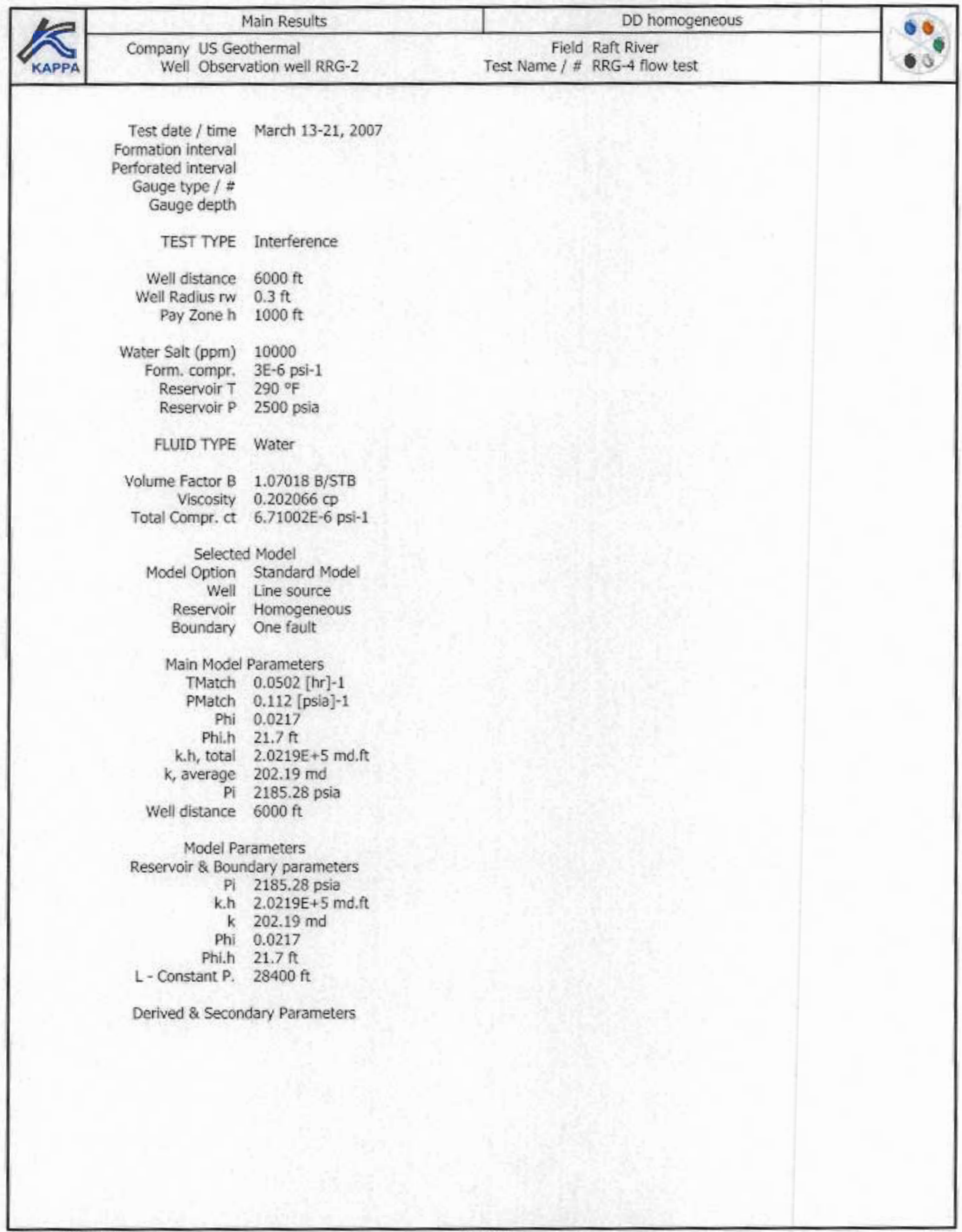




\begin{tabular}{|c|c|c|}
\hline \multirow{2}{*}{\begin{tabular}{|c|c|} 
Semi-Log plot \\
\cline { 2 - 3 }
\end{tabular}} & $\begin{array}{c}\text { Company US Geothermal } \\
\text { Well Observation well RRG-2 }\end{array}$ & Field Raft River \\
\hline
\end{tabular}

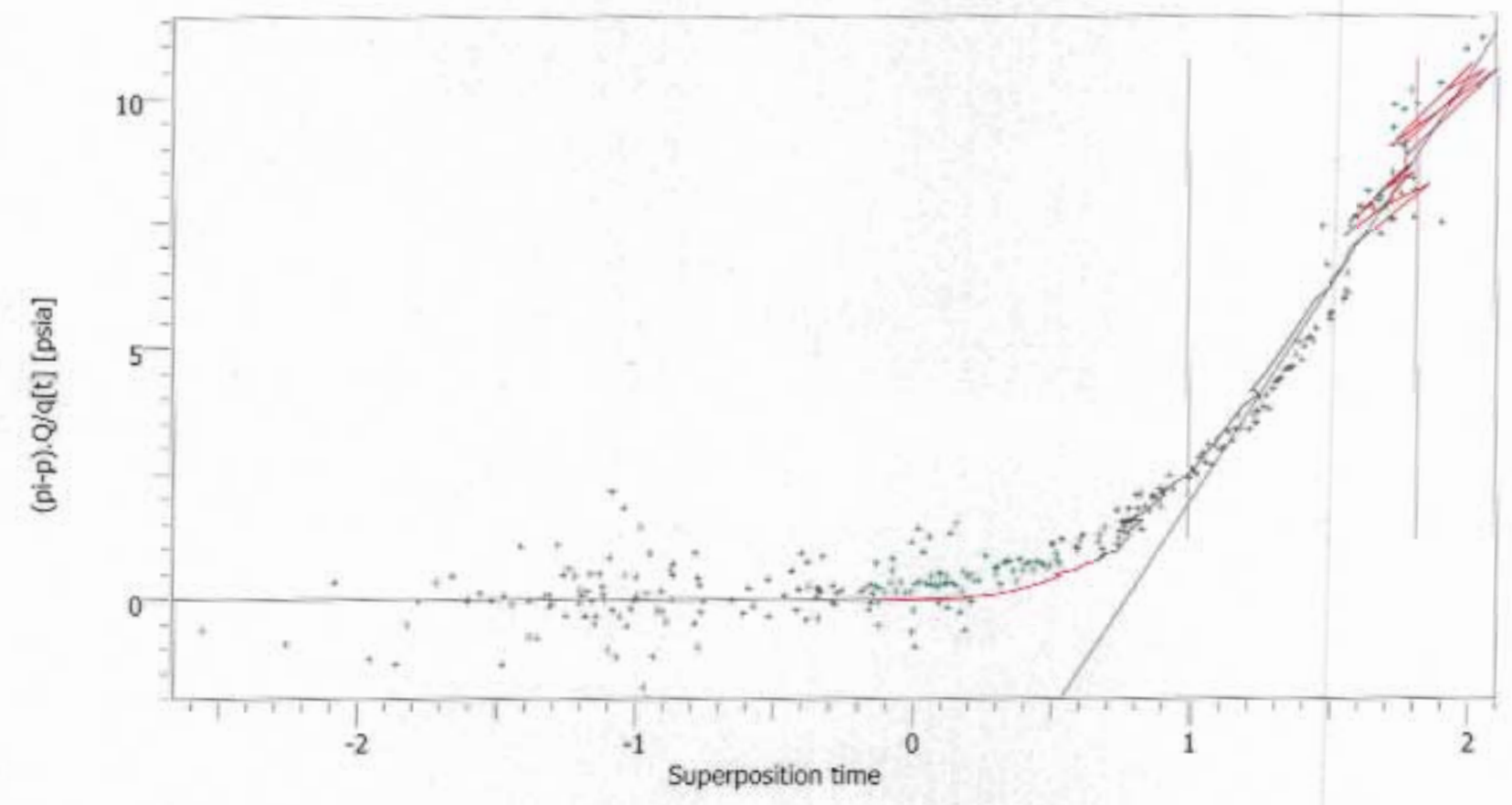

Pressure production \#1

$\begin{aligned} & \text { Rate } 59310 \mathrm{STB} / \mathrm{D} \\ & \text { Rate change } 59310 \mathrm{STB} / \mathrm{D} \\ & \text { P@dt=0 } 2185.28 \text { psia } \\ & \text { Pi } 2185.28 \mathrm{psia} \\ & \text { Smoothing } 1 \\ & \text { Prod. Index } 27.2636 \text { [5TB/D]/psia } \\ & \text { Selected Model } \\ & \text { Model Option } \text { Standard Model } \\ & \text { Well } \text { Line source } \\ & \text { Reservoir } \text { Homogeneous } \\ & \text { Boundary } \text { One fault } \\ & \text { Main Model Parameters } \\ & \text { TMatch } 0.0502 \text { [hr]-1 } \\ & \text { PMatch } 0.112 \text { [psia]-1 } \\ & \text { Phi } 0.0217 \\ & \text { Phi.h } 21.7 \mathrm{ft} \\ & \text { k.h, total } 2.0219 \mathrm{E}+5 \mathrm{md} . \mathrm{ft} \\ & \text { k, average } 202.19 \text { md } \\ & \text { Pi } 2185.28 \text { psia } \\ & \text { Well distance } 6000 \mathrm{ft}\end{aligned}$

Model Parameters Reservoir \& Boundary parameters

$$
\begin{array}{rl}
\text { Pi } & 2185.28 \text { psia } \\
k . h & 2.0219 E+5 \text { md.ft } \\
k & 202.19 \text { md } \\
\text { Phi } & 0.0217 \\
\text { Phi.h } & 21.7 \mathrm{ft}
\end{array}
$$

L - Constant P. $\quad 28400 \mathrm{ft}$

Derived \& Secondary Parameters

Semilog Line (Pressure production \#1)

$$
\begin{aligned}
\text { From } & 10.4111 \mathrm{hr} \\
\text { To } & 74.3222 \mathrm{hr} \\
\text { Slope } & 8.47124 \mathrm{psi} \\
\text { P@1hr } & -16.8222 \text { psia } \\
\text { PMatch } & 0.136 \text { [psia] }-1 \\
\text { k.h } & 2.4607 \mathrm{E}+5 \mathrm{md} . \mathrm{ft} \\
\text { k } & 246.07 \mathrm{md} \\
\text { Phi } & 0.0176
\end{aligned}
$$




\begin{tabular}{|c|c|c|}
\hline & History plot & DD dual porosity \\
\cline { 2 - 4 } & $\begin{array}{c}\text { Company US Geothermal } \\
\text { Well Observation well RRG-2 }\end{array}$ & Field Raft River \\
\hline
\end{tabular}

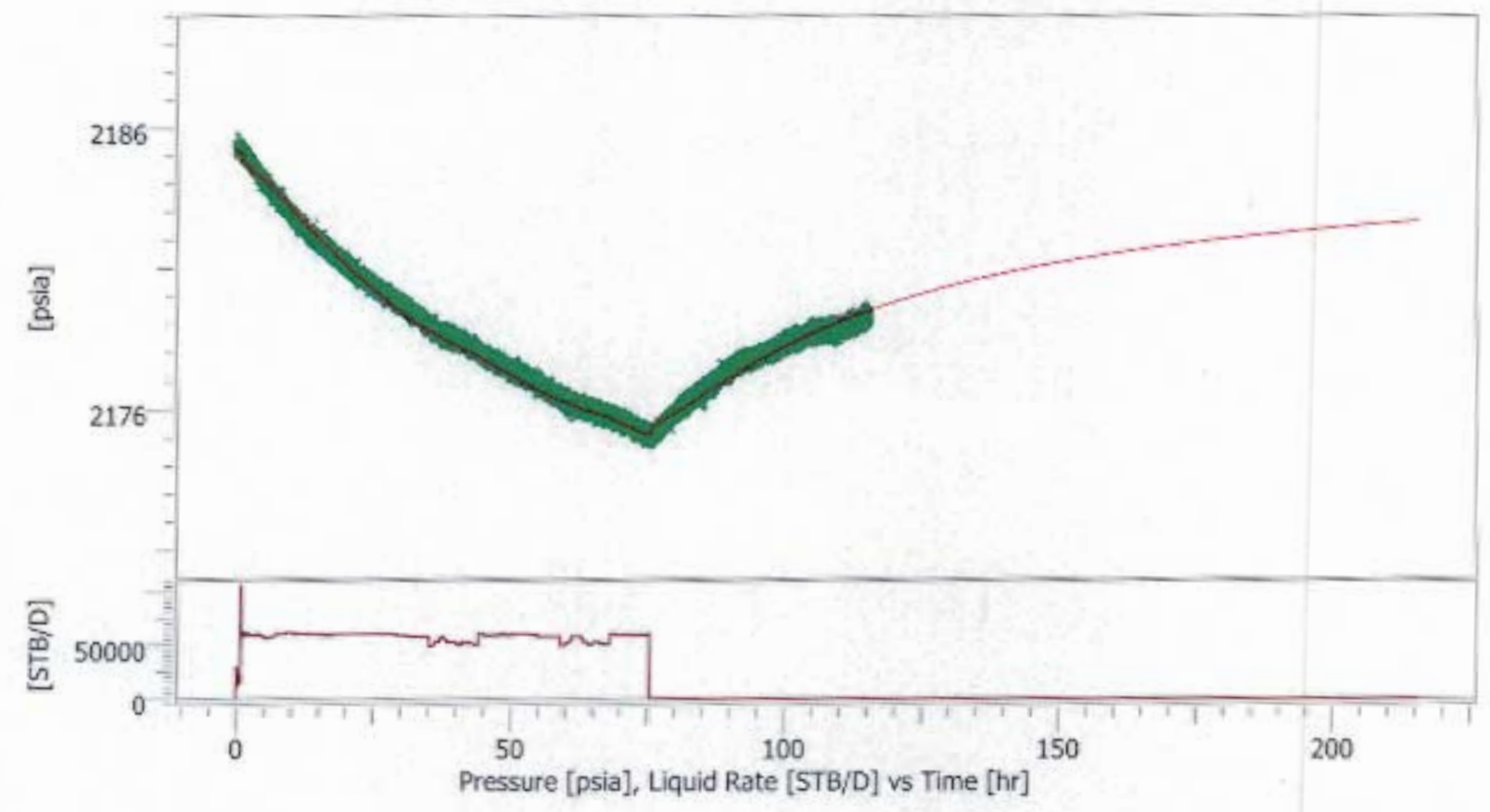

Pressure production \#1

Rate $59310 \mathrm{STB} / \mathrm{O}$

Rate change 59310 STB/D

$P @ d t=0 \quad 2185.28$ psia

Pi 2185.28 psia

Smoothing 1

Prod. Index 27.2636 [STB/D]/psia

Selected Model

Model Option Standard Model

Well Line source

Reservoir Two porosity PSS

Boundary One fault

Main Model Parameters

TMatch $0.025[\mathrm{hr}]-1$

PMatch 0.0751 [psia]-1

Phi 0.0294

Phi.h $29.4 \mathrm{ft}$

k.h, total 1.3607E $+5 \mathrm{md} . \mathrm{ft}$

$k$, average $136.07 \mathrm{md}$

Pi 2185.28 psia

Well distance $6000 \mathrm{ft}$
Model Parameters Reservoir \& Boundary parameters

Pi 2185.28 psia

k.h $1.3607 \mathrm{E}+5$ md.ft

k $136.07 \mathrm{md}$

Phi 0.0294

Phi.h $29.4 \mathrm{ft}$

Omega 0.0477

Lambda $2.55 E-8$

L- Constant P. $94700 \mathrm{ft}$

Derived \& Secondary Parameters 


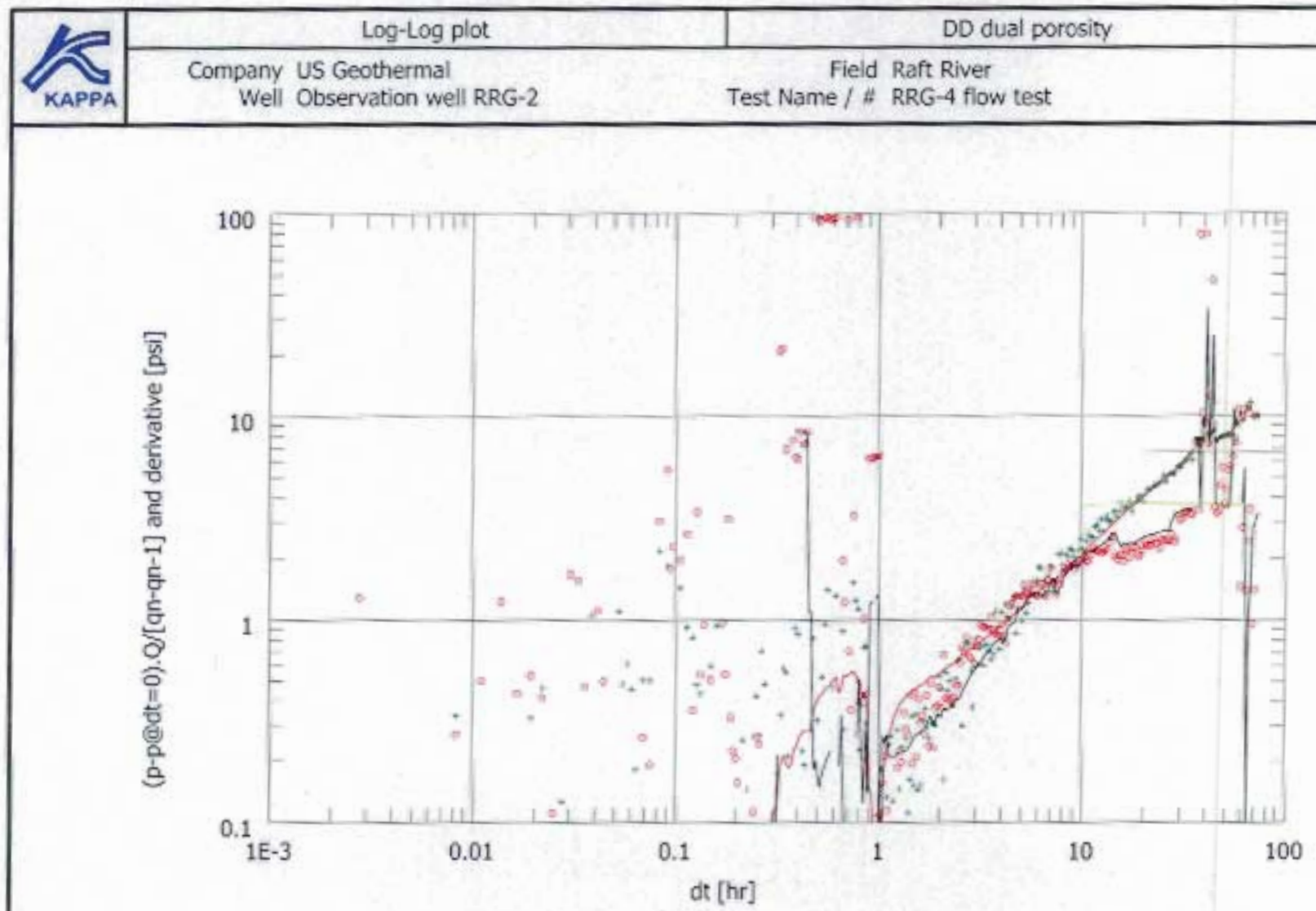

$\begin{array}{rr}\text { Pressure production } \# 1 \\ \text { Rate } & 59310 \text { STB/D } \\ \text { Rate change } & 59310 \text { STB/D } \\ \text { P@dt }=0 & 2185.28 \text { psia } \\ \text { PI } & 2185.28 \text { psia }\end{array}$

Smoothing 1

Prod. Index 27.2636 [STB/D]/psia

Selected Model

Model Option Standard Model

Well Line source

Reservoir Two porosity PSS

Boundary One fault

Main Model Parameters

TMatch $0.025[\mathrm{hr}]-1$

PMatch 0.0751 [psia]-1

Phi 0.0294

Phi.h $29.4 \mathrm{ft}$

k.h, total $1.3607 \mathrm{E}+5 \mathrm{md}, \mathrm{ft}$

$k$, average $136.07 \mathrm{md}$

Pi 2185.28 psia

Well distance $6000 \mathrm{ft}$
Model Parameters

Reservoir \& Boundary parameters

Pi 2185.28 psia

k.h $1.3607 \mathrm{E}+5 \mathrm{md} . \mathrm{ft}$

k $136.07 \mathrm{md}$

Phi 0.0294

Phi.h $29.4 \mathrm{ft}$

Omega 0.0477

Lambda $2.55 E-8$

L - Constant P. $\quad 94700 \mathrm{ft}$

Derived \& Secondary Parameters

Semilog Line (Pressure production \#1)

From $10.4111 \mathrm{hr}$

To $74.3222 \mathrm{hr}$

Slope 8.47124 psi

P(i) 1hr -16.8222 psia

PMatch 0.136 [psia]-1

k.h $2.4607 \mathrm{E}+5 \mathrm{md}$.ft

k 246.07 md

Phi 0.0176 


\begin{tabular}{|c|c|c|c|}
\hline$\exists$ & Main Results & DD dual porosity & \\
\hline KAPPA & $\begin{array}{l}\text { Company US Geothermal } \\
\text { Well Observation well RRG-2 }\end{array}$ & $\begin{array}{c}\text { Field Raft River } \\
\text { Test Name / } \\
\text { RRG-4 flow test }\end{array}$ & \\
\hline
\end{tabular}

Test date / time Formation interval Perforated interval Gauge type / \# Gauge depth

March 13-21, 2007

TEST TYPE Interference

Well distance $6000 \mathrm{ft}$ Well Radius $\mathrm{nw} \quad 0.3 \mathrm{ft}$

Pay Zone h $1000 \mathrm{ft}$

Water Salt (ppm) 10000

Form. compr. 3E-6 psi-1

Reservoir T $290^{\circ} \mathrm{F}$

Reservoir P 2500 psia

FLUID TYPE Water

Volume Factor B $\quad 1,07018$ B/STB

Viscosity $0.202066 \mathrm{CP}$

Total Compr. ct $\quad 6.71002 \mathrm{E}-6$ psi-1

Selected Model

Model Option Standard Model

Well Line source

Reservoir Two porosity PSS

Boundary One fault

Main Model Parameters

TMatch $0.025[\mathrm{hr}]-1$

PMatch 0.0751 [psia]-1

Phi 0.0294

Phi.h $29.4 \mathrm{ft}$

k.h, total $1.3607 \mathrm{E}+5 \mathrm{md} . \mathrm{ft}$

$k$, average 136.07 md

Well distance $6000 \mathrm{ft}$

Model Parameters

Reservoir \& Boundary parameters

Pi 2185.28 psia

k.h $1.3607 \mathrm{E}+5$ md.ft

k 136.07 md

Phi 0.0294

Phi.h $29.4 \mathrm{ft}$

Omega 0.0477

Lambda $2.55 E-8$

L. Constant P. $\quad 94700 \mathrm{ft}$

Derived \& Secondary Parameters 


\begin{tabular}{|c|c|c|c|}
\hline \multirow{2}{*}{$\sum_{K A P P A}$} & Semi-Log plot & DD dual porosity & \multirow{2}{*}{$\begin{array}{r}60 \\
60\end{array}$} \\
\hline & $\begin{array}{l}\text { Company US Geothermal } \\
\text { Well Observation well RRG-2 }\end{array}$ & $\begin{array}{c}\text { Field Raft River } \\
\text { Test Name / \# RRG-4 flow test }\end{array}$ & \\
\hline
\end{tabular}

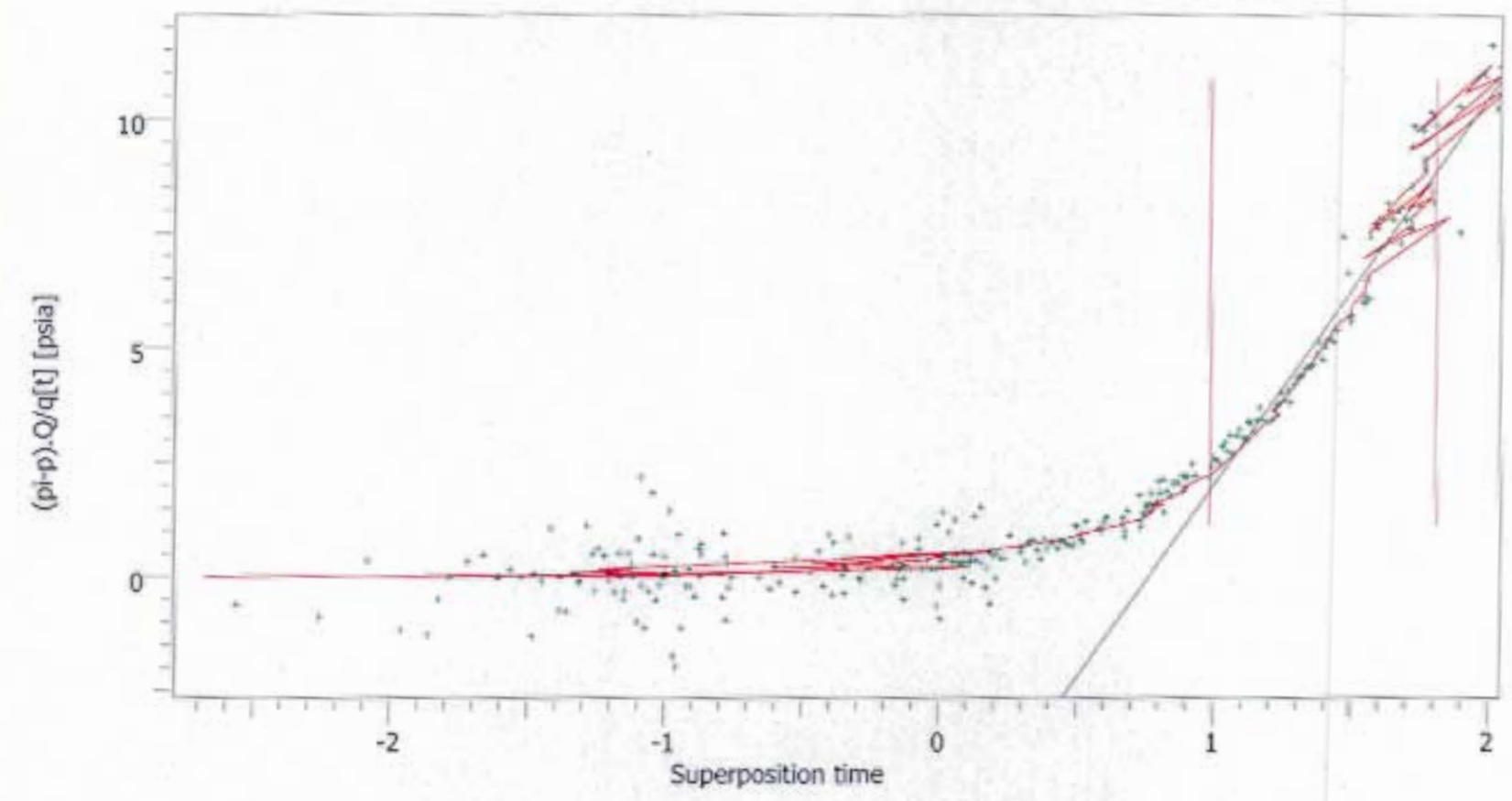

Pressure production i 1

Rate 59310 5TB/D

Rate change $593105 T$ B/D

$P(d t=0 \quad 2185.28$ psia

Pi 2185.28 psia

Smoothing 1

Prod, Index 27.2636 [STB/D]/psia

Selected Model

Model Option Standard Model

Well Line source

Reservoir Two porosity PSS

Boundary One fault

Main Model Parameters

TMatch $0.025[\mathrm{hr}]-1$

PMatch 0.0751 [psia]-1

Phi 0.0294

Phi.h $29.4 \mathrm{ft}$

k.h, total $1.3607 \mathrm{E}+5 \mathrm{md} . \mathrm{ft}$

$k$, average $136.07 \mathrm{md}$

Pi 2185.28 psia

Well distance $6000 \mathrm{ft}$
Model Parameters

Reservoir \& Boundary parameters

Pi 2185.28 psia

k.h $1.3607 E+5$ md.ft

k $136.07 \mathrm{md}$

Phi 0.0294

Phi.h $29.4 \mathrm{ft}$

Omega 0.0477

Lambda 2.55E-8

L. Constant P. $94700 \mathrm{ft}$

Derived \& Secondary Parameters

Semilog Line (Pressure production \#1)

From $10.4111 \mathrm{hr}$

To $74.3222 \mathrm{hr}$

Slope 8.47124 psi

P@1hr -16.8222 psia

PMatch 0.136 [psia]-1

k.h $2.4607 E+5$ md.ft

k 246.07 md

Phi 0.0176 


\begin{tabular}{|c|c|c|}
\hline \multirow{2}{*}{\begin{tabular}{c} 
KAPPA \\
\cline { 2 - 3 }
\end{tabular}} & $\begin{array}{c}\text { Company US Geothermal } \\
\text { Well Observation well RRG-2 }\end{array}$ & BU homogeneous \\
\hline
\end{tabular}

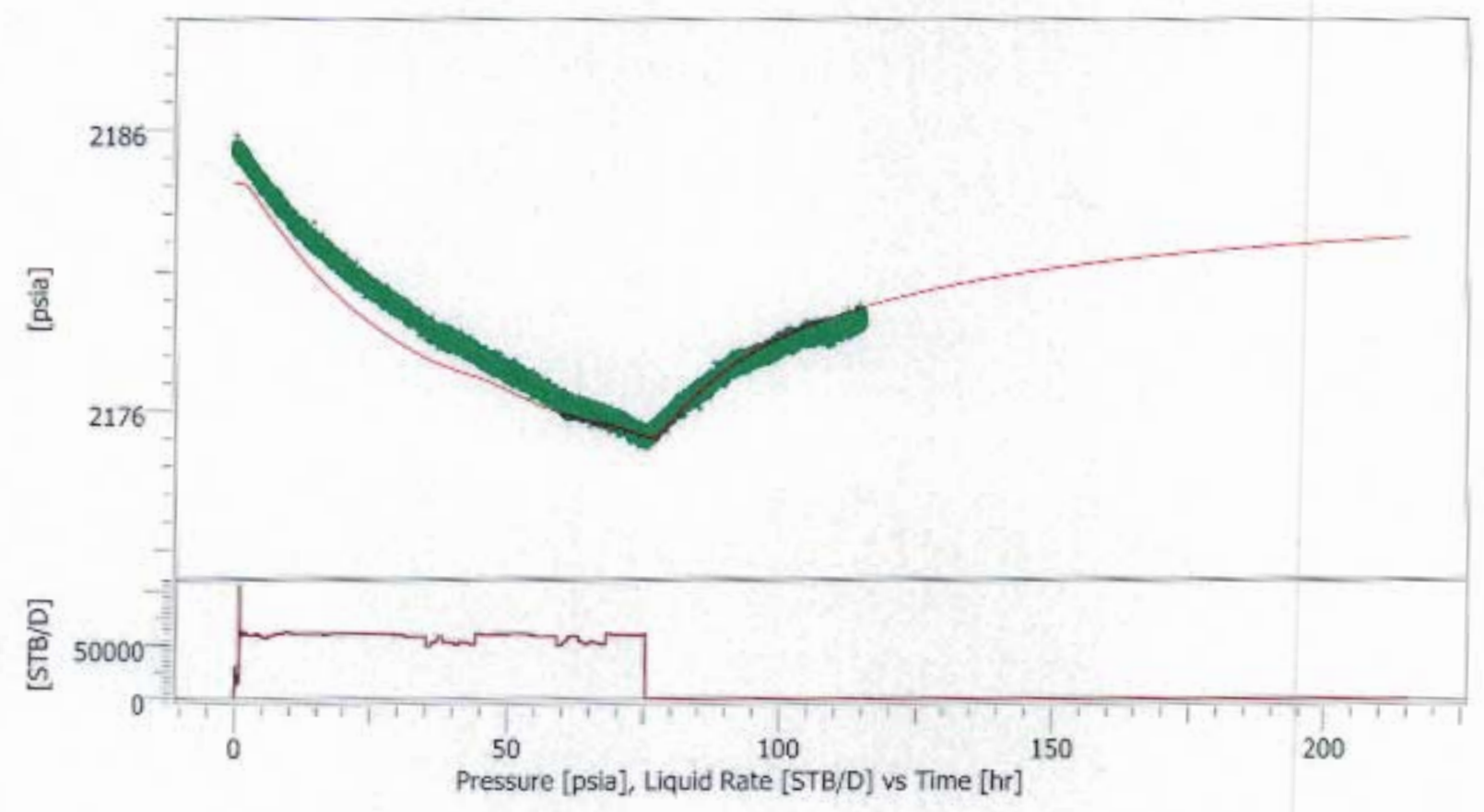

Pressure build-up \#1

Rate OSTB/D

Rate change 59310 STB/D

$P($ c) $d t=0 \quad 2175.07$ psia

Pi 2184.12 psia

5moothing 1

Prod. Index 6554.11 [STB/D]/psia

Selected Model

Model Option Standard Model

Well Line source

Reservoir Homogeneous

Boundary One fault

Main Model Parameters

TMatch $0.0711[\mathrm{hr}]-1$

PMatch 0.206 [psia]-1

Phi 0.0284

Phi.h $28.4 \mathrm{ft}$

$k$.h, total $3.7324 E+5$ md.ft

$k$, average 373.24 md

Pi 2184.12 psia

Well distance $6000 \mathrm{ft}$
Model Parameters

Reservoir \& Boundary parameters

Pi 2184.12 psia

k.h $3.7324 \mathrm{E}+5$ md.f

k 373.24 md

Phi 0.0284

Phi.h $28.4 \mathrm{ft}$

$\mathrm{L}$ - No flow $5000 \mathrm{ft}$

Derived \& Secondary Parameters 


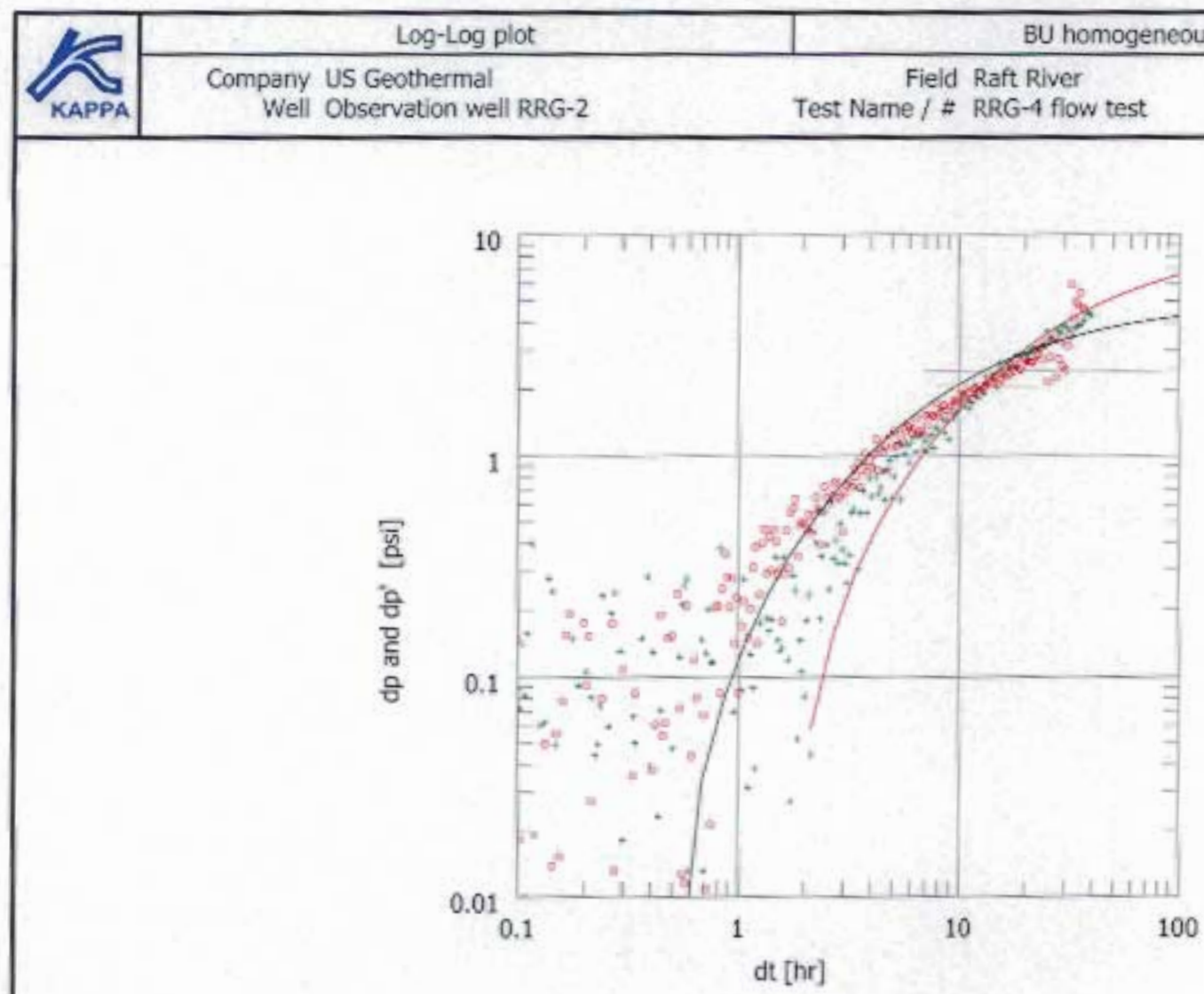

Model Parameters Reservoir \& Boundary parameters

Pi 2184.12 psia

k.h $3.7324 \mathrm{E}+5$ md.ft

k 373.24 md

Phi 0.0284

Phi.h $28.4 \mathrm{ft}$

L- No flow $5000 \mathrm{ft}$

Derived \& Secondary Parameters

Semilog Line (Pressure build-up \#1)

$\begin{array}{rl}\text { From } & 83.3722 \mathrm{hr} \\ \text { To } & 97.6222 \mathrm{hr} \\ \text { Slope } & 4.74285 \mathrm{psi} \\ \text { Itercept } & 2180.98 \mathrm{psia} \\ \text { P@ilhr } & 2172.26 \mathrm{psia} \\ \text { PMatch } & 0.243 \text { [psia]-1 } \\ \text { k.h } & 4.3951 \mathrm{E}+5 \mathrm{md} . \mathrm{ft} \\ k & 439.51 \mathrm{md} \\ p^{*} & 2180.98 \mathrm{psia} \\ \text { Phi } & 0.021\end{array}$




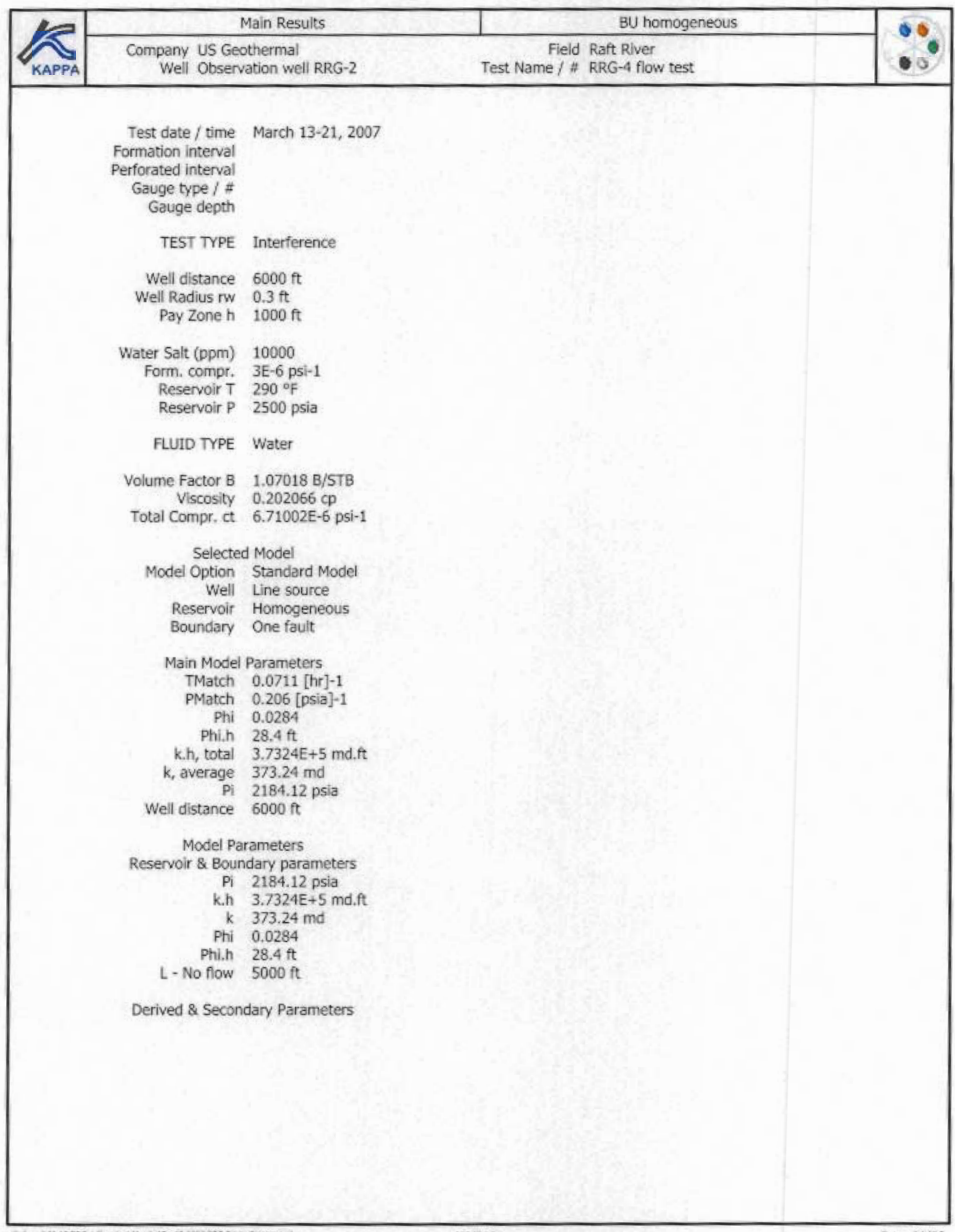




\begin{tabular}{|c|c|c|c|}
\hline \multirow{2}{*}{$\overbrace{\text { KAPPA }}$} & Semi-Log plot & BU homogeneous & \multirow{2}{*}{$\begin{array}{r}60 \\
60\end{array}$} \\
\hline & $\begin{array}{l}\text { Company US Geothermal } \\
\text { Well Observation well RRG-2 }\end{array}$ & $\begin{array}{l}\text { Field Raft River } \\
\text { Test Name / \# RRG-4 flow test }\end{array}$ & \\
\hline
\end{tabular}

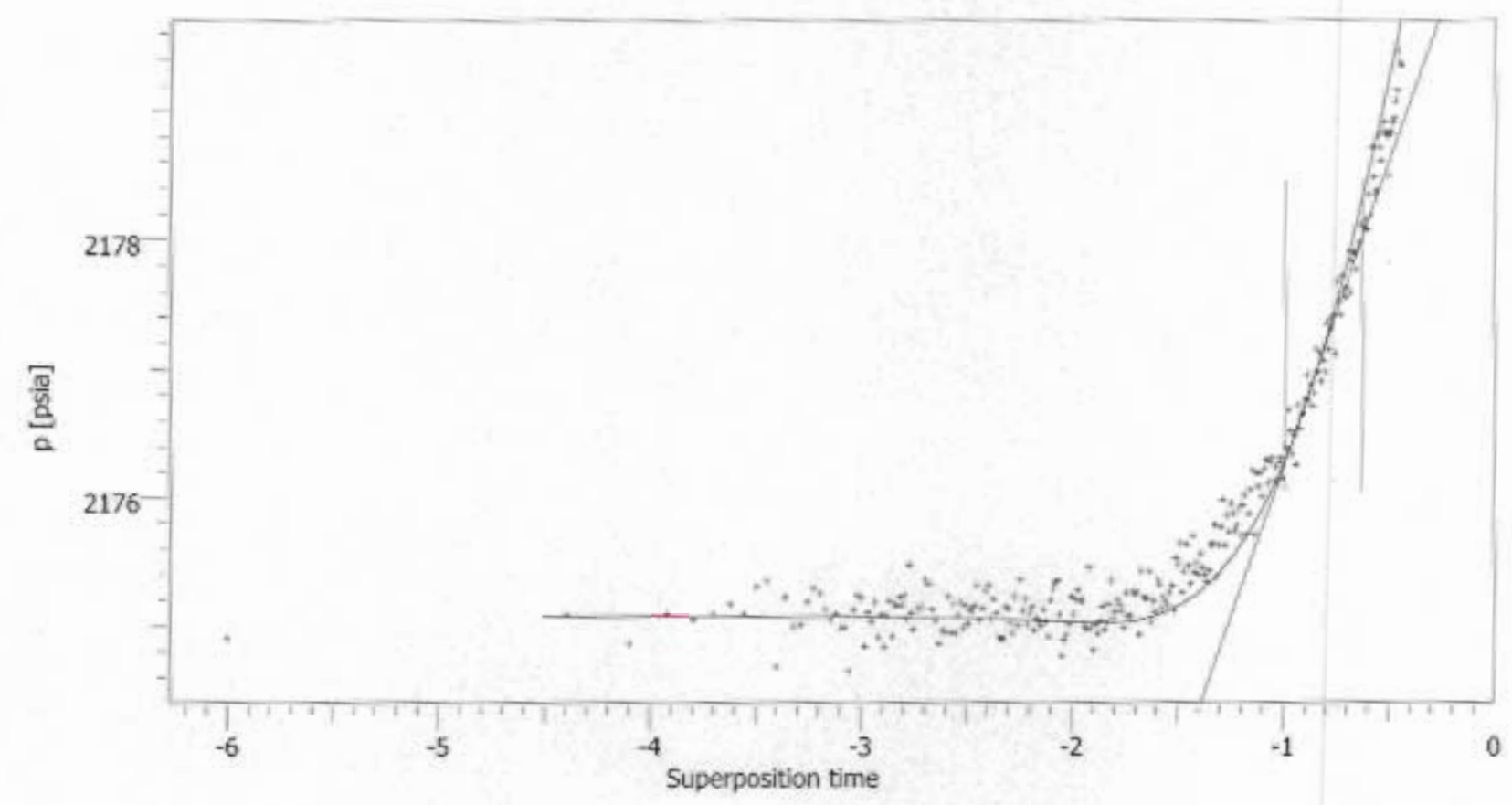

Pressure build-up \#1

$\begin{array}{rl}\text { Rate } & 05 T \mathrm{~B} / \mathrm{D} \\ \text { Rate change } & 59310 \mathrm{STB} / \mathrm{D} \\ \text { P@dt=0 } & 2175.07 \mathrm{psia} \\ \mathrm{Pi} & 2184.12 \mathrm{psia} \\ \text { Smoothing } & 1 \\ \text { Prod. Index } & 6554.11 \text { [STB/D]/psia } \\ \text { Selected Model } \\ \text { Model Option Standard Model } \\ \text { Well Line source } \\ \text { Reservoir Homogeneous } \\ \text { Boundary } & \text { One fault } \\ \text { Main Model Parameters } \\ \text { TMatch } & 0.0711 \text { [hr]-1 } \\ \text { PMatch } & 0.206 \text { [psla]-1 } \\ \text { Phi } & 0.0284 \\ \text { Phi.h } & 28.4 \mathrm{ft} \\ \text { k.h, total } & 3.7324 \mathrm{E}+5 \mathrm{md} . \mathrm{ft} \\ \text { k, average } & 373.24 \mathrm{md} \\ \text { Pi } & 2184.12 \mathrm{psia} \\ \text { Well distance } & 6000 \mathrm{ft}\end{array}$

Model Parameters Reservoir \& Boundary parameters

$$
\begin{array}{rl}
\text { Pi } & 2184.12 \text { psia } \\
\text { k.h } & 3.7324 \mathrm{E}+5 \text { md.ft } \\
k & 373.24 \text { md } \\
\text { Phi } & 0.0284 \\
\text { Phi.h } & 28.4 \mathrm{ft}
\end{array}
$$$$
\text { L- No flow } 5000 \mathrm{ft}
$$

Derived \& Secondary Parameters

Semilog Line (Pressure build-up \#1)

$$
\begin{array}{rl}
\text { From } & 83.3722 \mathrm{hr} \\
\text { To } & 97.6222 \mathrm{hr} \\
\text { Slope } & 4.74285 \mathrm{psi} \\
\text { Intercept } & 2180.98 \mathrm{psia} \\
\text { P(91hr } & 2172.26 \mathrm{psia} \\
\text { PMatch } & 0.243 \text { [psia]-1 } \\
\text { k.h } & 4.3951 \mathrm{E}+5 \mathrm{md} . \mathrm{ft} \\
k & 439.51 \mathrm{md} \\
\text { p }^{*} & 2180.98 \mathrm{psia} \\
\text { Phi } & 0.021
\end{array}
$$




\begin{tabular}{|c|c|c|c|}
\hline & History plot & BU dual porosity \\
\cline { 2 - 4 } & $\begin{array}{c}\text { Company US Geothermal } \\
\text { Well Observation well RRG-2 }\end{array}$ & $\begin{array}{c}\text { Field Raft River } \\
\text { KAPPA }\end{array}$ & Test Name / \# RRG-4 fiow test \\
\hline
\end{tabular}

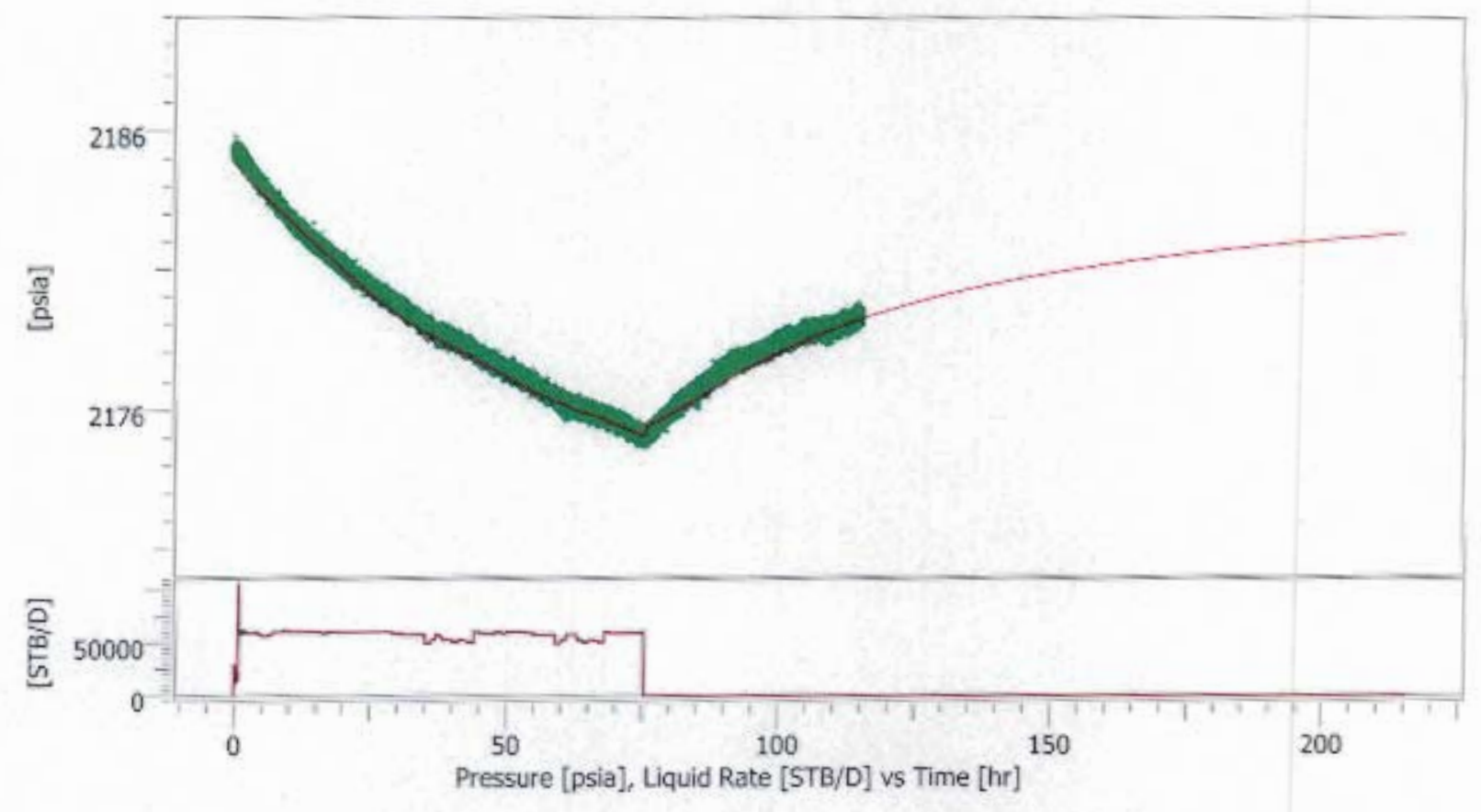

Pressure build-up \#1

Rate 0 STB/D

Rate change 59310 STB/D

$P @ d t=0 \quad 2175.07$ psia

Pi 2184.91 psia

Smoothing 1

Prod. Index 6029.89 [STB/D]/psia

Selected Model

Model Option Standard Model

Well Line source

Reservoir Two porosity PSS

Boundary One fault

Main Model Parameters

TMatch $0.0235[\mathrm{hr}]-1$

PMatch 0.0751 [psia]-1

Phi 0,0313

Phi.h $31.3 \mathrm{ft}$

k.h, total $1.3607 \mathrm{E}+5 \mathrm{md} . \mathrm{ft}$

$k$, average $136.07 \mathrm{md}$

Pi 2184.91 psia

Well distance $6000 \mathrm{ft}$
Model Parameters Reservoir \& Boundary parameters

Pi 2184.91 psia

k.h $1.3607 \mathrm{E}+5$ md.ft

k 136.07 md

Phi 0,0313

Phi.h $31.3 \mathrm{ft}$

Omega 0.0477

Lambda 2.55E-8

L - Constant P. $\quad 94700 \mathrm{ft}$

Derived \& Secondary Parameters 


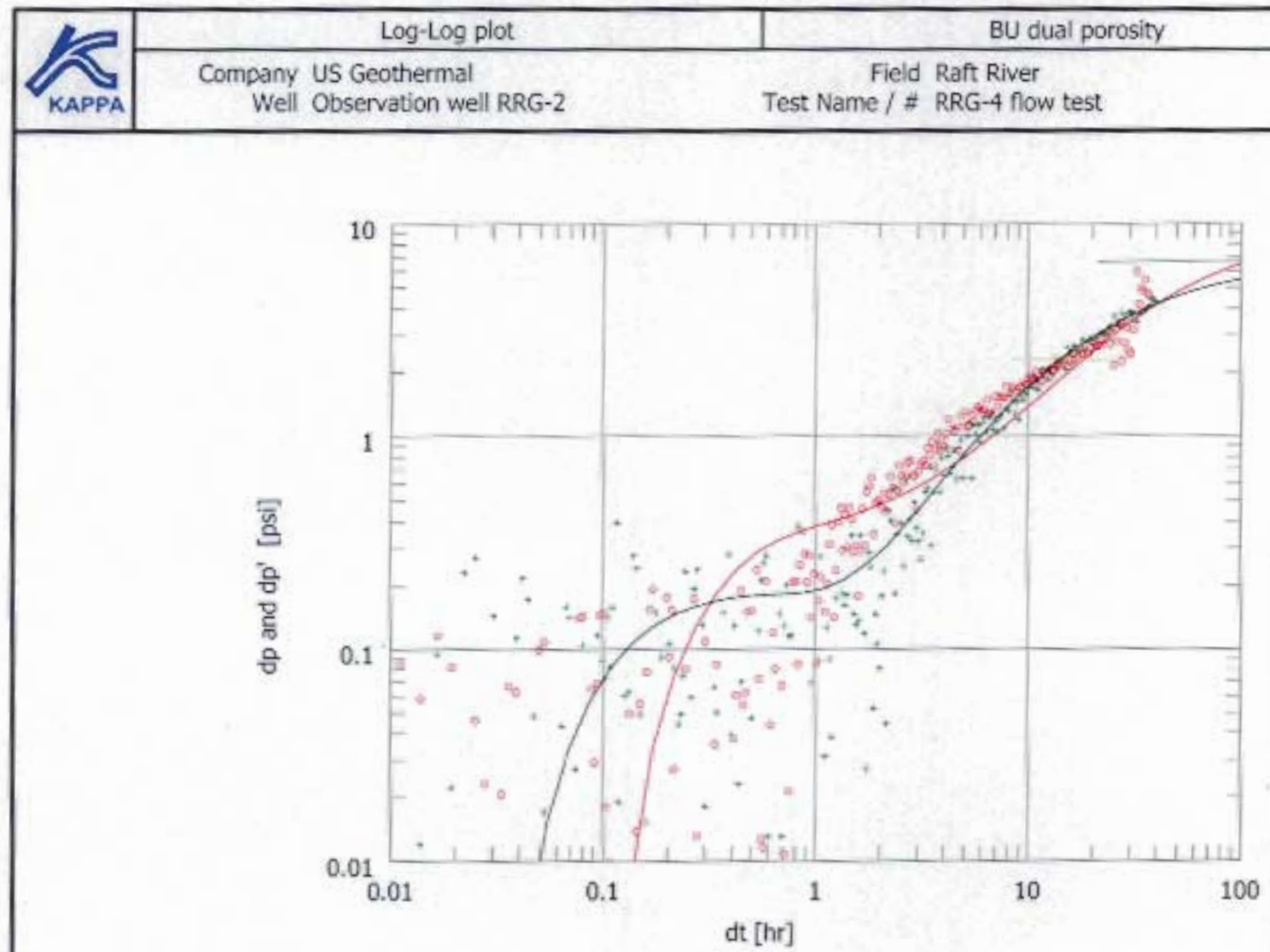

Pressure build-up \#1

Rate OSTB/D

Rate change $\$ 9310$ STB/D

P@dt $=0 \quad 2175.07$ psia

Pi 2184.91 psia

Smoothing 1

Prod. Index 6029.89 [STB/D]/psia

Selected Model

Model Option Standard Model

Well Line source

Reservoir Two porosity PSS

Boundary One fault

Main Model Parameters

TMatch $0.0235[\mathrm{hr}]-1$

PMatch 0.0751 [psia]-1

Phi 0.0313

Phi.h $31.3 \mathrm{ft}$

k.h, total 1.3607E+5 md.ft

$k$, average $136.07 \mathrm{md}$

Pi 2184.91 psia

Well distance $6000 \mathrm{ft}$
Model Parameters

Reservoir \& Boundary parameters

Pi 2184.91 psia

k.h $1.3607 \mathrm{E}+5$ md.ft

k $136.07 \mathrm{md}$

Phi 0.0313

Phi.h $31.3 \mathrm{ft}$

Omega 0.0477

Lambda 2.55E-8

L - Constant P. $\quad 94700 \mathrm{ft}$

Derived \& Secondary Parameters

Semilog Line (Pressure build-up \#1)

From $83.7444 \mathrm{hr}$

To $106.675 \mathrm{hr}$

Slope 5.2933 psi

Intercept 2181.44 psia

P@1hr 2171.7 psia

PMatch 0.217 [psia]-1

k.h $3.938 \mathrm{E}+5$ md.ft

k $393.8 \mathrm{md}$

p* 2181.44 psia

Phi 0.0209 


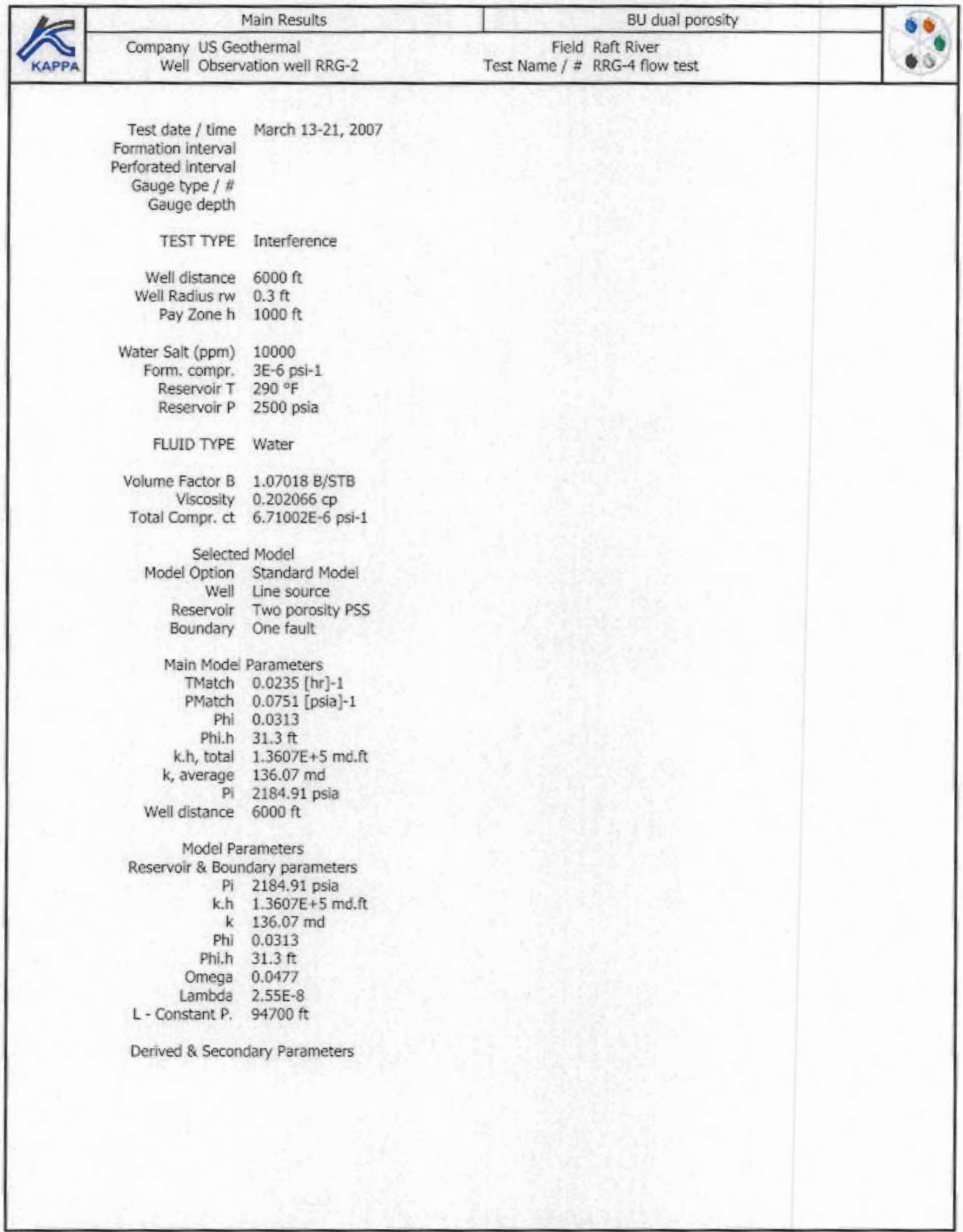




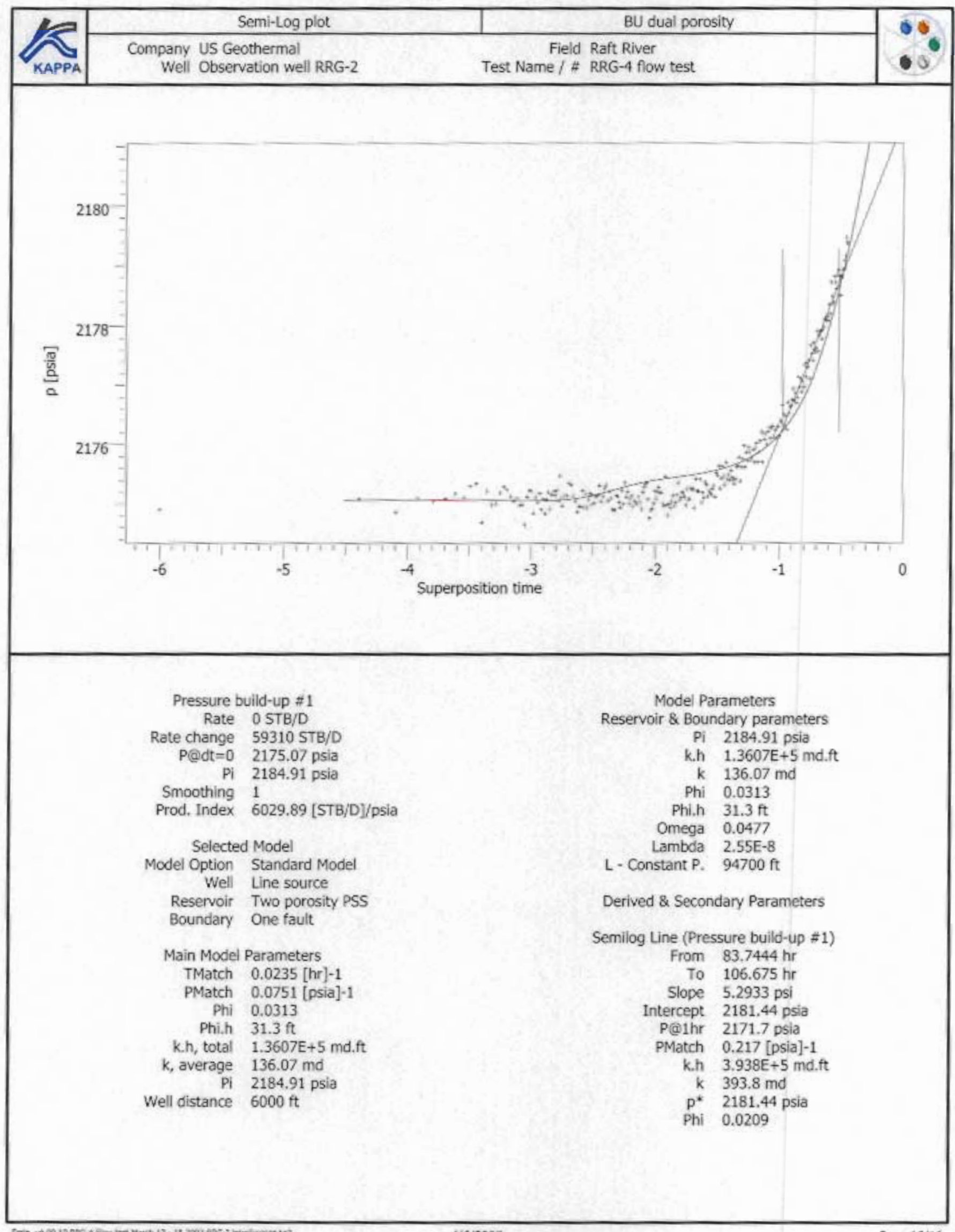

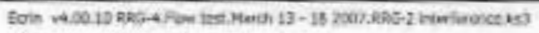




\begin{tabular}{|c|c|c|}
\hline \multirow{2}{*}{\begin{tabular}{|c|c|} 
KAPPA \\
\cline { 2 - 3 }
\end{tabular}} & $\begin{array}{c}\text { Company US Geothermal } \\
\text { Well Observation well RRG-5 }\end{array}$ & DD homogeneous \\
\hline
\end{tabular}

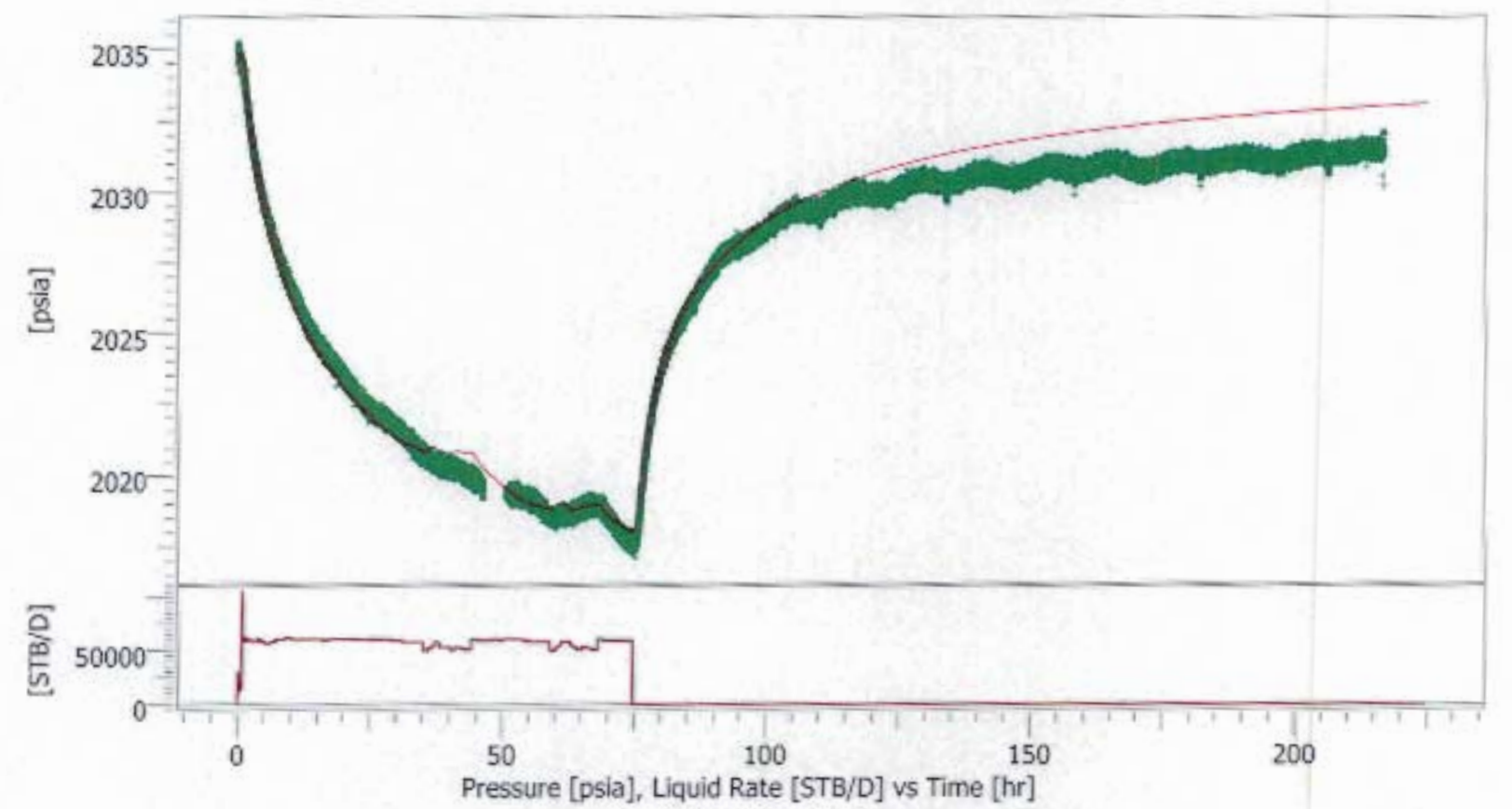

Pressure production $\# 1$

$\begin{aligned} & \text { Rate } 59310 \mathrm{STB} / \mathrm{D} \\ & \text { Rate change } 59310 \text { STB/D } \\ & \text { P@dt=0 } 2034.86 \mathrm{psia} \\ & \text { Pi } 2034.86 \mathrm{psia} \\ & \text { Smoothing } 0.5 \\ & \text { Prod. Index } 29.3947 \text { [STB/D]/psia } \\ & \text { Selected Model } \\ & \text { Model Option } \text { Standard Model } \\ & \text { Well } \text { Line source } \\ & \text { Reservoir } \text { Homogeneous } \\ & \text { Boundary } \text { One fault } \\ & \text { Main Model Parameters } \\ & \text { TMatch } 0.28 \text { [hr] }-1 \\ & \text { PMatch } 0.111 \text { [Dsia]-1 } \\ & \text { Phi } 0.0251 \\ & \text { Phi.h } 25.1 \mathrm{ft} \\ & \text { k.h, total } 2.0168 \mathrm{E}+5 \mathrm{md} . \mathrm{ft} \\ & \text { k, average } 201.68 \mathrm{md} \\ & \text { Pi } 2034.86 \mathrm{psia} \\ & \text { Well distance } 2360 \mathrm{ft}\end{aligned}$

Model Parameters Reservoir \& Boundary parameters

$$
\begin{array}{rl}
\text { Pi } & 2034.86 \text { psia } \\
\text { k.h } & 2.0168 \mathrm{E}+5 \text { md.ft } \\
k & 201.68 \mathrm{md} \\
\text { Phi } & 0.0251 \\
\text { Phi.h } & 25.1 \mathrm{ft}
\end{array}
$$

L - Constant P. $\quad 5.02 \mathrm{E}+5 \mathrm{ft}$

Derived \& Secondary Parameters 


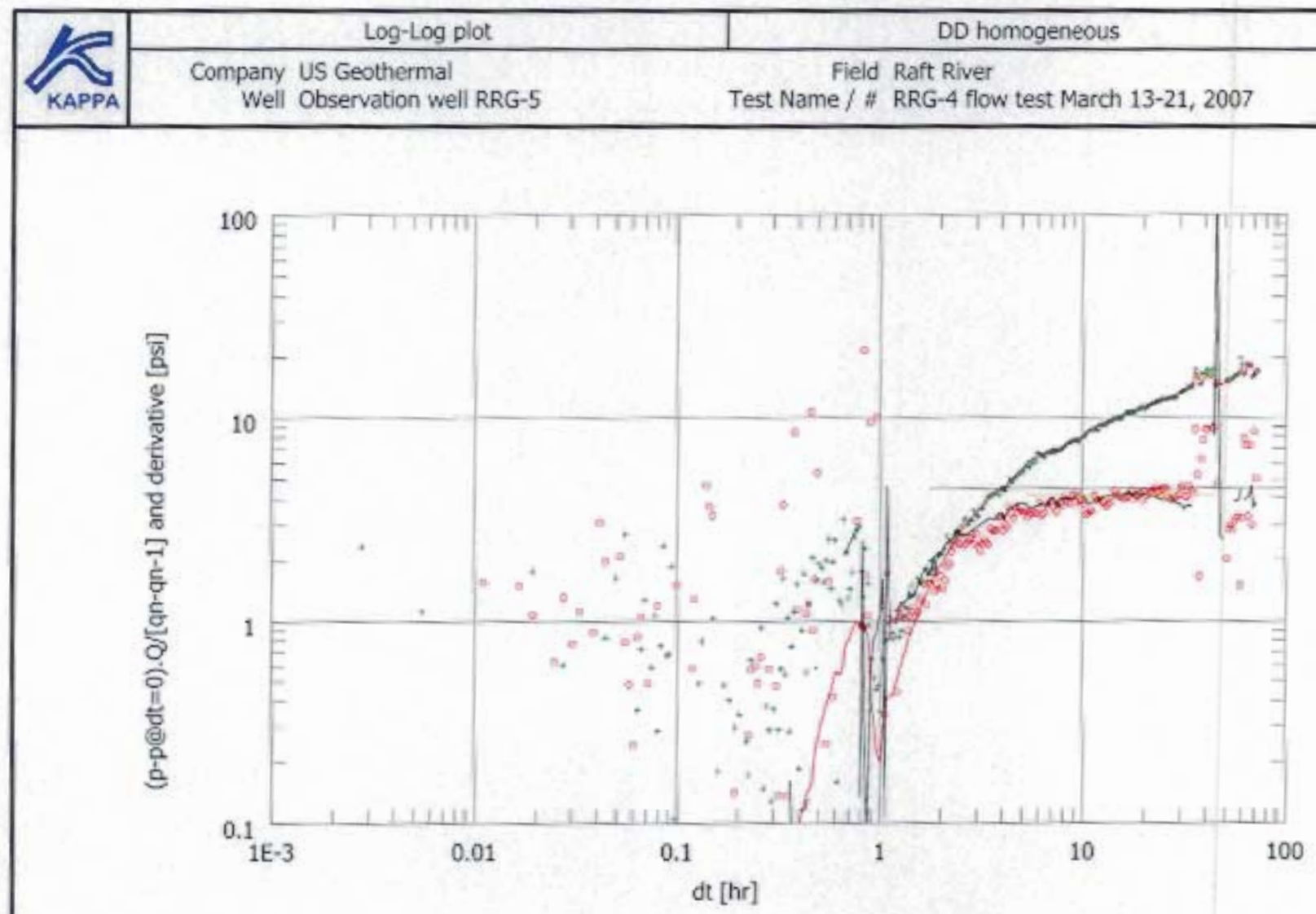

\footnotetext{
Pressure production \#1

Rate 59310 STB/D

Rate change 59310 STB/D

$P @ d t=0 \quad 2034.86$ psia

Pi 2034.86 psia

Smoothing 0.5

Prod. Index 29.3947 [STB/D]/psia

Selected Model

Model Option Standard Model

Well Line source

Reservoir Homogeneous

Boundary One fault

Main Model Parameters

TMatch $0.28[\mathrm{hr}]-1$

PMatch 0.111 [psia]-1

Phi 0.0251

Phi.h $25.1 \mathrm{ft}$

k.h, total $2,0168 \mathrm{E}+5 \mathrm{md}, \mathrm{ft}$

$k$, average $201.68 \mathrm{md}$

PI 2034.86 psia

Well distance $2360 \mathrm{ft}$
}

Model Parameters

Reservoir \& Boundary parameters

$\begin{array}{rl}\text { Pi } & 2034.86 \text { psia } \\ k h & 2.0168 \mathrm{E}+5 \text { md. } \mathrm{ft} \\ \mathrm{k} & 201.68 \mathrm{md} \\ \text { Phi } & 0.0251 \\ \text { Phi.h } & 25.1 \mathrm{ft}\end{array}$

L - Constant P. $\quad 5.02 E+5 \mathrm{ft}$

Derived \& Secondary Parameters

Semilog Line (Pressure production \#1)

From $5.34722 \mathrm{hr}$

To $44.9778 \mathrm{hr}$

Slope $9.52048 \mathrm{psi}$

P@1hr -12.5774 psia

PMatch 0.121 [psia] -1

k.h $2.1895 \mathrm{E}+5 \mathrm{md} . \mathrm{ft}$

k 218.95 md

Phi 0.0219 


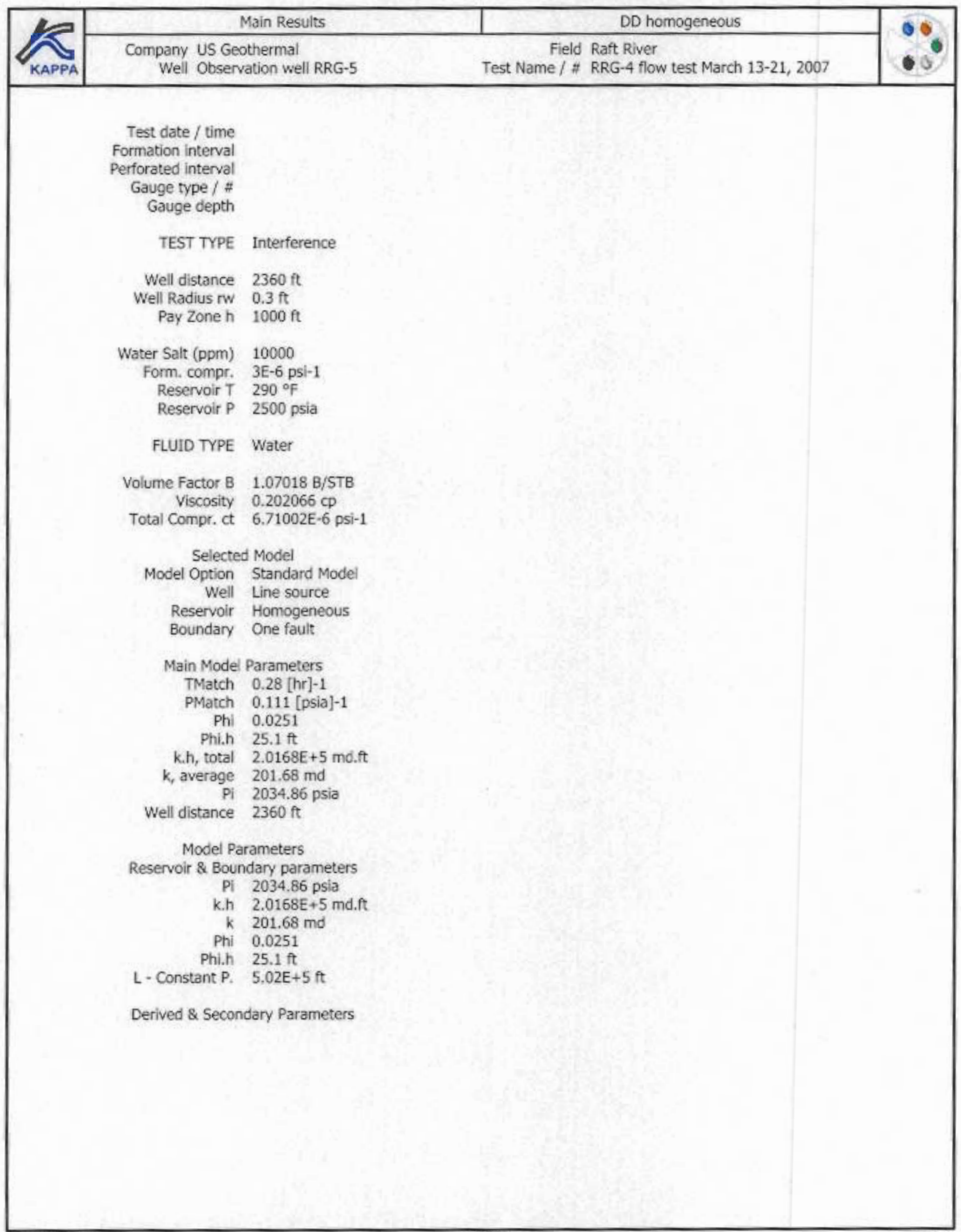




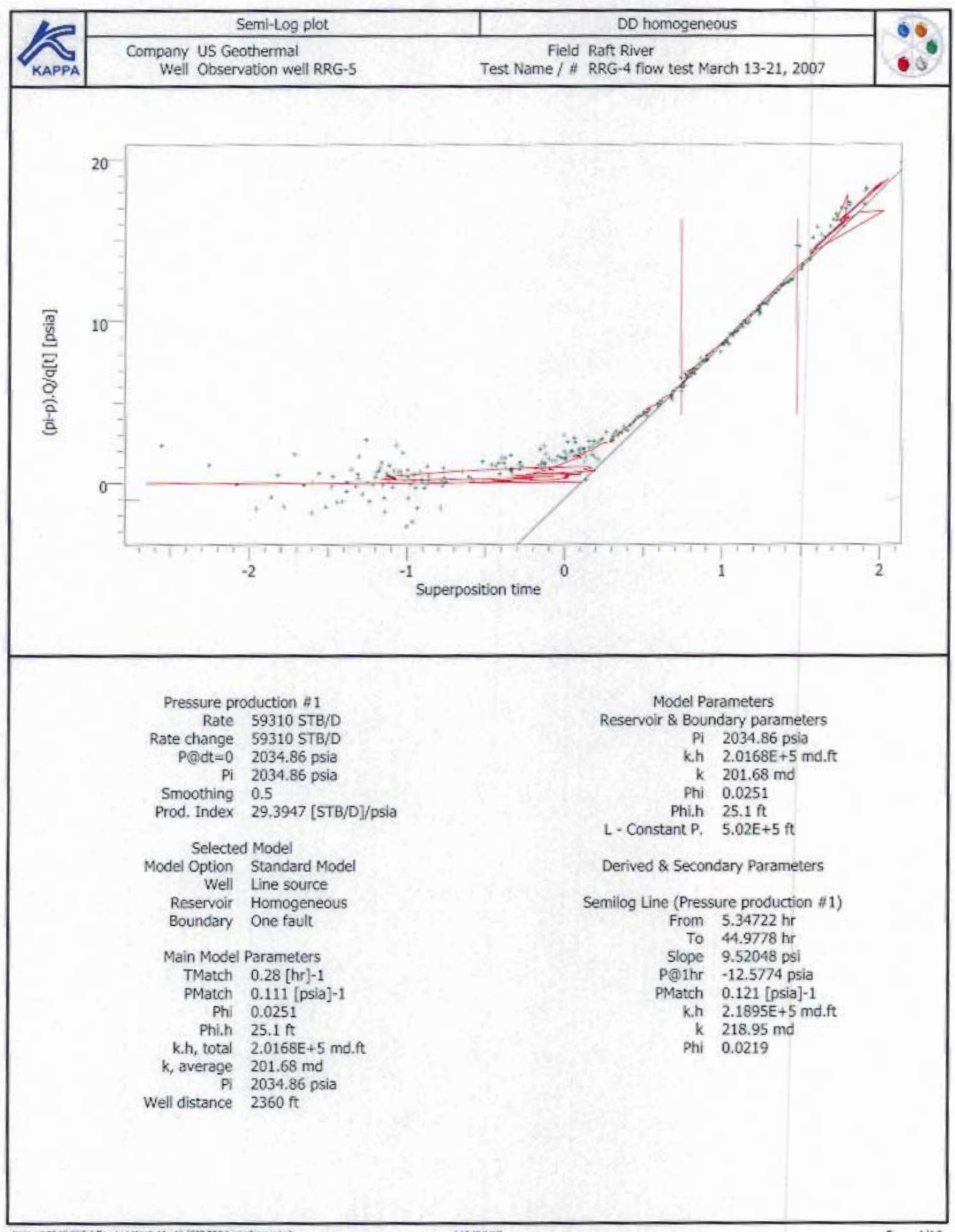




\begin{tabular}{|c|c|c|c|}
\hline \multirow{2}{*}{\begin{tabular}{|c|c|} 
KAPPA \\
\cline { 2 - 4 }
\end{tabular}} & $\begin{array}{c}\text { Company US Geothermal } \\
\text { Well Observation well RRG-5 }\end{array}$ & Fo dual porosity \\
\hline
\end{tabular}

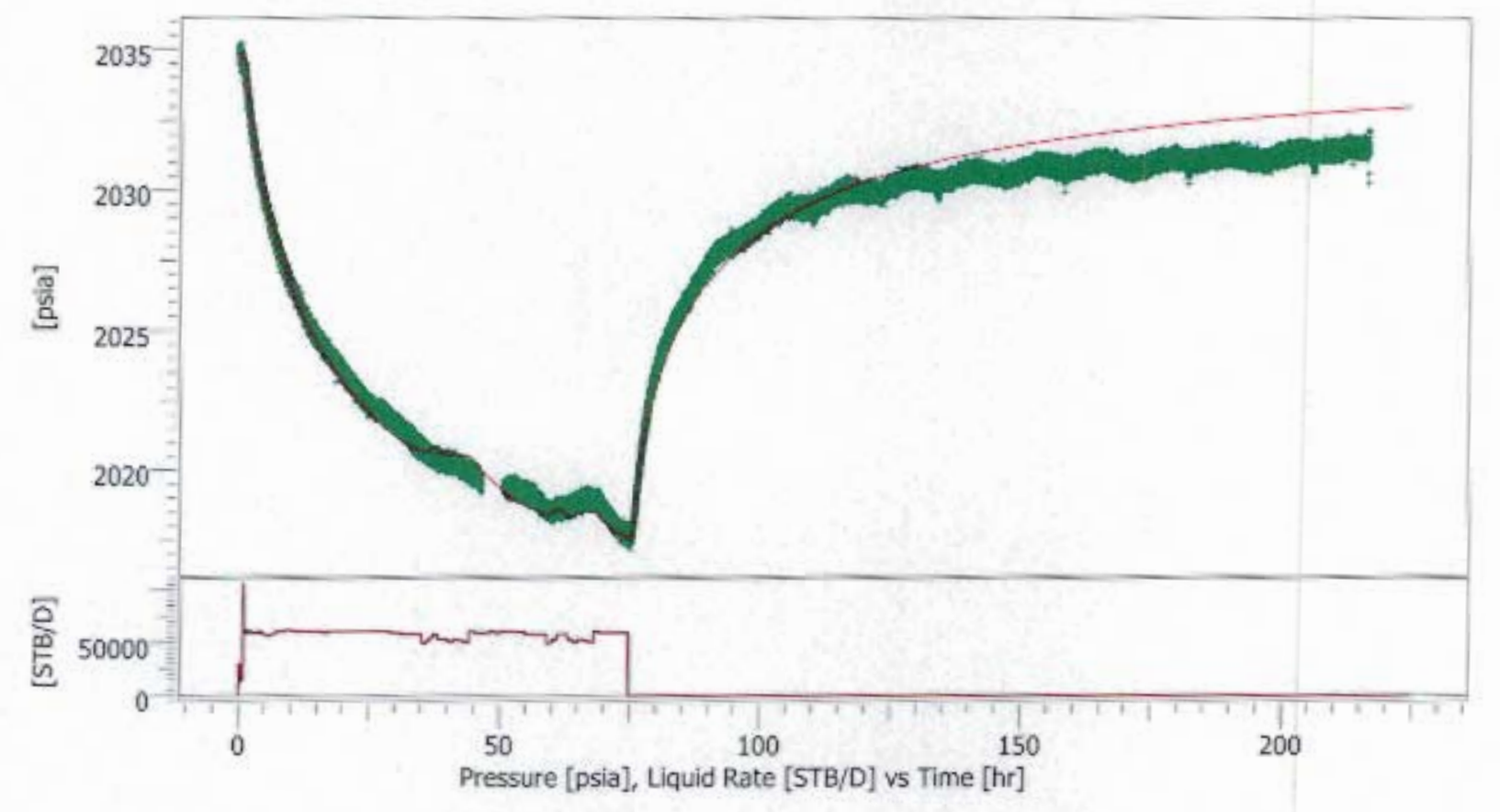

\begin{tabular}{|c|c|}
\hline \multicolumn{2}{|c|}{ Pressure build-up \#1 } \\
\hline Rate & 0 STB/D \\
\hline Rate change & 59310 STB/D \\
\hline$P(9) d t=0$ & 2017.7 psia \\
\hline $\mathrm{Pi}$ & 2034.86 psia \\
\hline Smoothing & 0.5 \\
\hline Prod. Index & $3457.3[\mathrm{STB} / \mathrm{D}] / \mathrm{psia}$ \\
\hline \multicolumn{2}{|c|}{ Selected Model } \\
\hline Model Option & Standard Model \\
\hline Well & Line source \\
\hline Reservoir & Two porosity PSS \\
\hline Boundary & One fault \\
\hline \multicolumn{2}{|c|}{ Main Model Parameters } \\
\hline TMatch & $0.221[\mathrm{hr}]-1$ \\
\hline PMatch & 0.102 [psia]-1 \\
\hline $\mathrm{Phl}$ & $0.0291^{2}$ \\
\hline Phi,h & $29.1 \mathrm{ft}$ \\
\hline k.h, total & 1.8399E +5 md.ft \\
\hline$k$, average & 183.99 md \\
\hline $\mathrm{PI}$ & 2034.86 psia \\
\hline & $2360 \mathrm{ft}$ \\
\hline
\end{tabular}

Model Parameters Reservoir \& Boundary parameters

Pi 2034.86 psia

k.h $1.8399 \mathrm{E}+5$ md.ft

k 183.99 md

Phi 0.0291

Phi,h $29.1 \mathrm{ft}$

Omega 0.689

Lambda 1.84E-4

L - Constant P. $\quad 2.81 \mathrm{E}+5 \mathrm{ft}$

Derived \& Secondary Parameters 


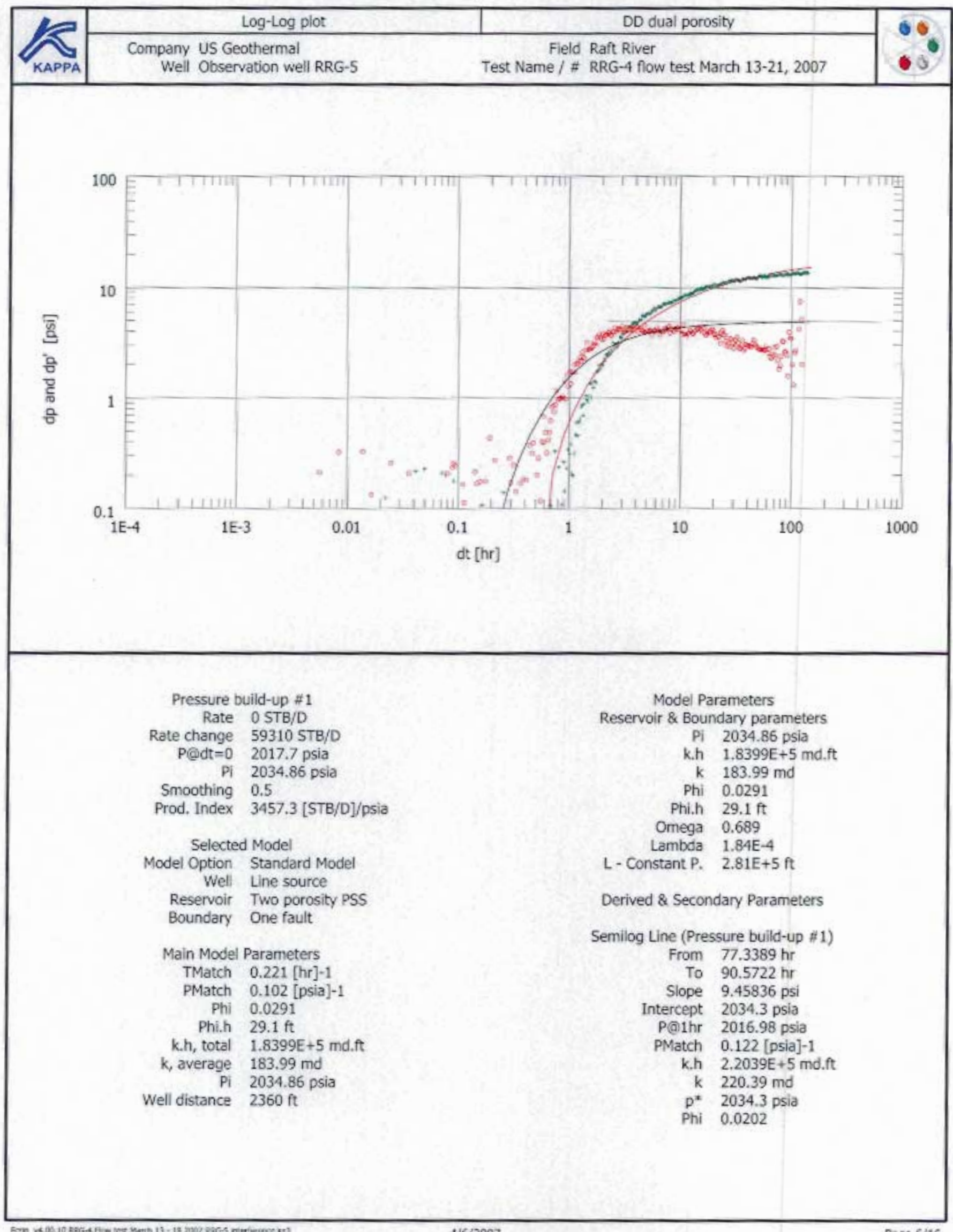




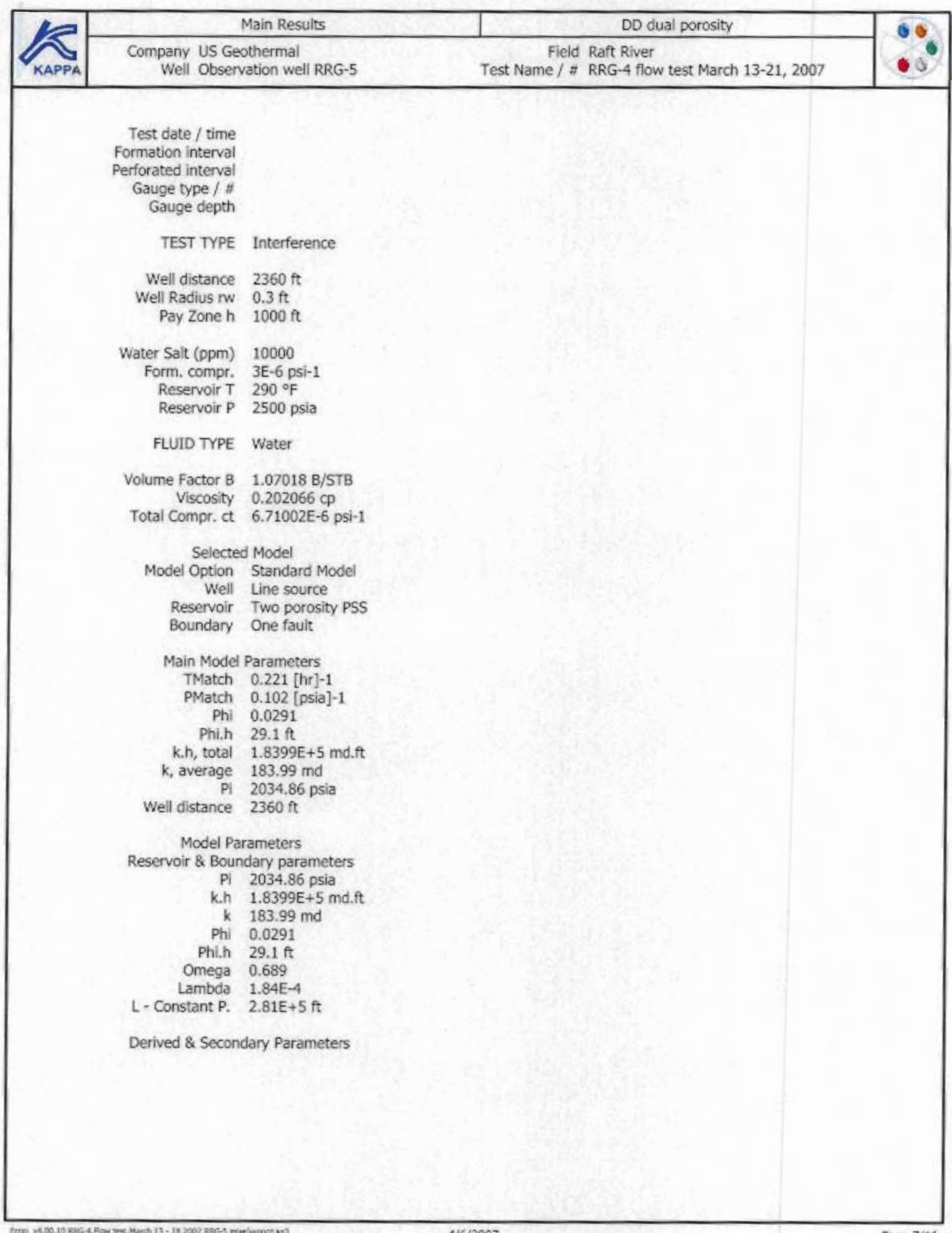




\begin{tabular}{|c|c|c|c|}
\hline \multirow{2}{*}{\begin{tabular}{c} 
KAPPA \\
\cline { 2 - 4 }
\end{tabular}} & $\begin{array}{c}\text { Company US Geothermal } \\
\text { Well Observation well RRG-5 }\end{array}$ & DD dual porosity \\
\hline
\end{tabular}

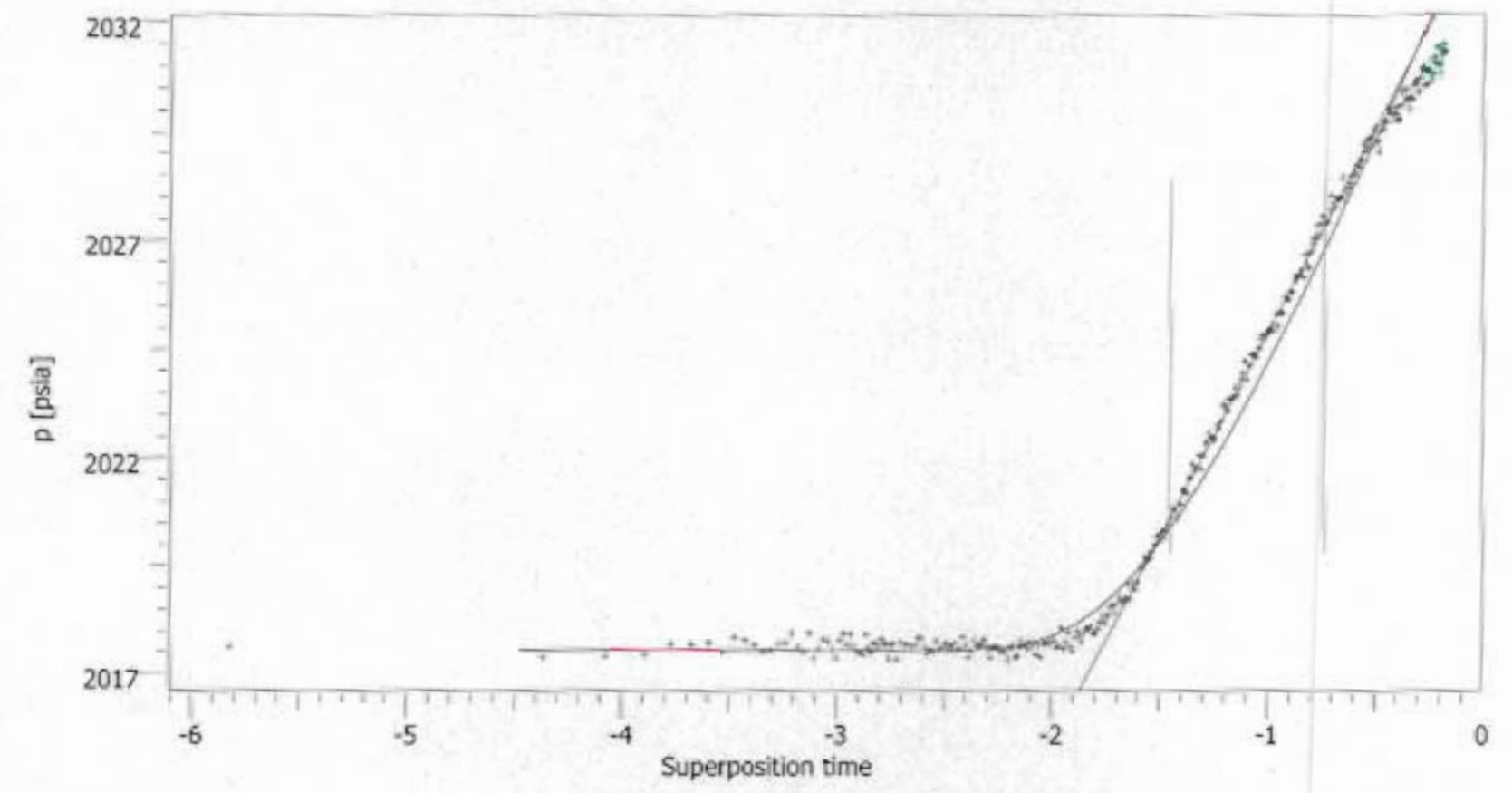

$\begin{aligned} & \text { Pressure build-up \#1 } \\ & \text { Rate } 0 \text { STB/D } \\ & \text { Rate change } 59310 \mathrm{STB} / \mathrm{D} \\ & \text { P@dt=0 } 2017.7 \mathrm{psia} \\ & \text { Pi } 2034.86 \mathrm{psia} \\ & \text { Smoothing } 0.5 \\ & \text { Prod. Index } 3457.3 \text { [STB/D]/psia } \\ & \text { Selected Model } \\ & \text { Model Option } \text { Standard Model } \\ & \text { Well } \text { Line source } \\ & \text { Reservoir } \text { Two porosity PSS } \\ & \text { Boundary } \text { One fault } \\ & \text { Main Model Parameters } \\ & \text { TMatch } 0.221 \text { [hr] }-1 \\ & \text { PMatch } 0.102 \text { [psia]-1 } \\ & \text { Phi } 0.0291 \\ & \text { Phi.h } 29.1 \mathrm{ft} \\ & \text { k.h, total } 1.8399 \mathrm{E}+5 \text { md.ft } \\ & \text { k, average } 183.99 \text { md } \\ & \text { Pi } 2034.86 \text { psia } \\ & \text { Well distance } 2360 \mathrm{ft}\end{aligned}$

Model Parameters Reservoir \& Boundary parameters

Pi 2034.86 psia

k.h $1.8399 E+5$ md.ft

k 183.99 md

Phi 0,0291

Phi.h $29.1 \mathrm{ft}$

Omega 0.689

Lambda $1.84 \mathrm{E}-4$

L - Constant P. $\quad 2.81 \mathrm{E}+5 \mathrm{ft}$

Derived \& Secondary Parameters

$$
\begin{array}{rl}
\text { Semilog Line (Pressure build-up \#1) } \\
\text { From } 77.3389 \mathrm{hr} \\
\text { To } 90.5722 \mathrm{hr} \\
\text { Slope } 9.45836 \mathrm{psi} \\
\text { Intercept } 2034.3 \mathrm{psia} \\
\text { P@1hr } 2016.98 \mathrm{psia} \\
\text { PMatch } & 0.122 \text { [psia]-1 } \\
\text { k.h } & 2.2039 \mathrm{E}+5 \mathrm{md}, \mathrm{ft} \\
k & 220.39 \mathrm{md} \\
\text { p* } & 2034.3 \mathrm{psia} \\
\text { Phi } & 0.0202
\end{array}
$$




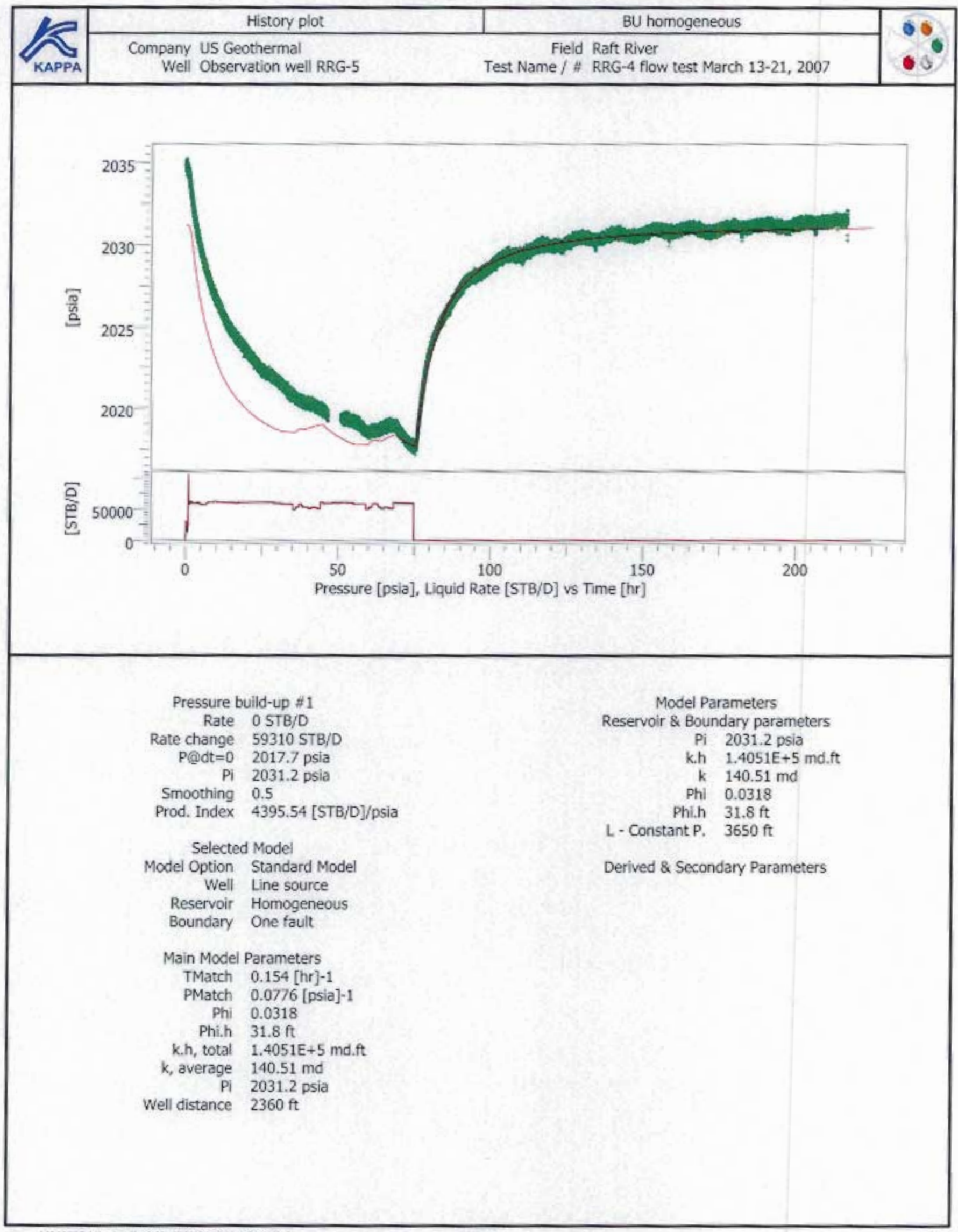

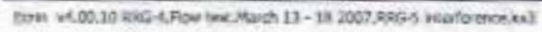

$4 / 6 / 2007$

Page 9/16 


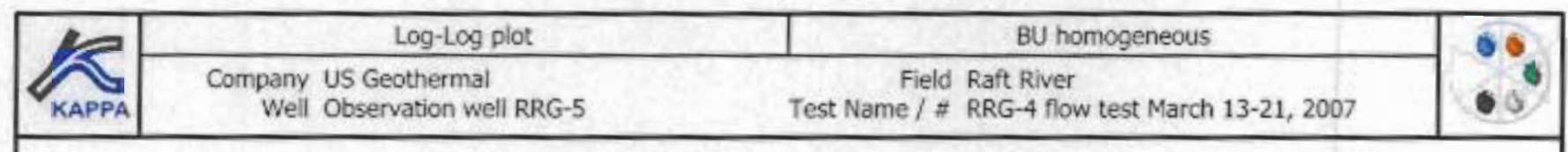

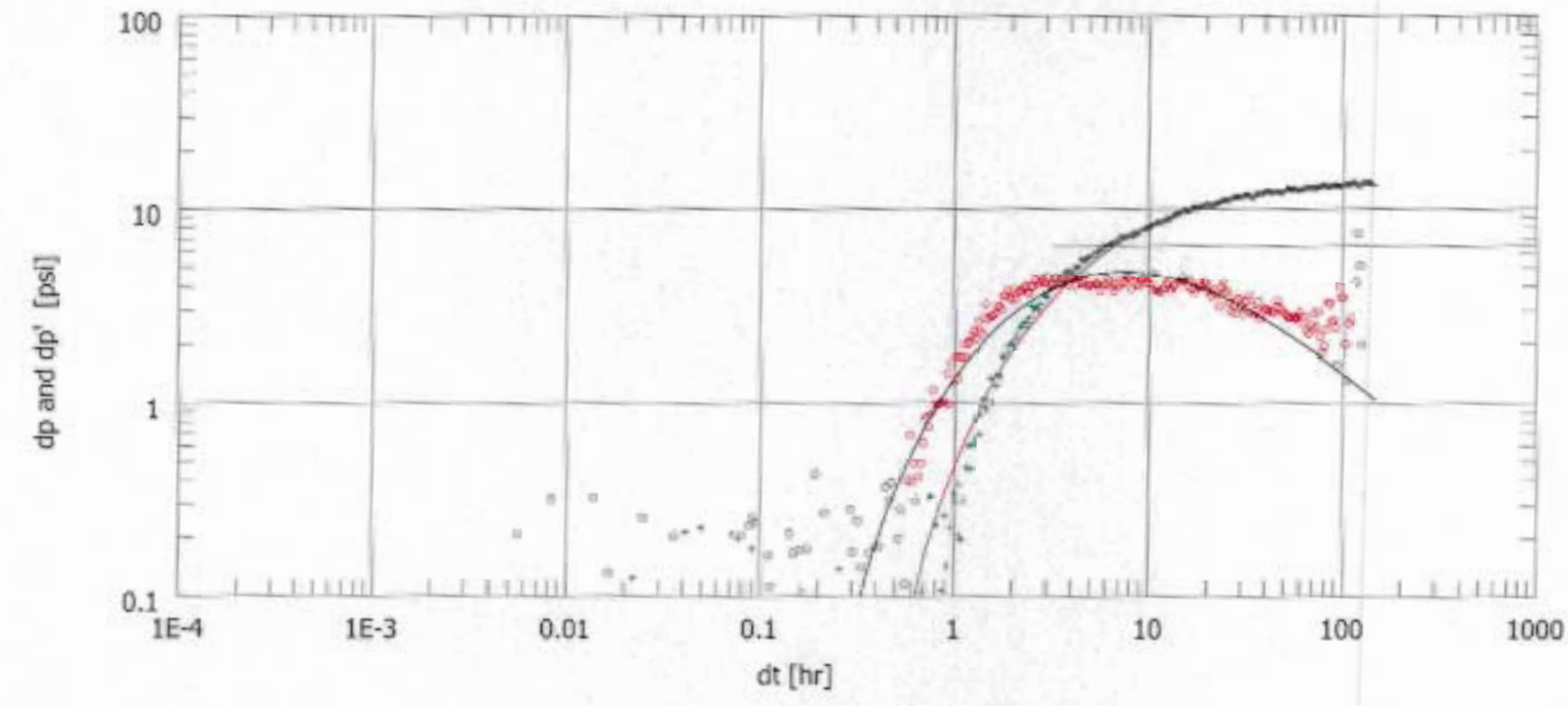

Pressure build-up \#1

Rate 0 STB/D

Rate change 59310 STB/D

P@dt $=0 \quad 2017.7$ psia

Pi 2031.2 psia

Smoothing 0.5

Prod. Index 4395.54 [STB/D]/psia

Selected Model

Model Option Standard Model

Well Line source

Reservoir Homogeneous

Boundary One fault

Main Model Parameters

TMatch $0.154[\mathrm{hr}]-1$

PMatch 0.0776 [psia]-1

Phi 0.0318

Phi.h $31.8 \mathrm{ft}$

k.h, total $1.4051 \mathrm{E}+5 \mathrm{md} . \mathrm{ft}$

$k$, average 140.51 md

Pi 2031.2 psia

Well distance $2360 \mathrm{ft}$
Model Parameters

Reservoir \& Boundary parameters

$\begin{array}{rl}\mathrm{Pi} & 2031.2 \mathrm{psia} \\ \mathrm{k.h} & 1.4051 \mathrm{E}+5 \mathrm{md} . \mathrm{ft}\end{array}$

k $140.51 \mathrm{md}$

Phi 0.0318

Phi.h $31.8 \mathrm{ft}$

L - Constant P. $\quad 3650 \mathrm{ft}$

Derived \& Secondary Parameters

Semilog Line (Pressure build-up \#1)

From $78.0667 \mathrm{hr}$

To $92.0778 \mathrm{hr}$

Slope $9.41803 \mathrm{psi}$

Intercept 2034.27 psia

P@1hr 2017.02 psia

PMatch 0.122 [psia]-1

$k . h \quad 2.2133 E+5$ md.ft

k 221.33 md

p* 2034.27 psia

Phi 0.0201 


\begin{tabular}{|c|c|c|}
\hline \multicolumn{1}{|c|}{ Main Results } & BU homogeneous \\
\cline { 2 - 4 } & $\begin{array}{c}\text { Company US Geothermal } \\
\text { Well Observation well RRG-5 }\end{array}$ & Field Raft River \\
\hline
\end{tabular}

Test date / time Formation interval

Perforated interval

Gauge type / \#

Gauge depth

TEST TYPE Interference

Well distance $2360 \mathrm{ft}$

Well Radius $\mathrm{rw} \quad 0.3 \mathrm{ft}$

Pay Zone h $1000 \mathrm{ft}$

Water Salt (ppm) 10000

Form. compr. 3E-6 psi-1

Reservoir T $290^{\circ} \mathrm{F}$

Reservoir P 2500 psia

FLUID TYPE Water

volume Factor B $1.07018 \mathrm{~B} / \mathrm{STB}$

Viscosity $0.202066 \mathrm{cP}$

Total Compr. ot $\quad 6.71002$ E-6 psi-1

Selected Model

Model Option Standard Model

Well Line source

Reservoir Homogeneous

Boundary One fault

Main Model Parameters

TMatch $0.154[\mathrm{hr}]-1$

PMatch 0.0776 [psia]-1

Phi 0.0318

Phi.h $31.8 \mathrm{ft}$

k.h, total $1.4051 \mathrm{E}+5 \mathrm{mo}, \mathrm{ft}$

$\mathrm{k}$, average $140.51 \mathrm{md}$

Pi 2031.2 psia

Well distance $2360 \mathrm{ft}$

Model Parameters

Reservoir \& Boundary parameters

Pi 2031.2 psia

k.h $1.4051 E+5$ md.ft

k 140.51 md

Phi 0.0318

Phi.h $31.8 \mathrm{ft}$

L-Constant P. $\quad 3650 \mathrm{ft}$

Derived \& Secondary Parameters 


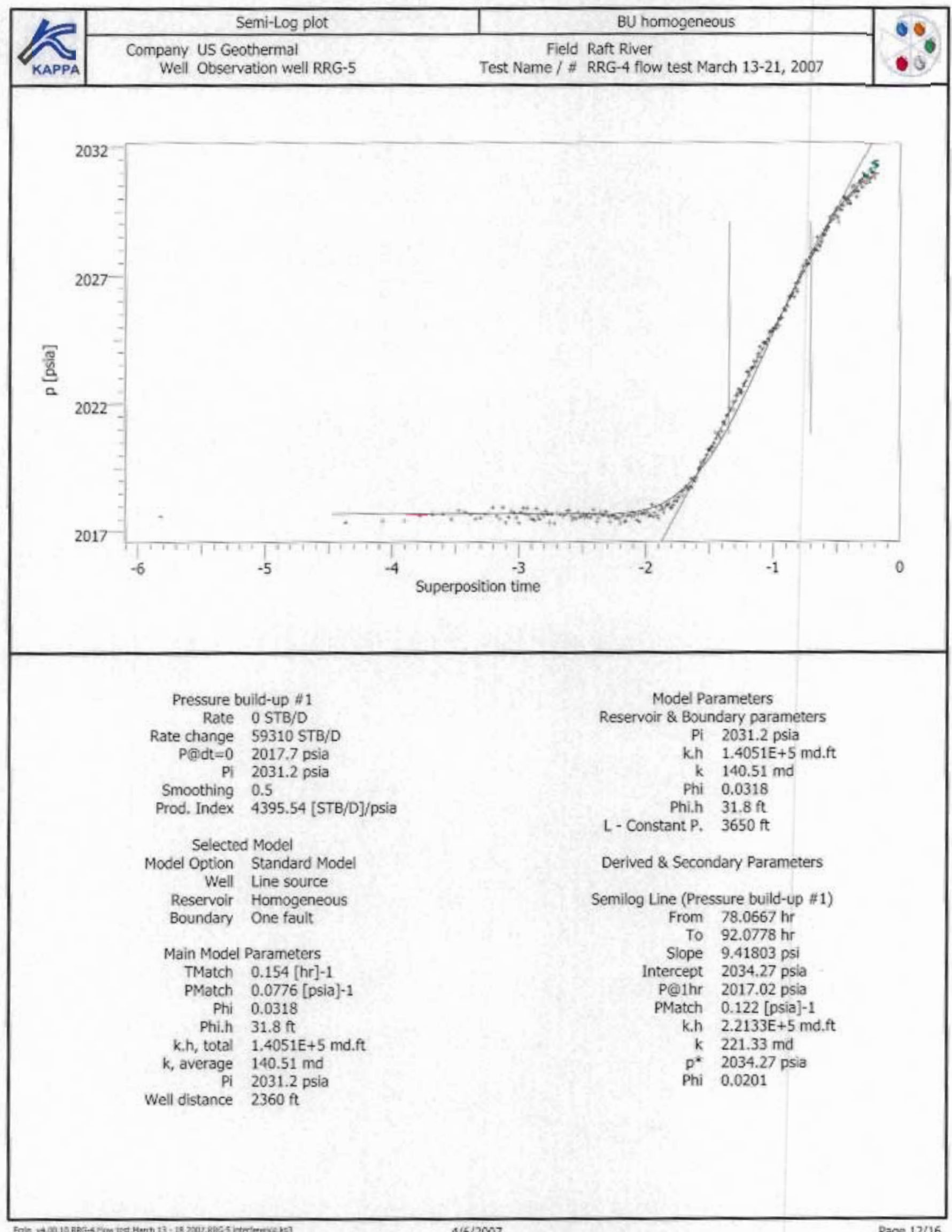




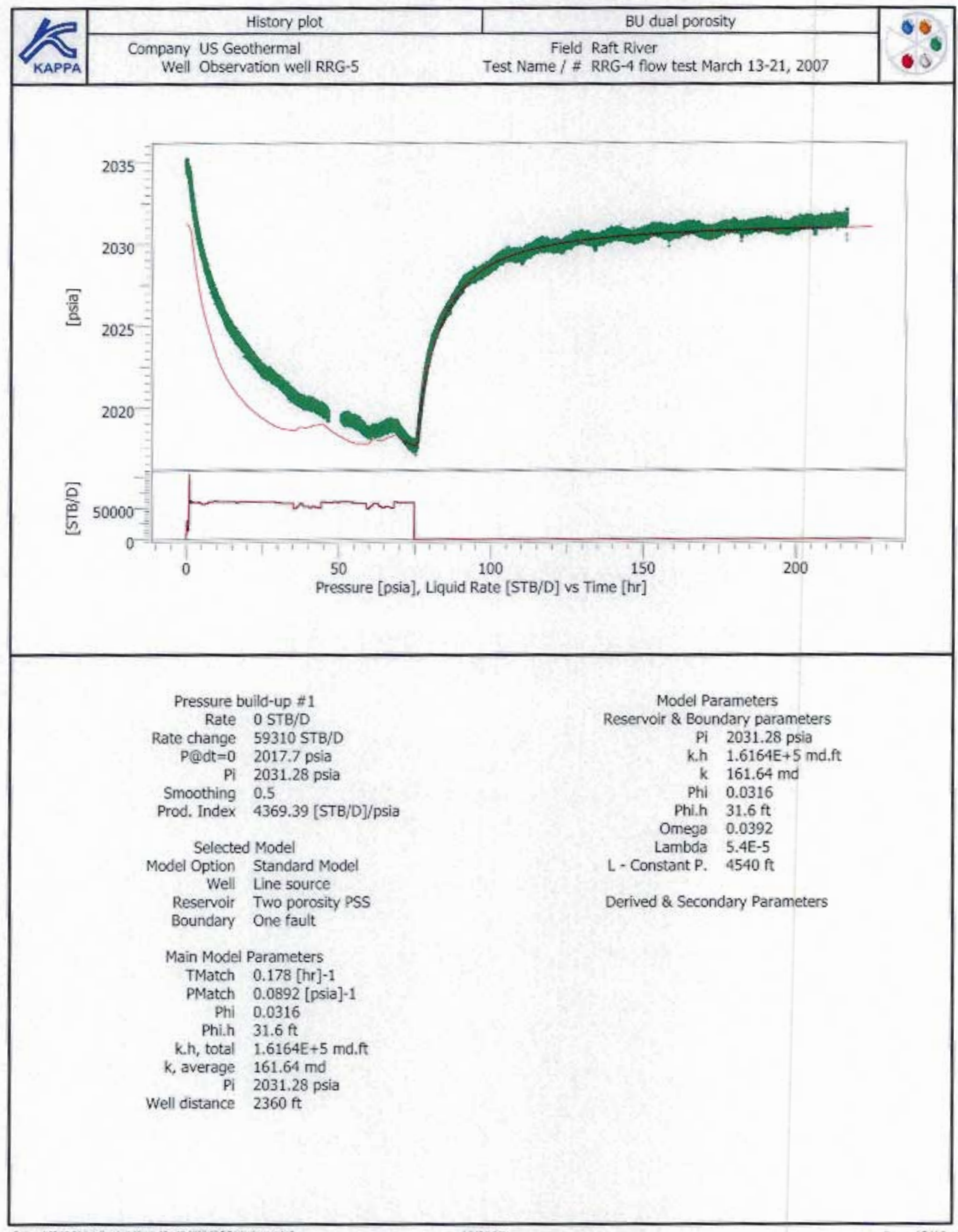

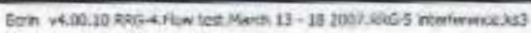




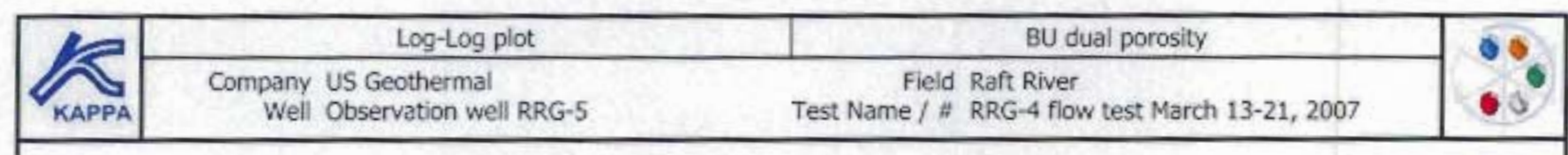

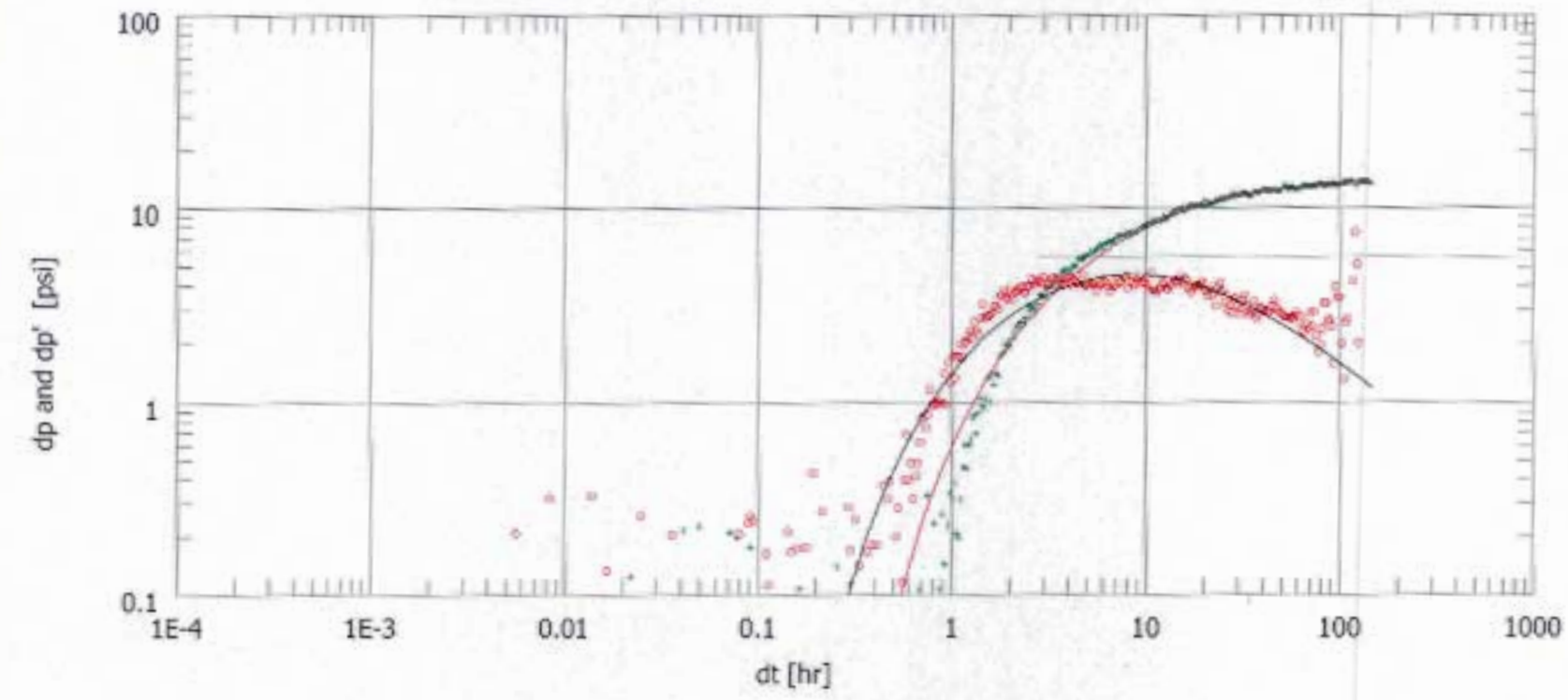

Pressure build-up \#1

Rate 0 STB/D

Rate change 59310 STB/D

$P(0) d t=0 \quad 2017.7$ psia

Pi 2031.28 psia

Smoothing 0.5

Prod. Index 4369.39 [STB/D]/psia

Selected Model

Model Option Standard Model

Well Line source

Reservoir Two porosity PSS

Boundary One fault

Main Model Parameters

TMatch $0.178[\mathrm{hr}]-1$

PMatch 0.0892 [psia]-1

Phi 0.0316

Phi.h $31.6 \mathrm{ft}$

k.h, total $1.6164 E+5$ md.ft

$k$, average 161.64 md

Pi 2031.28 psia

Well distance $2360 \mathrm{ft}$

Model Parameters

Reservoir \& Boundary parameters

Pi 2031.28 psia

k.h $1.6164 \mathrm{E}+5$ md.ft

k 161.64 md

Phi 0.0316

Phi.h $31.6 \mathrm{ft}$

Omega 0.0392

Lambda 5,4E-5

L - Constant P. $4540 \mathrm{ft}$

Derived \& Secondary Parameters

Semilog Line (Pressure build-up \#1)

$\begin{array}{rl}\text { From } & 77.7139 \mathrm{hr} \\ \text { To } & 93.3028 \mathrm{hr} \\ \text { Slope } & 9.45073 \mathrm{psi} \\ \text { tercept } & 2034.31 \mathrm{psia} \\ \text { P(1) } 1 \mathrm{hr} & 2017 \text { psia } \\ \text { PMatch } & 0.122 \text { [psia]-1 } \\ \text { k.h } & 2.2057 \mathrm{E}+5 \mathrm{md} . \mathrm{ft} \\ \text { k } & 220.57 \mathrm{md} \\ \text { p* }^{*} & 2034.31 \text { psia } \\ \text { Phi } & 0.0201\end{array}$




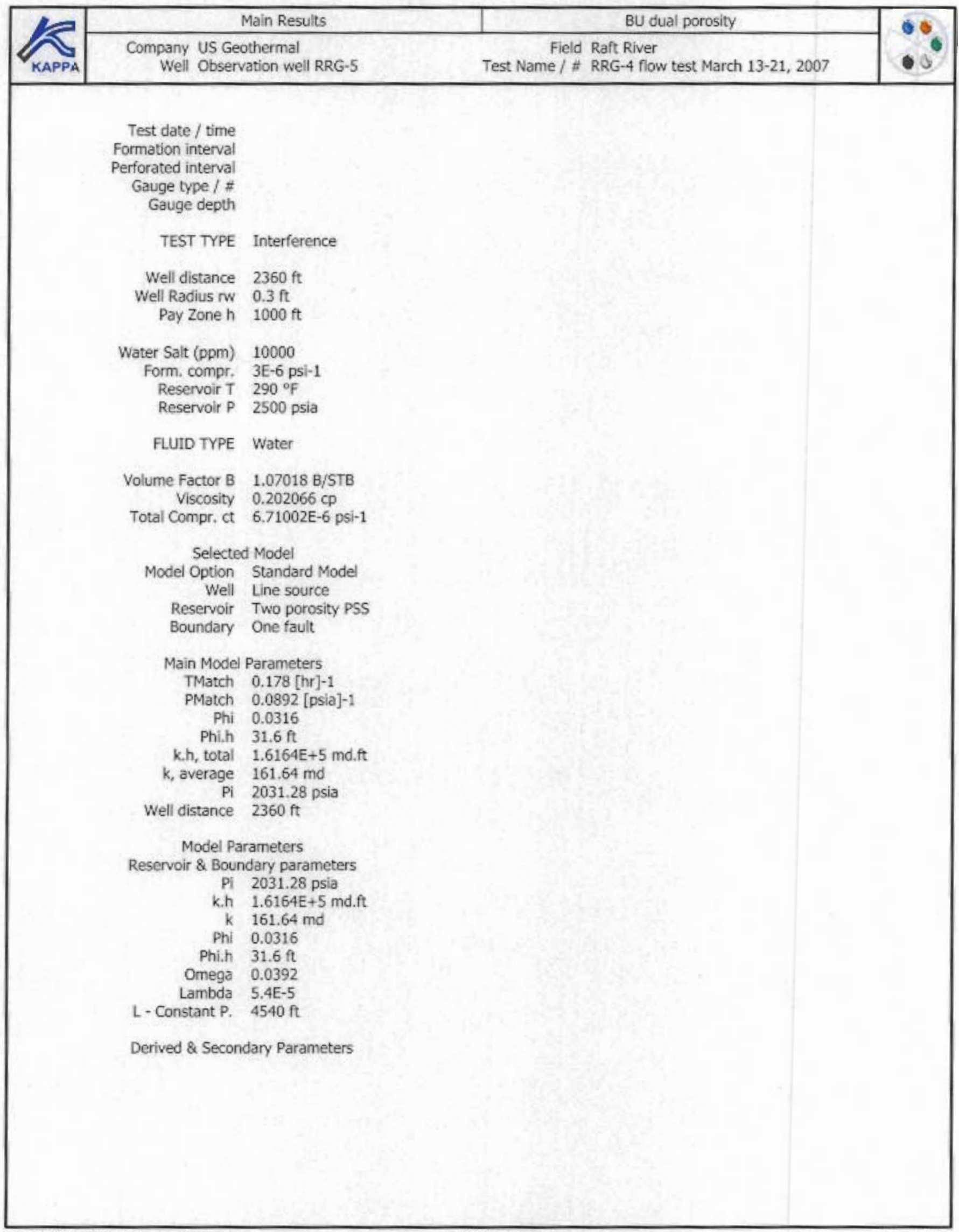




\begin{tabular}{|c|c|c|c|}
\hline \multirow{2}{*}{\begin{tabular}{c|c|} 
KAPPA \\
\cline { 2 - 4 }
\end{tabular}} & $\begin{array}{c}\text { Company US Geothermat } \\
\text { Well Observation well RRG-5 }\end{array}$ & Field Raft River \\
\hline
\end{tabular}

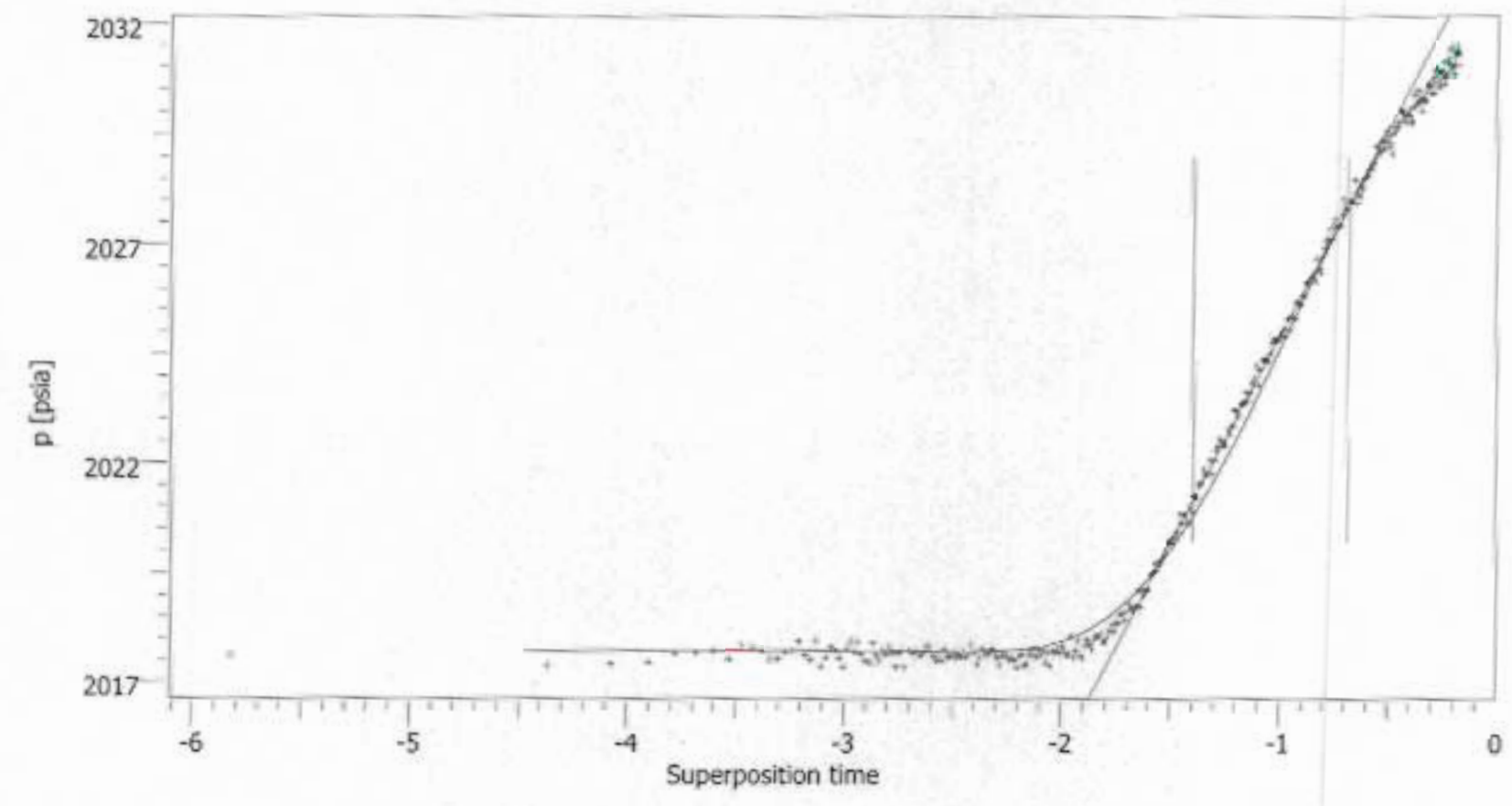

Pressure build-up $\# 1$

Rate 0 STB/D

Rate change 59310 STB/D

P@odt $=0 \quad 2017.7$ psia

Pi 2031.28 psia

Smoothing 0.5

Prod. Index 4369.39 [STB/D]/psia

Selected Model

Model Option Standard Model

Well Line source

Reservoir Two porosity PSS

Boundary One fault

Main Model Parameters

TMatch $0.178[\mathrm{hr}]-1$

PMatch 0.0892 [psia]-1

Phi 0.0316

Phi.h $31.6 \mathrm{ft}$

k.h, total $1.6164 E+5$ md.ft

$k$, average 161.64 md

Pi 2031.28 psia

Well distance $2360 \mathrm{ft}$
Model Parameters

Reservoir \& Boundary parameters

Pi 2031.28 psia

k.h $1.6164 E+5$ md.f

k 151.64 md

Phi 0.0316

Phi.h $31.6 \mathrm{ft}$

Omega 0.0392

Lambda $5.4 E-5$

L- Constant P. $4540 \mathrm{ft}$

Derived \& Secondary Parameters

Semilog Line (Pressure build-up \#1)

From $77.7139 \mathrm{hr}$

To $93.3028 \mathrm{hr}$

Slope 9.45073 psi

Intercept $2034.31 \mathrm{psia}$

P@1hr 2017 psia

PMatch 0.122 [psia]-1

k.h $2.2057 \mathrm{E}+5 \mathrm{md}$.ft

k 220.57 md

$p^{*} \quad 2034.31$ psia

Phi 0.0201 


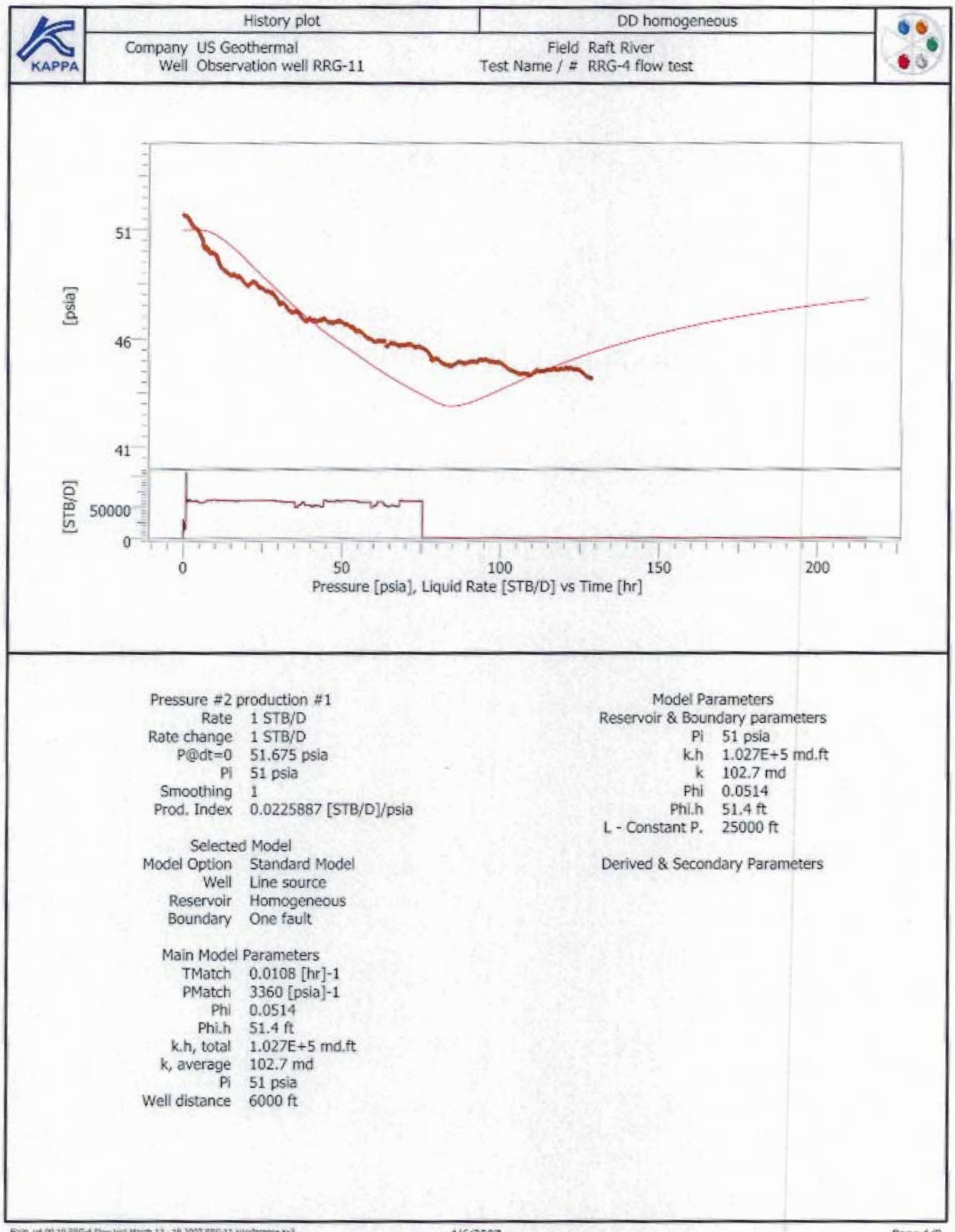

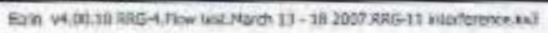




\begin{tabular}{|c|c|c|c|}
\hline \multirow{2}{*}{$\sum_{\text {KAPPA }}$} & Log-Log plot & DD homogeneous & \multirow{2}{*}{$\begin{array}{l}08 \\
0\end{array}$} \\
\hline & $\begin{array}{l}\text { Company US Geothermal } \\
\text { Well Observation well RRG-11 }\end{array}$ & $\begin{array}{l}\text { Field Raft River } \\
\text { Test Name / \# RRG-4 flow test }\end{array}$ & \\
\hline
\end{tabular}

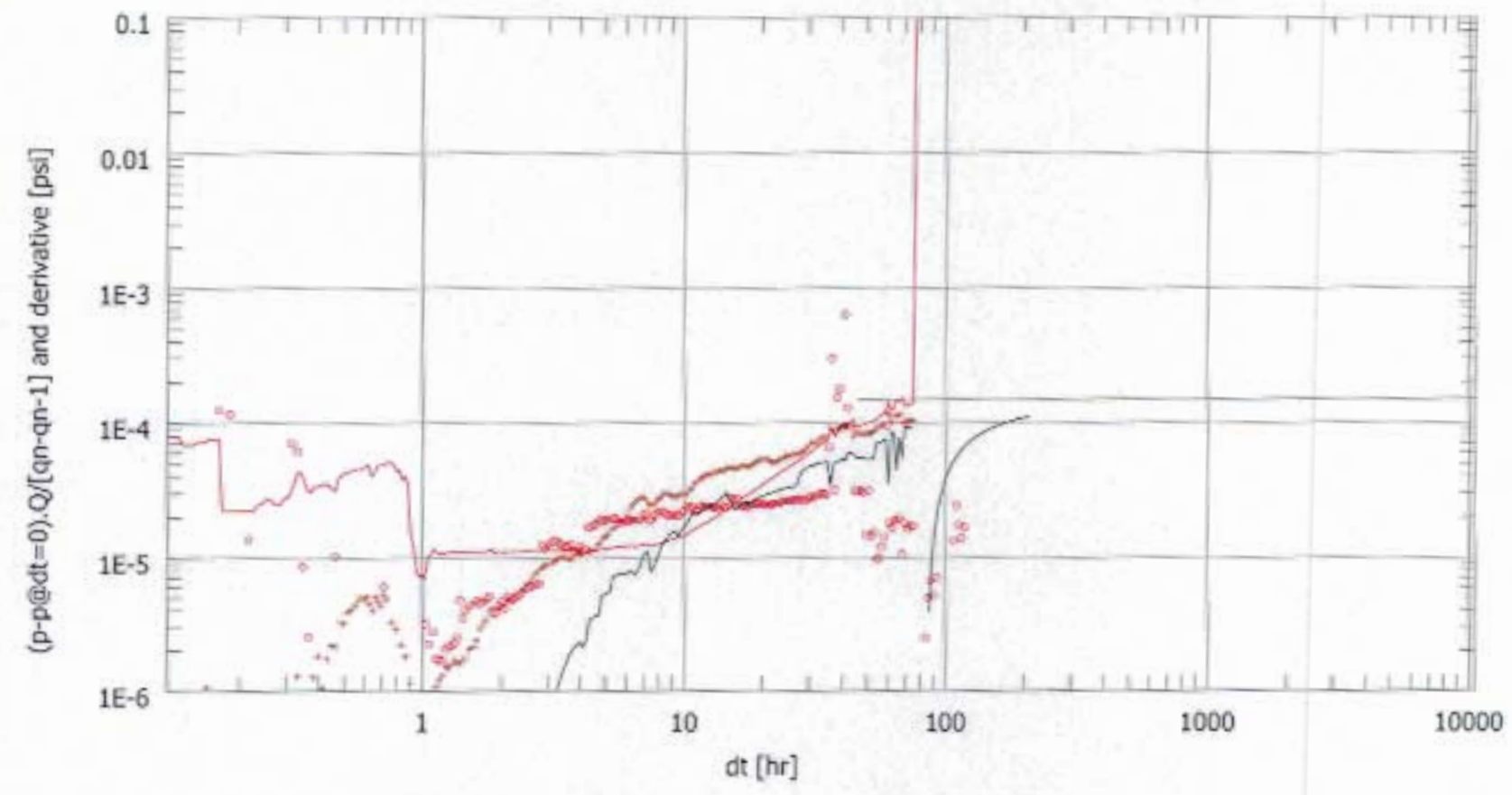

Pressure \#2 production \#1

Rate 1 STB/D

Rate change 1 STB/D

$P @ d t=0 \quad 51.675$ psia

Pi 51 psia

Smoothing 1

Prod. Index 0.0225887 [STB/D]/psia

Selected Model

Model Option Standard Model

Well Line source

Reservoir Homogeneous

Boundary One fault

Main Model Parameters

TMatch $0.0108[\mathrm{hr}]-1$

PMatch 3360 [psia]-1

Phi 0.0514

Phi,h $51.4 \mathrm{ft}$

k.h, total $1,027 \mathrm{E}+5$ md.ft

$k$, average $102.7 \mathrm{md}$

Pi 51 psia

Well distance $6000 \mathrm{ft}$
Model Parameters

Reservoir \& Boundary parameters

Pi 51 psia

k.h $1.027 \mathrm{E}+5 \mathrm{md} . \mathrm{ft}$

k. $102.7 \mathrm{md}$

Phi 0.0514

Phith $51.4 \mathrm{ft}$

L - Constant P. $\quad 25000 \mathrm{ft}$

Derived \& Secondary Parameters 


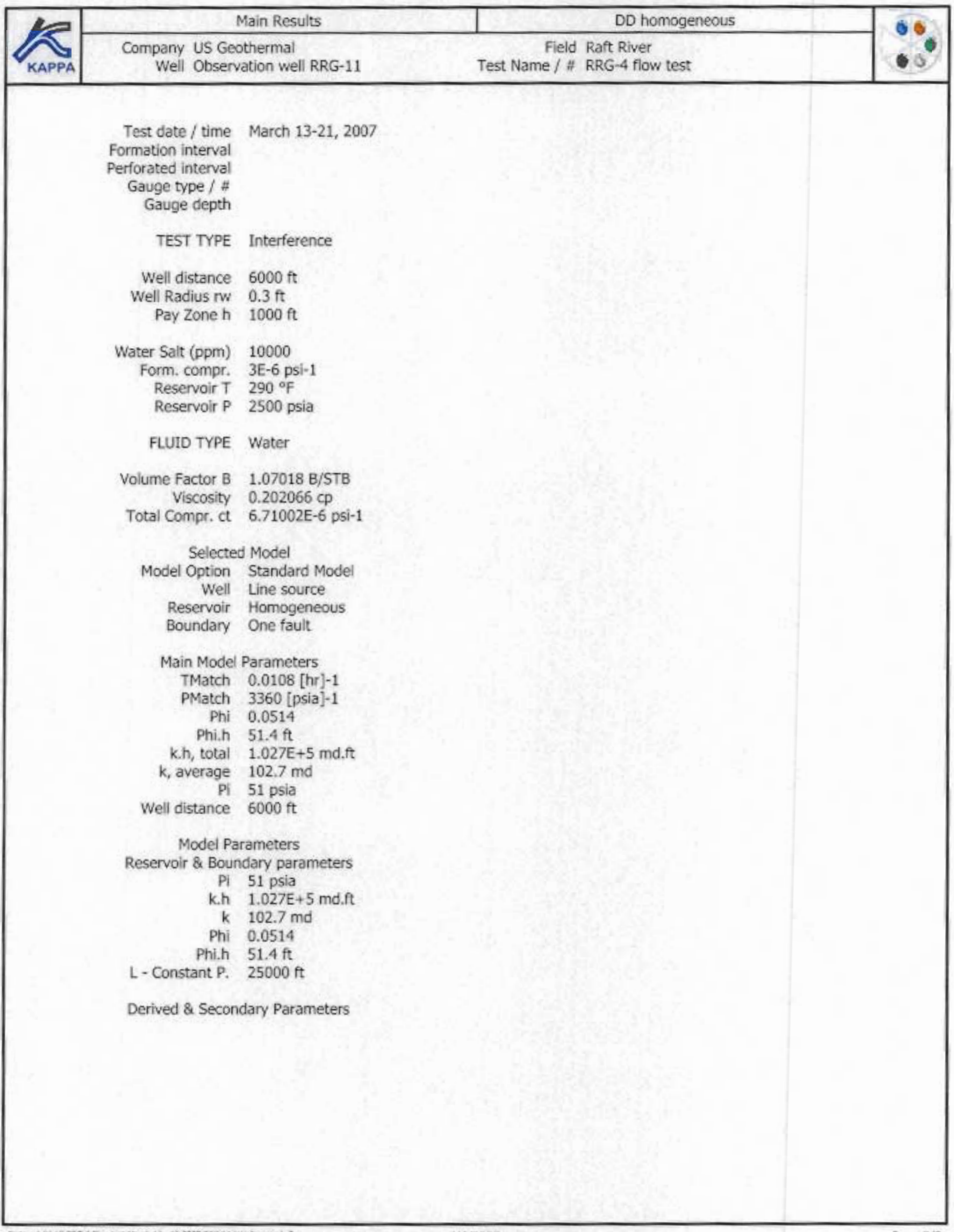




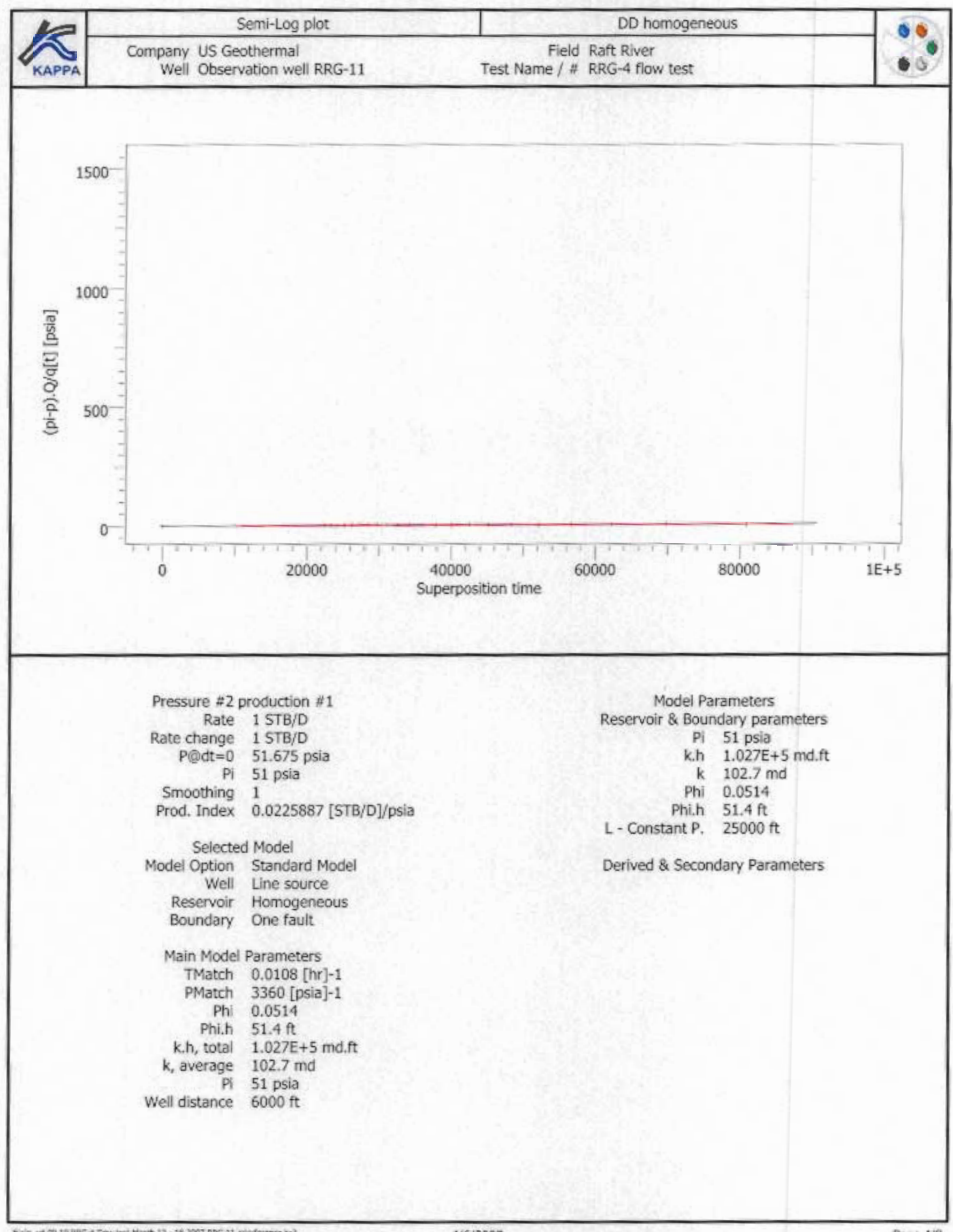




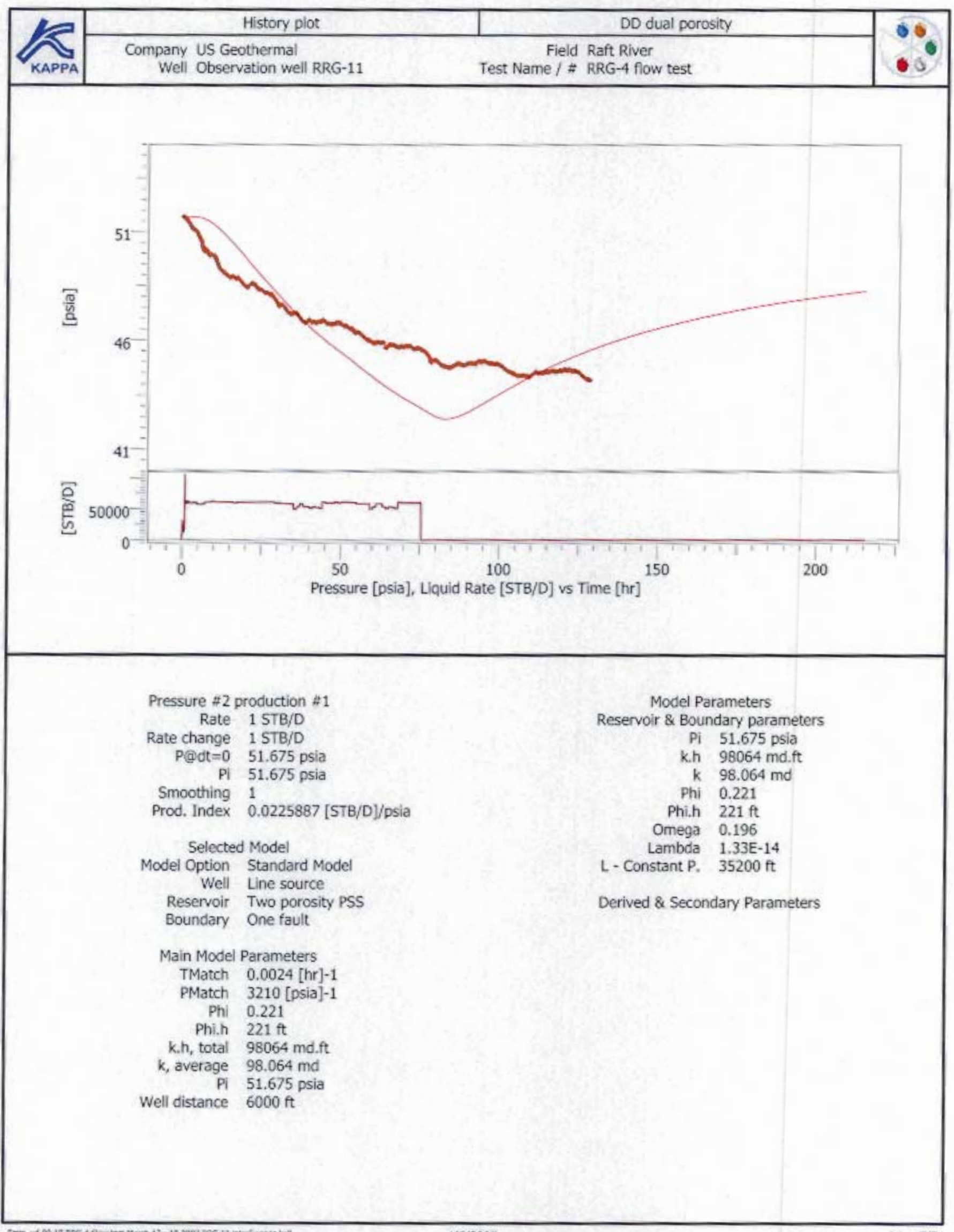




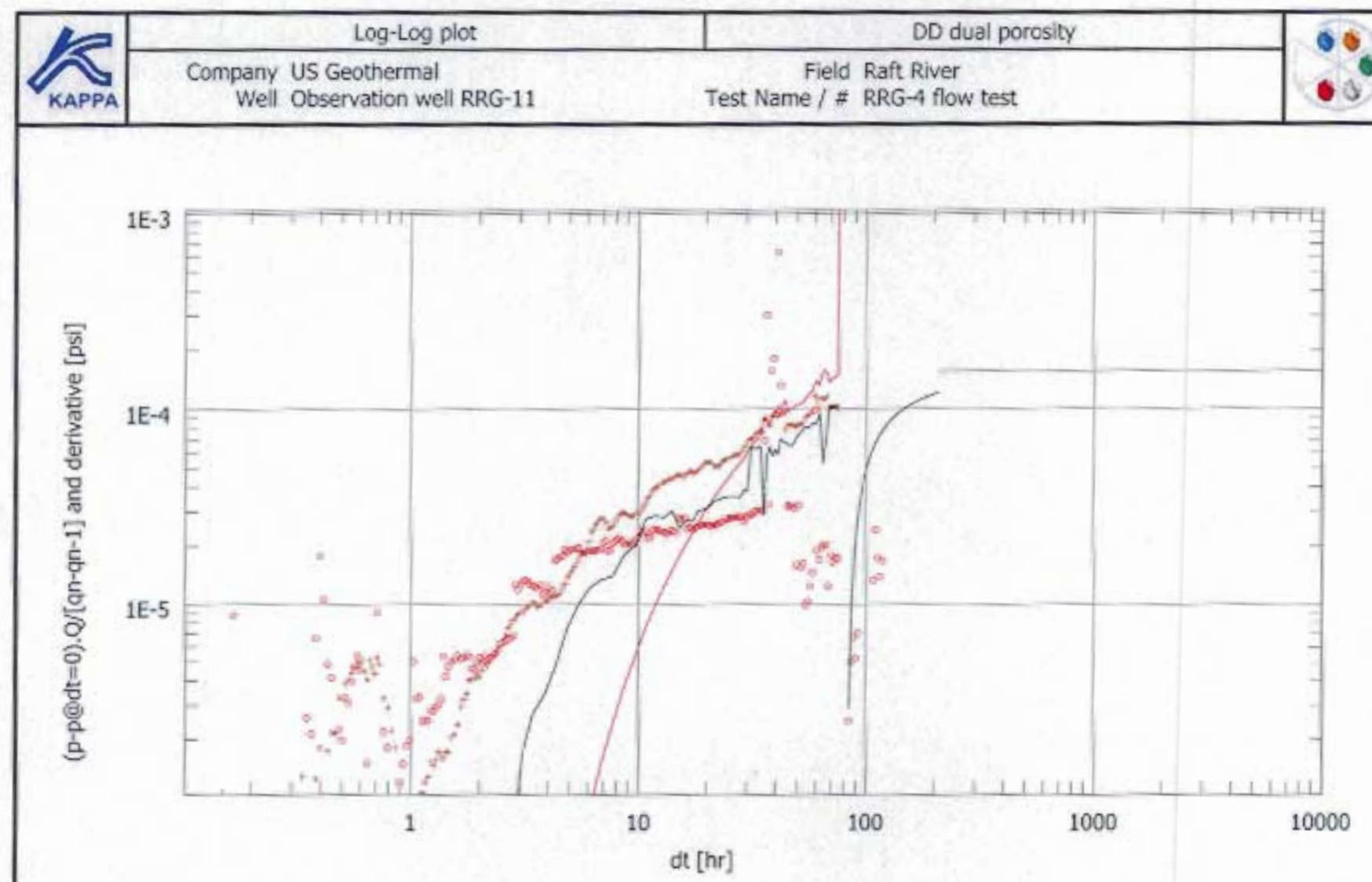

Pressure $\# 2$ production \#1

Rate 1 STB/D

Rate change $15 T B / D$

$P @ d t=0 \quad 51.675 \mathrm{psia}$

Pi 51.675 psia

Smoothing 1

Prod. Index 0.0225887 [STB/D]/psia

Selected Model

Model Option Standard Model

Well Line source

Reservoir Two porosity PSS

Boundary One fault

Main Model Parameters

TMatch $0.0024[\mathrm{hr}]-1$

PMatch 3210 [psia]-1

Phi 0.221

Phi.h $221 \mathrm{ft}$

k.h, totat 98064 md.ft

$k$, average $98.064 \mathrm{md}$

Pi 51.675 psia

Well distance $6000 \mathrm{ft}$
Model Parameters

Reservoir \& Boundary parameters

Pi 51.675 psia

k.h 98064 md.ft

k 98.064 md

Phi 0.221

Phi.h $221 \mathrm{ft}$

Omega 0.196

Lambda 1.33E-14

L - Constant P. $\quad 35200 \mathrm{ft}$

Derived \& Secondary Parameters 


\begin{tabular}{|c|c|c|c|}
\hline \multirow{2}{*}{\begin{tabular}{|c|c|} 
KAPPA \\
\cline { 2 - 4 }
\end{tabular}} & $\begin{array}{c}\text { Main Results } \\
\text { Company US Geothermal } \\
\text { Well Observation well RRG-11 }\end{array}$ & To dual porosity \\
\hline
\end{tabular}

Test date / time Formation interval Perforated interval Gauge type / \# Gauge depth

March 13-21, 2007

TEST TYPE Interference

Well distance $6000 \mathrm{ft}$ Well Radius rw $0.3 \mathrm{ft}$

Pay Zone h $1000 \mathrm{ft}$

Water Salt (ppm) 10000

Form. compr. 3E-6 psi-1

Reservoir T $290^{\circ} \mathrm{F}$

Reservoir P 2500 psia

FLUID TYPE Water

Volume Factor B $1.07018 \mathrm{~B} / \mathrm{STB}$

Viscosity $0.202066 \mathrm{cp}$

Total Compr, ct $\quad 6.71002 \mathrm{E}-6 \mathrm{psi}-1$

Selected Model

Model Option Standard Model

Well Line source

Reservoir Two porosity PSS

Boundary One fault

Main Model Parameters

TMatch $0.0024[\mathrm{hr}]-1$

PMatch 3210 [psia]-1

Phi 0.221

Phi.h $221 \mathrm{ft}$

k.h, total 98064 md.ft

k, average 98.064 md

Pi 51.675 psia

Well distance $6000 \mathrm{ft}$

Model Parameters

Reservoir \& Boundary parameters

Pi 51.675 psia

k.h 98064 md.ft

k 98.064 md

Phi 0.221

Phi.h $221 \mathrm{ft}$

Omega 0.196

Lambda $1.33 E-14$

L - Constant P. $\quad 35200 \mathrm{ft}$

Derived \& Secondary Parameters 


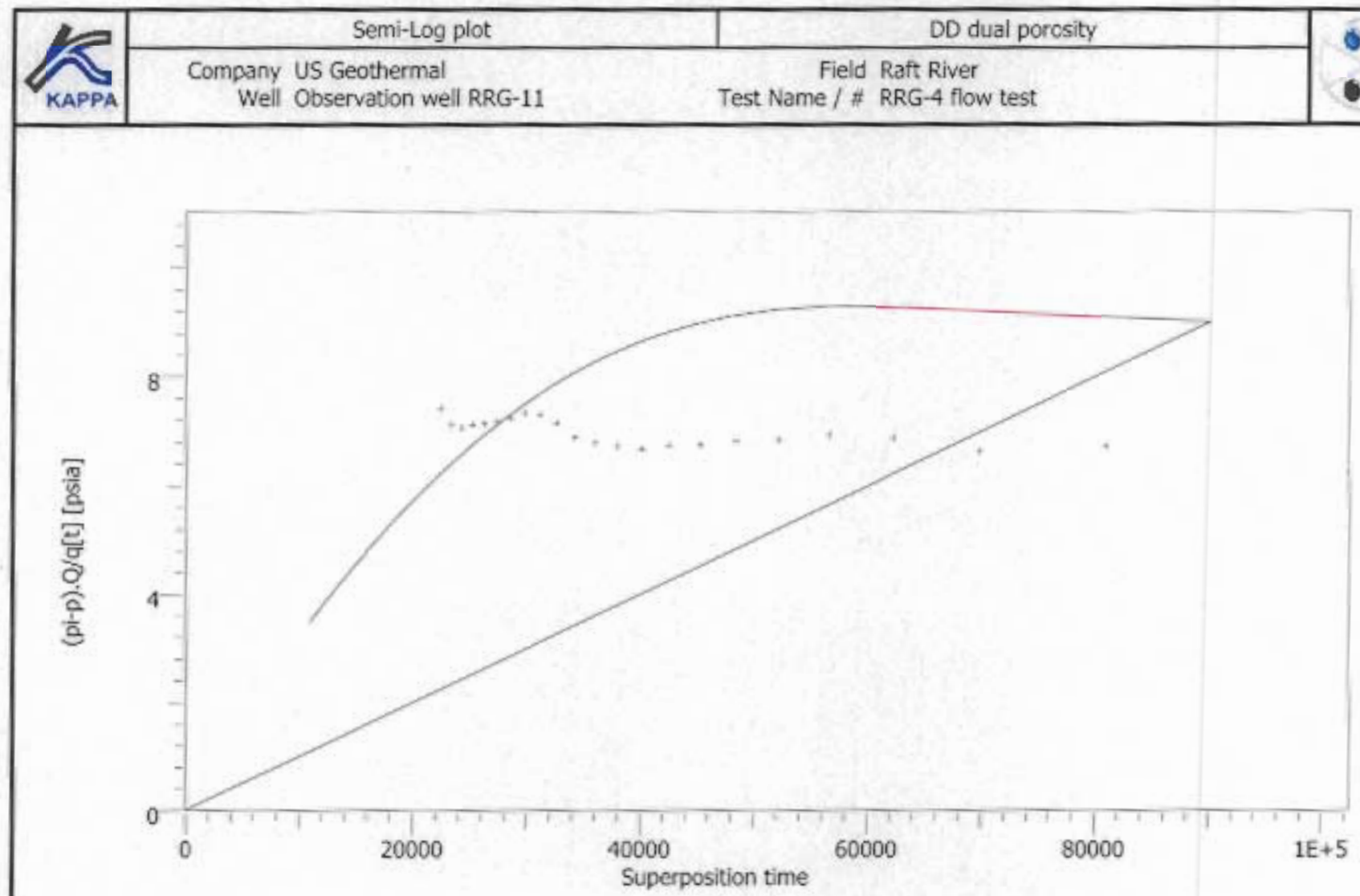

Pressure $\# 2$ production \#1

Rate $1 \mathrm{STB} / \mathrm{D}$

Rate change 1 STB/D

$P @ d t=0 \quad 51.675$ psia

Pi 51.675 psia

Smoothing 1

Prod. Index 0.0225887 [STB/D]/psia

Selected Model

Model Option Standard Model

Well Line source

Reservoir Two porosity P5S

Boundary One fault

Main Model Parameters

TMatch $0.0024[\mathrm{hr}]-1$

PMatch 3210 [psia]-1

Phi 0.221

Phi.h $221 \mathrm{ft}$

k.h, total 98064 md.ft

$k$, average $98.064 \mathrm{md}$

Pi 51.675 psia

Well distance $6000 \mathrm{ft}$
Model Parameters

Reservoir \& Boundary parameters

Pi 51.675 psia

k.h 98064 md.ft

k 98.064 md

Phi 0.221

Phi.h $221 \mathrm{ft}$

Omega 0.196

Lambda $1.33 \mathrm{E}-14$

L- Constant P. $35200 \mathrm{ft}$

Derived \& Secondary Parameters 